OCCIDENTALIST PERCEPTIONS

OF EUROPEAN ARCHITECTURE IN

NINETEENTH-CENTURY PERSIAN

TRAVEL DIARIES

Travels in Farangi Space

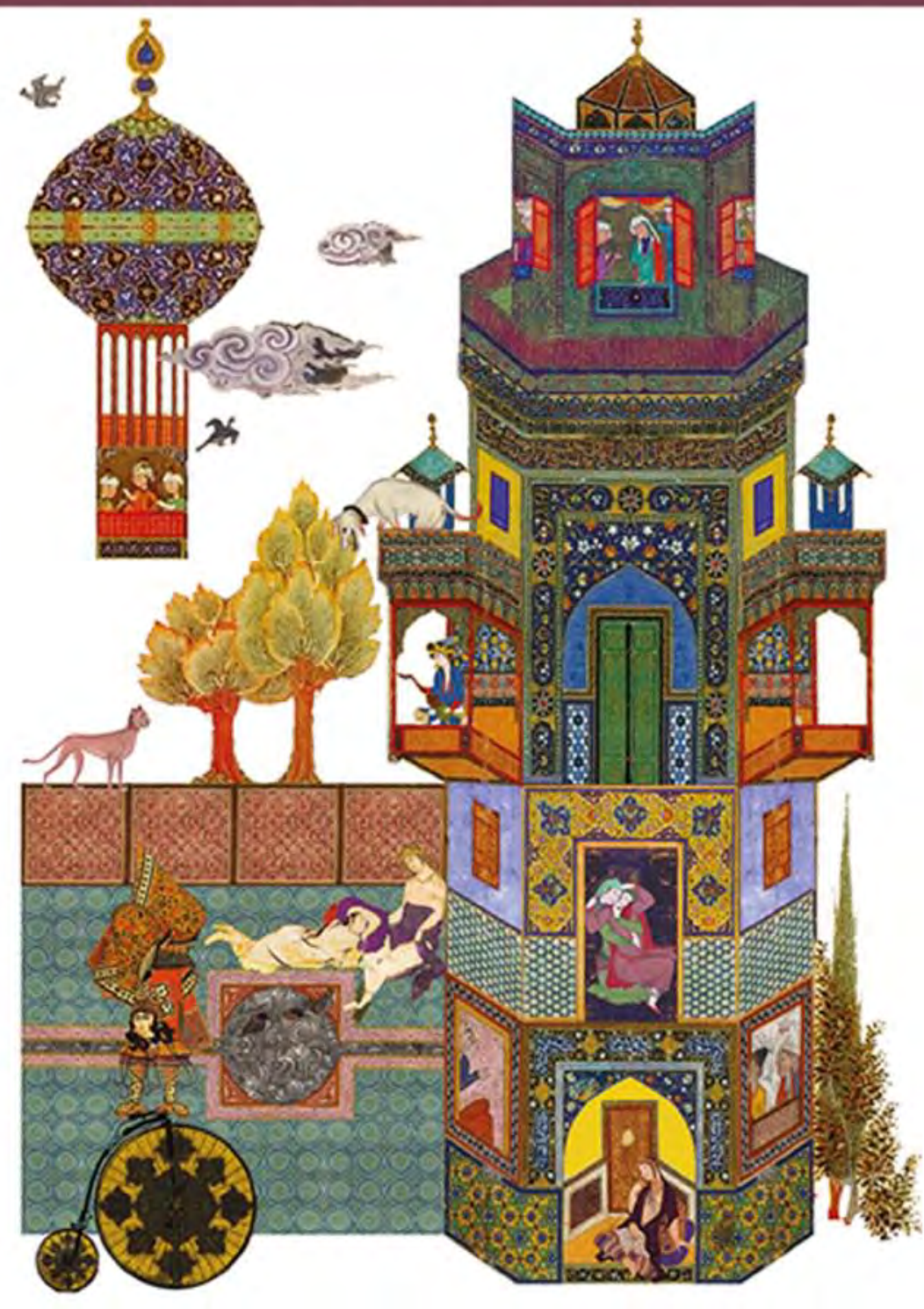

Vahid Vahdat 


\section{Occidentalist Perceptions of European Architecture in Nineteenth-Century Persian Travel Diaries}

In the midst of Europe's nineteenth-century industrial revolution, four men embarked on separate journeys to the wondrous Farangestan - a land of fascinating objects, mysterious technologies, heavenly women, and magical spaces. Determined to learn the secret of Farangestan's advancements, the travelers kept detailed records of their observations. These diaries mapped an aspirational path to progress for curious Iranian audiences who were eager to change the course of history. Two hundred years later, Travels in Farangi space unpacks these writings to reveal a challenging new interpretation of Iran's experience of modernity.

This book opens the Persian travelers' long-forgotten suitcases, and analyzes the descriptions contained within to gain insight into Occidentalist perspectives on modern Europe. By carefully tracing the physical and mental journeys of these travelers, the book paints a picture of European architecture that is nothing like what one would expect.

Vahid Vahdat is an architect, urban designer, and historian of architecture and urban form. His primary field of research is the theory and history of modern architecture and urban space, with an emphasis on non-Western experiences of modernity. 


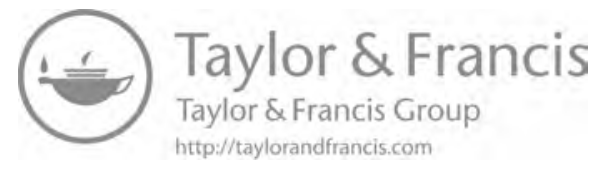




\section{Occidentalist Perceptions of European Architecture in Nineteenth-Century Persian Travel Diaries}

Travels in Farangi Space

\section{Vahid Vahdat}


First published 2017

by Routledge

2 Park Square, Milton Park, Abingdon, Oxon OX14 4RN

and by Routledge

711 Third Avenue, New York, NY 10017

Routledge is an imprint of the Taylor \& Francis Group, an informa business

\section{(C) 2017 Vahid Vahdat}

The right of Vahid Vahdat to be identified as author of this work has been asserted by him in accordance with sections 77 and 78 of the Copyright, Designs and Patents Act 1988.

All rights reserved. No part of this book may be reprinted or reproduced or utilised in any form or by any electronic, mechanical, or other means, now known or hereafter invented, including photocopying and recording, or in any information storage or retrieval system, without permission in writing from the publishers.

Trademark notice: Product or corporate names may be trademarks or registered trademarks, and are used only for identification and explanation without intent to infringe.

British Library Cataloguing-in-Publication Data

A catalogue record for this book is available from the British Library

Library of Congress Cataloging-in-Publication Data

Names: Vahdat, Vahid, author.

Title: Occidentalist perceptions of European architecture in nineteenth-century Persian travel diaries : travels in farangi space / Vahid Vahdat.

Description: New York : Routledge, 2017. I Based on the author's thesis (doctoral-Texas A \& M University, 2014) under the title: Imagining the modern : an Occidentalist perception and representation of farangi architecture and urbanism in 19th-Century Persian travel diaries. I Includes bibliographical references and index.

Identifiers: LCCN 2016037864 I ISBN 9781472473943 (hardback : alk. paper) I ISBN 9781315547510 (ebook)

Subjects: LCSH: Space (Architecture)-Europe-Foreign public opinion, Iranian. I Europe-Civilization-19th century. I East and West. I Travelers' writings, Persian-19th century-History and criticism. | Iranians-Travel-Europe-History-19th century. | Iranians-Diaries. I Iran-Intellectual life-19th century.

Classification: LCC NA2765 .V34 2017 I DDC 720.94/09034—dc23

LC record available at https://lccn.loc.gov/2016037864

ISBN: 9781472473943 (hbk)

ISBN: 9781315547510 (ebk)

Typeset in Sabon

by Apex CoVantage, LLC 


\section{Contents}

Acknowledgments vii

A note on the text viii

List of figures ix

1 The first brick 1

Prologue 1

Modernity, distorted 3

The inception of modernity in Iran 5

The research odyssey 8

A cross section through the book 9

Notes 10

References 12

2 Modernity in a suitcase

Innocents abroad 14

Abolhasan 15

Mirza Saleh 21

Rezaqoli 27

Farrokh-Khan 31

Modernity as a souvenir 35

Notes 39

References 43

3 When worlds collide

Verbalizing space 46

Quantifying space 49

Journey from the center of the earth 51

Farangestan as a wonderland 57

Virtual realities 60 
vi Contents

Representing the representation 63

The reincarnated image 68

Notes 71

References 75

4 Imagining the modern

Mapping modernity 78

A kucheh-bagh to progress 80

Refashioning the Farangi house 82

Rediscovering Eram 85

Reflecting a different sky 89

The kingly palace 91

The bridal chamber 94

The nightless city 98

Space that belongs to nobody 102

Touching the Milky Way 108

Constructing the magical 110

Aesthetics of rationality 114

Spatial lacunae 115

Notes 121

References 133

5 Tajaddod as a discourse

League of extraordinary gentlemen 135

Building the future 140

Epilogue 144

Notes 146

References 148

Appendix A: Abolhasan's itinerary

Appendix B: Mirza Saleh's itinerary

Appendix C: Rezaqoli's itinerary

Appendix D: Farrokh-Khan's itinerary

Glossary

Bibliography

Index 


\section{Acknowledgments}

Books, like architectural projects, are the culmination of many individual efforts. They cannot be constructed without a great deal of assistance and support. During the course of my research I have been accompanied by many colleagues whose enthusiasm and encouragement made the adventure enjoyable and fruitful. I would like to extend my profound gratitude to my doctoral advisors at Texas A\&M University, Robert Warden and Peter Lang, for their unflagging support and advice during the early stages of this work. I am also sincerely grateful to Rola el-Husseini, whose guidance grounded my exploration, as well as my other doctoral committee members, Mohammad Ghanoonparvar and Michael Neuman. Thank you for providing me with a strong foundation on which to build.

This study has enjoyed generous fellowship support from the Melbern G. Glasscock Center for Humanities Research at Texas A\&M University. I would like to extend my thanks to the staff of the center, who graciously supported me during my year-long residency. I am also indebted to the Office of Graduate Studies at Texas A\&M for providing a dissertation fellowship that helped to sustain my work during parts of its extensive writing period. Finally, I would like to thank the staff and management of the Texas A\&M University Library and the University Writing Center for their amazing services, and particularly Thadeus Bowerman, whose editorial work has greatly enriched the work. I am also indebted to my professional editor Jesse L. Rester, for his valuable inputs.

Many colleagues and friends provided advice on the book during the several stages of its draft. Farshid Emami, Ahmad Ashraf, Mohammad Gharipour, and Shima Mohajeri deserve my gratitude for their advice. This book would not have been possible without the support and encouragement of my friends and my family. I thank my wife, a creative architect, my mother, a passionate historian, and my father, a principled academician, who have been instrumental in the formation of this book as well as my interest in the topic. 


\section{A note on the text}

The Persian terms that appear in this book generally follow the transliteration system laid out by Nasser Sharifi in his Cataloging of Persian Works, except in the following cases: (1) for historical figures and places, I have kept the most commonly accepted English spellings, (2) for quotes from English sources, I have used the authors' preferred spelling, and (3) because different consonants are pronounced alike in Persian, I have avoided diacritical marks, except for 'ayn and hamza.

I have been fortunate that among the four travel diaries that I have analyzed, two have been already translated to English. When directly quoting from the diaries, I have used the already-translated material, so the reader will have the opportunity to easily refer to the books for additional information. In most other cases, I have used the original Persian diaries. In general, all the translations from Persian are mine, unless otherwise indicated. As a Persian reader of these travel diaries, 150 years after they were written, I have tried to maintain the original quality of the language and to faithfully represent the documents in my translations. 


\section{Figures}

2.1 An 1823 sculpture of Mirza Saleh by Robert William Sievier. 22

2.2 From left to right, Rezaqoli Mirza, Teymur Mirza, and Vali. Drawing by John Partridge, July 1836.

2.3 Farrokh-Khan Aminoddowleh, engraved in 1857 from a Persian miniature.

3.1 Vauxhall Gardens was a great source of wonder to the traveler, as they enthusiastically describe its symmetrical paths, lighting features, and public mingling of men and women.

3.2 Iran's booth at the 1851 Great Exhibition in the Crystal Palace.

4.1 The Charbagh of Isfahan, an expansive version of the kucheh-bagh, was designed by Sheykh Baha'i in the early seventeenth century.

4.2 A view of the east nave of the Crystal Palace, showing the Persian booth in the bottom left corner.

4.3 Gustave Doré's illustration of a crowded London street, for London: A Pilgrimage, published in 1872. The dense urban crowding of the city was sometimes described by Abolhasan as oppressive and stifling.

4.4 The travelers remain silent about the challenging urban conditions of the working-class quarters in major industrial cities of Europe, such as London.

Plate 1 Mother and child, attributed to Muhammad Hasan, second or third decade of the 19th century.

Plate 2 An 1800 map showing Abolhasan's course of travel. The blue lines show sea routes and the red lines show land trips.

Plate 3 The Anniversary Meeting of the Charity Children in the Cathedral of St. Paul, painted by Robert Havell, Jr. in 1826.

Plate 4 Mirza Abu'l Hassan Khan (Abolhasan) holding a book, painting by Sir William Beechey. 
Plate 5 An 1823 map showing Mirza Saleh's course of travel. The blue lines show sea routes and the red lines show land trips.

Plate 6 An 1839 map showing Rezaqoli's course of travel. The blue lines show sea routes and the red lines show land trips.

Plate 7 An 1847 map showing Farrokh-khan's course of travel. The red lines show railroads, the blue lines show sea routes, the green lines show land trips, and the dashed black lines represent unknown mode of travel.

Plate 8 Naseraddin Shah's watercolor painting of Farangi Architecture.

Plate 9 A mid-nineteenth-century view of St. Paul's Cathedral, by Thomas Hosmer Shepherd. St. Paul's Cathedral was a common attraction for all four travelers who admired its magnitude, structure, acoustics, and ornament.

Plate 10 Salisbury Cathedral was a source of wonder to Mirza Saleh for having the tallest church spire in England. Salisbury Cathedral Seen from the Bishop's Grounds, 1821-22 by John Constable (Oil on canvas, $89 \times 114$ cm Inv. 204 P).

Plate 11 Example of public/private divisions and central interior courtyards in Persian architecture. Gerami House, Yazd, Iran.

Plate 12 Astley's Amphitheatre from Rudolph Ackermann's 1808-1810 Microcosm of London. Abolhasan referred to Astley's Amphitheatre as "horse-opera" and Rezaqoli found it heavenly.

Plate 13 Menai Suspension Bridge was designed by Thomas Telford in 1826 to connect the mainland of Wales to the island of Anglesey. Farrokh-Khan considered the bridge as one of the greatest technological achievements of his time.

Plate 14 Westminster Hall in London by Augustus Pugin. Mirza Saleh found the absence of central supporting columns in the building to be a curious and inexplicable wonder.

Plate 15 Timcheh-ye Aminoddowleh at the Kashan bazaar. The soaring construction of the building was supervised by Farrokh-Khan Aminoddowleh.

Plate 16 The multi-story Farangi building stands in the background of Naseraddin Shah's painting. 


\section{The first brick}

\section{Prologue}

Nader: "Let her give me one reason, why in this situation we should leave for abroad."

Simin: "Show me a good reason why we should stay."

Nader: "I'll give you a thousand reasons."

Simin: "Tell me just one."

Nader: "My dad. I can't leave him. Do I need to give more?”. . . .

Simin: "He's using this reason as an excuse right now: his father."

Nader: "I didn't use it as an excuse."

Simin: "His father is suffering from Alzheimer's. He's not aware that he is his son. Or who's around him. What difference does it make to him? Whether it's you or someone else?"

Nader: "Why do you say that? It matters."

Simin: "Does he understand that you're his son?"

Nader: "But I know he is my father."

Simin: "Is your daughter not important to you? Her future is not important to you?"

Nader: "Who said this is about our daughter? Why do you think it's only important to you? All these other children living in this country, do none of them have a future?"

This opening dialogue of Asghar Farhadi's Oscar-winning film, A Separation, portrays the dilemma of the Iranian consciousness as it struggles between the weight of tradition and the aspiration toward a modern future. In the film, Simin has filed for divorce after fourteen years of marriage, citing Nader's resistance to their initial plan to live abroad. The dialogue occurs in the courtroom while the camera is situated in the judge's seat, placing the audience in the position of adjudicating the dispute. The film confronts us with what Darius Shayegan has described as a schizophrenic mentality in Iran. ${ }^{1}$ Simin can be seen as representing the desire for progress through her aspiration to seek better opportunities for her daughter in the 


\section{The first brick}

Canada, while Nader feels an intense duty to stay and care for his ailing father, who is afflicted with Alzheimer's disease. Both Simin and Nader are prepared to make a sacrifice, either by leaving the past behind or by abandoning the prospect of future advancement, respectively. Simin suggests that a progressive future cannot be had without cutting one's ties to the constraining past. Nader, in contrast, holds that some traditional values should not be compromised. He argues that the past, represented in the character of the father, is an extension of his present, and that any form of progress has a duty to acknowledge its history. Although the conflict between the generations helps explain the tension between the past and the future, it leaves us with many unanswered questions for Simin, including:

- Do all the roads to progress pass through the West?

- Do we not have any responsibility in regard to our history?

- Are we morally allowed to simply leave our past behind?

The elderly father in this film, who was once young and striving, can no longer control his bodily functions. He represents a historical attachment, either to the great Persian Empire or to the golden age of Islamic civilization. This constructed historical identity, similar to the degraded memory of the father who is unable to recognize his son, is alienated from its contemporary condition. The inevitable tragedy of the film is caused by the father's quixotic quest to purchase a newspaper. This failed attempt to connect to the present poses serious questions for Nader, including:

- Except for urinating all over their lives, what is this father doing for the family?

- How real is the concept of the glorious past?

- Are the remnants of the past morally allowed to preempt our aspirations toward progress?

While the director leaves these questions open, he makes it clear that "a separation" is inevitable.

My own engagement with the questions of modernity and tradition in Iran began with my studies in architecture at Yazd University. Exploring the historic fabric of the city of Yazd exposed me to an accretion of architectural experiences built up through centuries of local practice. The traditional wisdom embedded in this city has over countless generations created a dynamic and organic architecture that functions harmoniously with the surrounding natural environment. After being struck by an exterior phenomenon during the last century, however, this traditional architecture seemed to have gone into a coma, becoming rigid and setting into decay. Some critics label this phenomenon "modernity" and believe that Iran's architectural heritage will not recover from the coma. 


\section{Modernity, distorted}

"When the me'mar [mason, and later architect] lays the first brick crookedly, the wall goes crookedly on up to the Pleiades."

This Persian proverb reveals the mentality behind architectural practice in Iran, which is stuck between a long history of traditional experience and what modernity has to offer. Architects know that every abstract line they draw on a tracing paper, or every rasterized shape they render on their screens, will affect real lives. This awareness of the social and cultural significance of design may paralyze architects and planners. To lay "the first brick," it is necessary to set a balanced theoretical foundation on the unstable ground between tradition and modernity. This is critical for architects and planners; failing in this intellectual project can lead to disaster. An extreme example of such failure can be seen in the story of Mohamed Atta, who studied architecture at Cairo University and urban planning at Hamburg University of Technology. Atta understood the contemporary architectural developments of his homeland as "haphazard attempts to modernize" the Middle East. In his Master's thesis, he criticized the imposition of modern high-rise buildings as a Western attempt to penetrate into the virgin urban fabric of Islamic cities. His outrage toward such "shameless embrace of the West" ${ }^{2}$ showed itself several years later, when Atta plotted the September 11 attacks and personally piloted a plane into the World Trade Center.

Such theoretical traumas and ideological conflicts, if not addressed properly, can burst into horrifying tragedies. The central impetus for this book's investigation is to approach this conflict by readdressing the following questions:

- Is modernity totally alien to Iran's past?

- Is modernity essentially irreconcilable with non-Western traditions?

- Is a tragic separation truly unavoidable?

The struggle to theorize the relationship between traditional values and modernity is an ongoing intellectual project, and it has been the subject of many scholarly works published in Iran since the 1850 s. $^{3}$ Recent international scholarship tends to unsettle the long-standing assumption that modernism arose via a one-way diffusion from the European cultural "center" to the global periphery (or from the European original to the Middle Eastern copy). Many Iranian critics of modernity, however, still rely on a strict equation of modernization with Westernization. Assuming that modernity is by nature a product of Occidental rationality, they see it as text, written in the context of the socioeconomic history of Europe, and conclude that any attempt to rewrite modernity is at best a slavish attempt at imitation or an "arbitrary and unsystematic copying from Europe." 


\section{The first brick}

These perspectives de-historicize modernity and insist on viewing Iranian and European societies as non-contemporaneous. Locating "the West" as a temporal destination for non-Western societies is only a logical outcome of a mentality that Hisham Sharabi rightfully calls the "model-oriented consciousness." 5 The model-oriented consciousness positions European modernity as an archetypal model for its non-original copies. Such idealistic renderings of European modernity tend to disparage local modernities as being distorted, altered, deformed, inauthentic, and false. This distrust in the originality of non-European modernities explains the abundance of pathological metaphors in the literature on modernity in Iran, where local interpretations of modern architecture are frequently portrayed with the rhetoric of disease: "genesis amnesia," "cultural schizophrenia," "plagued by the West," "melancholy," "apoplexy," and "paralysis." Commentators who adopt this approach inevitably conclude with a diagnosis of an ill-formed and derivative modernity that has come to afflict Iran.

In this book, I have sought to shed light on the local origins of the Iranian experience of modernity. In doing so, I have been cautious to avoid any essentializing positions and to refrain from any prescriptive outlooks. The methodology that I adopt to make my case should also satisfy those critics that insist on a European origin for non-Western modernities. If nonWestern modernities result from a hegemonic transfer from the West, then the cause of its so-called distortion must rest somewhere in the routes that modernity takes in transit. Talinn Grigor suggested a possible explanation for this phenomenon:

The fact that the duplication of Western ... motifs seems always a bit off the mark owes as much to the technique of their transference and means of reproduction as to intentional aesthetic choices. It is worth noting, too, that most of the examples analyzed here were duplicated either from memory by those who had returned from Europe ... or from photographs and etchings. ${ }^{7}$

My method in approaching the bits that seem "off the mark" in Iran's experience of modernity is through the study of its "transference." I study "those who had returned from Europe" as a means to understand the complex subjective mentality that underlies the Iranian experience of modernity. By looking at Iranian evaluations of European architecture in travel accounts from the nineteenth century, I argue in this book that the route modern architecture takes from Europe to Iran is a mental journey between the Iranian self and a pre-imagined Other. This notion of Otherness plays an important role in my analysis and, as a theoretical concept, it situates my research within the context of postcolonial literature. Edward Said has famously invoked this notion of Otherness to discuss Orientalism as a selfdefining project for the modern West. In his view, Westerners, at the center of a power relationship, have tended to construct an imagined Other in the 
Orient, colored by exotic fantasies, rendered with romantic memories, and filtered by colonial interests. ${ }^{8}$

My study differs from Said's in two ways. First, I have deliberately ignored the operation of geopolitical power in the Othering process. Although this might appear to be a striking methodological choice that effaces vital context, I believe that it can allow for a clearer focus on previously unexamined aspects of East/West relationships. Often, the more nuanced, unexpected, and intersectional aspects of power and identity can become overwhelmed in analyses of the global political context. By bracketing that context, the true complexity of fantasy - which has often been ignored under the shadow of colonial analysis - can emerge and reveal its diverse inspirations. The choice to avoid a discussion of the global power structure is by no means an attempt to justify colonial ambitions, nor is it a denial of the asymmetrical relationship between the colonized and the colonizer. It is intended rather to create space for us to appreciate the stimulating aesthetic qualities of imaginary cultures, haunted landscapes, exotic beings, mystical objects, mythical ideas, sensual scenes, sublime imagery, erotic desires, and magical memories. ${ }^{9}$

Second, while I draw strongly on Said's explanation of how Othering creates a distorted imagery, in this book I have changed the direction of the gaze. Here, I describe the Iranian observer who constructs a vision of modernity based on "Occidentalist" fantasies. In this approach, I am indebted to a handful of scholars, such as Sadik Jalal al-Azm and Hasan Hanafi, who have established foundational methodologies for studying images of the West as perceived by non-Western observers. ${ }^{10}$

An example of this kind of Occidentalist fantasy of exotic imaginary Western subjects can be seen in the miniature paintings of European Women produced in Iran during the nineteenth century. The illustration in Plate 1, for example, combines traditional Iranian aesthetics of feminine beauty - a rounded, doe-eyed countenance, thick brows nearly meeting above the nose, small delicate lips, a mole on the cheek, and long black hair - with the exotic and eroticized attributes projected onto the Western Other, including the subject's seductively half-closed eyes, her tightly fitting bodice emphasizing exposed breasts, framed by delicate floral bouquets, and the child's transparent shift, which barely hides her nudity. ${ }^{11}$

\section{The inception of modernity in Iran}

To examine how Occidentalist fantasies framed the construction of "the modern" in nineteenth-century Iran, I have focused my investigation on Iranian travel writers in the half-century time period between 1813 and 1863 . The opening date, 1813, corresponds with Iran's defeat in a great war with Czarist Russia, which many scholars consider to be a turning point in the country's history. Similar to the shock that the Ottoman Empire experienced when it lost a war against Russia in 1774, this traumatic experience 
instituted a period of re-awakening, self-questioning, soul-searching, and openness in Iran's social history. ${ }^{12}$ The war, to use Foucauldian terminology, operated as a moment of rupture, break, and discontinuity in Iran's history, as it initiated the mentality of introspection, through a simultaneous curiosity towards other, more advanced, cultures. The self-criticism that followed this defeat brought about a strong desire to break with the traditions that seemed to be holding Iran back from the rest of the world. The existence of such shared experience of "perpetual disintegration and renewal" in Iran, as Marshall Berman would phrase it, ${ }^{13}$ especially prior to the country's direct engagement with Europe is a factor that should not be overlooked in discussions of modernist cultural exchanges.

Iranians had long interacted with their Western Others, whom they referred to as Farangis. During the several centuries since the concept was introduced in Persian literature, Farangestan (the West) was perceived as the land to an inferior and less civilized culture. Iranians' early awareness of modern Farangestan was gained during the nineteenth century. This awareness was mostly filtered through interactions with visiting foreign advisors, who were commissioned to provide military and technical training to local allies, or else through the tales of Iranian travelers who visited Europe. Foreign advisors offered a precise but narrow perspective on modernity as it related to their official duties and fields of expertise. Iranian travelers, in contrast, had the opportunity to see the modern European world as a whole. Many travelers, following a long-standing tradition of travel writing in Iran, kept notes on their journeys. These accounts are known in Persian literature as safarnamehs; they are arguably the first modern form of literary writing and the predecessor of the novel in Iran. For this study, safarnamehs serve as sort of an MRI, though which I can scan the authors' minds.

The experiences, emotions, and feelings of the traveler, as portrayed in safarnamehs, even when they are not recorded on the spot, are often noted within a day or two, which in result creates a collage of snapshot information, better reflecting subjective and fragmented observations. Unlike other genres of writing, safarnamehs did not seek to corral the narrator's experiences into a cohesive plot. Instead, they aimed for evocative imagery and impression. A common technique in these accounts was to use expressions of time as a measurement of distance, which makes the memoirs function as a kind of time-travel narrative. ${ }^{14}$ The travelers' intense desire to imagine Iran's future as prosperous, with the amenities that modernity has offered Europe, creates a hybrid narrative that constantly jumps between the reality of contemporary Europe and the imagined future of Iran. Yet, these memoirs, unlike the fictive character of futurist novels, map a present and already-existing destination, which makes them a reliable guide towards progress.

Although intended to be published, most nineteenth-century safarnamehs did not reach a broad audience in their time. They were primarily distributed 
and read by members of the nobility, who of course had significant political and cultural influence. The tradition of safarnameh in Iran had been a male discourse for centuries, and the time period of this study was no exception. The elitist and male-dominated demographics of safarnameh writing were in part due to the logistical difficulty and high costs of travel to Europe. With a few exceptions, the individuals who had the wealth, power, and freedom to make the journey were young male elites. They were often connected with the ruling class in Iran. For example, prominent authors in the genre included Mirza Hajibaba, who later became the doctor of the royal court; Khosrow Mirza and Rezaqoli Mirza, who were princes; Mirza Saleh, who became the official court translator; Ajudanbashi and Farrokh-Khan, who were ambassadors; Abolhasan, who was the foreign minister; and ultimately, Naseraddin Shah, who was the ruler of the country. This elitist background gave most of the safarnameh writers access to many European architectural and urban spaces that would have been closed to non-elites. At the same time, it should be pointed out, many of the spaces that accommodated the lower classes and mundane functions of European commoners were effectively hidden from their view.

Some might argue that the information communicated through travelogues is unrepresentative, subjective, inaccurate, and at times even intentionally deceitful, and that it is therefore an inappropriate source for research into historical realities. But because this study is not concerned with "objective reality" (if such a thing is even accessible), these characteristics of travelogues are actually the very traits that make them desirable for research purposes. ${ }^{15}$ They allows us to analyze the constructed reality of modernity that circulated during this era, and that later informed the perspective of the Iranian elites who had the capacity to invest in architectural projects.

Nonetheless, there are limitations that complicate the usefulness of travelogues in researching cultural history, and these drawbacks should be kept in mind when reading the following analysis. The writers of safarnamehs adopted a selective approach to their reporting based on the image they tried to portray of not only the objects and spaces they visited, but also of themselves. Their descriptions were often intended to fashion a self-portrait that differed from the actual socioeconomic, cultural, religious, and educational realities that the writers inhabited. Many of these writers also had a tendency to plagiarize from earlier sources, verbatim, and to report these earlier accounts as their own experiences. The writers' claims of having composed accounts of their impressions "on the spot" must always be treated as questionable, as we know that in at least some cases the writers did not even visit the locations they described. Despite these limitations, the impressions recorded in safarnamehs provide a unique window into the cultural imagination and idealized narratives of modernity that circulated among nineteenthcentury Iranian elites. 


\section{The first brick}

\section{The research odyssey}

In crafting this book, I see myself as a traveler in the unknown world of old manuscripts, and I wonder if I can manage to present the findings of this scholarly trip without merely projecting my expectations and prejudices onto the materials that I study. I am aware that no understanding is possible without preconception; this awareness, however, nudges me to apply even more rigorous methods to solidify my interpretation of the texts.

To see how the experience of European modernity was transformed by Iranian travelers' intentions, prejudices, ideals, and linguistic limitations, I study how certain spaces were depicted in each safarnameh. I ask, what are the differences between the space and its description? What causes this difference? Is a pattern identifiable? I also examine the differences between the travelers' descriptions of their encounters in Europe and their, often European, companions' explanations of the same spaces. I look closely at the literary styles, figures of speech, narrative devices, settings, themes, motifs, and tones of the safarnamehs to identify the imagery that various architectural features may produce. In this process, architecture and urbanism determine the criteria for the information taken into consideration for my study.

The travelers' perception of modern space involved a preconceived image about Europe, which I suggest was charged with utopian expectations. To use a more accurate terminology, I suggest that nineteenth-century Europe operated as a heterotopic destination to the travelers. Unlike utopia, which as its definition suggests, is nonexistent, heterotopias are real sites. The simultaneous reality and idealism of heterotopias allow for more tangible aspirations. The temporal distance that many of the travelers felt toward their contemporary Europe, was rooted in what Foucault would call a desire for an "absolute break with their traditional time."16

By proposing Europe as heterotopic destination for the travelers, I do not intend to reduce their ambivalent feelings into an uncritical glorification of the European lifestyle. However, the recognition of this utopian quest, the strength to cut away oneself from one's home, the will to explore faraway lands, and the desire to set foot on the heavens on earth, opens the door to understanding the cultural aspirations for such a difficult journey. This utopian imagery that was often rooted in Persian and Islamic ideals and norms filtered how the travelers evaluated the European Other, their own culture, and the association between the two. In other words, I argue that tajaddod, the name commonly given to Iran's experience of modernity, is a phenomenon that responded as much or more to the culture that conceived it as to the external influence of European developments. Emerging out of an intention to actively understand, control, manipulate, and emulate what modernity has to offer, tajaddod transcends a passive reflection of European values. 
The systematic constellation of ideas that grew to shape tajaddod confirms its discursive nature. While the discourse of tajaddod has fed through the intellectual investments of many generations, it remains as a form of pseudo-incarnation of the previously discussed expectation of modernity. The Iranian perception of modernity that tajaddod champions has been primarily concerned with the internal consistency of its heterotopic preconceptions, rather than its correspondence with modernity in the West. Similarly, the oppositional counter-discourses that have emerged to reject tajaddod in Iran are more about negating certain trends and ideals within Iranian history than modernity in the West. The intellectual infrastructure for ideas of mashru'a ${ }^{17}$ nationalism, gharbzadegi, ${ }^{18}$ and even the Islamic Republic, leaned heavily on a discursive opposition towards tajaddod. The architectural manifestation of such counter-discourses can be traced in styles and theories that romanticize an imagined pure past by glorifying local, Islamic, and/or Persian traditions of architecture.

Understanding how tajaddod is discursively rooted in Iran's culture is directly relevant to contemporary issues that Iranian architects face today. Theories, either pro or con, that perceive Iran's experience of modernity as nothing other than an attempt to emulate an essentially Western phenomenon alienate today's architects and planners (and others) from the modern heritage that blossomed in Iranian culture for almost two centuries. This book emphasizes the endemic Iranian desire for a modern utopia and recalls the influence of Persian ideals in the development of early Iranian modernism. Situating the origins of early modernist architecture of Iran in-between Persian utopia and an imagined Other problematizes categorical binaries that insist on a separation between the indigenous and the foreign, as well as between modern and traditional architecture in Iran. Formulating tajad$d o d$ as a multi-vocal, nuanced discourse with roots in Iranian history also provides a different perspective on contemporary debates about Islamization, nationalism, and traditionalism, by articulating these phenomena as counter-discourses, not to the West per se, but to an endemic Iranian perception and aspiration toward modernity.

\section{A cross section through the book}

I consider this work as a scholarly building. I hope my reader will enjoy the views that I provide and benefit from their time of residency in the text. This section serves as a kind of map to facilitate the readers' circulation in the book.

In the first chapter I have offered an initial tour and established the stability of the conceptual foundations for this building. The structures introduced here will underlie and support the weight of the expansive discussion and data analysis that I conduct in the following chapters. A basic understanding of these concepts, such as Otherness, Orientalism, Occidentalism, safarnamehs, and tajaddod, will be crucial for making sense of what 
follows. The brief presentation that I provided of my goals for this book and its implications will help in understanding the purpose behind the work.

Chapter two introduces my materials and sources: the travel accounts that I will be examining, and what we know of the authors. I have organized this chapter around the individual travelers to emphasize their personal backgrounds, their objectives, and the way that their unique perspectives affect their writing. The cases that I examine are travel accounts written by Mirza Abolhasan Khan Shirazi Ilchi, Mirza Mohammad Saleh Shirazi, Rezaqoli Mirza, and Aminoddowleh Abu-Taleb Farrokh-Khan Ghaffari. In addition to describing the biographies and travel details of these individuals, I provide information about their different literary styles, formats, and significance. By analyzing the various ways in which the authors narrate their voyages, I emphasize the differences between each travel account.

In chapter three I discuss how the concept of Farangi (Western) space was negotiated during the travelers' journeys to Europe. I show how the lack of an established vocabulary to describe this space contributed to the production of a domestic imagery of Europe, and I discuss how the travelers' measurements of space solidified the distorted imagery with quantitative authority. I also discuss how this image of Farangestan gained a kind of magical and delusional quality when the travelers were confronted with new artistic mediums, such as panoramas, dioramas, photography, and early cinematic devices, in which reality could not be distinguished from illusion. My main intention in chapter three is to show how the image of Farangestan sustained its Otherness and enriched its wonderfulness in the imagery of the travel memoirs.

In chapter four, I focus more specifically on the travelers' description of architecture and urban spaces. The chapter is organized around different spatial elements, including houses, roads, gardens, form, function, cleanness, stability, materiality, grandeur, hierarchy, order, ornament, and construction details. As is evident from this list, the elements discussed are neither comprehensive nor categorized based on any systematic or hierarchical order. These categories are rather extracted from repeated terms of emphasis that emerged in the travelers' writing, leading to a discussion of how space was perceived by the travelers and whether or not a pattern can be identified from their representations.

Chapter five serves as concluding turret for this edifice. Here, I summarize alternative perspectives to previous analyzes of Iranian modernism and offer new vistas for the reader to enjoy. My formulation of tajaddod (Iranian experience of modernity) as an ongoing discourse, which I have already briefly introduced in chapter one, is developed and presented as a window that frames the problematic issue of modernity in Iran.

\section{Notes}

1 Darius Shayegan, Cultural Schizophrenia.

2 Evan Thomas, "The Day That Changed America." 
3 "The central concern in Iranian intellectual and cultural discourses in the past 150," as Mirsepassi suggests, "has been the problem of reconciling modernity with Iranian culture" (Ali Mirsepassi, Negotiating Modernity in Iran, 64). For a detailed list of Iranian intellectuals who have attempted to theorize Iran's relationship with modernity, see Mehrzad Boroujerdi, “'The West' in the Eyes of the Iranian Intellectuals of the Interwar Years (1919-1939)," 394, 395.

4 Homa Katouzian, "The Short-Term Society," 18.

5 Hisham Sharabi, Neopatriarchy, 24.

6 Shayegan, Cultural Schizophrenia. Jalal Al-e Ahmad, Plagued by the West. For more information, see Mohamad Tavakoli-Targhi, Refashioning Iran.

7 Talinn Grigor, “Orient Oder Rome?” 573 (emphasis added).

8 Edward Said, Orientalism.

9 For example, revisit Death of Sardanapalus (La Mort de Sardanapale) painted by Eugène Delacroix in 1827. Once its objectification of the "Orient" is consciously put aside, one can recognize and appreciate the exotic fantasies of its author.

10 Although Said briefly discusses Occidentalism, the notion was first explored by al-Azm, who argues that essentializing tendencies towards the Other is grounded in an "imaginative exteriorization," and therefore, it is a universal desire (Sadik Jalal al-Azm, "Orientalism and Orientalism in Reverse"). The actual application of the concept of Occidentalism was perhaps first studied by Hanafi (Hasan Hanafi, Muqaddimah Fi Ilm Al-Istighrab). Looking at Chinese representations of the West, Chen expanded the literature by identifying two forms of Occidentalism: the official discourse by the state authorities that renders a negative vision of the West, and the anti-official discourse by the opposition that glorifies Western culture (Xiaomei Chen, Occidentalism; "Occidentalism as Counterdiscourse"). Other examples of literature on Occidentalism include: James G. Carrier, Occidentalism; Mehrzad Boroujerdi, Iranian Intellectuals and the West; Tavakoli-Targhi, Refashioning Iran; Ian Buruma and Avishai Margalit, Occidentalism; Rasheed el-Enany, Arab Representations of the Occident; Robbert Woltering, Occidentalisms in the Arab World; Occidentalisms; M. R. Ghanoonparvar, In a Persian Mirror; Laetitia Nanquette, Orientalism versus Occidentalism.

11 For a further discussion of the aesthetic tropes of the painting, see Layla Diba and Maryam Ekhtiar, Royal Persian Paintings, 208.

12 Bernard Lewis, The Muslim Discovery of Europe.

13 Marshall Berman, All That Is Solid, 30.

14 Nigel Leask, Curiosity and the Aesthetics of Travel Writing.

15 Evidence from safarnamehs has been frequently used in studies of Iranian cultural history. Examples of previous scholarship that relies heavily on this form of documentation include Javad Tabatabai, Ta'ammoli Dar Bareh-Ye Iran, 2; Ta'ammoli Dar Bareh-Ye Iran; Abbas Milani, Lost Wisdom; Tavakoli-Targhi, Refashioning Iran; Ghanoonparvar, In a Persian Mirror; Naghmeh Sohrabi, Taken for Wonder; Nile Green, The Love of Strangers.

16 Michel Foucault, "Of Other Spaces."

17 Mashru'a was a quasi-constitutional system in which a council of Islamic jurists, as the sole legal authority, would check the adherence of public law to sharia. For more information on mashru'a, see Abbas Amanat, "Constitutional Revolution."

18 Coined by Ahmad Fardid but publicized through Al-e Ahmad, the term gharbzadegi (literally, "plagued by the West" or "West-toxification") refers to the loss of cultural identity through a blind imitation of Western values. For more information, see Al-e Ahmad, Plagued by the West. 


\section{The first brick}

\section{References}

al-Azm, Sadik Jalal. "Orientalism and Orientalism in Reverse." Khamsin no. 8 (1981): 5-26.

Al-e Ahmad, Jalal. Plagued by the West [Gharbzadegi]. Modern Persian Literature Series. Delmor, NY: Center for Iranian Studies, Columbia University, 1982.

Amanat, Abbas. "Constitutional Revolution: Intellectual Background.” In Iranica, edited by Ehsan Yarshater, 163-176. New York: Bibliotheca Persica Press, 1992.

Berman, Marshall. All That Is Solid Melts into Air: The Experience of Modernity. New York, NY: Viking Penguin, 1988.

Boroujerdi, Mehrzad. Iranian Intellectuals and the West: The Tormented Triumph of Nativism. Mohammed El-Hindi Series on Arab Culture and Islamic Civilization. 1st ed. Syracuse, NY: Syracuse University Press, 1996.

—. " "The West' in the Eyes of the Iranian Intellectuals of the Interwar Years (1919-1939)." Comparative Studies of South Asia, Africa and the Middle East 26, no. 3 (2006): 391-401.

Buruma, Ian, and Avishai Margalit. Occidentalism: The West in the Eyes of Its Enemies. New York: Penguin Press, 2004.

Carrier, James G. Occidentalism: Images of the West. Oxford: Oxford University Press, 1995.

Chen, Xiaomei. "Occidentalism as Counterdiscourse: 'He Shang' in Post-Mao China." Critical Inquiry 18, no. 4 (Sum 1992): 686-712.

- Occidentalism: A Theory of Counter-Discourse in Post-Mao China. New York: Oxford University Press, 1995.

Diba, Layla, and Maryam Ekhtiar, eds. Royal Persian Paintings: The Qajar Epoch, 1785-1925. London: I.B. Tauris, 1998.

el-Enany, Rasheed. Arab Representations of the Occident: East-West Encounters in Arabic Fiction. Culture and Civilization in the Middle East. London, NY: Routledge, 2006.

Foucault, Michel. "Of Other Spaces.” Diacritics-a Review of Contemporary Criticism 16, no. 1 (Spr 1986): 22-27.

Ghanoonparvar, M. R. In a Persian Mirror: Images of the West and Westerners in Iranian Fiction. 1st ed. Austin: University of Texas Press, 1993.

Green, Nile. The Love of Strangers: What Six Muslim Students Learned in Jane Austen's London. Princeton, NJ: Princeton University Press, 2015.

Grigor, Talinn. “Orient Oder Rome? Qajar 'Aryan' Architecture and Strzygowski's Art History.” Art Bulletin LXXXIX, no. 3 (2007): 28.

Hanafi, Hasan. Muqaddimah Fi Ilm Al-Istighrab. al-Tabah 1st ed. Bayrut: al-Muassasah al-Jamiyah lil-Dirasat wa-al-Nashr wa-al-Tawzi, 1992.

Katouzian, Homa. "The Short-Term Society: A Study in the Problems of Long-Term Political and Economic Development in Iran." Middle Eastern Studies 40, no. 1 (Jan 2004): 1-22.

Leask, Nigel. Curiosity and the Aesthetics of Travel Writing, 1770-1840: 'From an Antique Land'. Oxford, NY: Oxford University Press, 2002.

Lewis, Bernard. The Muslim Discovery of Europe. New York: W.W. Norton, 2001.

Milani, Abbas. Lost Wisdom: Rethinking Modernity in Iran. 1st ed. Washington, DC: Mage Publishers, 2004.

Mirsepassi, Ali. Intellectual Discourse and the Politics of Modernization: Negotiating Modernity in Iran. Cambridge Cultural Social Studies. Cambridge, New York: Cambridge University Press, 2000. 
Nanquette, Laetitia. Orientalism Versus Occidentalism: Literary and Cultural Imaging between France and Iran since the Islamic Revolution. International Library of Cultural Studies. 1 vols. London: I.B. Tauris, 2012.

Said, Edward. Orientalism. 1st Vintage Books ed. New York: Vintage Books, 1979. Sharabi, Hisham. Neopatriarchy: A Theory of Distorted Change in Arab Society. New York: Oxford University Press, 1988.

Shayegan, Darius. Cultural Schizophrenia: Islamic Societies Confronting the West. Modern Intellectual and Political History of the Middle East. 1st Syracuse University Press ed. Syracuse, NY: Syracuse University Press, 1997.

Sohrabi, Naghmeh. Taken for Wonder: Nineteenth-Century Travel Accounts from Iran to Europe. New York: Oxford University Press, 2012.

Tabatabai, Javad. Ta'ammoli Dar Bareh-Ye Iran: Maktab-e Tabriz [Tabriz School and the Foundations of Modernity] [in Persian.]. 1st ed. Tehran: Nashr-e Negah-e Mo'aser, 2006.

- Ta'ammoli Dar Bareh-Ye Iran: Nazariyyeh-Ye Hokumat-e Ghanun Dar Iran [Theory of Constitutional Governance in Iran] [in Persian.]. 2nd ed. Tehran: Intisharat-e Sotudeh, 2008.

Tavakoli-Targhi, Mohamad. Refashioning Iran: Orientalism, Occidentalism, and Historiography. St. Antony's Series. New York: Palgrave, 2001.

Thomas, Evan. “The Day That Changed America.” Newsweek, Dec 30 2001, 40-71. Woltering, Robbert. Occidentalisms in the Arab World: Ideology and Images of the West in the Egyptian Media. Library of Modern Middle East Studies. London: I.B.Tauris, 2011.

. Occidentalisms: Images of the West in Egypt. Leiden: Leiden University, 2009. 


\section{Modernity in a suitcase}

\section{Innocents abroad}

There are very few firsthand Iranian travel accounts from the early nineteenth century that still exist today. Travel writing at that time was not an easy task. The handwritten manuscripts were threatened by the hazards of long journeys, and their authors were limited by the inconveniences of the road. Rezaqoli Mirza recalls an incident in Istanbul when members of Ottoman nobility asked to see his writing:

To avoid the dangers of plague, I asked one of my new servants . . to heat the manuscripts with smoke ... while I was talking [to my guests], I realized that the stupid fellow was burning sections of the only copies of the books that I have been writing with such hardship and for such a long time! ... Since it was already over, there was no sense to punish the foolish servant. I rewrote whatever I could recollect, a small portion [of what I had lost]. ${ }^{1}$

Rezaqoli's companion, Assaad Kayat, who translated the book into English, also lost portions of the manuscript during his trip:

The translator of these pages exceedingly regrets that the latter part of the history, consisting of about twenty pages ... was robbed on his journey. ... He considers himself very fortunate that the Bedouins only took these few sheets from the book for curiosity; for when they examined his saddle-bags on the camel, and found that it contained books and letters, and other papers, they asked him why he was so great a fool as to carry, along with him such a load of useless papers and books, which could neither be eaten nor drunk. ${ }^{2}$

Travelers who intended to record their journeys were thus confronted by many difficulties, which did not always cease upon their return to their homeland. Regrettably, some of these accounts were never published and continue to exist today only as privately owned unique manuscripts. 
The travelers whose writings I examine in this book are Abolhasan Ilchi, Mirza Saleh Shirazi, Rezaqoli Mirza, and Farrokh-Khan Aminoddowleh. During the first half of the nineteenth century, only a handful of other travelers to Europe also wrote their memoirs, most significantly Khosrow Mirza and Ajudanbashi. ${ }^{3}$ Khosrow Mirza visited Russia and, while he also traveled through the European portions of the country, his diary does not qualify as a report on Farangestan (Iran's Western Other), as Russia was a familiar neighbor to Iran. I had initially studied three diaries of Mirza Saleh, Rezaqoli, and Farrokh-Khan, who set out to Europe respectively in 1815, 1836, and 1855, each twenty years later than the other. Later I decided to include Abolhasan's memoir, especially because multiple parallel reports about his stay in England allowed me to validate his descriptions. Given their authors' diverse backgrounds, the four diaries that I study here appropriately represent a larger body of existing travelogues during this critical period. The travelers each come from different backgrounds in terms of their social class, wealth, and occupation - not to mention their objectives and the duration of their journeys, and the places and people they visited. The travelers had different levels of education and different degrees of literary skill, and they each shaped their observations in accordance with the particular images that they wanted to convey to their intended audiences. For example, Mirza Saleh, who came from a relatively modest economic background, devoted much of his writings to the impoverished classes in England and their social service structures, such as orphanages, charity schools, workhouses, madhouses, children's hospitals, and other medical treatment centers. ${ }^{4}$ Farrokh-Khan and Rezaqoli, in contrast, were members of the Iranian aristocracy and showed a greater interest in military facilities. ${ }^{5}$ While institutions of commerce and industrial manufacture had a great impression on Farrokh-Khan, Mirza Saleh was fascinated with institutions related to education and democratic governance. Abolhasan, on the other extreme, showed a dismissive attitude towards democracy but was keen to learn about the royal protocols of the British court.

In this chapter I introduce the four travel memoirs and explain their significance. I also describe what is known about each author and discuss the particular goals, personal backgrounds, and literary traits that the authors bring to their narrations.

\section{Abolhasan}

Mirza Abolhasan Khan Shirazi Ilchi (1776-1846) was the nephew and sonin-law of Haji Ebrahim Khan E'temadodowleh, who served as the prime minister of Iran during the early years of the Qajar dynasty (see Plate 4). With such prominent relatives, Abolhasan soon entered into the political circle of the Qajars, becoming for a short time the governor of Shushtar. In 1800, however, his patron Haji Ebrahim fell out of favor and was imprisoned, so Abolhasan fled to Basra and from there set off for India, where he 
remained for several years. In 1808, he received a royal pardon and returned to Iran. Through his connections, Abolhasan was able to put these events behind him, and he continued to rise in political distinction in the Shah's court. In 1809 he was sent to England on a diplomatic mission, which earned him the title of Ilchi (literally, "envoy").

Returning to Iran after his initial travels in Europe, Abolhasan received the honorary title of Khan and became a significant player in Iran's foreign affairs. He was responsible, among other things, for drafting and signing the treaties of Golestan and Torkamanchai, which put an end to Perso-Russian war at the expense of Iran's northwestern provinces. Abolhasan embarked to the court of St. Petersburg as a special envoy in 1815, and was dispatched again to England in 1819. In 1823, he became Iran's second minister of foreign affairs, a position he held until Fath Ali Shah's death in 1834. He was appointed as the foreign minister for a second time in Mohammad Shah's court, from 1838 until his death in $1846 .^{6}$

The travel journal of Abolhasan that is discussed here was written during his first diplomatic trip to England, from 1809 through 1811. Copies of the diary have since remained in multiple archives. For this study, I have relied on both a Persian publication and an English translation of a manuscript that apparently belonged to one of Abolhasan's descendants. ${ }^{7}$ The two versions complement one another as the Persian copy has been heavily censored by its editor and the English translation only covers the European sections of Abolhasan's journey. To see the route that Abolhasan took during his journey, refer to Plate 2; a detailed itinerary of the places that he visited on this trip can be found in Appendix A.

\section{Inquisitiveness}

In the opening pages of his journal, Abolhasan emphasizes that he has "recorded the events that [he has] witnessed in a daily fashion." ${ }^{8}$ However, instances of confusion about the dates and the order of events in the text strongly suggest that Abolhasan later inserted new material and expanded on whatever notes he recorded on a daily basis. ${ }^{9}$ The original version of the manuscript contains numerous blank spaces, mostly related to specific information about people and places. ${ }^{10}$ Presumably, much of the other information presented in the journal may have been later inserted by the author as he attempted to fill in the blanks. The level of detail with which these informational texts were written suggests their author's strong curiosity and engagement with recording the world around him. As James Morier, who traveled with Abolhasan in this trip, reports, "He did not miss a single opportunity on informing himself on everything which he saw on board; and whatever he learned, he carefully noted in the book." 11

Abolhasan's narrative emphasizes the formal affairs of European nations, including brief forays into history and geography, diplomatic conducts, the political structure of Britain, the responsibilities of each minister, and details 
of voting, parliaments, parties, annual incomes, and expenses of state. ${ }^{12}$ Most of this information seems to be a result of Abolhasan's inquisitiveness as an international envoy. His regular contact with state administrators and literate hosts allowed Abolhasan to collect firsthand information on the topics of his interest. Abolhasan usually trusts his sources and only occasionally shows suspicion towards their information. ${ }^{13}$ His sources are almost exclusively oral, with the exception of a single instance in which he cites "the annual state reports." ${ }^{14}$ Apparently, Abolhasan's detailed financial information on state incomes and spending are cited from these reports. Abolhasan requested access to history books from the library of the East India Company, but the extent to which he may have incorporated information from those texts into his descriptions is unknown. ${ }^{15}$

The factual information that Abolhasan reports is intermixed with personal narratives, apparently without organizational concern. In reviewing the manuscript as a whole, however, an underlying pattern is recognizable. As the writing develops, Abolhasan gradually begins to include a greater number of informative segments, while the poetic and personal character of the journal shifts slightly toward the background.

\section{Self-esteem}

Abolhasan appears to have possessed a distinctly emotional and sensitive character. He became homesick very early in his trip, and constantly sought means to expedite his return to Iran. ${ }^{16}$ His attendant, Sir Gore Ouseley, notes an instance in which news of a delay in his mission brought Abolhasan to tears, which apparently was not the only instance of such affective display. ${ }^{17}$ In his writing, Abolhasan also expresses grief quite frequently, for example when watching an opera, at a Thanksgiving service for orphan children held in St. Paul's Cathedral (see Plate 3), and when departing from his British friends. ${ }^{18}$ As a sensitive person, Abolhasan also seems to have been quick to feel offended, especially when detecting ill-treatment from others. He "grew very anxious," as his companion Morier writes, when he was not well-received upon his arrival to London. Morier also characterizes Abolhasan as jealous of the honors paid to other diplomats. ${ }^{19}$ Abolhasan seems to confirm this assessment when he writes to complain, for example, of an occasion in which the Mayor of London's wife was "discourteous" to him, or when he describes the Duchess of St. Albans as, "a stupid woman, ignorant of protocol, she paid me no attention at all." 20

Abolhasan's unstable self-esteem is shown not only in his concern for his diplomatic ranking and social status, but also in his self-image as an intelligent and cultured person. Having travelled to Mecca, Medina, Basra, Kolkata, Murshidabad, Hyderabad, Pune, and Mumbai prior to visiting Europe, and with a knowledge of the Persian, Hindi, Turkish, English, and Russian languages, it is perhaps unsurprising that Abolhasan regarded himself as an accomplished person who has traveled the world. ${ }^{21}$ This rendering 
of his identity as a learned and well-traveled individual appears frequently in his writing, often to the extent that the voices of those he meets are put into the service of his self-appreciation. He is, after all, a "young, noble, and learned" fellow, as both the British foreign minister and the British King address Abolhasan in his own writing. Quite frequently, Abolhasan reminds his readers that the English nobility are astonished by his "eloquence," his "mastery of language," his "intelligence," as well as his quick grasp of English. ${ }^{22}$

This refined self-perception greatly affects the style of Abolhasan's narrative. On the very first pages of his journal he asks his readers to "forgive the humble author for avoiding a rhythmic language and colorful metaphors, adorned with rich rhetoric; because the aim of this text is to report the events." ${ }^{23}$ Despite this disclaimer, his prose is expressive and flowery, and it is frequently adorned with verses of Persian poetry, both quoted and original. Abolhasan's description of Hyde Park is only one example among many others:

Indeed, it is a vast and delightful pleasure-ground - as exhilarating as a draught of wine. If a sorrowing soul traverse these heavenly fields, his head is crowned with flowers of joy, and looking on these saffron beds luxurious as Kashmir's - he smiles despite himself. In the gardens and on the paths, beauteous women shine like the sun and rouse the envy of the stars; and the houris of paradise blush with shame to look upon the rose-cheeked beauties of the earth below. In absolute amazement, I said to Sir Gore Ouseley: If there be paradise on earth, it is this, oh! It is this! ${ }^{24}$

Beyond its effect on the form and content of his narrative, the literate selfimage that Abolhasan tried to promote was related to the very act of his writing. The creation of his journal was a kind of performance art that helped him to consolidate his image in the minds of his companions. In comparison with the other travelers discussed here, Abolhasan's writing activities were much more visible and public. Not only did his close companions, such as Morier and Ouseley, have much to say about his constant scribbling, but even such luminaries as King George III advised him to "take note of our conversation in your diary." 25 The act of travel writing for Abolhasan becomes a tool to render/sustain his desire to be associated with literary refinement - similar to the role played by the small notebook (possibly his diary or the Quran) that he holds in both of his portraits painted by Sir William Beechey and another by Thomas Lawrence (see Plate 4). ${ }^{26}$

\section{Humor}

The image of intelligence and refinement that Abolhasan desired to portray partially explains the many humorous segments in his journal. It should not 
come as a surprise that he often describes scenes in which his wit and perspicacity (or as he would put it, his sokhan-e shirin, latif, abdar) win the praise of distinguished companions. ${ }^{27}$ Abolhasan has recorded many examples of such "quick, intelligent, and humorous responses" in his travelogue. When asked whether he is a fire-worshipper, he responds, "in London I should be a sun-worshipper if the sun were not as invisible as the fabulous Phoenix." When asked by the Prince of Wales about his homesickness, he responds that his sorrows are "swept away by ... being received by his Royal Highness." When asked to give the name of the doctor who cured him, he responded, "I [know] of no better doctor than chastity." When asked by a young lady whether he has visited any churches, he responds "not yet, as I am waiting for your hand [in marriage]." 28 This cavalier attitude is confirmed by William Waldegrave, in an article he wrote for Gentleman's Magazine in 1820:

[Abolhasan] laughed heartily at the folly of bringing forward Peter the Great and his Empress as dancing to divert the throng. . . . Soon after, he jokingly said, "When I get back to my own country, the King shall ask me, 'What did the English do to divert you?' I will answer, 'Sir, they brought before me your Majesty's enemies, the Emperor and Empress of Russia, and made them dance for my amusement.' "29

There does seem to be a very authentic aspect to Abolhasan's humor. Friends celebrated his amiable disposition, ${ }^{30}$ but even those who thought poorly of him grudgingly admitted to the effects of his charm. One detractor wrote, "it is true, he is plausible; his constantly-sustained laugh gives him an appearance of good-humour." 31

Abolhasan would often joke with his peers, as he once pretended to a priest that he was considering conversion, which greatly excited the trusting priest. ${ }^{32}$ According to one story, he maintained this attitude even with those whom he barely knew:

As he [Abolhasan] was seated on a bench [at Kensington Gardens], an old gentleman and an old lady, taking him for one of his own attendants, accosted him. They asked him many questions - "How does your master like this," and "how does he like that," and so on. Tired with being questioned he said, "He like all very well; but one thing he did not like - old man ask too many questions." Upon this, he got up laughing, leaving the old couple to find out that they had been speaking to the Ambassador in person. ${ }^{33}$

Abolhasan's humorous attitude towards others would in return encourage them to participate in the same antics at his expense. Ouseley once disguised himself in a Persian garment at a masquerade ball and tried to trick Abolhasan into believing he was another traveler from his homeland. One lady jokingly accused him of sending her love letters, and even King George III 
made a "royal joke" about the form of Abolhasan's dancing. ${ }^{34}$ Abolhasan truly enjoyed the companionship of "sweet-spoken" people and admired "good humor." ${ }^{35}$ In his journal, Abolhasan frequently reported not only his own jokes, but also those he had heard from others, such as a story of a lady who used fake pubic hair to please her husband, and a coach accident in which a man with a huge grumbling stomach passed gas as people fell on him. ${ }^{36}$

It is interesting to note that the humor of these moments, as recorded in Abolhasan's journal, is almost never at the expense of his situation as an odd character in a foreign land. The jokes are centered on shared human conditions, regardless of cultural differences. Abolhasan never indicates any amusement from the vastly different, and to him unusual, cultural practices that he was exposed to. In fact, the only time in his writing that he comments jokingly about English culture is once when he is asked directly by the King about the peculiarities that he has witnessed in England. ${ }^{37}$ For the most part, however, as a person who has travelled to many different countries, Abolhasan sees no inherent humor in cultural differences and avoids characterizing them as a source of amusement.

This approach to humor can be contrasted with Morier's famous satire, The Adventures of Hajji Baba, which drew from Morier's interactions with Abolhasan..$^{38}$ The satire of Hajji Baba, a bestseller in England and possibly "the most popular Oriental novel in the English language," 39 is radically different from Abolhasan's brand of humor. For Morier, the situation of an oriental society when contextualized within its nineteenthcentury "civilized" world was inherently paradoxical, and thus humorous. He adopts a condescending tone and a stereotypical narration to render his Persian subject as dishonest, violent, and idiotic, thereby reassuring Western audiences of their cultural and moral superiority. Ironically, while Morier himself had a "surprisingly weak knowledge of Persian," he cheerfully exploited Abolhasan's grammatical mistakes in English as a way to enrich his humor. ${ }^{40}$

As can be seen in these examples, Abolhasan's humor did not suffer from a reverse condescending mockery of the European Other. This was not simply because Abolhasan never had a similar opportunity to witness Europeans as an out-of-place minority in his own homeland. In fact, he had been in contact with Morier, among others, in Iran before his departure for Europe. It was also not because Abolhasan preferred English customs to his own in many cases he openly disapproved of the traditions and norms of his English friends. Nor was it because Abolhasan avoided offensive comedy; he frequently engaged in arrogant mockery toward others, for example by comparing the whimpers of a seasick servant to the sound of a donkey. ${ }^{41}$ If Abolhasan's humor is devoid of any tendency to ridicule European customs, it is simply because he did not recognize such cultural differences as a result of an essential and polar divide between the East and the West. Unlike social divisions, he viewed cultural divides as incidental, similar to the differences 
among the various ethnicities and religions in his own country, or among the various Arab and Indian societies that he had visited.

\section{Significance}

Abolhasan's writings never found the large public readership of Hajji Baba, which was soon translated into Persian and published in Iran. Instead, however, Abolhasan's memoir became an object of interest among the small but influential circle of nobility within the Shah's court, where multiple copies were immediately made to respond to its high demand. ${ }^{42}$ After his return to Iran, Abolhasan talked constantly with his peers about his observations of England (and, later, Russia). ${ }^{43} \mathrm{He}$ was said to have kept his audiences in constant wonderment with tales of his adventures, encouraging them to read more in his book. ${ }^{44}$ This primarily oral mode of circulating ideas related to the West was quite common among the Persian nobility, as is attested by Morier and others. ${ }^{45}$

Abolhasan's writings, and their influence in the Persian court, also received some degree of attention in Europe by the time of his second visit to England in 1818-1819. As usual, his status as an author took center-stage as a prominent aspect of his persona:

During his travels he has collected general ideas respecting the customs and manners of the nations he has visited, and the arts cultivated by them: he has written an extensive narrative of his travels in India, Turkey, Russia, and England, to which the King of Persia has given the pompous title of Hairet-nameh (the book of wonders). Mirza AboulHassan [Abolhasan] proposes to augment the work by his recent observations on Germany and France. ${ }^{46}$

Aside from keeping a record of his daily activities, Abolhasan saw his writing as an opportunity to communicate his diplomatic efforts to his superiors. But as his writing on the topic developed, Abolhasan felt that his diplomatic notes could be of great value to other ambassadors. ${ }^{47}$ While the books' effect on future diplomats is not clear, Abolhasan's memoir and those of his peers became, as he would put it, "an instruction manual" to the modernization of Iran in the later decades. ${ }^{48}$ Abolhasan may not have predicted such an influence but he certainly hoped for it; as Morier suggests: "All these things the mirza [Abolhasan] carefully noted down in his book, ever exclaiming, 'God grant that all such things may take place in my country too!' "49

\section{Mirza Saleh}

As part of an attempt to modernize their country, the crown prince of Qajar Iran, Abbas-Mirza (1789-1833), and the grand vizier, Mirza-Bozorg Qa'emmaqam (d. 1822), sent two groups of students to England to become 


\section{Modernity in a suitcase}

familiar with modern technology. The first group was sent in 1811 and the second in 1815. Among the second group was Mirza Mohammad Saleh Shirazi (circa 1790-1845), who studied history, natural philosophy, English, French, and Latin in England (see Figure 2.150). Upon his return to Iran, Mirza Saleh, according to the historian Nile Green, "[became] the closest advisor of the heir to Iran's throne." ${ }^{51} \mathrm{He}$ was appointed as the state's official translator and later became the vizier of Tehran. ${ }^{52}$

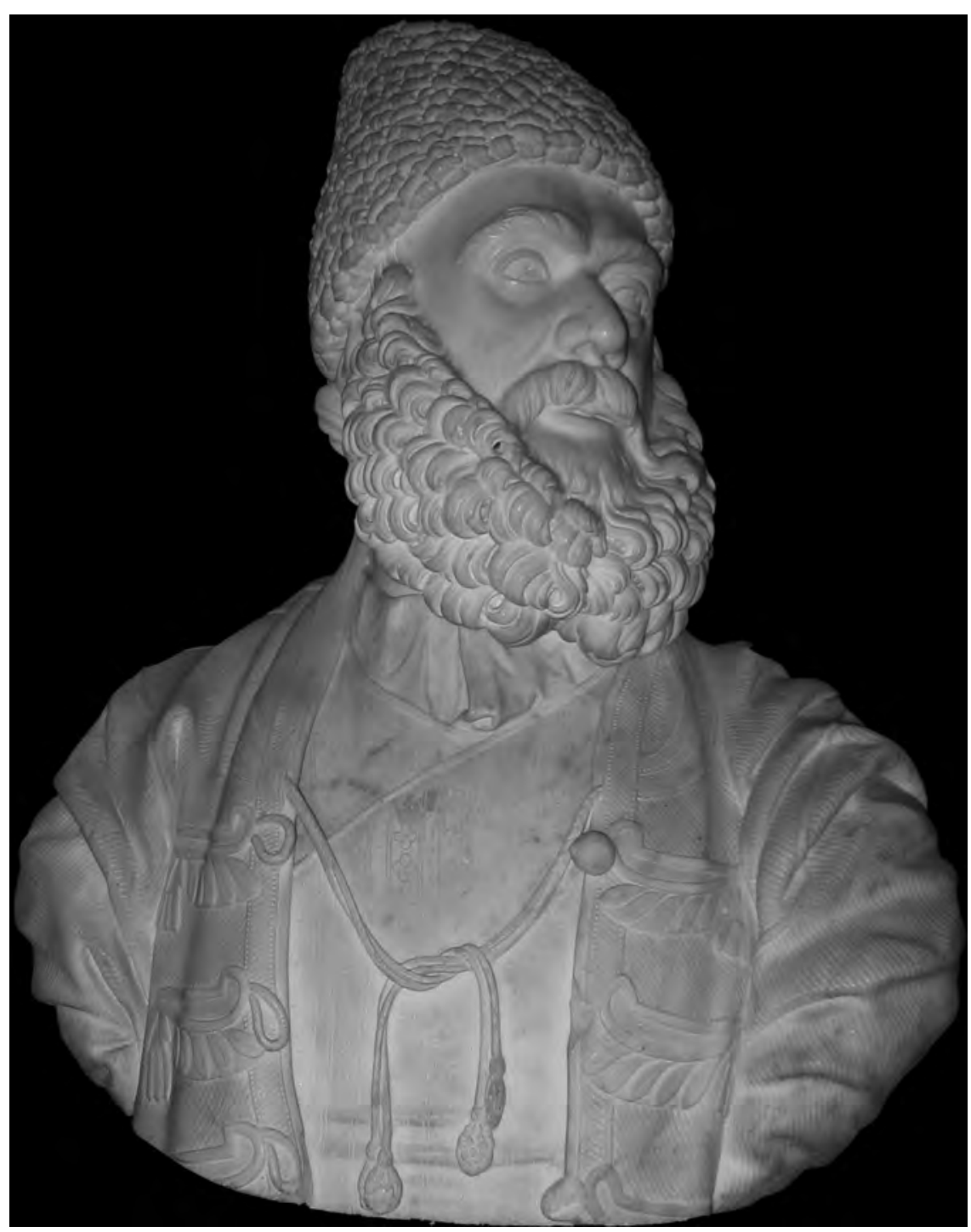

Figure 2.1 An 1823 sculpture of Mirza Saleh by Robert William Sievier.

Source: Cultural Institute of Bonyad Museums. 
Mirza Saleh was renowned for his scholarly knowledge. During their 1811 trip to Iran, Mirza Saleh assisted the British Orientalist William Price and the British ambassador Sir Gore Ouseley in their research on Iran. He also authored a set of dialogues in Persian that were translated to English by Price in his Grammar of Three Principle Oriental Languages. ${ }^{53}$ In Iran, Mirza Saleh is best known as the country's first newspaper publisher. He established one of the first printing presses in Tabriz in 1819, and by 1837 he had opened a press in Tehran, where he published a newspaper called Akbbar-e vaqaiyyeh (News of Events). ${ }^{54}$ To see the route that Mirza Saleh took during his journey, refer to Plate 5; a detailed itinerary of the places that he visited on this trip can be found in Appendix B.

\section{Narrative organization}

Mirza Saleh's writing has a very clear and distinct organizational structure in comparison with the other writers that I discuss. This author paid careful attention to the style, arrangement, and content of his narrative. His emphasis on these matters can be seen in his own descriptions, for example when he explains the organization of the text to his readers: "Wherever I arrive, I start by introducing the place and its history, and then I describe my ruzaneh [diary]." 55 Mirza Saleh also apparently sought out literary advice from his peers as to what points in his journeys should merit a notation. One instructed him to take up the pen "whenever some major incident occurs ... for example when the ship's mast breaks, when thunder strikes, or when water floods into the ship." ${ }^{56}$ But Mirza Saleh was just as interested in documenting the social and historical realities of the places he visited as he was in narrating his personal adventures. This penchant for rational organization and completeness in description separates him from the prevalent literary style of his time. His writing is very simple and unadorned in comparison with other travelogues. He is also the only writer among the ones discussed in this book who does not incorporate poetry into his narrative, as was the convention at the time.

The content of Mirza Saleh's travelogue is comprised of two very different types of materials, each of which is voiced through a different narrative device. ${ }^{57}$ The first kind of description is what he calls ruzaneh, or daily memoirs. This material centers around the author's personal experiences during his journey, and he uses the first-person narrative voice here to communicate his feelings, observations, encounters, discussions, and difficulties. Mirza Saleh explains, "During the day, I traverse the city and investigate the urban affairs and the people's traditions and behaviors as much as I can, then I record whatever is possible in this ruzaneh." 58 Aware of the genre expectations and precedents of Iranian travel writing, he lays out this ruzaneh in the typical safarnameh format, or in his own words, "the way travelers do it." 59

The second part of Mirza Saleh's writing consists of sections dedicated to educating the reader about issues that he finds important. ${ }^{60}$ In these passages he takes an expository narrative voice and provides detailed accounts of topics 


\section{Modernity in a suitcase}

such as Napoleon's biography and his army's invasion of Moscow, the history and geography of Russia, and the history, political structures, and economic institutions of England. Mirza Saleh frequently reiterates in these passages his desire to focus on broad socioeconomic issues. He emphasizes the development of the whole rather than stories of individual grandeur; or as he describes it, "the process of progress in this land, not the history of kings." ${ }^{61}$ Perhaps recognizing that these kinds of analytical passages diverge from the more expressive and personalized tropes that readers would expect from his genre of travel writing, Mirza Saleh is sometimes apologetic about their inclusion:

During the three or four months [that I am in London], it would be a good idea to write about England, its condition, its regions, and how they are structured, as I did in Russia. Writing about this region requires detailed articulation, otherwise it would be difficult to understand. . . . Therefore, I need to write in detail about the affairs of this era. I hope the readers will forgive me for the length of my writing. ${ }^{62}$

While these informative sections, whether the author's own expository analysis or his translations of Western sources, ${ }^{63}$ are recognizable from their third-person voice, they remain scattered throughout the memoir and integrated with daily diaries. However, their length, internal organization, and narrative style suggest that they were intended to be excerpted and published separately from the travelogue.

\section{Objectivity}

Mirza Saleh's attention to objectivity is a distinguishing characteristic of his writing, in relation to the other travelogues discussed in this study and in contradiction to the typical literary style of his time. He is a close observer who seeks precise information and authoritative sources for his reports. For example, in describing the wool industry in Exeter, Mirza Saleh explains, "I asked one of the accountants how much wool is traded in the city. He informed me that each week between 80 and 100 thousand tomans worth of wool is traded." ${ }^{64}$ Likewise, when writing about the economy in London, he cites details from the custom authorities' annual reports. ${ }^{65}$ Mirza Saleh usually takes an analytical bent in approaching these sources; in many instances he cross-examines the data from multiple provenances, expresses doubts, makes his reasoning process clear, and suggests alternative viewpoints. One such passage can serve as an example:

Regarding the population of Moscow, it is 500,000 as the Russians as well as some of the Iranians here report by word of mouth. But according to a French history book and two English [books] ... which were written with precision and research, the population that resides in the city is 250,000 and the population in the surrounding villages is $50,000 .{ }^{66}$ 
In this passage and others, Mirza Saleh exhibits a preference for exact figures and authoritative documentation:

If the regular people, or any other person, are asked about the number of public baths, they would reply that 200,000 or 300,000 baths, 15,000 mosques, and 2,000,000 houses exist in Istanbul. Nevertheless, the Efendi, which means the sheriff of Istanbul, has reported the number of houses to the authorities. I got a copy of this report from an English doctor. There are 88,185 houses in Istanbul. ${ }^{67}$

Mirza Saleh's work is also distinguished from the other sources in this study by his commitment to communicate the sources of his information, even when citing the words of other individuals. ${ }^{68}$ Like a cautious scientist, Mirza Saleh tries hard to avoid absolute phrases so that he can keep his report safe from falsehood. Many of his sentences open with qualifying terms such as "seemingly," "reportedly," and "probably." His penchant for precision in reporting leads him to express caution about sources that he cannot validate. ${ }^{69}$ Even when, as he writes, "the English Mr. William, as well as Mirza Abolhasan Khan, and most people in general, say that this city [St. Petersburg] is the best of Farangestan cities," Mirza Saleh refrains from delivering a conclusive verdict: "so far, I have not witnessed a better city myself."70 This distrustful attitude towards information that he cannot verify intensifies when the news is sensitive or important. Reacting to the most important news of his time, Mirza Saleh states, "I have heard that Napoleon has lost the war, but since it hasn't been confirmed yet, I shall not take it seriously." 71

Mirza Saleh goes so far as to leave many of his descriptions incomplete because he refuses to report on issues that he cannot verify. In a number of such cases he explains, "I did not have enough time to investigate the issue accurately," or "I did not see the remainder of the rooms on the third floor," or "I was not allowed to visit inside the building," and then he simply expresses his regret that he cannot write further on the subject. ${ }^{72}$ Additionally, while other travelers discussed in this study (some of whom were substantially less informed than Mirza Saleh), tend to conceal their weaknesses in communicating with others, Mirza Saleh does not seem to be ashamed to acknowledge that the several languages he commanded sometimes fell short of providing clarity. For example, in explaining the plot of a play that he saw in Moscow, Mirza Saleh leaves his narration incomplete by admitting "I did not understand the rest of their conversation." 73

Perhaps one of the most significant indicators of Mirza Saleh's commitment to an objective and contextualized reporting of his observations is his use of measurement systems. Whereas the other travelers discussed in this book generally adhere to Iranian measurements as much as possible, ${ }^{74}$ either because they are more accustomed to these measures or because they feel their readers would expect it, Mirza Saleh consistently adopts to the units of the country he is visiting. He also makes sure to fully explain these new systems to the reader. When leaving Tbilisi, for example, he reminds his 


\section{Modernity in a suitcase}

readers that "from now on, it is necessary to know that the Russian unit of length is called verst, and every seven versts is equal to one farsakh."75 This approach, I believe, indicates that Mirza Saleh is inclined to analyze the findings of his trip based not on a predetermined mindset but, as much as possible, from within the framework of the local social context.

\section{Didacticism}

As a scholar whose main purpose in visiting Europe is to pursue his education, Mirza Saleh treats his memoir as an opportunity to take notes, record information, and disseminate the knowledge that he gains through his travels. He has a clear agenda to educate his readers, a great majority of whom never get a similar chance to observe Europe firsthand:

Because I have stayed in London quite a while, I think it is best to write about London, its history, places, buildings, schools, and other characteristics, as well as its government and commerce, so the reader who has not seen the city can get informed. ${ }^{76}$

Mirza Saleh's desire to educate his readers appears to make him more conscious about the presence of an audience for his writing. He addresses his readers directly on a regular basis, a pattern that is unique among the other travelers examined here. Furthermore, he seems to be much less interested in impressing his audience with amusing stories about the peculiarities of Europe. For the most part Mirza Saleh adopts a detached, scientific tone that leaves little room for fictional embroidery. His writing seems totally devoid of any normative position; it is as if nothing can thwart his positivist mood, not even a castle in Isfahan that people believe to be the property of one of King Solomon's demons, ${ }^{77}$ or the acrobats and tightrope walkers in Vauxhall Gardens (see Figure 3.1).

While other travelers would not miss the opportunity to eroticize their Western experiences and excite their readers, Mirza Saleh's descriptions of swimming pools that are not gender-segregated, or artists in the Royal Academy of London who are painting a nude model, are limited to short objective descriptions. ${ }^{78}$

\section{Significance}

Mirza Saleh is the only writer among the ones discussed here who was able to publish a version of his travelogue for widespread circulation during his lifetime. Both the Persian manuscript and an English translation of excerpts from it were published in the $1820 \mathrm{~s} .{ }^{79}$ Aside from his diary, as the historian Nile Green suggests, "For over the course of more than a century and a half, the transfers of knowledge made by Mirza Salih [Saleh] and his companions would utterly transform Iran." ${ }^{80}$ Mirza Saleh's historical account, and his transgressively simple and clear literary style, were quite influential in Iran over the following decades. Even today, his memoir is often referred to as 
the "first history of England in Persian" and "the first step towards modern history" in Iran. ${ }^{81}$

Mirza Saleh's memoir is also significant in that he wrote, not only about the West, but also about his travels within Iran. By comparatively studying Mirza Saleh's writings about his trip to Europe alongside his descriptions of domestic travels, it is possible to gain greater insight regarding his perceptions of the West.

\section{Rezaqoli}

Upon his succession to the throne of Iran in 1834, the Qajar ruler Mohammad Shah (1808-1848) discharged and imprisoned his uncle and perceived rival, Hoseyn-Ali Farmanfarma. Fearing for their lives, Farmanfarma's family fled to Baghdad. The oldest son of this family, Rezaqoli Mirza, sought British support to free his father and claim back their land and properties. With this intention, Rezaqoli and his two brothers, Najafqoli Vali and Teymur Mirza (see Figure 2.2), set out for England in 1836. During this trip Rezaqoli took detailed notes, which were later translated into English by Asaad Kayat and published in $1839 .{ }^{82}$ The published copy of the book in Persian has missing sections, for example a large chapter on America, an important entry about joining the Masonic lodge, and sections related to his brother's romantic attachment to an English lady. Since the translator also lost sections of the book before it was published, I have used both the Persian book and Kayat's translation for this study.

Kayat, who accompanied the brothers during their trip, found this writer to be "remarkably quick of comprehension" and "a man of superior talent and wisdom." ${ }^{83}$ Rezaqoli knew Turkish and some Arabic, and he was quite informed in Persian literature and history. James Baillie Fraser, a Scottish travel writer and artist who accompanied the princes during part of their journey, likewise describes Rezaqoli as a man possessing "very amiable dispositions, gentlemanly feelings and manners; a great deal of innate dignity of character." ${ }^{84}$ Fraser was not reluctant to criticize the character of his various subjects and companions, but he consistently praises Rezaqoli, stating that he had never known "a Persian of any rank possessed of so many amiable qualities." 85

Rezaqoli's two brothers play an important ancillary role in his narrative. Teymur Mirza, the youngest brother, was known for his bravery and strength. ${ }^{86} \mathrm{He}$ was fond of drawing and enjoyed playing the santur, a Persian hammered dulcimer. Kayat describes him as a "celebrated warrior, horseman, and hunter," while Fraser commented on his vivacity, gallantry, and cheerful disposition. ${ }^{87}$ Vali, who was the stepbrother of Rezaqoli and Teymur, was the most learned among the three. Although less sociable, he was well-informed in literature, geography, religion, and the history of Iran. Kayat knew Vali as a renowned scholar and poet, and enjoyed discussing religious subjects with him. ${ }^{88}$ Fraser praised Vali as "shrewd and intelligent, well versed in the learning and accomplishments of his own country, a keen 


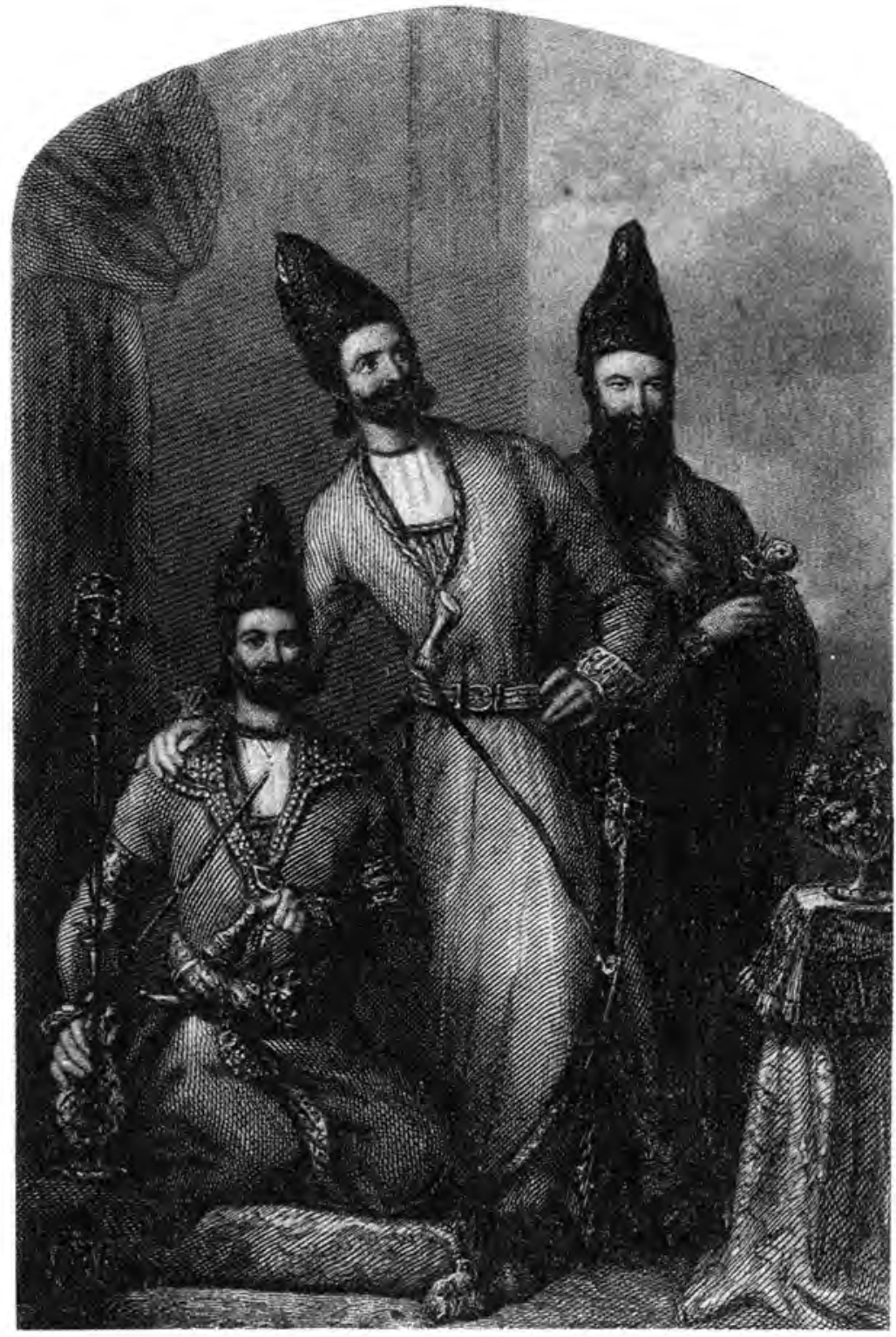

Figure 2.2 From left to right, Rezaqoli Mirza, Teymur Mirza, and Vali. Drawing by John Partridge, July 1836.

Source: James Fraser's Narrative of the Residence of the Persian Princes in London. 
observer, an acute reasoner, with a decidedly intriguing and diplomatic turn, and a general force of character." ${ }^{\prime 9}$ To see the route that Rezaqoli took during his journey, refer to Plate 6; a detailed itinerary of the places that he visited on this trip can be found in Appendix C.

\section{Narration}

Rezaqoli's travel account contains a mixture of daily personal activities and didactic arguments, and generally lacks any clear demarcation between the two. Interestingly, in the opening chapters of his journal, which is devoted to Iran's recent history, Rezaqoli applies a passive voice, as if to conceal his authorial presence and make his claims more objective. Soon, however, as the discussion turns to his own travels, the author begins to appear as a presence through the increasing use of first-person narration.

Except for a few instances, Rezaqoli does not communicate the sources of his information. From the writing of Fraser, we understand that his translator, Kayat, was in charge of gathering most of the facts that Rezaqoli sought. As Fraser suggests, Rezaqoli spent his forenoons writing his journal. ${ }^{90}$ In much of the narrative it seems apparent that Rezaqoli is writing on the spot and during short intervals. ${ }^{91}$ Similar to Abolhasan, he left blank spaces in portions of his manuscript, hoping that he could later fill in these gaps with more accurate information. For example, when discussing an art gallery in London, Rezaqoli left a space in which he intended to go back and insert the name of the artist, which he never did. ${ }^{92}$ It also appears that sections of the writing added in the book's margins (traditionally called hashieh nevisi) were composed later and sometimes with a different handwriting. ${ }^{93}$

Rezaqoli appears to be obsessed with the elegance of his writing, and he applies an overelaborate style which stands out even when compared against other travelogues of his time, and particularly in relation to Mirza Saleh's direct and unadorned prose. His sentences frequently include rhymes or semi-rhymes, with an abundant embellishment of metaphors, poetry, and Arabic verses that seem more intended to exhibit his mastery of literary devices than to convey any particular meaning. On several occasions, Rezaqoli reminds the readers of his accomplishments in poetry through stories of his literary discussion with others. ${ }^{94} \mathrm{He}$ presents himself as a poet, well acquainted with Iran's history and literature, for example by analyzing the Persian collection in the library of the East India Company, and by commenting on Mirza Ebrahim Shirazi's translation of a history book. ${ }^{95}$

Rezaqoli adorns his writing with verses from the Quran and incorporates more than a hundred couplets of poetry from 15 literary paragons, such as Sa'di, Hafez, and Ferdowsi, as well as less popular poets such as Naziri-Neyshaburi, Kamaloddin Esma'il, and Asheq-Esfahani. He occasionally includes his own poems, as well as some of Vali's. Rezaqoli's adoptions of poetry usually occur when he writes about European women. His use of poetry to describe space is limited to natural landscapes; seldom does he 
romanticize built environment in the same manner. Impressed by a landscape outside of Beirut, Rezaqoli appropriates the following words from Hafez:

Myriad besotted eyes caress my sight in the city:

I'm tippled with no need to drink any wine.

Lavished full with flirtatious nymphs from six directions;

Poverty prevents me, though I'm a costumer of all six directions! ${ }^{96}$

The poetic tone of Rezaqoli's safarnameh sometimes borders on a glorification of Europe. As will be discussed in more detail later, his romantic longing for heavenly space, landscape, women, and wine is re-inscribed directly from ideals fashioned in Persian poetry and Islamic texts.

\section{Fictionality}

Fraser suggests that Rezaqoli "evinced a greater desire to see the useful objects of interest in the country, than those merely calculated to afford amusement." 97 Yet, he writes about the "amusing" objects of Farangestan no less than the "useful" ones. His travelogue is filled with heroic stories and funny anecdotes. The book's success in entertaining its readership is most certainly related to its author's delightful character. His companions seemed to enjoy his anecdotes; in once occasion Princess Victoria of England "almost fainted of laughter," upon hearing one of Rezaqoli's stories. ${ }^{98}$ Rezaqoli masterfully adopted many storytelling techniques of fiction to entertain his readers. His character descriptions include entertaining details such as notations of their Persian accents. ${ }^{99}$

Rezaqoli narrates his stories so masterfully that it is hard to determine whether his stories are his personal firsthand experience or he is reporting on events that his companions experienced. Teymur's independent visit to Cádiz, and Vali's first trip to London, for example, are described with a passive tone so that the reader cannot clearly identify the narrator. ${ }^{100}$

In the stories told by Rezaqoli, the adventuring brothers are almost always at the center of events. This pattern fades as the travelogue develops, and the wonders of Europe replace the tales of the brothers fighting under extreme cannon fire, being surrounded by thirty enemy horsemen and escaping the blockade, almost freezing to death under severe snow, fighting off bandits, being attacked by a giant hog, undergoing extreme thirst and drinking from sewage water in which two dead jackals were decomposing, dueling with an Arab thief, shooting an asp, getting lost in the desert, getting stuck in a swamp, and being overwhelmed by a storm while sailing toward England. ${ }^{101}$ Though I could not find any evidence that would falsify Rezaqoli's claims, a certain amount of skepticism about these anecdotes is probably warranted.

Rezaqoli's obsession in weaving a flattering and entertaining narrative may sometimes have lead him to take liberties with the facts, especially when they relegated his personal character as a noble and highly respected 
persona. He pretends in the travelogue that he does not consume alcohol, but Fraser relates that all of the brothers were rather fond of drinking. ${ }^{102}$

\section{Significance}

Unlike its English translation published in 1839, Rezaqoli's safarnameh did not receive a wide readership in its time; it was however read by other notables, and it has since become an important source for studying the history of Iran. ${ }^{103}$ The book includes an elaborate explanation of the political intrigues and conflicts that took place within the country between the death of Fath-Ali Shah in 1834 and the assassination of Qa'emmaqam in 1835. Rezaqoli's explanation of these events is supplemented by his detailed discussions of modern institutions in Europe and his interactions with high-ranking British officials, including Princess Victoria of England.

For the purposes of this study, Rezaqoli's memoir is particularly notable because it can be compared against the diaries of Kayat and Fraser, who accompanied the princes in their voyage and often described the same phenomena. ${ }^{104}$ Examining these parallel descriptions allows for a strong comparative analysis of Rezaqoli's spatial experiences and his perceptions of Western modernity.

\section{Farrokh-Khan}

Aminoddowleh Abu-Taleb Farrokh Khan Ghaffari (1812-1871) was a high-ranking official in the Qajar court (see Figure 2.3). He served as the governor of Gilan in 1839, the governor of Kashan in 1857, minister in attendance in 1858 , minister of the interior in 1859 , member of the Royal Council in 1859, and member of the Council of the State and minister of the court in 1866. In his role as Ilchi-e kabir (the grand ambassador), FarrokhKhan was sent to the French court of Napoleon III in 1855, where he helped to resolve political conflicts with Britain and negotiate an Anglo-Iranian peace treaty, known as the Treaty of Paris.

During his diplomatic mission, which took more than two years, Farrokh-Khan charged his secretary, Hoseyn Sarabi, to help him prepare a diary of the travels. This memoir was not published at the time, but it was read by the Qajar Shah and other members of the Persian court, and it later became a significant document for historians interested in the international politics of the era. Farrokh-Khan's descriptions of diplomatic efforts and his interactions with Western notables, such as Napoleon III, King Leopold I, and Queen Victoria, have provided valuable source material for scholars. However, the travelogue seldom has been mined for its broader descriptions of Western spaces and social/cultural perceptions, which is the focus in this current study. To see the route that Farrokh-Khan took during his journey, refer to Plate 7; a detailed itinerary of the places that he visited on this trip can be found in Appendix D. 


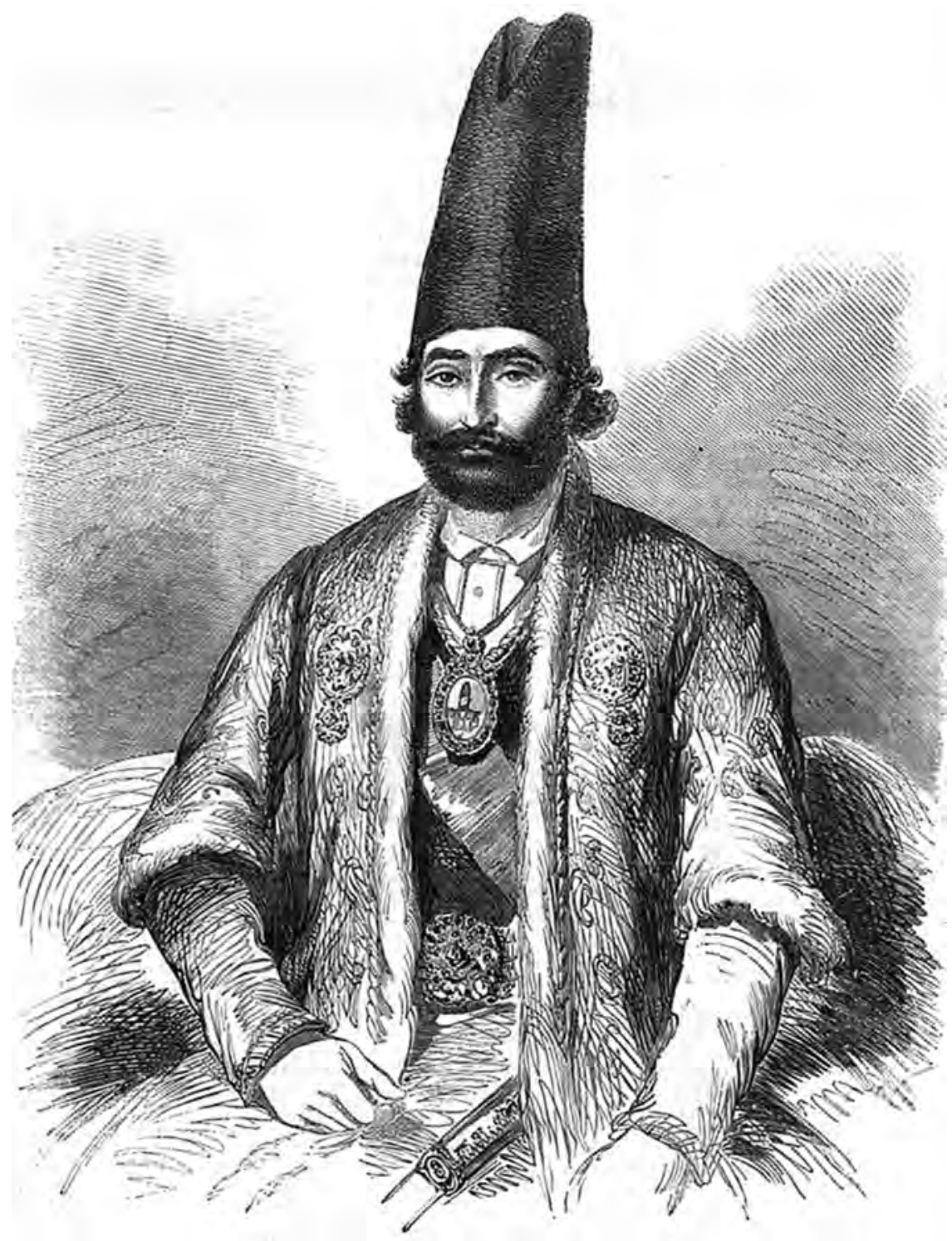

Figure 2.3 Farrokh-Khan Aminoddowleh, engraved in 1857 from a Persian miniature. Source: Illustrated London News.

\section{Format}

Farrokh-Khan's memoir incorporates many of the standard conventions of the safarnameh genre, yet the political documents and commentary included 
in his book set it apart from other travel memoirs. In a letter addressed to Farrokh-Khan, his secretary Hoseyn Sarabi requested funding for publishing the memoir in Tabriz, Iran, confirming that the ambassador originally intended that at least parts of this work would be distributed to a wide readership. ${ }^{105}$ The primary audience of the book was the nobility and the Shah himself, who received the work within a diplomatic context. Because of this, Farrokh-Khan had to avoid many topics and to follow certain codes of social decorum, for example by incorporating the occasional passages of praise for the Shah that are interspersed at seemingly random locations throughout the text.

In contrast to other travelogues of the time, Farrokh-Khan's memoir makes almost no mention of activities that would be considered improper in his culture. There is no talk about prostitution, no attempt to eroticize women and their relationship either to the author or to other men, and almost no mention of alcohol, except when a toast was made in the honor of the Shah. Given the close observation and detailed descriptions of other matters in the memoir, it seems unlikely that this silence is accidental. The concealment of issues that fascinated most other travelers is probably best explained by Farrokh-Khan's prominent position in the court and his need to avoid the hint of scandal. In addition, the text's obsession with propriety hints at its author's intention to bypass censorship when publishing the book - an effort that eventually fell short. Ironically, the justification given by the grand vizier, Mirza Agha Khan Nuri, to ban the book further confirms its significance. Once he learned of Farrokh-Khan's determination to publish, Nuri sent a letter warning the ambassador against doing so:

I have heard that Hoseyn Sarabi, the secretary of the grand ambassador, has written a book, under your supervision, about the details of your trip to Europe, and that he intends to publish it in Tabriz. I should remind you that during his mission, Saif el-Mulk also decided to publish a similar book with the objective to educate people on the differences between the state of affairs in Iran and Europe, with which I disagreed. Certainly, you should not allow Hoseyn Sarabi to publish this book and distribute it all over. This will cause public awareness about Europe which is not appropriate. ${ }^{106}$

In addition to moral qualms, it seems likely that the officials of the court were concerned about the development of any "public awareness" of Farangestan that might seem to confirm Iran's backwardness and contribute to skepticism about the power of the regime.

\section{Narration}

The narration of this travel account cannot simply be considered as Farrokh-Khan's voice, as it was actually written by his secretary, Hoseyn Sarabi. Sarabi acts as a sort of ghost writer, who often refrains from offering his personal judgments in his writing, yet the extent of his influence 


\section{Modernity in a suitcase}

on the manuscript in relation to Farrokh-Khan's is unknown. It is notable that in recording the memoirs Sarabi consistently refers to Farrokh-Khan in the third person, which seems to indicate something of an external view. At the same time, parts of the memoir describe activities that Sarabi did not personally participate in, and that he could have only learned about through Farrokh-Khan's descriptions (this is the case, as an example, for Farrokh-Khan's travels in Italy and Prussia). The passages describing these events do not differ much in their style and content from the rest of the book, which may be evidence for a stronger involvement of Farrokh-Khan throughout.

Most of the book follows a day-by-day account, yet there is no evidence suggesting that the writing follows the same daily pattern. The typical format of narration in the memoir is to introduce a city; discuss general information about its population, climate, agriculture, and industry; describe the events and people encountered there by Farrokh-Khan, and then discuss any "peculiarities" that he observes. There is no mention of sources for any of the information provided in the book. Though some of the material, such as the population of a city, the budget spent on a project, or the history of a building, seems clearly derived from other documents, this factual information is simply combined in the book with Farrokh-Khan's personal descriptions and observations.

The writing style of the memoir is undistinguished in terms of rhetorical eloquence, dialogues, or stage setting. However, although its language is plain, the descriptions are vivid. Architectural discussions are secondary but still comprise a significant and previously unanalyzed part of the narrative. This discussion of European spaces is most prominent in the early portions of the book, most likely because the newness and "peculiarity" of these spaces became less striking to the travelers over time. As they gradually became more familiar with the architecture of the Other, they found its specifics to be less worthy of note.

\section{Significance}

Farrokh-Khan's travel memoir was not published until 1982. Some might argue that the document therefore has little significance in discourses of modernism, a claim that might be backed up by pointing to the text's primary goal of reporting diplomatic information. This would be an inaccurate assessment. In reality, a significant part of Farrokh-Khan's mission was to report on the state of progress in the countries he visited. Naseraddin Shah himself, who later made three journeys to Europe, was very eager to learn about Europe and personally asked his ambassadors to deliver information "about the reasons behind the wealth, progress, and success of the nation of Farangestan." 107 Even beyond this mandate, Farrokh-Khan was assigned to bring back specific modern technologies to Iran, including skilled workers and factory equipment. ${ }^{108}$ Thus, his observations of European modernity 
were both an important aspect of his mission and a source of interest to powerful notables in Iran.

Like the other memoirs discussed here, Farrokh-Khan's book provides a concrete record that was intended to accompany and support his verbal presentations to his fellow Persian elites. The oral culture was dominant in Iran at the time, and it is notable that when Farrokh-Khan (similar to Rezaqoli) addresses his audience in the memoir, he does not use the word "readers," but rather "listeners" (he uses the Arabic words same' in or mostame'in). ${ }^{109}$ This role of the memoirs as supporting documents for the active project of elite understanding and decision-making should be kept in mind when analyzing the texts. During his administrative tenure, Farrokh-Khan supervised many architectural and urban projects, most of them conducted after his return from the Europe. All these structures can be examined for direct or indirect traces of ideas reflecting the traveler's European observations.

\section{Modernity as a souvenir}

The different personalities and social positioning of the four traveler writers described in this chapter will be relevant throughout the rest of this book, as we examine their observations of Europe and the way they discussed its built environment. Their diverse backgrounds sometimes lead to contradictory images of European objects and spaces. For example, while Mirza Saleh grew so exceedingly fond of newspapers that he decided to initiate Iran's first publishing office, Abolhasan expressed an extreme suspicion of the newspaper format. As a student and scholar Mirza Saleh saw the popular press as a valuable mode of increasing public education. Abolhasan, in contrast, as an emotionally sensitive diplomat, was responding negatively to the false and sensational accounts published about him in the tabloids (for example, that his ambassadorship had been denied by Iran's monarch, that he had sired an illegitimate child with an English lady, and that he was accompanied by a female servant dressed as a man). ${ }^{110}$

Despite their differences in education, socioeconomic status, and personality, all of the travelers discussed here were young men from the higher echelons of Persian society. There are also at least two other notable qualities that they hold in common. The first, and perhaps most striking commonality, is that they all joined the Masonic lodge. Farrokh-Khan became a member of the Grand Orient of France Lodge in Paris, ${ }^{111}$ while the other three travelers joined the Freemasonry Lodge in London. It appears that all of the travelers had some prior knowledge about this fraternity and expressed a curiosity about its mysterious nature. When talking about their Masonic activities, they likewise adopt a somewhat secretive tone. Mirza Saleh, for example, says that, "It had been a while since I desired to join the Freemasons, but I never had the time. . . With Mr. Percy and Colonel D'Arcy we 
entered the Masonic lodge, had dinner, and returned around $11 \mathrm{pm}$. Writing more on this topic is not permissible." 112

Mirza Saleh was among the first Persians to be initiated into British Freemasonry, second only to Abolhasan, who became a member in 1810. Abolhasan's account of his membership is likewise quite short and understated, but mainly out of disinterest, rather than secrecy:

I spent some time riding; and in the evening I went to a meeting of freemasons as the guest of Lord Moira. He was very kind and hospitable. One of the Royal Princes, the Duke of Sussex, was there. I also became a freemason, which was highly gratifying. ${ }^{113}$

Two decades later, Rezaqoli, along with his brother Vali, joined the Lodge of Friendship of Freemasons. Rezaqoli talks freely about his desire to join this "noble, honorable, and desirable society," "114 and provides a small amount of information about the membership requirements, the significance of the fraternity, and the various degrees or rankings. Then, similar to Mirza Saleh, he tells his readers that "this is all I can say about freemasonry." 115 Vali's initiation into the society is described in Kayat's English translation of Rezaqoli's memoir, but for some reason these lines about Vali do not appear in the Persian edition of the book. ${ }^{116}$ Fraser also writes about the brothers' excitement as they anticipate their initiation, and provides a perspective on their interest:

There are few of our European institutions which allure more the curiosity of Orientals than freemasonry. Its mysterious secrecy excites their imagination, and particularly of those - a very large portion, especially in Persia-who are disposed to Soofeesm [Sufism] or freethinking in religious matters. The accounts they have received of the freemasons of Europe, magnified and probably distorted by the channels through which they reach them, dispose them to imagine that to belong to this fraternity is to obtain possession of much mystical and supernatural knowledge which is hid from the uninitiated. ${ }^{117}$

It appears that, similar to the way in which many Orientalists searched for the secret, hidden knowledge of the East, these Persian travelers likewise had a keen interest in the mystical esotericism of Farangestan.

The second quality that the Persian travelers all had in common was their appreciation and appropriation of objects that represented modernity in Europe. They each accumulated a significant collection of such objects to bring back home as evidence of Farangestan's wonders. The size and extent of the physical objects collected from Europe was quite astounding, especially given the difficulty of international travel and transport during this era. "I thought to myself," writes Mirza Saleh, once he learned that the government required his return, "other than my education, it would be nice 
if I could bring something back from this country that could benefit our government. It had been a while since it crossed my mind to take a printing device with me." ${ }^{118}$ Mirza Saleh went through an incredible amount of effort and hardship to convey an entire printing press back to Iran in workable condition, including covering the purchase costs and receiving technical training for its use and maintenance. ${ }^{119}$

The items that Abolhasan brought back were mostly gifts from the British government and the East India Company, including "glass, mirrors, broadcloth, stationery, guns, and pistols," plus a few small personal items that Abolhasan purchased himself, such as "portable bedsteads, dining tables, elegant chairs, dressing-stands, sideboards, and chair-beds," as well as silverware, paper supplies, stationary, books, maps, journals, desks, and cartography tools. ${ }^{120}$ Abolhasan additionally mentions gifts that he received from his friends, such as a clock, a ring, a pen-case, a dagger, muskets, and telescopes. ${ }^{121}$ As it turns out, a large portion of these items were "accepted" by the Shah as tribute upon the ambassador's return:

[Abolhasan] came laden not only with presents he had received but with an immense quantity of merchandize, purchased in Europe.... [The baggage was] lodged in one of the royal warehouses as presents for his majesty. . . . The unhappy diplomatist never received back, or dared to claim a single package. ${ }^{122}$

There is a significant difference between the items that Abolhasan collected from Europe and those he obtained from other locations in his travels. As the British press noted, Abolhasan's focus in England was directed on practical objects representing the material culture of the West, ${ }^{123}$ while the items that grabbed his attention during his travels across India and the Middle East were mostly ornamental or pleasure-related, to say the least. ${ }^{124}$

A similar preference towards "articles of general utility" was displayed by the other travelers. Rezaqoli and his brothers, according to Fraser, expressed "a wish to see rather some of our more useful institutions than trivial exhibitions and amusements, which leave little impression, and lead to no improvement." ${ }^{125}$ Rezaqoli, as Fraser observed, "appeared constantly on the watch for useful information, as if he still entertained the hope that one day or other he might again be in position to turn it into account." ${ }^{126}$ Fraser was right: from the first day that Rezaqoli set foot in England, he was determined to bring back a particular device - one which he quite perceptively assumed would have a great impact on his society: the water pump. ${ }^{127}$

Farrokh-Khan, due to his powerful position in the court, enjoyed the opportunity to acquire, transport, and implement the European technology that he fancied most - the telegraph. During his travels he arranged with a Paris manufacturer to have the necessary apparatus transported to Iran and installed. ${ }^{128}$ 
The items that the travelers brought back mainly served as representations of European technology. When the capacity of an object was insufficient to capture and transfer this technology, the travelers, especially the more illustrious ones, tried to import technicians along with their material souvenirs. Abolhasan, for example, attempted to recruit glass workers to return with him to Iran. ${ }^{129}$ Farrokh-Khan engaged a French photographer, Francis Carlhian, who worked for the court in Tehran for several years, instructing local craftsmen in his trade. ${ }^{130}$ Mirza Saleh, who could not afford to make similar offers to European technicians, had to undergo training to learn how to operate and maintain his printing press.

In all of these efforts, the travelers evinced an attitude of studious interest in European knowledge and technology. They collected and analyzed whatever they witnessed in Farangestan in intense detail, as though they were committed to breaking the codes of modernity and reassembling it in Iran through an indigenous reverse engineering. This attitude was widely shared by later travelers, most notably Naseraddin Shah, who became "renowned for his enthusiastic purchase of Western artifacts and his absorption of architectural styles during his European travels." ${ }^{131}$ After assuming the throne in 1848, Naseraddin Shah collected many artifacts from his trips to Europe, including a large mechanical clock that he affixed to the tower of his palace. This interest that the travelers showed in new modern technology in Iran was never submissive, but rather selective and thoughtful. When explaining the concept of the clock, Rezaqoli cautiously suggests,

The Farangi system is seemingly better than the calculation of time based on sunrise and sunset, because day and night change during different seasons, while midnight and midday remain fixed. Now that they have invented this technology, it is best to adopt it. ${ }^{132}$

Overall, the Persian elite during this time period seem to have been captivated by an intense interest in the mysteries of European knowledge and culture, whether that was the esoteric mysteries of the Freemasons, or the technical mysteries of the mechanical clock. They sought to participate in these mysteries and incorporate them as adornments in their own culture. Of course, the Farangi accomplishments that the travelers could implement were only a small fraction of those they saw and fancied. The remainder was recorded in the safarnamehs for possible future implementation, either by the travelers or by their readers. The travel memoirs themselves can be seen in this light, as a kind of instruction manual to European progress. They provided a holistic narrative coherence to the otherwise narrow and focused understanding of Europe that the souvenirs offered. In this context, the travel memoirs gain significance not only as personal journals, but also as practical to-do lists towards progress, user guides towards modernity, and road maps towards a desired future. 


\section{Notes}

1 Rezaqoli Mirza, Safarnameh, 691.

2 Journal of a Residence, 123.

3 Mostafa Afshar, Safarnameh-Ye Khosrow Mirza; Mohammad Moshiri, Sharh-E Mamuriyat-E Ajudanbashi.

4 Mirza Saleh Shirazi, Majmueh Safarnameha, 180, 181, 274-276, 338, 352.

5 Rezaqoli Mirza, Safarnameh, 317, 318. Farrokh-Khan Aminoddowleh, Makhzanol Vaqaye', 264, 265, 273, 285, 288, 290, 292, 293, 304, 306, 307, $309,312$.

6 For more details about Abolhasan's life, see Hasan Javadi, “Abu'l-Hasan Khan İlč $\bar{I}$; James Justinian Morier, A Journey through Persia, 221-223; Abolhasan Ilchi, A Persian at the Court, 17-19.

7 Ilchi, Heyratnameh; Ilchi, A Persian at the Court.

8 Heyratnameh, 48.

9 For an example of material that was later inserted into the text, see Margaret Morris Cloake, "Foreword and Footnotes," 83. where the editor explains the confusion in the footnotes.

10 Ilchi, Heyratnameh, 49.

11 Morier, A Journey through Persia, 355.

12 Ilchi, Heyratnameh, 90-94, 135, 138, 145, 166-169, 186.

13 One example of Abolhasan's mistrust in the information he receives is when reporting on his visit to a cannon manufactory in Woolwich; there he writes, "I asked the General [William Congreve] how many cannon balls he had. He said 50,000; but I estimated there were 30,000" (A Persian at the Court, 260).

14 Heyratnameh, 229.

15 A Persian at the Court, 83.

16 Heyratnameh, 147.

17 British Library, "Papers of the Marquis Wellesley," f.204.

18 Ilchi, Heyratnameh, 208, 324; see also James Justinian Morier, A Second Journey through Persia, 2.

19 A Second Journey through Persia, 402.

20 Ilchi, A Persian at the Court, 210, 271.

21 Morier, A Journey through Persia, 223; Hasan Morsalvand, "Introduction," 38.

22 Ilchi, A Persian at the Court, 52, 60; Heyratnameh, 244, 245, 247, 351.

23 Heyratnameh, 48.

24 A Persian at the Court, 78.

25 Heyratnameh, 247.

26 Ilchi's other portrait by Sir William Beechey is entitled "Mirza Abu'l Hassan Khan" and can be found at the British Library, India Office Library and Records. Thomas Lawrence's painting of Ilchi is held at Harvard Art Museums/Fogg Museum, bequest of William M. Chadbourne.

27 See Ilchi, A Persian at the Court, 181; Heyratnameh, 151, 238, 239.

28 A Persian at the Court, 109, 113, 180; Heyratnameh, 218.

29 Cited in Cloake, "Foreword and Footnotes," 77.

30 Abolhasan's friends described him as a "fat jolly old fellow, always laughing" (William Richard Holmes, Sketches on the Shores of the Caspian, 366; see also Morier, A Journey through Persia, vi).

31 James Baillie Fraser, Narrative of a Journey into Khorasan, 150.

32 Ilchi, A Persian at the Court, 177.

33 James Justinian Morier, "The Mirza Abul Hassan,” 301.

34 Ilchi, A Persian at the Court, 269.; Heyratnameh, 222, 237.

35 A Persian at the Court, 97.

36 Ibid., 294. Heyratnameh, 317. 
37 In response, Abolhasan notes that the short wigs that Western dukes wear resemble sheep's fleece (Heyratnameh, 247).

38 The Mirza Firouz character, in the novel, was directly modelled on Abolhasan, while the story's hero, Hajji Baba, was indirectly inspired by his personality (see James Justinian Morier, The Adventures of Hajii Baba).

39 For a discussion of this text and its popularity, see Abbas Amanat, "Hajji Baba of Ispahan.”

40 Ibid.

41 Ilchi, Heyratnameh, 362.

42 As Morier observed, Abolhasan's “journal, which he regularly kept, during his absence from Persia. . . was read with great avidity by his own countrymen" (Morier, "The Mirza Abul Hassan,” 301; also see Denis Wright, “A Persian at the Court of King George").

43 Abolhasan also kept a journal during his trip to Russia, which is published under the following title: Abolhasan Ilchi, Safarnameh-Ye Mirza Abolhasan.

44 Morier, A Second Journey through Persia, 18; Fraser, Narrative of a Journey into Khorasan, 150.

45 Morier, for example, mentions how the Persian ambassador to Bonaparte, "entered us with an account of Farangistoun [Farangestan]. He expatiated with seeming ecstasy on everything which he had seen" (Morier, A Journey through Persia, 195).

46 "La Belle Assemble."

47 When writing about his mission and his travels, Abolhasan states, "they are recorded here because it is my hope that this journal will prove to be a useful guide for future ambassadors" (Ilchi, Heyratnameh, 63).

48 A Persian at the Court, 123.

49 Morier, A Journey through Persia, 356.

50 Another sculpture, located at the Albert Memorial in Kensington Gardens, London, is often associated with Mirza Saleh. Four groups of monuments in the garden represent Europe, Asia, Africa, and the Americas. According to some scholars, including Yahya Zaka, who has written a preface to Mirza Saleh travel diary, one statue among the Asian group is modelled on Mirza Saleh's countenance (Yahya Zaka, "Majmueh Safarnameha"). This is a questionable assumption, however. The sculpture was designed by John Henry Foley (1818-1874), not by Robert William Sievier (1794-1865) as Zaka suggests. Foley was only 12 years old when Mirza Saleh made his journey. The monument in question was not commissioned until May of 1868, four decades after Mirza Saleh had left England.

51 Nile Green, The Love of Strangers, 310.

52 Fereydoun Adamiyat, Fekr-E Azadi.

53 William Price and Mirza Saleh Shirazi, A Grammar of the Three Principal Oriental Languages, vi. For further explanations on Mirza Saleh's role in nineteenthcentury Oriental scholarship, see Tavakoli-Targhi, Refashioning Iran, 32.

54 Willem Floor, “Čāp.” For more information, see Nile Green, "Paper Modernity?”

55 Shirazi, Majmueh Safarnameha, 186.

56 Ibid., 147.

57 Mirza Saleh planned the two-part structure of his writing early in his trip, when he writes, "first I write about the condition and events of the city and then I proceed to my personal ruzaneh" (ibid., 108).

58 Ibid., 104.

59 Ibid., 177.

60 Mirza Saleh writes: "I find it more advantageous to write as much as I can on introducing the city, its origins, and people's customs and traditions so that the people who read it can benefit from it" (ibid., 108). 
61 Ibid.

62 Ibid., 193.

63 Ibid., 78, 85.

64 Ibid., 181. For another example, see ibid., 141.

65 Ibid., 266.

66 Ibid., 78.

67 Ibid., 402.

68 Some examples of Mirza Saleh's citations of other authors can be seen in ibid., $1,58,68,85,141,194,399,419$. Citations of his traveling companions can be seen in ibid., 114, 115, 181, 396, 403.

69 Ibid., 23, 25, 26.

70 Ibid., 115.

71 Ibid., 101.

72 Ibid., 74, 112, 187.

73 Ibid., 102. See also p. 372 for another example.

74 See, for example, Rezaqoli Mirza, Safarnameh, 336, 341.

75 Shirazi, Majmueh Safarnameha, 63. For another example, see p. 114.

76 Ibid., 260.

77 Ibid., 16.

78 Ibid., 284, 337.

79 An English translation of excerpts of his travel diary was published in 1824. The publication history of Mirza Saleh's work is discussed in Tavakoli-Targhi, Refashioning Iran, 44.

80 Green, The Love of Strangers, 19.

81 Javad Tabatabai, Dibachahi Bar Nazariyah-I Inhitat-I Iran (an Introduction to the Theory of Decadence in Iran), 268-269.

82 Rezaqoli Mirza, Journal of a Residence.

83 Assaad Y. Kayat, A Voice from Lebanon, 110; Rezaqoli Mirza, Journal of a Residence, $\mathrm{x}$.

84 Elsewhere, he compliments Rezaqoli on his "charm of sweetness and of dignity. . . which secured him affection as well as respect from those of any feeling around him" (James Baillie Fraser, Narrative of the Residence, 20, 29, 128).

85 Ibid., 20.

86 Kayat, A Voice from Lebanon, 110.

87 According to Fraser, Teymur was "blessed with a fine temper, and a high and buoyant spirit, which, though sometimes breaking out into momentary blaze of passion, renders him a cheerful animated companion" (Fraser, Narrative of the Residence, 24, 94; see also Kayat, A Voice from Lebanon, 110; Rezaqoli Mirza, Journal of a Residence, $\mathrm{x}$ ).

88 Journal of a Residence, $\mathrm{x}$.

89 Fraser, Narrative of the Residence, 21.

90 Ibid., 130.

91 Rezaqoli Mirza, Safarnameh, 193.

92 Ibid., 390.

93 According to the book's editor, Asghar Farmanfarmai Qajar, the handwriting belongs to Vali (Asghar Farmanfarmai Qajar, "Footnotes," 173).

94 Rezaqoli Mirza, Safarnameh, 151, 406, 435.

95 Ibid., 472, 485.

96 Hafez, The Poems of Hafez, 136. Rezaqoli Mirza, Safarnameh, 269.

97 Fraser, Narrative of the Residence, 244.

98 Rezaqoli Mirza, Safarnameh, 444.

99 See ibid., 155.

100 Ibid., 336, 352-371.

101 Ibid., 87, 90, 94, 191, 194, 208, 211, 252, 261, 288. 
102 Ibid., 206.

103 Apparently, Iran's current Supreme Leader, Seyyed Ali Khamenei, had read Rezaqoli's diary early after its reprint and recommended the book to others (Abdollah Shabazi, "Mir-Hossein Mousavi”).

104 Kayat, A Voice from Lebanon.; Fraser, Narrative of the Residence.

105 Iraj Afshar, "Bahsi Dar Asnad," 25.

106 Ibid., 62.

107 Aminoddowleh, Makhzanol Vaqaye’, 267.

108 When visiting an iron foundry in Liège, Belgium, Farrokh-Khan emphasizes this important part of his mission by declaring, "in this mission, I have been granted full responsibility to send as many technicians and factory equipment as possible to Iran" (ibid., 311).

109 Ibid., 215, 216, 285; Rezaqoli Mirza, Safarnameh, 488.

110 Ilchi, Heyratnameh, 147, 159, 172, 333; A Persian at the Court, 206, 276.

111 Aminoddowleh, Makhzanol Vaqaye'.

112 Shirazi, Majmueh Safarnameha, 176.

113 Ilchi, A Persian at the Court, 265.

114 Rezaqoli Mirza, Safarnameh, 444.

115 Journal of a Residence, 124. See also Safarnameh, 444.

116 In Kayat's translation we read, "Wali [Vali] joined the Freemason Society, having beforehand written a request to the head of the Society for his reception, and to-day (Thursday) they hold their monthly meeting, and Wali took his first degree" (Journal of a Residence, 287).

117 Fraser, Narrative of the Residence, 231, 232.

118 Shirazi, Majmueh Safarnameha, 344.

119 Ibid., 345, 418.

120 Cloake, "Foreword and Footnotes," 264. "The Persian Ambassador." Morsalvand, "Introduction."

121 Ilchi, A Persian at the Court, 113, 249, 269, 274, 288.

122 Fraser, Narrative of a Journey into Khorasan, 151, 152.

123 In the Morning Herald we read, "In England, his attention has been chiefly directed to our useful inventions. He has constantly preferred articles of general utility, to those made for ornament or show" ("The Persian Ambassador"; emphasis added).

124 For example, in Istanbul's slave market, Abolhasan purchased a beautiful female servant who became known in the British press as the "fair Circassian" (cited in Cloake, "Forward and Footnotes," 110).

125 Fraser, Narrative of the Residence, 250.

126 See ibid., 244. Rezaqoli's never-realized fantasy to regain his power and implement Farangi achievements was not limited to European technology - it also included institutions. Fraser, who observed Rezaqoli's curiosity in senior living facilities, writes: "[He] seemed to think that, if ever he were in power again, it would be one of the things he should wish to imitate" (ibid., 12).

127 In his memoir, Rezaqoli writes:

We visited a manufactory for the purpose of purchasing some instruments, and a pump, which is capable of drawing water from the depth of seventy draas. This latter I bought for 200 tomans, to be used on our return to the Holy Land.

(Rezaqoli Mirza, Journal of a Residence, 88)

128 An article in The Times, dated 1858, reads: "Feruk Khan [Farrokh-Khan], the Persian Ambassador, has ordered from a Paris manufacturer the apparatus necessary for the establishment of an electric telegraph in Persia" ("Express from Paris") 
129 In his memoir, Abolhasan writes, "I told my friends that the Shahanshah [literally, king of kings] of Iran is very interested in technicians, and particularly appreciates glassworks. Should the master-enameller agree to travel to Iran with us, it would be of his great pleasure" (Ilchi, Heyratnameh, 184).

130 There is some debate among scholars as to whether Carlhian was actually recruited by Farrokh-Khan in France and travelled back to Iran with him, or whether Carlhian came to Iran independently and was engaged by Farrokh-Khan after his return from the Europe (see Katia Salmasi, "SayehEi Dar Akkasi," 222; also see Mohammad Hasan Khan Etemadossaltaneh, Mer'atolboldan Naseri, 3).

131 Talinn Grigor, “Orient Oder Rome?” 587.

132 Shirazi, Majmueh Safarnameha, 568.

\section{References}

Adamiyat, Fereydoun. Fekr-e Azadi Va Moqaddameh-Ye Nehzat-E Mashrutiyyat [the Idea of Freedom and Introduction to the Constitutional Revolution]. Selseleh Ketabhay-e Tarikhi. Tehran: Entesharat-e Sokhan, 1961.

Afshar, Iraj. "Bahsi Dar Asnad-e Marbut Beh Farrokh Khan [Discussion About Documents Related to Farrokh Khan]." In Makhzan Al-Vaqayi: Safarnameh-Ye Farrokh Khan-e Aminoddowleh [Aminoddowleh's Travelogue], edited by F. Ghaffari and Majmu'eh Safarnamehha-Ye Irani, 586. Tehran: Asatir, 1994.

Afshar, Mostafa. Safarnameh-Ye Khosrow Mirza Beh Sanpeterzburg [Khosrow Mirza's Travel to Saint Petersburg]. Tehran: Ketabkhaneh-ye Mostowfi, 1970.

Amanat, Abbas. "Hajji Baba of Ispahan." In Iranica, edited by Ehsan Yarshater, 561-568. New York: Columbia University, 2003.

Aminoddowleh, Farrokh-Khan. Makhzanol Vaqaye': Safarnameh-Ye Farrokb Khan$e$ Aminoddowleh [Aminoddowleh's Travelogue]. Majmu'eh Safarnameha-Ye Irani. 2nd ed. Tehran: Asatir, 1994.

British Library. "Papers of the Marquis Wellesley."

Cloake, Margaret Morris. "Foreword and Footnotes." Translated by Margaret Morris Cloake. In A Persian at the Court of King George: The Journal of Mirza Abul Hassan Khan. London: Barrie \& Jenkins Ltd, 1988, 7-12.

Etemadossaltaneh, Mohammad Hasan Khan. Mer'atolboldan Naseri [in Persian]. 4 vols. Vol. 3. Tehran: Asfar, 1985.

"Express from Paris." Times, February 51858.

Farmanfarmai Qajar, Asghar. "Footnotes." In Safarnameh-Ye Rezaqoli Mirza Navey-Ye Fath Ali Shah [the Travel Account of Rezaqoli Mirza, Fath Ali Shah's Grandson]. Tehran: Asatir, 1994.

Floor, Willem. “Čāp.” In Iranica, edited by Ehsan Yarshater, 760-764. London and New York: Routledge \& Kegan Paul, 1990.

Fraser, James Baillie. Narrative of a Journey into Khorasan, in the Years 1821 and 1822 Including Some Account of the Countries to the North-East of Persia; with Remarks Upon the National Character, Government, and Resources of That Kingdom. London: Longman Hurst Rees Orme Brown and Green, 1825.

. Narrative of the Residence of the Persian Princes in London, in 1835 and 1836. The Middle East Collection. New York: Arno Press, 1973.

Green, Nile. "Paper Modernity? Notes on an Iranian Industrial Tour, 1818." Iran 46 (2008): 277-284. 
The Love of Strangers: What Six Muslim Students Learned in Jane Austen's London. Princeton, NJ: Princeton University Press, 2015.

Grigor, Talinn. “Orient Oder Rome? Qajar 'Aryan' Architecture and Strzygowski's Art History.” Art Bulletin LXXXIX, no. 3 (2007): 28.

Hafez. The Poems of Hafez. Translated by Reza Ordoubadian. Bethesda, MD: Ibex Publishers, 2006.

Holmes, William Richard. Sketches on the Shores of the Caspian: Descriptive and Pictorial. London: R. Bentley, 1845.

Ilchi, Abolhasan. Heyratnameh: Safarnameh-Ye Mirza Aolhasan Khan-e Ilchi Beh Landan [Wonderlogue: The Accounts of Ambassador Abolhasan Khan's Travel to London]. 1st ed. Tehran: Moasseseh-ye Khadamat-e Farhangi-ye Rasa, 1986.

- A Persian at the Court of King George: The Journal of Mirza Abul Hassan Khan. Translated by Margaret Morris Cloake. London: Barrie \& Jenkins Ltd, 1988.

- Safarnameh-Ye Mirza Abolhasan Khan Shirazi Beh Rusiyeh: Dalil as-Sufara [Abolhasan Khan's Travel Memoir of Russia]. Tehran: Donya-ye Ketab, 1984.

Javadi, Hasan. "Abu'l-Ḥasan Khan Īlč̄̃: Persian Diplomat, B. 1190/1776 in ŠĪrāz.” In Encyclopedia Iranica, edited by Ehsan Yarshater, 308-310. New York: Columbia University Press, 1983.

Kayat, Assaad Y. A Voice from Lebanon with the Life and Travels of Assaad Y. Kayat. London: Madden \& Co., 1847. Texto impreso.

"Memoirs of the Persian Ambassador." La Belle Assemble: Or Court and Fashionable Magazine, June 1819, 2.

Morier, James Justinian. The Adventures of Hajii Baba, of Ispahan. London: R. Bentley, 1851.

- A Journey through Persia, Armenia, and Asia Minor, to Constantinople, in the Years 1808 and 1809: In Which Is Included, Some Account of the Proceedings of His Majesty's Mission, under Sir Harford Jones . . To the Court of the King of Persia. London: Printed for Longman, Hurst, Rees, Orme, and Brown . . . 1812.

- "The Mirza Abul Hassan." In The Adventurer of the 19th Century, Issues 1-37, 298-301. Knight and Lacey, 1823.

- A Second Journey through Persia, Armenia, and Asia Minor, to Constantinople, between the Years 1810 and 1816: With a Journal of the Voyage by the Brazils and Bombay to the Persian Gulf: Together with an Account of the Proceedings of His Majesty's Embassy under His Excellency Sir Gore Ouseley. London: Longman, Hurst, Rees, Orme, and Brown, 1818.

Morsalvand, Hasan. "Introduction." In Heyratnameh: Safarnameh-Ye Mirza Aolhasan Khan-e Ilchi Beh Landan [Wonderlogue: The Accounts of Ambassador Abolhasan Khan's Travel to London]. Edited by Hasan Morsalvand. Tehran: Moasseseh-ye Khadamat-e Farhangi-ye Rasa, 1986, 11-44.

Moshiri, Mohammad. Sharh-e Mamuriyat-e Ajudanbashi [Ajudanbashi's Mission]. Tehran: Ashrafi, 1968.

“The Persian Ambassador." The Morning Herald, June 271810.

Price, William, and Mirza Saleh Shirazi. A Grammar of the Three Principal Oriental Languages, Hindoostanee, Persian, and Arabic, on a Plan Entirely New, to Which Is Added, a Set of Persian Dialogues. London: Kingsbury, Parbury, and Allen, 1823.

Rezaqoli Mirza. Journal of a Residence in England, and of a Journey from and to Syria, of Their Royal Highnesses Reeza Koolee Meerza, Najaf Koolee Meerza, 
and Taymoor Meerza, of Persia, to Which Are Prefixed Some Particulars Respecting Modern Persia, and the Death of the Late Shah. Translated by As'ad Yakub Khayyat. London, Westmead: W. Tyler, Gregg Inter, 1839.

- Safarnameh-Ye Rezaqoli Mirza Navey-Ye Fath Ali Shab [the Travel Account of Rezaqoli Mirza, Fath Ali Shab's Grandson]. Majmueh Safarnameha-Ye Irani. Edited by Asghar Farmanfarmai Qajar. 3rd ed. Tehran: Asatir, 1994.

Salmasi, Katia. "Sayeh-Ei Dar Akkasi-Ye Iran [a Shadow in Iranian Photography]." Bokhara no. 35 (2004): 10.

Shabazi, Abdollah. "Mir-Hossein Mousavi Anguneh Keh Man Shenakhtam: Beh Bahaneh-Ye Didar-e Akhiram Ba Mohandes Mousavi [Mir-Hossein Mousavi as I Knew Him]." In Yaddasht-ha-ye Parakandeh, 2009, http://www.shahbazi.org/ blog/Archive/8712.htm.

Shirazi, Mirza Saleh. Majmueh Safarnameha-Ye Mirza Saleh Shirazi [Series of Travelogues by Mirza Saleh Shirazi]. Nashr-e Tarikh-e Iran. 1st ed. Tehran: Nashr-e Tarikh-e Iran, 1985.

Tabatabai, Javad. Dibachahi Bar Nazariyah-I Inhitat-I Iran [an Introduction to the Theory of Decadence in Iran]. Andishah-I Siyasi 2. Chap-i 1st ed. Tehran: Nigah-i Muasir, 1380.

Tavakoli-Targhi, Mohamad. Refashioning Iran: Orientalism, Occidentalism, and Historiography. St. Antony's Series. New York: Palgrave, 2001.

Wright, Denis. "Introduction." Translated by Margaret Morris Cloake. In A Persian at the Court of King George: The Journal of Mirza Abul Hassan Khan, 13-21. London: Barrie \& Jenkins Ltd, 1988.

Zaka, Yahya. "Preface." In Majmueh Safarnameha-Ye Mirza Saleh Shirazi [Series of Travelogues by Mirza Saleh Shirazi], 488. Edited by Gholam-Hosein Mirza-Saleh. Tehran: Nashr-e Tarikh-e Iran, 1985, 11-29. 


\section{When worlds collide}

Oh, East is East and West is West, and never the twain shall meet Till Earth and Sky stand presently at God's great Judgment Seat; But there is neither East nor West, Border, nor Breed, nor Birth, When two strong men stand face to face, tho' they come from the ends of the earth! ${ }^{1}$

\section{Verbalizing space}

The travel memoirs that are analyzed in this book demonstrate an interesting lack of an established vocabulary when describing space, as indicated in the writers' clumsy word choices and circuitous explanations. The direct descriptions they provide of European spaces are usually limited to statements about the size, materials, and cleanliness of the buildings and urban spaces they experienced. This inability to describe the quality of a space was due in part to the void of critical attention to architectural space in Persian literature. This underdevelopment of an established architectural lexicon in the Persian language urged the travelers to frequently rely on a quantitative approach. Their constant measurement of spaces, such as the size and number of different architectural elements, is indicative of their attempts to accurately describe the spaces they were seeing, despite the broader inadequacies of language.

In general, as the travelers move toward the end of their trips, their spatial descriptions begin to shift towards a more diverse set of analytical tools. For example, Mirza Saleh abandons his frequently used polar and reductionist categorization of cities as either kharab or abad (ruined or thriving). ${ }^{2}$ Similarly, Rezaqoli, who uses only the word ba-safa (delightful) to describe space early in his travelogue, ${ }^{3}$ begins to adopt a more diverse vocabulary. Farrokh-Khan gradually takes up a more complex discussion of functionality in space and begins to apply uncommon adjectives such as shirin (sweet) and zendeh (lively) to describe cities and streets. ${ }^{4}$ These cases show how the travelers gradually learned to fill out their narrative with a wider architectural vocabulary. 
The authors' weak expression of spatial qualities was coupled with their readers' similar troubles in visualizing their descriptions. In other words, not only were the travelers challenged in their search for pertinent signifiers, but they also knew that the signified objects and spaces were alien to their audience. Mirza Saleh shows his awareness that a shared experience is necessary to successful communication when he states, "Although no one will understand what I write or say unless they see it, I will try my best to explain." When attempting to discuss a flea circus, Rezaqoli basically abandons all hope that the reader (in his words, the "listener") will be capable of visualizing the peculiar phenomenon that he is about to explain:

Mentions of these events will cause nothing but disbelief in the mostame'in [listeners]. They may assume my dishonesty, when I talk about a small insect performing in such a manner, but I am not concerned with their trust, for I am writing this for my own gratification. ${ }^{6}$

In response to their paucity of architectural lexis, the authors approach the description of space in a variety of different ways. In some cases they simply give up on the attempt to describe things that they deem beyond the readers' experience, as when Rezaqoli announces, "[It] could not be conceived by human mind, but it must be seen in person." In many instances, the travelers simply use the original European signifier to refer to novel concepts. Examples of such transliterations in Abolhasan's memoir include "council," "square," "tower," "drawing room," "exhibition," "panorama," "opera," "park," and "bank." The latter three English terms are still commonly used in Iran today, more so than their Persian equivalents. Abolhasan also created a few remarkable hybrid concepts by wedding Persian and English words, presumably as a means to domesticate foreign realities. Examples include nuz-nevis (news-writer), nuz-khaneh (news-house), and dak-khaneh (dock-house). ${ }^{9} \mathrm{He}$ even practiced this playful juxtaposition of concepts in English, for example by suggesting to his hosts that the equestrian shows at Astley's Amphitheatre (see Plate 12) should be called "horse-opera" and that performances involving an indoor tank at Sadler's Wells should be named "water-opera." 10

Another strategy that the writers use involves the (de)construction of Persian words to stand in for novel concepts. For example, Mirza Saleh adopted the word rahahan (iron-path) to refer to railroads, ${ }^{11}$ and Rezaqoli coined negar khaneh (picture-house) to describe art galleries. ${ }^{12}$ FarrokhKhan used the term ruznameh, which at the time meant "personal diary," to refer to newspapers. ${ }^{13}$ Although these constructed words might not have been etymologically unprecedented, they were newly associated in these travelogues with ideas that were different from what the words had previously referred to. Interestingly, all the aforementioned examples found their way into Persian vocabulary and are used even today with the new meanings that these writers applied. The construction and redefinition of such 
terms, and their subsequent incorporation into the linguistic culture, not only shows the extent of the influence that travel writing had in shaping the Iranian experience of modernity, but also suggests the discursive nature of this phenomenon.

Finally, the writers often adopt the strategy of describing foreign experiences by comparing them to somewhat similar referents that would be familiar to Persian readers. Rezaqoli's memoir describes a peculiar pair of animals that he encountered while visiting a zoo:

The most wonderful animals of all, were a pair of creatures larger than an elephant, and higher than a camel; their necks are fourteen feet long, and their legs are handsome, their tails are like that of an Arab horse of red color, and with white spots on the face." ${ }^{14}$

This strategy, rather than capturing a cohesive picture of the animal, renders an exotic collage of familiar concepts. Fraser, who accompanied Rezaqoli and his brothers on this outing, states that "they were all struck with admiration at the giraffes, a creature which they had neither seen nor heard of before." 15

The same communication strategies are used when the travelers attempt to describe specific architectural elements that would be unfamiliar to their audience. When Farrokh-Khan, for example, tries to give his audience an idea about the sitting area in Paris's Champ de Mars, he compares it with the tekyeh, an often open space that serves as a venue for ashura religious mourning rituals in Iran. ${ }^{16}$ The vocabulary that Farrokh-Khan uses to describe buildings is frequently derived from an existing terminology of architecture that for centuries was used to signify specific Persian spaces. One building, to take another example, is described as "elevated from the ground with marble. Upon it there is a soffeh, and all around circulates a gholamgardesh, which consists of 70 or 80 marble columns." ${ }^{17}$ In the conventional meaning of these well-established concepts of space, the image that Farrokh-Khan's description generates is widely different from the actual space he had observed, which happens to be a Greek temple in the Acropolis.

In another instance, Farrokh-Khan says, "We passed through there and in the middle of the talar a me'jar of cast iron traversed around a square soffeh." 18 Farrokh-Khan's audiences, who had not seen the relevant European constructions, would have a rather indigenous imagination of the spaces thus described. (For an explanation of terms such as soffeh, me'jar, talar, and gholamgardesh, see the glossary at the end of this book). The descriptions that are presented in this way can be understood as something akin to describing a Buddhist temple to a medieval European audience with words such as "transept" and "nave."

Although this deformation of meaning is part of the standard limitations of language when grasping toward unfamiliar experiences, I would argue 
that the effects may be even more extensive for architectural terminology. Words such as gholamgardesh and talar have many conventionally accepted layers of meaning and connotation, which may even include their orientation, proportion, and construction technique. This complex layering of linguistic meaning in premodern architecture is often due to the fact that maps, such as plans, sections, and elevations, were seldom used in construction at the time. So the communication of ideas between the client, the master builder, and other parties involved in the construction process occurred almost exclusively through architectural vocabulary. In order to function as a clear pattern, in the sense that Christopher Alexander and colleagues have suggested, architectural vocabulary had to incorporate very precise and complex connotations. ${ }^{19}$ Thus, when the travel writers make use of these Persian terms, they are drawing on very specific indigenous concepts and images that are only marginally or imaginatively related to the European spaces being described.

Facing with the linguistic challenges of communicating novel spatial qualities to their audience, some of the travelers turn to different media to express their observations. Rezaqoli tells his readers that his brother Teymur made a drawing of a rhinoceros in the London zoo, in order to record its improbable appearance..$^{20}$ Unfortunately Teymur's sketches, which according to the brothers' companion James Baillie Fraser, who himself was a professional painter, were detailed and tastefully done, are not available today. ${ }^{21}$ While no drawing remains from the four individuals studied here, Naseraddin Shah's paintings from his trips to Europe are kept in good condition. Interestingly, these paintings, similar to the textual descriptions of safarnamehs, adopt a domestic style (language) to communicate foreign spatial experiences. Naseraddin Shah's watercolor drawing of a Farangi building has many stylistic similarities with Persian traditions of miniature painting, including bright colors, minimal shadows, and flattened spaces (see Plate 8). ${ }^{22}$ Like typical Persian miniatures, architectural elements in Naseraddin Shah's drawing are frontally depicted, with no perspectival vanishing points. This feature gives a two-dimensional quality to the painting, as if the front walls are depicted in an elevation format while the floor is simultaneously shown in a plan view (see the perfectly rectangular green areas on both sides of the fountain). ${ }^{23}$ Much like the descriptions in the safarnamehs, the foreign architecture of Europe finds a familiar language when mediated through the domestic lens of Persian miniature.

\section{Quantifying space}

The travel writers were determined to accurately report the signs of progress that they encountered in Europe. To overcome the absence of a vocabulary for describing qualities of space to an audience whom they suspected "could not believe any description of it," the writers attempted to enrich their records via quantitative data and measurement. ${ }^{24}$ This quantitative 
assessment often includes the length, height, weight, and age of buildings, as well as the cost and duration of their construction. Mirza Saleh, in particular, frequently adopts a scientific approach that incorporates complex measurement tools such as geographic coordinates and standardized units. ${ }^{25}$ In reference to Moscow's Kremlin, for example, Mirza Saleh says that the Tsar Bell is "the largest bell in the world. Its height is 6 zar' and 0.5 shahi, its periphery is $21 z a r$ ', and its thickness is three-quarters of a zar'. Their book claims that the bell weighs 72 thousand man-e Tabriz." 26

Whereas Mirza Saleh frequently relied on secondary sources for his measurements, most of the spatial quantities that Farrokh-Khan provides in his memoir were surveyed by his own crew. These quantities include counts of the number of columns, arcades, lamps, and steps in various edifices, as well as wall widths and spatial areas. Describing a visit to a ship along the banks of the River Thames, Farrokh-Khan's memoir (as written by his secretary, Hoseyn Sarabi) explains:

When we climbed over the ship, [Farrokh Khan] Aminolmolk asked Mirza Reza the translator to survey the ship's length and width. It was 314 steps long and 36 steps wide and its height was 30 meters, almost like a six-story castle." 27

Rezaqoli uses a mixed or intermediate approach to measurement. In some cases he provides information in non-Iranian units, which appears to have been collected from secondary sources. In other cases he provides his own counts and estimates. "For the sake of amusing ourselves," Rezaqoli says, "we sat at the window to gaze at those who passed by. We observed multitudes of people, and so many were the carriages which passed, that, according to our calculation, they were $3000 .{ }^{\prime 28}$

Interestingly, all of the travelers examined in this book - Mirza Saleh, Abolhasan, Rezaqoli, and Farrokh-Khan - frequently provide financial estimates in their journals. ${ }^{29}$ Abolhasan even inserted a large table of Britain's financial statistics in his memoir. ${ }^{30} \mathrm{~A}$ shared pattern among these financial reports is that at the beginning of each journal the emphasis is on measuring the profits made by institutions such as hotels, exhibitions, and theaters; whereas in later parts of the journals this emphasis shifts to a more balanced discussion that also includes costs. Although these financial inquiries and reports are likely related to the travelers' administrative backgrounds, they also seem to have developed as a product of the writers' sincere desire for a thorough sociological observation. This is particularly true in Mirza Saleh's case, for example when he describes St. Paul's Cathedral (see Plates 3 and 9):

It seems that its length from inside is 183 zar', its width is 84 zar', its height is 112 zar', and its periphery is 800 zar'. The whole cathedral is built of white stone. It has cost 750 thousand tomans. If they decide to build a similar building today it would cost five times more, because 
today a laborer's daily wage is a quarter toman but before, they paid 10 workers together a quarter toman. ${ }^{31}$

The travelers' attitudes in providing financial evaluations of material progress in Farangestan confirm their intention to bring back more than just reports of foreign activities or an abstract theory of progress. Their investigations into practical finance indicate a strong interest in applying these same forms of development in Iran. However, while the travelers' precise interests and quantitative approaches may seem to lead toward a desire for direct reconstruction (especially when viewed by non-architect readers), what tends to get lost in these quantitative translations of space is the overall image. Paradoxically, this quantification of space approach conveys a feeling of precision while remaining unable to produce accurate formal imagery. While adopting Persian approximations as referents encourages the readers to project their own preconceptions onto descriptions of Europe, the measurements solidify the domesticized imagery with a quantitative authority.

\section{Journey from the center of the earth}

The Persian concepts of Farang(estan) and Farangi, similar to linguistic cognates such as farày in Thai, ferenggi in Malay, barang in Cambodian, and alafranga in Turkish, etymologically refer to France and the French. ${ }^{32}$ In the earliest references, dating from thirteenth-century Persian literature, the term connotes an "inferior" and hostile image of the often European Other. However, since the late eighteenth and early nineteenth centuries (the time of the travel writers discussed in this book), Farangestan and Farangi had evolved into an "advanced" and civilized conception of "the West" and "Westerners." Conceptually, what has remained similar in the evolution of these concepts is their function as general signifiers for an all-encompassing image of the foreign Other, which disregarded the cultural, historical, and social differences among various kinds of Farangi. The frequent application of the terms Farangi and Farangestan in the travel accounts cannot be discussed without considering the politicized objectification that resulted from this socially constructed polarities.

This socially constructed division between Iran, at the center of the earth, and Farangestan, as a distant Otherland, is well-documented in Fraser's introductory lines in his book about the princes' journey to England. Fraser, who had close interactions with many Persian travelers, including Mirza Saleh, Abolhasan, and Rezaqoli, suggests,

[Farangestan] is a world as distant almost, and as difficult of access, in the imagination of a Persian, as the moon might appear to us. . . The utter discrepancy between the manners and customs of Europe and those of the east, have tended strongly to allay the warmth of curiosity which has been excited by their narrative of its wonders ... [and] 
to widen the terrible gulf that in their imagination divides Persia from Europe. ${ }^{33}$

To better understand the imagery associated with the concept of Farangestan, I would like to introduce another term: shahr-e Farang (literally, "city of Farang"). This "city" was an implementation of the eighteenth-century peep show. ${ }^{34}$ It basically consisted of a stereoscope mounted onto a large brass-bound box, which allowed the scene contained within to appear threedimensional to the viewer. Shahr-e Farang was slightly redesigned from the European peep show so that the viewing port sat in front of the box instead of on top. It also allowed multiple viewers to see the show simultaneously. The author and director Farrokh Ghaffary, who coincidentally happens to be Farrokh-Khan's grandson, has written about shahr-e Farang, explaining that it had three viewing ports with thick lenses that projected stereoscopic images. ${ }^{35}$ Notably, the scenes that could be viewed in the shabr-e Farang amalgamated a variety of heterogeneous locations, ranging from Mecca to St. Petersburg, into a single unified landscape. Much like this vision of shahr-e Farang, the overall concept of Farangestan in the Persian mind consisted of a collage-like imagery that merged together a wide array of cultural and geographic territories.

The term Farangestan is used very frequently in the traveler's diaries. The invocation of this concept takes on a sort of utopian dimension that while distancing itself from the status quo in Iran, it still adheres to values, desires, and symbolism that is rooted within Persian/Islamic cultures. Farangestanboth when standing in dialectical opposition to the Iranian self and when projecting domestic ideals on foreign objects and spaces - is not an entirely new discovery but rather an embodiment of familiar myths and archetypes. Abolhasan, for example, frequently compares his observations in England with visions of more local wonders, such as al-Aqsa Mosque, Mount Damavand, Shatt al-Arab, Taq Kasra, the Jungles of Gilan, and Mount Behistun. ${ }^{36}$ Discussing Abolhasan, the later commentator Naghmeh Sohrabi explained that for him, "wonder acts not as a marker of never-before-seen sights but almost the opposite: a natural beauty [or a built environment] comparable to what he (and presumably his readers) had seen before." ${ }^{37}$ Because each traveler carried with him such visions and preconceptions, his voyage was not simply a journey into unknown geographic regions, but was rather a "transition from the imaginary to the real." ${ }^{38}$ The travelers arrived in Farangestan hoping to rediscover the originals of the stories that had long been the subject of their fantasies.

To look at a more concrete example, Rezaqoli, when he first sees a balloon, states, "I had heard about this technology in Iran and I was eager to see it." ${ }^{39}$ Prior to his trip Rezaqoli made a committed effort and dedicated several pages in his journal to recording "instructions about Farangestan" as he learned them from the British Consul in Damascus. ${ }^{40}$ At this point Rezaqoli discusses Farangestan almost as if it was a specific geographic region, with 
clear borders, one King, a singular history, its own unique shari'a (religious law), and cohesive customs, artistry, and costume. ${ }^{41}$ When the British Consul in Beirut asks where he intends to go, Rezaqoli's response is simply, "to Farangestan." ${ }^{42}$ As his journey progresses, however, Rezaqoli gradually becomes familiar with the diversity of Europe and its many countries, and this simplistic image of Farangestan becomes more complicated. He begins to evince a recognition of Farangestan's various nations, languages, laws, and climates. ${ }^{43}$

Farrokh-Khan's memoir contains an interesting dichotomy in the author's perception of Istanbul, which he visited both at the beginning and at the end of his journey. On his way to Europe, when Farrokh-Khan first arrives in Istanbul, he incorporates it into his unitary mental map of Farangestan: “From Iran's embassy to Sultan's Palace [Dolmabahçe], which is called the building of Beşiktaş, is about an hour. All the streets were well maintained and on both sides were Farangi stores and houses." 44 In contrast, on his way back to Iran after having visited many European nations, Farrokh-Khan downgrades Istanbul and the Ottoman Empire in his mental hierarchy of progress, and situates this region outside of the amorphous borders of Farangestan. In this stage of his journey, Farrokh-Khan constantly points out the backwardness of the Ottomans, with a critical attitude that is quite rare in his memoir. This negativity rises to its extreme during his return passage through the Dardanelles, where he describes,

an extremely filthy city; the streets were all rocky and full of dirt . . . these signs that I observed show that the Ottoman nation is facing decay every day. This decadence is because of nothing except ignorance. It will not take long until they will be totally finished. ${ }^{45}$

Farrokh-Khan's re-evaluation of Farangestan indicates its flexible and deterritorialized mental borders that could be discursively adjusted to incorporate new observations.

Toward the end of his trip Farrokh-Khan considers himself a person who has arrived at a thorough knowledge of Farangestan. In narrating his conversations with Abdülmecid, the Sultan of the Ottoman Empire (r. 1839-1861), as well as with the Ottoman prime minister, he signals his self-assessment by indicating that both of these prominent individuals now recognize him an expert on the topic. Through the voice of these characters, Farrokh-Khan addresses himself as someone "who has visited all of Farangestan" and "knows all about Farangestan." ${ }^{46}$ However, even from the very first day of his arrival in Europe, Farrokh-Khan seems to already know all about Farangestan. For example, he believes from the beginning that there is one unitary theme behind all Farangi buildings, and that he knows what this theme is. Given the pre-elaborated imagination of Farangestan's technology, culture, customs, laws, shari'a, and lifestyle in the minds of the travelers, it is perhaps unsurprising for them to also clearly identify a "Farangi style 
of building. ${ }^{47}$ On Farrokh-Khan's very first stop in Europe, he announces that,

Athens is designed on the layout of the cities in Farangestan. Its streets are straight and paved with stone. ... Outside the city on a vast field, the king has built a palace based on the Farangestan design. On one side, there is a special garden and on the front a spacious square." ${ }^{8}$

This imagination of "Farangestan design" imposed its simplistic and unifying outlook onto the vast complexity of architectural styles that the travelers observed in Europe. While the unprecedentedly diverse architectural styles practiced in nineteenth-century Europe, ranging from revivals of various historical styles to industrially influenced structures, were largely irrelevant to these travelers, they were able to recognize the ancient structures remaining from the past apart from the more contemporary ones. This differentiation between the old and the new served as a platform to relocate Farangestan as a temporal destination for the self. The travelers' shared approach in emphasizing how uncivilized Europe used to be was in part an attempt to render a bright future for Iran, a country that to them was experiencing a similar temporary backwardness. ${ }^{49}$ To maintain the refined image of Farangestan as a temporal destination for the self, Europe's past was associated with the contemporary conditions of Iran. Farrokh-Khan's description of the ruins of Pompeii is a clear architectural example, where "the layout of the buildings is like in Iran ... not at all does it resemble the Farangestan design." 50

Farangestan, then, derives its meaning not from particular geographical referents, but as an imagined view of progress and an alternative to the Persian self. The same architectural image of Farangestan buildings can be detected in Abolhasan's memoir. In fact, Abolhasan's early references to Farangi characteristics consist almost entirely of descriptions of architecture and urban form; similar to Farrokh-Khan's observations, Abolhasan's references entail height and materiality. Describing the city of Izmir, for example, he says that, "following Farangestan's building pattern, the houses were five stories and made out of stone." ${ }^{51}$ It is only after traveling more extensively in Europe that Abolhasan begins to mention Farangi habits, laws, religions, and customs and all of these references show a gradual transition from the singular to the plural. $^{52}$ Abolhasan eventually even introduces Farang itself in a plural form (Farangan; more than one kind of Farangi), to express his growing understanding of the diversity of Europe. In one passage he mentions a gathering of Farangan ambassadors (safiran-e Farangan), and in another he describes the multiplicity of Farangan religions (mazaheb-e digar Farangan)..$^{53}$

The unitary Farangestan style that informs the original imagination of these authors (and, presumably, their readers) is not only attributed to the broader aspects of architecture and urbanism, but also to furniture and ornamentation. When Farrokh-Khan's secretary writes about visiting Russia, he 
talks about a lady who invites the emissary to her house: "It was a house in the middle of a huge garden, built in the style of Farangestan houses and gardens. And, whatever you may find in the houses of the Farangi nobility was available in her house." ${ }^{54}$ These descriptions indicate that the author, as well as the intended reader, already has a very firm idea of the style of noble Farangi houses and what may be found in them.

To the travelers, Farangi architecture is envisioned primarily as the alternative to the existing condition of Iran's architecture, which they understand as buildings that are single-story, follow a central courtyard pattern, have a reflecting pool in the middle, and are based on a strict division between public and private spaces. The important factor that I want to emphasize here is how the journey to Farangestan acts as a mental journey, between the existing self and a preconceived ideal Other, which is typically envisioned as a possible future self. A quotation from Farrokh-Khan reveals the utopian aspect of this vision. Describing Naples as "the best among Farangestan cities," he glorifies its relevant attributes:

Its good weather, the quality of its location, and the beauty of the city. Besides the sea, the city lies along a length of three miles and its width reaches up the hill. Perfect buildings, on top of one another, reach to the peak of the hill. All houses have a courtyard and in the middle of winter all kinds of flowers are glowing and all trees are green and fresh; hanging from them are fresh oranges, lemons, and tangerines. ... A big city, a fine port, and perfect buildings, four to five stories, with wide and straight streets paved with stone, neat and clean. ${ }^{55}$

The first question that comes to mind is, since Naples is one of the first cities in Europe that the author visited, how can he already know that it is "the best among Farangestan cities?" Perhaps one explanation could be that Farrokh-Khan added this assessment to his memoir sometime after his tour was over. More likely, however, in relation to his overall narrative, is that the author already had a clear understanding of Farangestan in mind before his arrival. In this understanding, Farrokh-Khan was not comparing Naples to other actual locations, but was rather envisioning it through the lens of a projected utopian imaginary. We do know that Farrokh-Khan's secretary, who was responsible for actually writing the memoir, had previous visited Russia, so it is conceivable that this experience affected the superlative evaluation. In either case, however, the vision of Naples described here conforms to an essentializing vision of Farangestan that spreads beyond any specific geographic boundary and is more splendid than any objective reality. Farrokh-Khan's description of the nearby city of Messina, interestingly, opens with almost exactly the same words and phrases that he uses to describe Naples, including four- to five-story buildings; streets that are straight, paved, and clean; houses with courtyards; and orange, lemon, and tangerine trees. ${ }^{56}$ 
Mirza Saleh, who is more analytically inclined than the other travelers, is very attentive to recording the names and details of every town he visits, no matter how small. This attention to detail, however, does not prevent him from using the nonspecific concept of Farangestan. From the earliest parts of his journey he appears to struggle with the application of this ideal. His first destination is Russia, where he notes with some surprise the presence of arched ceilings. It appears that he was not expecting such designs, based on his assumptions about the flat-roofed Farangi style. ${ }^{57}$ For this and other reasons, Mirza Saleh begins to separate Russia from his vision of Farangestan. In one notable passage he discusses trade between Russia and Farangestan, apparently using the latter term to refer to Europe.$^{58} \mathrm{He}$ describes the architectural style of buildings in Tbilisi and Mozdok to be "Russian," 59 and in other locations (such as in Nakhchivan) when he notices buildings with a "Farangi" style, he perceives them to be exceptions. ${ }^{60}$

Even when Mirza Saleh visits St. Petersburg, which he describe as the best city he has seen so far on his trip, he still hesitates to include it as part of Farangestan: "What led Peter the Great to build this city was the fact that no other city in Russia had access to the Baltic Sea in order to provide maritime trade with Farangestan." ${ }^{61}$ On at least ten other occasions Mirza Saleh makes it clear that he does not include St. Petersburg as a Farangi city. ${ }^{62}$ Nevertheless, there are some passages where he expresses more ambivalence:

Because Peter the Great had seen other Farangestan cities, he designed the whole city [of St. Petersburg] in one stage, based on his taste, and on that of Farangestan's architects, and what he had observed. Mr. William of England, Abolhasan Mirza, and most other people say that St. Petersburg is the best of the Farangestan cities. $^{63}$

This ambivalence is in some passages extended to Russia as a whole, for example when Mirza Saleh describes Russia as "one of the biggest countries in the world and actually the strongest among all other countries in Farangestan. Some of its regions are part of Farangestan; they call it European." 64

As the cited passage indicates, Mirza Saleh's experiences in Russia encourage him to identify Farangestan more specifically with Europe. Interestingly, when Mirza Saleh then leaves St. Petersburg and travels towards England, his references to Farangestan stop almost entirely. It seems that, being unable to reconcile the vision of Farangestan with the complexity he encountered, Mirza Saleh simply abandoned the concept altogether in the later portions of his memoir, and replaced it with more specific terminology. ${ }^{65}$

Examining how the dynamic borders of Farangestan are transformed in these writings notably reveals the role of intervening seas and maritime travel in constructing the perception of the foreign Other. Beirut, St. Petersburg, and Istanbul, respectively in Rezaqoli's, Mirza Saleh's, and Farrokh-Khan's 
descriptions, at first contain many of the elements of wondrous progress that the travelers expected from Farangestan. After sailing away from these cities, however, the travelers modify their image of Farangestan, repositioning it to lie on yet-more-foreign shores, while the abovementioned locations are relegated to lesser status. Bodies of water can thus serve as mental borders and states of transition (see Plates 2, 5, 6, and 7). They not only define geographic regions but also constitute mental territories. In other words, sea becomes a medium between the realm of the self and the unfamiliar overseas. While land travelers see changes gradually as they approach their destination, maritime transport allows for a sudden experience of surprise and astonishment.

\section{Farangestan as a wonderland}

At the city gate [of Damascus], we saw something like a gigantic elephant riding a horse. Well, not much was visible from the bulk of the poor horse, except for his two ears. When it came closer, we realized that it was a human being with such a physique. Subhanallab! His huge belly had covered the horse's neck and his hips were over its thigh. I asked the British Consul, [John William Farren], with astonishment, "have you ever seen such a person before?" "I have journeyed all of the seven Farangestan," he replied, "where all kinds of men exist, but never have I set eyes upon a person with such a figure." 66

Those who write about journeys tend to see them as a deviation from the routine. In travel writing, as can be seen from the quotation from Rezaqoli's diary, often authors abandon descriptions of the regular in favor of the unexpected and the bizarre. Several of the travelers examined here, when recording their daily accounts, kept some entries empty except to say, "nothing interesting happened." ${ }^{67}$ This attitude suggests that the travelers saw no point in reporting events that lacked an unfamiliar nature. Naturally, most Persian travelers of this period tried to entertain their readers with stories about the strangeness and peculiarities of Europe. The art of storytelling also doubtlessly motivated them to exaggerate differences and accentuate oddities. The Europe that they represent in the memoirs is a wonderland: a fairy-tale world full of marvelous scenes, unusual objects, weird gadgets, and strange habits.

Travel writing can thus serve as a collection of personal anecdotes that illustrate the author's exclusive access to the foreign wonderland. It is no wonder that Abolhasan calls his diary Heyratnameh - the Book of Wonders. "Since I witnessed and recorded many wonders and oddities," he says, "naturally, same' in [literally, listeners] and readers of these words were greatly shocked; therefore, I shall call this journal Heyrat-nameh." ${ }^{68}$ In fact, Abolhasan admits to deliberately provoking the readers' heyrat (astonishment) as a means for raising their attention toward his didactic aims ${ }^{69}$ Instances of wonderment are so frequent in Abolhasan's portrayal of Farangestan that 
the words suggesting astonishment are repeated more than seventy times in his memoir.

Rezaqoli likewise had a particular tendency to fill out the image of Farangestan with oddities and peculiarities. In all of Farangestan, he points out, "they don't have yogurt, nor do they have a bathroom." 70 When making this comment, the only European country that Rezaqoli had visited was Malta (which he considers "a village compared to Farangestan cities"). ${ }^{71}$ As his journey continues, Rezaqoli's memoir comes to brim with stories of Farangestan's oddities, including a creature with a long tongue that eats ants, a tortoise larger than a cow, a person selling corpses and mummies to tourists, a gigantic ship that resembled a floating city, shipwrecked sailors who had to eat two of their mates to survive, a strange animal brought from South Africa, a mental patient who had been screaming day and night for seventeen years, a balloon crash, a dog that embarrasses its owner at a party by exposing his dirty underwear, dogs shopping for their owners with baskets that contain money, and a dog as big as a cow. ${ }^{72}$

Such stories allude to a mysterious and exotic rendering of Farangestan as a place of wonder and fantasy, rather than an accurate depiction of the travelers' experience. For example, Fraser observes that Rezaqoli, on his way back from a tour of St. Paul's Cathedral, showed quite a bit of excitement at seeing wax busts in a hairdresser's window: "I do think he was more tickled by these same wax dolls than by all he saw at St. Paul's."73 However, while the wax busts may have created a sense of surprise and interest, they do not fit well into the expectation of Farangestan's wondrous splendor, and therefore it is not surprising to find that these items are not mentioned at all in Rezaqoli memoir. Instead, the memoir, taking part in building upon the constructed image of Farangestan, dwells on a lengthy description of the cathedral and its marvelous aspects (see Plates 3 and 9). ${ }^{74}$ In a similar case, where Fraser reports the prince's complaints about a dull visit to a zoo, Rezaqoli's diary portrays the event as a joyful tour and dedicates several pages to a detailed description of its wonders. ${ }^{75}$

There may be several possible explanations for the travelers' "unpredictable" reactions to the wonders of Europe. One important aspect is that the mystery of Farangestan did not originate merely from what the travelers found subjectively wondrous, but rather from what they culturally deemed as deviating from their expectations and norms. The travel writers' assessment of what might be striking to their readers was undoubtedly different from cultural expectations shared by today's readers, as well as those of the travel writers' European companions. James Morier, the British diplomat and author who traveled with Abolhasan, ridiculed the traveler's indifference to the "increasing interest of the road" on his first approach of London - an outlook that Sohrabi has attributed to Morier's immersion in the European "dictatorship of spectacle." 76 The Persian travelers, it seems, simply had a different perspective on what sights and wonders were worthy of note. 
At the same time, there are other instances that indicate the travelers may have intentionally adopted blasé gestures to hide their true astonishment from their European peers. Morier observes that, "the first night he [Abolhasan] went to the opera, the impression of surprise, which he received on entering his box, was evidently very strong, although his pride made him conceal it." "77 Elsewhere, Morier mentions how Abolhasan "did not seem at all astonished" at a ball in Istanbul, while his attendants "eyed every thing with the most anxious astonishment and attention ... they sat with their mouths wide open, and eyes full-staring, and uttered not a single word."78 In these cases, while the European companions were exposed to the travelers' studied indifference, their Persian readers enjoyed a much exaggerated version of the same events as recounted in their diaries.

In their journals, the travelers seldom try to demystify Farangestan, but rather spice up their experiences with the taste of wonder and curiosity, actively enriching the magical qualities associated with the foreign Other. As Sohrabi argues, in some cases this wonder seems to be less an authentic indication of astonishment than an intentional literary device. ${ }^{79}$ Abolhasan, for example, describes Gibraltar as "a mountain that dwarfs Mount Alborz, Mount Damavand, and Mount Alvand in height"; in reality, however, the Rock of Gibraltar is more than thirteen times smaller than Damavand. ${ }^{80}$ An even more revealing example can be seen when Rezaqoli describes his first experience of riding an elevator. In his journal, the prince portrays the elevator as a wondrous room with seats, which flew like a bird in the sky for fifteen minutes until it landed on a different floor ${ }^{81}$ In contrast, Fraser, who accompanied the princes during this event, informs us that the brothers were not quite as taken by fancy as Rezaqoli's journal might suggest: "They preferred ascending by steam in the cylinder, to mounting the staircase on foot. The movement astonished them a good deal; but it was not altogether a grateful sense of wonder." ${ }^{82}$ In the same building, when Rezaqoli describes his first encounter with a panorama, he mystifies the experience by pretending that he and his brothers could not "distinguish the real from the artificial:"

I said to Mr. Fraser that, although this is a very excellent view of London and of the country, yet I should like more to see and visit some of the English arts, and asked him to take us to such places, because what we see here, we see every day. Mr. Fraser laughed at our question, and said, "Is any art better than what you are actually now seeing?" "What an art is it!" we said. "does any one doubt the power of the Creator, by whose order this world was created with its natural beauty?" Then Mr. Fraser said, "This heaven that you see is not more than four yards distant from you; if you throw an orange against it, it will return back to you." I was angry with him at his saying this; it seemed as if he were playing with us. I said, "O man, have we not eyes to distinguish between the real and artificial?" Mr. Fraser replied, "It would be impossible for you to know 
how this is done, unless you saw it." ... This increased our disbelief; however, we went up and down until we were satisfied. ${ }^{83}$

Fraser's account of this story is very different from Rezaqoli's narration. According to him, the brothers were not confused by the art at all. They "examined every part of the picture ... [and] appeared quite to understand that it was a painting upon a sheet." ${ }^{84}$ They even commented on the painting's details and noted the cracks in the plaster.

As part of their investment in recounting the wonders of Farangestan, the travelers were particularly eager to report on places and objects that hold some kind of record. The abundance of superlative adjectives in Mirza Saleh's account, for example, include England's tallest church spire at Salisbury Cathedral (see Plate 10), England's largest organ at Exeter Cathedral, England's biggest naval hospital at Plymouth (Devonport), and the world's largest dockyard at Bristol, among many others. ${ }^{85}$ While this fascination with superlatives is by no means exclusive to the group of travelers that I discuss here, it does indicate how the image of Farangestan in their narratives is connected to the idea of magnificence.

Many of the Farangi wonders introduced in the travelogues, like the examples from Mirza Saleh mentioned earlier, have an architectural dimension. England to Abolhasan is "a country full of wonders: her Government of ministers, generals and admirals, her architecture and inventions amaze event the wisest of men." ${ }^{86}$ The same three types of wonderments - sociopolitical, spatial, and technological- comprise the majority of examples that Abolhasan presents in his Heyratnameh. While Abolhasan makes note of sociopolitical wonders such as women's involvement in society, the high regard for individual rights, and the sovereignty of the constitution ${ }^{87}$ he reserves a greater attention for architectural marvels, including the height of buildings, carvings on an obelisk, the incredibly large beams of a ship factory, city lights, residential lights, the frescos on a portico, multistory stone constructions in Bath, and the enormous area of St. Paul's Cathedral, ${ }^{88}$ each of which I shall discuss separately in the following chapter.

\section{Virtual realities}

Confusion between the real and the virtual is a recurring theme in the travelers' memoirs. Pretending to visit the King of England's palace, Rezaqoli's brothers took him to a wax museum instead, where he reportedly mistook a statue for the King. ${ }^{89}$ Similarly, Abolhasan mentions that a stone statue of England's foreign minister was so realistic that he could not tell the difference between it and the real person. ${ }^{90}$ Later in his travels, while describing the landscape of Vauxhall Gardens, Abolhasan admits that, "I truly do not know if it was real or an illusion" (see Figure 3.1). ${ }^{91}$

As noted in the previous section, some of this confusion between reality and illusion was likely an intentional affectation, one that is tied to the 


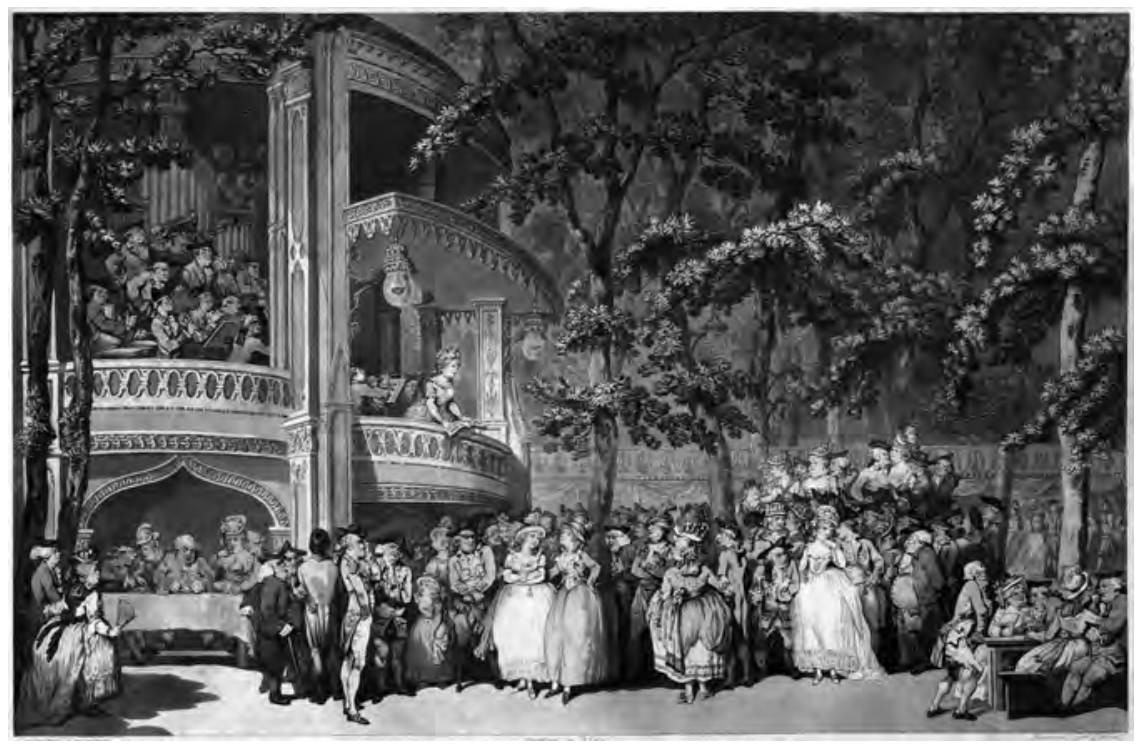

Figure 3.1 Vauxhall Gardens was a great source of wonder to the traveler, as they enthusiastically describe its symmetrical paths, lighting features, and public mingling of men and women.

Source: The Elisha Whittelsey Collection, The Elisha Whittelsey Fund, 1959, The Metropolitan Museum of Art.

representation of the wondrous nature of Farangestan. At the same time, however, the new artistic media that the travelers encountered, such as panoramas, dioramas, photography, and early cinematic devices, doubtlessly reinforced for them the illusionary nature of representation, which in some instances seems to have truly overwhelmed the travelers. Farrokh-Khan discusses how "it was impossible to tell the real thing from its image" in a theater, and asserts that the experience "was mind-boggling and eye-popping." similarly expresses his astonishment about how indistinguishable "real and artificial" had become after he visited a panorama. ${ }^{93}$ Referring to the "artificial realities" of the panorama as a "miracle" and the show that he witnessed in a diorama as "magic" and "trickery," Rezaqoli states "no one is able to identify whether these are representations or reality." As Fraser also suggests, Rezaqoli was probably authentically amazed by the optical illusions, lighting tricks, and mysterious appearance and disappearance of the congregation of people in the diorama show; he reports the prince as saying in this instance: "This is the finest and most wonderful [show] you have taken me to. Afereen! Afereen! This cannot be a picture; it must be reality!" 94

How authentic the travelers' claims were about confusion between reality and illusion is irrelevant here. What matters most is their frequent encounter with such virtualities and the way it affected their perception of Farangi progress. Another interesting example that shows a magical perception of 


\section{2}

modern technology is Farrokh-Khan's description of riding in a train: "The train moved so rapidly that nothing could sustain from the future and the present; everything was in the past tense." 95 This miraculous movement in space, as framed by the window of Farrokh-Khan's train car, seems to catapult the traveler into a visionary state where the present was left behind. It generated an illusionary image of Farangestan's progress that transcends time itself.

When it comes to architecture, a similar pattern of confusion between virtuality and reality can be discerned in the travelers' memoirs. Some of this confusion was an attribute of the architecture itself. Mirza Saleh's detailoriented observations allowed him to identify how a stone appearance was faked in St. Petersburg. The walls of the houses, he explains, "are made of brick with a stucco plaster on top of it, which is formed like stone, and so foreigners will assume the whole wall is built out of stone." ${ }^{96}$ Abolhasan was likewise impressed by the trompe l'oenil effect created by the painting of statues on the ceiling cornice at Buckingham House. ${ }^{97}$ The stage-like quality of many architectural and urban elements in Europe not only encouraged a theatrical perception of space in the travelers' minds, but also, particularly for those travelers who did not share Mirza Saleh's inquisitiveness, alluded to miraculous and magical properties. Turns of expression describing a room that flies like a bird, a glass house that can go deep under the sea, walls and ceilings that move in all directions, floating cities, domes that fly in the sky, and gardens with four-season fruits emerge not only because Rezaqoli lacks the vocabulary for an elevator, a diving bell, an observatory, a large ship, a balloon, or a horticultural garden, ${ }^{98}$ but also because the author has slipped into a fanciful vision of architecture that transcends reality. In a similar fashion, Abolhasan describes the gigantic gates of private water-canals on the Thames that open with the twist of a screw, ${ }^{99}$ and also the wondrous acoustics of St. Paul's Cathedral:

I was standing with Sir Gore Ouseley and his brother, Sir William Ouseley, when a small door in the gallery was slammed shut: the sound echoed through the dome like cannon-fire. Then Sir William Ouseley went to the far side of the gallery; with his face to the wall, he whispered in English: "you speak English very well." I heard the words perfectly. ${ }^{100}$

The theatrical, magical, surreal, and high-tech imagination of European architecture drove the travelers to gradually abandon an in-depth search for construction details in favor of virtual representations that conformed to a utopian idea of Farangestan. This explains how Rezaqoli can move effortlessly between descriptions of magic tricks and practical technology:

We were also shown here a figure of a negro man made of iron, so ingeniously, that it could not be distinguished from a living man; two swords were made to appear to cut at his neck, through and through, 
and yet his head never falls. Also carriages and coaches made of iron, which go by themselves on roads of iron. ${ }^{101}$

\section{Representing the representation}

In the act of representing Farangestan through their writing, the travelers seem to understand that representation is tied to power. Farrokh-Khan and Rezaqoli express satisfaction in presenting their observations to Ottoman officials, and they revel in their status as Farangestan experts. ${ }^{102}$ Abolhasan, as discussed in chapter two, displays his writing as a tool to maintain his image as a knowledgeable person. Similarly, the didactic nature of Mirza Saleh's book positions him as the authoritative source of knowledge about Farangestan. The act of representing the Other through writing thus allowed the travelers to gain a kind of mastery over their material - and while they enjoyed the power associated with authorship, writing provided them with a means to resist the hegemonic ways in which their own culture and personhood was represented by Europeans.

Throughout their trips, the travelers were exposed to many objects of curiosity, which were themselves representations of other objects, such as art galleries, exhibitions, museums, panoramas, theaters, zoological gardens, botanical gardens, circuses, operas, and photo galleries. All these modes of representation can be understood as participating in hegemonic desire, a passion to control body, mind, history, and nature. Among the various representations that they encountered in Farangestan, one was particularly close to the travelers' identity: European representations of Iran. FarrokhKhan notes three occasions where views of Iran were exhibited: a theater in which cardboard models of Iranian women were milking sheep, a booth dedicated to Persian crafts in the Great Exhibition at the Crystal Palace (see Figure 3.2), and finally, in Schönbrunn Palace in Vienna, a room supposedly designed and decorated in an Iranian fashion. ${ }^{103}$ Abolhasan mentions an opera in which an actor plays a Persian prince, a panorama showcasing Persian cities, and a man supposedly dressed as a Persian at a masquerade ball. ${ }^{104}$ Needless to say, such representations were quite often far from an honest, let alone accurate, depiction of Iran. Abolhasan, for example, complains that the supposedly Persian dance he witnessed at the opera "had absolutely no resemblance," and that the supposedly Iranian clothing at the masquerade ball "looked nothing at all like those we wear."105

In addition to these inaccurate views of Persian culture, the travelers learned that they themselves were also an exhibit for the Farangi's gaze. Abolhasan was quite a spectacle in England; he was extremely popular with the British press, as well as in American newspapers. As the British writer Charles Lamb suggested, he was at the time "the principal thing talked of." ${ }^{106}$ On multiple occasions the papers reported that Abolhasan attracted a great deal of public interest; the Morning Post noted that his appearance led to "great numbers of persons assembling from curiosity alone," and in 


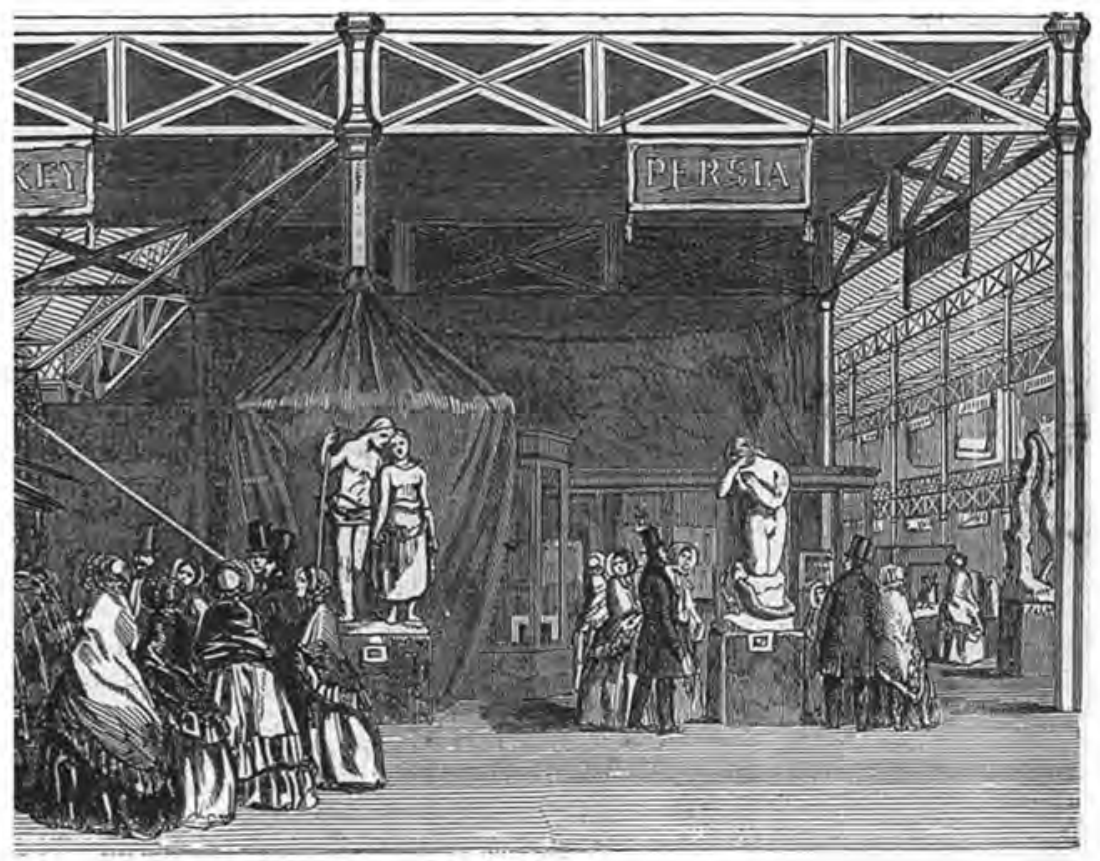

Figure 3.2 Iran's booth at the 1851 Great Exhibition in the Crystal Palace.

Source: Grand panorama of the Great Exhibition of all nations 1851 from The Illustrated London News. Image scan and text by Philip V. Allingham, victorianweb.org/history/1851/32.html.

another context the same publication described how the size of a gathered crowd prevented Abolhasan's footmen from being able to open his carriage door. ${ }^{107}$ In his journal, Abolhasan also writes of how the "citizens of London ... gathered in large numbers to see us pass" and that "many children gathered around me." 108

Early in his trip, at Gibraltar, Abolhasan asks about the reason for such enormous crowds gathering around him. In response he is told, "It is because this location is the meeting point of ships, merchant vessels, and battleships, and because no one from Persia has ever visited this land." 109 Soon after arriving in England, however, he comes to a better understanding of this phenomenon: "The port [Plymouth] has about twelve thousand households," he writes, "at least two thousand of which were constantly in front of our place. They had come to see the beard and outfits of Iranian people." 110 Upon his first visit to an opera, Abolhasan described a parallel between the gaze that he felt and the experience of an actor on stage, writing that, "when the curtains fell, people started whispering because my bulk appeared strange to the English people; they considered it taghlid-e no [a new show]." 111 
Fraser indicates that one of Rezaqoli's brothers, Vali, came to the exact same conclusion. He quotes Vali as saying that, "Wherever I sit they will be sure to come fast enough. I am as great tamashah (raree-show) [spectacle] myself, as anything here." ${ }^{112}$ Rezaqoli reports in his memoir that approximately fifty thousand people gathered to see the princes in Gibraltar, as well as ten thousand in Bath, thirty thousand in Enghien, twenty thousand in Liège, and thirty thousand in Vilshofen. ${ }^{113}$ Although these numbers may be exaggerated, both Fraser and the princes' translator, Kayat, confirm that great crowds gathered to see them. Writing about his attempt to visit Liège with the princes, Fraser confesses that he had never seen so many people in one place, and notes that the sight of their foreign costumes drew such a crowd that they were forced to turn back and give up on their attempt to see the city. ${ }^{114}$ Likewise, Kayat describes how the house where the brothers were staying became "full of people anxious to see the Princes, their swords, their caps, their slippers, their pipes, their horses' saddles, and their cook." 115 It is not an exaggeration, then, to say that the frenzied gaze of the Farangi led the travelers to feel like objects displayed in an exhibition.

Similar to Lacan's idea of the formation of self-consciousness during the "mirror stage," 116 the uncanny experience of being an object of others' gaze made the travelers hyper-conscious of their external existence. They understood how their appearance, clothing, customs, language, and history were constantly the subject of observation, analysis, and judgment. The European gaze served as a looking glass, albeit a warped one, through which the travelers saw reflections of their identity, which was now extended by the European spectatorship to confirm a broader preconceived image of an oriental culture. The travelers soon adjusted to this role of being representations of their nation, religion, and culture. Abolhasan, for example, writes about feeling ashamed upon learning that another Iranian had stolen the furniture provided for his residence by the East India Company, saying that incident is "an embarrassment to all Iranian people," a reflection that he now felt on his own shoulders. ${ }^{117}$

Perceiving their selfhood through European spectatorship, the travelers became more highly aware of their national identity, and its contrast to Farangestan. ${ }^{118}$ The constructed duality of self/Other grew more distinct, which further solidified the Otherness of the Farangi. This duality, which seemed abstract at home, became ever more real in the foreign context and imposed concrete consequences, such as the travelers being required to pay higher prices for goods and services in comparison with the locals. ${ }^{119}$ Some aspects of being a spectacle could be beneficial for the travelers, as Sohrabi explains when he argues that Abolhasan intentionally sought out the gaze of the multitudes: "It was precisely through his being a spectacle that the power of his mission could be played out, and it was by narrating that spectacle back home that it could be justified." ${ }^{20}$ However, while the travelers might occasionally have relished being the center of attention, they understandably detested being treated as an exhibit. Abolhasan expresses 
annoyance in his writings at having to "escape from the spectators," as well as frustrations about the way that his appearance distracted younger women and times when the crowds prevented him from engaging in activities that he enjoyed. ${ }^{121}$ Farrokh-Khan, "whose oriental aspect and picturesque appointment," according to European commentators, "made [him an object] of peculiar interest," 122 writes in a self-promoting fashion about the large crowds that gathered around him, describing them as a "cheering entourage." ${ }^{123}$ Nonetheless, as his tour continued, Farrokh-Khan describes how he began to dress in "Farangi outfits" in order to avoid some of this attention. ${ }^{124}$

Mirza Saleh likewise complains about being constantly stared at by women, chased by children, and laughed at by crowds. ${ }^{125}$ During one event, a crowd of people that gathered to rescue him after a coach accident ended up mocking his appearance. Surprised by Mirza Saleh's large bulk, long garb, and dyed beard, the crowd called him names such as "landlord of hell," "archangel of torture," and "messenger from the dead." To avoid further humiliation, Mirza Saleh pretended that he did not understand English and remained silent. ${ }^{126}$ While direct complaints about the degrading feeling of being an object of European curiosity are understandably rare in the travel accounts, certain passages reveal the depth of these sentiments. Rezaqoli, for example, relates an incident that occurred in Bath:

Crowds of people of this place, about ten thousand men and women, came below our house to look at us through the windows, where we were standing behind the glass. They continued to do this from morning until night. We, in order to satisfy their curiosity and get rid of their gazing, ordered our Persian servants to go out of doors, that they might see them. As soon as the servants went out, they were surrounded by vast crowds, about twenty thousand, and all the streets were full. At last the servants could bear it no longer, and were obliged to re-enter the house. ${ }^{127}$

Being close to the princes, Fraser also provides some insight into how they felt about becoming part of the never-ending exhibit in Europe. Vali, as Fraser puts it, "was rather provoked at being so constantly stared at." 128

The travelers seem to have become particularly provoked when they sensed that their personal image, like their national identity, was being skewed by the prejudices of European spectators. In this regard, they were confronted by artifacts such as the following anonymous poem, circulated widely through the press in reference to Abolhasan:

The Persian Ambassador's come to town;

Heigho! Says Boney:

And he is a person of rank and renown....

To see the Ambassador all the Folks ran; 
Heigho! Says Boney:

He has sixty-three children, says Boney; well done!

What a dev'l of a fellow! While I haven't one! ${ }^{129}$

As the satirical poem suggests, many of the spectators assumed that Abolhasan practiced polygamy; others considered him to be a sun worshiper. ${ }^{130}$ Neither of these, of course, was true. Such prejudices and assumptions were not always intentional affronts. For example, while trying to be agreeable to Abolhasan's "oriental" lifestyle, some of his hosts would attempt to arrange his rooms in an Ottoman fashion - which was probably inauthentic, but was also definitely irrelevant to the Iranian ambassador. ${ }^{131}$

The scholar Timothy Mitchell has pointed out that intrinsic to modernity is an exhibitionary nature. Its drive is to celebrate the human-ordered world one that is ordered so as to represent. Every phenomenon, from natural forces to cultural norms, should be organized, engineered, controlled, calculated, and arranged to fit into the "the world-as-exhibition." 132 Curiosity itself was to be displayed in such a fashion; there was an institutional order even for bizarreness. But whether in the zoo or in a masquerade ball, the Persian travelers still could not escape from being the focal point of attention, even compared to caged beasts and costumed people. In front of a cage of wild hogs in a zoo, for example, Vali, "was annoyed at the crowd of gazers" who stared at the him; "he could not find a spot to sit down upon in private (khelwut)." ${ }^{133}$ Similarly, while attending a Caledonian costume ball full of people in outlandish dress, Rezaqoli and his brothers, wearing their regular Persian clothing, found that all eyes were upon them. ${ }^{134}$ In a society where, as Steven Spielberg suggests in E.T., an extraterrestrial being can remain unnoticed at a Halloween party, attracting concerted spectatorship requires a particular sort of oddity. The Persian travel writers seemed to qualify for this sort of attention, indicating that they were not just an "ordinary" spectacle, but were somehow violating their designated position within the ordered world of European modernity. As the travelers felt at the time, and as still seems to be the case today, objects of curiosity that did not comply with the imposing order of "Western" modernity were assigned a taint of inherent "backwardness" and/or recalcitrance.

Pursuing refuge from this imposed structure of representation, the travelers at times sought out a kind of invisibility. Rezaqoli, in Fraser's estimation, "experience[d] a sensation of shame, like one who knows he is committing an unworthy action," and frequently tried to "hide himself from view." 135 The travelers intuitively understood that such a disappearance from the European gaze could help to restore them to an authoritative position, even as it heightened their separation from the Farangi world. ${ }^{136}$ Writing about their visit to a military maneuver in Rochester, Fraser observes how the princes sought out a location that would allow them to "view the manoeuvre at their ease ... without being themselves exposed either to the heat of the sun or gaze of the crowd." 137 
The desire to remain unnoticed placed pressure on the travelers to suppress the symbols of their Persian selfhood, including their appearance, their outfits, and their habits of life. The tension between this potential loss of identity and the violation they felt from voyeurs posed a very real and serious concern to the travelers. Fraser notes that Rezaqoli asked his opinion on this matter: "When you are going to take up your abode with any people, is it not well to adopt their costume, so that you may not be stared at? You would not choose to be always an object to be pointed at by them?" 138 Two decades before the prince posed this question, Mirza Saleh had already come to his own conclusion:

Once I entered the plaza [in Plymouth, England], suddenly the crowds [celebrating George III's birthday], who had not seen anybody dress in such garments, gathered from all around, and in an instant, five hundred people surrounded me. I escaped immediately, took a carriage back home, redressed in English outfits, and returned to the event. No one bothered me anymore. ${ }^{139}$

This unwilling adoption of European garments was quite different in nature from the travelers' attempt to respect European protocols, habits, and customs. Most of the travelers expressed no qualms in learning about and experimenting with European culture, so long as they could do so on their own terms and without sacrificing their own identity. Abolhasan, for example, was reported to have "acquired with great facility our habits of life, and soon became accustomed to our furniture, our modes of eating, our hours, our forms and ceremonies, and even our language." ${ }^{140}$ Morier also confirmed "the facility with which he adopts foreign manners and costumes" 141 (while perhaps evincing bit of dread towards the subversive potential of such acts of "mimicry"). ${ }^{142}$

European manners and garments allowed the travelers to seek invisibility from the spotlight that the exhibitionary order of European modernity had put on them and to regain the position of spectatorship towards Farangestan. Another strategy also enabled them to reclaim such position: the act of travel writing. One of the functions that writing served for these travelers was that it allowed them to recover the position of empowered observer that was threatened by the prejudices of the European gaze. Travel writing responded to their need to separate themselves from the European world and to render it as an object of representation, and to thus feel hegemonic over an enchanted audience.

\section{The reincarnated image}

"Here begins the New World," 143 cried Abolhasan upon seeing American coasts - and so began a new horizon for Iran's vision of the foreign Other. During the following decades, as the mutual contact between Iran and Europe increased, the concept of Farangestan gradually narrowed and became 
identified with the specific geographic image of the "West." At the same time, however, the vision of a Farangi wonderland reincarnated into a new body, yengeh donya. Originating from the Azeri term yeni dünya, the phrase literally means "the New World." By the late nineteenth century, this term had become widely used throughout the Middle East to refer to the wondrous land of America. ${ }^{144}$ Iranian curiosity about this yet-more-distant New World had accumulated for many decades, and the increasing contact with Europe provided an opportunity to seek answers about this new horizon.

Farrokh-Khan was reported to have undertaken "a long conference with the American Minister in Paris," 145 but he remains quite silent about this in his writing. Mirza Saleh, in contrast, dedicates several pages of his memoir to discussing America, from its discovery to its independence. ${ }^{146} \mathrm{He}$ describes aspects of the continent's geography, population, political systems, religion, slavery, industry, and exports. Unlike his historical and geographic writing on Britain, France, Russia, and the Ottoman Empire, Mirza Saleh's account of yengeh donya is not well positioned within the organizational structure of his journal, revealing his personal curiosity about the subject.

Rezaqoli, likewise, had a healthy curiosity about yengeh donya, which can be seen in references scattered throughout his memoir. America for Rezaqoli is a source of mystery. It is bigger than the other three corners of the world, surrounded by the most dangerous seas, and bordered on the north by dark and cold territories. Its native inhabitants live in forests and caves, and they eat human flesh. ${ }^{147}$ Rezaqoli saw America as an exotic land full of wild nature, untouched landscapes, and rich mines of gold and silver. The most peculiar wildlife that he observed in horticultural and zoological gardens in Europe, whether gigantic plants or wild beasts, seems to always have come from yengeh donya. ${ }^{148}$ Rezaqoli also suspects that prosperity and industry in this magnificent New World would soon surpass that of Europe. He explains, "Because of the abundant land and water in yengeh donya and the American states, people can cultivate any product. They have also adopted technologies and inventions from all nations." ${ }^{149}$ America thus stands as a new symbol of progress and freedom:

There is more liberty and freedom in yengehb donya than in England and France. This is the secret to their excessive progress as well as the reason why so many people from different countries migrate there. No technology or industry exists in Farangestan that is not better accomplished in yengehh donya. . . Because of their liberty, freedom, and mashverat-e omum [literally, "public consultation"] their strength shall soon surpass all countries. Some of their lands are still occupied by the British, the French, and the Spanish, yet not only shall they soon retrieve their land but also claim beyond their borders. ${ }^{150}$

The English translation of Rezaqoli's travel account contains an entirely new section about America that somehow does not exist in the original Persian publication. In these pages, information about the New World's 
discovery, geography, dimensions, population, and governing systems is elaborated with details about the lengths of major rivers, the heights of prominent mountains, and the areas of important lakes. ${ }^{151}$

For the most part, the travelers shared a dichotomous vision of yengeh donya as both a land of utter savagery and as the ultimate site of progressive civilization. The glue that allowed those contrasting images to cohere was that in both aspects America took on a wondrous status, one that was in total contrast with the travelers' concept of "normal." Thus, yengeh donya gradually replaces Farangestan as the new medium upon which Iranians could project their fantasies of an exotic land. Earlier in this chapter, through cases such as Beirut, St. Petersburg, and Istanbul, I discussed how the travelers gradually pushed their image of the Farangestan further into the distance. Apparently, as the authors became more familiar with Farangestan during their travels, their wondrous imaginations required a more distant and mysterious locale to adhere to: yengeh donya thus served as the new site that housed their homeless ideals.

Would this dialectical cycle of demystification and then reincarnation of the ideal continue after yengeh donya was also discursively discovered by Iranian travelers? Abolhasan's journal allows for general speculation into this matter, since he and his attendants also visited the New World, being perhaps the very first Iranians to do so. ${ }^{152}$ Some scholars believe that yengeh donya was not an intentional connection during Abolhasan's return to Iran, but that their ship was in fact diverted from its course as a result of a severe storm. ${ }^{153}$ This is a highly questionable claim, as neither Abolhasan's journal nor the writings of his multiple companions mention such an event. ${ }^{154}$ In any case, all accounts agree that Abolhasan did eventually make his way to South America, either by accident or on purpose, which gives us an opportunity to examine how his preconceptions of yengeh donya were altered once he set foot on the continent. Prior to this arrival Abolhasan's journal evinces the same wondrous image of America that can be found in the other memoirs, including references to ships of gold, curious plants (probably hemp), and wild beasts, including a tiger with black-and-white stripes. ${ }^{155}$ Curiously, Abolhasan's memoir becomes quite silent about yengeh donya after he visits the continent. It is true that his stay at Cape Frio and Rio de Janeiro was a rather short one, but similar stops at Gibraltar and Malta were elaborated with considerable detail in his journal. Thus it seems a bit of a mystery that Abolhasan would have so little to say about his experience of the New World.

Fortunately, Abolhasan's reaction to yengeh donya was documented for posterity by his companion Morier, and this account may to some extent explain why the Iranian ambassador preferred not to elaborate on his experience of the New World. Morier writes:

As we approached the shore [of Cape Frio] we called the Persians to look at the Yengehe Duniah [yengeh donya], or the new world, of which in their country they had heard such wonders, and upon the subject of 
which they were prepared to believe any thing, however marvellous. They seemed, in consequence, disappointed to behold nothing but common land and common trees, and exclaimed, that it was odd that the new world should be just like the old. ${ }^{156}$

By introducing this segment on yengeh donya, I hope to indicate how the preconceived image of a wondrous, unknown, and far-away Farangestan resisted the disappointment of reality and instead claimed a new body, yengeh donya, as the Iranians adjusted to the materiality of Europe. Further analysis of yengeh donya's image and how it was negotiated by later Persian travelers is a keen subject of interest, but it is beyond the scope of this book.

\section{Notes}

1 Rudyard Kipling, The Ballad of East and West.

2 Mirza Saleh Shirazi, Majmueh Safarnameha, 48, 49, 54, 76, 78, 84, 416.

3 Rezaqoli Mirza, Safarnameh, 216, 239.

4 Aminoddowleh, Makhzanol Vaqaye', 313, 404.

5 Shirazi, Majmueh Safarnameha, 102.

6 Rezaqoli Mirza, Safarnameh, 488.

7 Journal of a Residence, 494.

8 Abolhasan Ilchi, Heyratnameh, 130, 141, 143, 150, 154, 294, 346; A Persian at the Court, 137, 217.

9 Heyratnameh, 121, 147, 268.

10 Ibid., 303, 343.

11 Shirazi, Majmueb Safarnameha.

12 Rezaqoli Mirza, Safarnameh, 393.

13 Aminoddowleh, Makhzanol Vaqaye', 324.

14 Rezaqoli Mirza, Journal of a Residence, 285.

15 Fraser, Narrative of the Residence, 121.

16 Aminoddowleh, Makhzanol Vaqaye, 288. For more information about the tekyeh, see Jean Calmard, "Hosayniya."

17 Aminoddowleh, Makhzanol Vaqaye', 158.

18 Ibid., 167.

19 Christopher Alexander, Sara Ishikawa, and Murray Silverstein, A Pattern Language.

20 Rezaqoli Mirza, Safarnameh.

21 Fraser, Narrative of the Residence, 132.

22 For a description of Naseraddin Shah's painting style and samples of his art, see Mohammad-Reza Behzadi and Nasrin Marjani, "Mashgh-e Shahaneh."

23 For more information about Persian traditions of miniature painting, see Basil Gray, Persian Painting; Norah M. Titley, Persian Miniature.

24 Confronted with the challenge of describing the grandeur of Farangi architecture, Rezaqoli adopts quantitative methods:

In short, if a man does not see it, he could not believe any description of it. The outside of this church all round, and the inside consists of four quarters; each of them is two hundred feet long, and fifty feet broad; the church is three hundred feet high.

(Rezaqoli Mirza, Journal of a Residence, 269)

25 Shirazi, Majmueh Safarnameha, 109. 


\section{When worlds collide}

26 Ibid., 79.

27 Aminoddowleh, Makhzanol Vaqaye', 329.

28 Rezaqoli Mirza, Journal of a Residence, 259.

29 Shirazi, Majmueh Safarnameha, 6, 18, 36, 188, 272, 283, 352. Ilchi, Heyratnameh, 251, 346; A Persian at the Court, 64, 92, 133, 194. Rezaqoli Mirza, Safarnameh, 152, 336, 369, 406, 411, 450, 462, 486, 488. Aminoddowleh, Makhzanol Vaqaye', 206, 215, 230, 257, 262, 272.

30 Ilchi, Heyratnameh, 287-290.

31 Shirazi, Majmueh Safarnameha, 272.

32 M.R. Ghanoonparvar, In a Persian Mirror, 2.

33 Fraser, Narrative of the Residence, 50, 51.

34 La vue d'optique in French and Sundiuq al-dunya in Arabic.

35 Farrokh Gaffary, "Evolution of Rituals and Theater in Iran," 364.

36 Ilchi, Heyratnameh, 66, 127, 128, 285; A Persian at the Court, 35, 183, 224.

37 Naghmeh Sohrabi, Taken for Wonder, 36.

38 See Carter Vaughn Findley, "An Ottoman Occidentalist," 22.

39 Rezaqoli Mirza, Safarnameh, 419.

40 Ibid., 228-231.

41 Ibid., 185, 223, 282, 300, 309, 384, 387, 524.

42 Ibid., 268.

43 Ibid., 592, 630, 649, 657.

44 Aminoddowleh, Makhzanol Vaqaye', 52.

45 Ibid., 416. Interestingly, unlike Farrokh-Khan, Abolhasan portrays a "chaotic and unsafe" image of the Ottoman regions from the very beginning of his journey, as soon as he crosses the Iran-Ottoman border (Ilchi, Heyratnameh, 57, 77). This is most likely because Abolhasan had a broader experience with travel in the region prior to penning the memoir that is examined here, and thus he does not identify the Ottomans with his idealized vision of Farangestan. Abolhasan's exaggerated disinterest in the Ottomans was also observed by his companion James Morier, who attributed this attitude to the rivalry between the two nations (James Justinian Morier, A Journey through Persia, 352).

46 Aminoddowleh, Makhzanol Vaqaye', 424, 426.

47 Rezaqoli Mirza, Safarnameh, 215.

48 Aminoddowleh, Makhzanol Vaqaye', 160.

49 For example, Rezaqoli mentions that Europeans lived a savage life only two hundred and fifty years ago (Rezaqoli Mirza, Safarnameh, 229).

50 Aminoddowleh, Makhzanol Vaqaye', 171.

51 Ilchi, Heyratnameh, 72, 75, 77, 82.

52 Early in his memoir, Abolhasan mentions Farangi law and habit (in singular) but later recognizes different religions (in plural) (ibid., 96, 101, 181, 323).

53 Ibid., 161, 181.

54 Aminoddowleh, Makhzanol Vaqaye', 179.

55 Ibid., 169.

56 Ibid., 162.

57 Shirazi, Majmueh Safarnameha, 78.

58 According to Mirza Saleh: "Because the Russian government attracts business from all of Farangestan's countries, they have appropriately made progress" (ibid., 83).

59 Ibid., 62, 65.

60 Ibid., 49.

61 Ibid., 108.

62 Ibid., 113, 119, 128.

63 Ibid., 115.

64 Ibid., 123.

65 Ibid., 405, 408. 
66 Rezaqoli Mirza, Safarnameh, 224.

67 Ibid., 217; Ilchi, Heyratnameh, 71.

68 Heyratnameh, 48. While most newspaper reports covering Abolhasan's second visit to Europe (for example, "La Belle Assemble.") as well as some scholars (Margaret Morris Cloake, "Forward and Footnotes") believe that the journal's title was bestowed by the Persian Shah, Abolhasan's various references in his journal suggest otherwise (Ilchi, Heyratnameh, 22, 215).

69 Abolhasan writes in his journal: "I asked Mr. Morier for a detailed and thorough description of Europe, which I have recorded in this book, in order to raise awareness amongst travelers and to arose their heyrat" (Heyratnameh, 90).

70 Rezaqoli Mirza, Safarnameh, 305.

71 Ibid.

72 Ibid., 273.

73 Fraser, Narrative of the Residence, 76.

74 Rezaqoli even provides a lengthy description of the cathedral before personally seeing the building that is based on the reports of his brother, Vali (see Rezaqoli Mirza, Safarnameh, 355-359).

75 Rezaqoli was occupied and did not personally visit the zoo, yet he dedicates ten pages of his diary to a detailed description of its wonders (see Ibid., 373-383; also see Fraser, Narrative of the Residence, 96).

76 Sohrabi, Taken for Wonder, 43.

77 James Justinian Morier, “The Mirza Abul Hassan,” 300.

78 A Journey through Persia, 354.

79 Sohrabi, Taken for Wonder, 34.

80 Ilchi, Heyratnameh, 109.

81 Rezaqoli Mirza, Safarnameh, 387.

82 Fraser, Narrative of the Residence, 118.

83 Rezaqoli Mirza, Journal of a Residence.

84 Fraser, Narrative of the Residence, 119.

85 Shirazi, Majmueh Safarnameha, 335.

86 Ilchi, A Persian at the Court, 172.

87 Heyratnameh, 162, 256, 260.

88 Ibid., 61, 79, 124, 131, 156, 165, 230, 293.

89 Rezaqoli Mirza, Safarnameh, 438.

90 Ilchi, Heyratnameh, 245.

91 A Persian at the Court, 261.

92 Aminoddowleh, Makhzan Al-Vaqayi, 338.

93 Rezaqoli Mirza, Journal of a Residence, 295.

94 Fraser, Narrative of the Residence, 213.

95 Aminoddowleh, Makbzanol Vaqaye', 189.

96 Shirazi, Majmueh Safarnameha, 115.

97 Cloake, "Foreword and Footnotes."

98 Rezaqoli Mirza, Safarnameh, 405. Farrokh-Khan similarly uses the allegory of "glass mountain" to describes the Crystal Palace (see Figure 3.2 and 4.2; Aminoddowleh, Makhzanol Vaqaye’, 340).

99 Ilchi, Heyratnameh, 270.

100 A Persian at the Court, 224.

101 Rezaqoli Mirza, Journal of a Residence, 303. The travelers' prioritization of a magical rendering of modern wonders, rather than detailed discussions of their construction techniques, has an interesting parallel in Arab literature. 'Aja'ib, a literary genre common in the medieval period, emphasized expressions of wonderment towards marvelous objects, and is regarded as corresponding to a decrease in scientific curiosity in favor of the "popular interest in amusing literature” (Cesar E. Dubler, “Adja'ib”). 
102 Rezaqoli Mirza, Safarnameh, 690; Aminoddowleh, Makhzanol Vaqaye’, 424, 426.

103 Makhzanol Vaqaye', 336, 343, 402.

104 Ilchi, Heyratnameh, 178; A Persian at the Court, 222.

105 Heyratnameh, 333. A Persian at the Court of King George, 239

106 Charles Lamb, The Letters of Charles Lamb, II, 90.

107 Cited in Cloake, "Foreword and Footnotes," 61, 171, 295.

108 Ilchi, A Persian at the Court, 112.; Heyratnameh, 330.

109 Heyratnameh, 113.

110 Ibid., 123.

111 Ibid., 142.

112 Fraser, Narrative of the Residence, 83.

113 Rezaqoli Mirza, Safarnameh, 320, 344, 593, 604, 628.

114 Fraser, Narrative of the Residence, 15.

115 Assaad Y. Kayat, A Voice from Lebanon, 119.

116 See Jacques Lacan and Bruce Fink, Ecrits.

117 Ilchi, Heyratnameh, 350.

118 This increasing national consciousness was reflected in the larger Iranian society during the same time period, especially as a result of adversarial contacts with Russia and a growing curiosity about Farangestan. During the following years this sensibility encouraged the revitalization of the "Aryan" architecture of the Qajars. For more information, see Talinn Grigor, "Orient Oder Rome?"

119 Farangi vendors "have 'two' prices;” says Kayat, "and this I discovered by changing my dress and going out at night in an European garb" (Rezaqoli Mirza, Journal of a Residence, 126).

120 Sohrabi, Taken for Wonder, 43.

121 Ilchi, Heyratnameh, 172, 335. In one instance, Abolhasan mentions that although he was genuinely interested to try ice skating, he eventually chose not to do so to escape the crowd's possibly unpleasant reaction (ibid.). For other instances where Abolhasan expresses annoyance about how his appearance distracted women and children, see A Persian at the Court, 99; Heyratnameh, $131,183$.

122 "Ministerial Banquet at the Mansion-House."

123 Aminoddowleh, Makhzan Al-Vaqayi, 173, 243.

124 Farrokh-Khan explains his intention in changing his outfit as a way to gain more "freedom" in his trip to Italy. Whatever the reason, it is interesting that he felt an obligation to provide an explanation about his choice, as if otherwise it would not have been an acceptable behavior (see ibid., 393).

125 Shirazi, Majmueh Safarnameha, 150.

126 Ibid., 350.

127 Rezaqoli Mirza, Journal of a Residence.

128 Fraser, Narrative of the Residence, 87.

129 "The Persian Ambassador by the Town Crier."

130 Gilbert Elliot Minto, Lord Minto in India.; Ilchi, Heyratnameh, 176.

131 A Persian at the Court, 171, 227.

132 Timothy Mitchell, "The World as Exhibition."

133 Fraser, Narrative of the Residence, 96.

134 Ibid., 103, 104.

135 Ibid., 104.

136 As Mitchel puts it, "The ability to see without being seen confirmed one's separation from the world, and constituted, at the same time a position of power" (Mitchell, "The World as Exhibition," 306).

137 Fraser, Narrative of the Residence, 171.

138 Ibid., 55. 
139 Shirazi, Majmueh Safarnameha, 189.

140 "Meerza Abul Hassan."

141 "Extraordinary Particulars."

142 In multiple occasions, Morier reminds his readers about how Ilchi "soon accommodated himself to the manners of ship, sleeping in cot, and eating with a knife and fork" (ibid.). For more on the politics of mimicry, see Homi Bhabha, "Of Mimicry and Man.”

143 Ilchi, Heyratnameh, 368.

144 Yengeh donya, according to an 1876 article in the Saturday Review was "the phrase for America current all over the east" ("Fogg's Arabistan," 117).

145 "Foreign Intelligence."

146 Shirazi, Majmueh Safarnameha, 243-249.

147 Rezaqoli Mirza, Journal of a Residence, 146, 240.

148 Safarnameh, 370, 375, 377, 380, 519.

149 Ibid., 526.

150 Ibid., 573, 574.

151 Journal of a Residence, 146-151.

152 See Hasan Javadi, “Abu'l-Ḥasan Khan İlč̌̃."

153 Ibid.

154 See William Ouseley, Travels in Various Countries of the East: More Particularly Persia, I; James Justinian Morier, A Second Journey through Persia.

155 Ilchi, Heyratnameh, 100, 124; A Persian at the Court, 215, 225, 271.

156 Morier, A Second Journey through Persia, 3.

\section{References}

Alexander, Christopher, Sara Ishikawa, and Murray Silverstein. A Pattern Language: Towns, Buildings, Construction. New York: Oxford University Press, 1977.

Aminoddowleh, Farrokh-Khan. Makhzan Al-Vaqayi: Safarnameh-Ye Farrokh Khan-e Aminoddowleh [Aminoddowleh's Travelogue]. Majmu'eh SafarnamehaYe Irani. 2nd ed. Tehran: Asatir, 1994.

- Makhzanol Vaqaye': Safarnameh-Ye Farrokh Khan-e Aminoddowleh [Aminoddowleh's Travelogue]. Majmu'eh Safarnameha-Ye Irani. 2nd ed. Tehran: Asatir, 1994.

Bhabha, Homi. "Of Mimicry and Man: The Ambivalence of Colonial Discourse." Discipleship: A Special Issue on Psychoanalysis 28 (1848): 8.

Calmard, Jean "Hosayniya." In Encyclopedia Iranica, edited by Ehsan Yarshater, 517-518. New York, NY: Columbia University Press, 2004.

Cloake, Margaret Morris. "Foreword and Footnotes." Translated by Margaret Morris Cloake. In A Persian at the Court of King George: The Journal of Mirza Abul Hassan Khan. London: Barrie \& Jenkins Ltd, 1988, 7-11.

Dubler, Cesar E. “Adja'ib.” In Encyclopedia of Islam, 203-204. Leiden: Brill.

Findley, Carter Vaughn. "An Ottoman Occidentalist in Europe: Ahmed Midhat Meets Madame Gulnar, 1889.” American Historical Review 103, no. 1 (Feb 1998): 15-49.

"Fogg's Arabistan." The Saturday Review of Politics, Literature, Science and Art, 1876.

"Foreign Intelligence.” Times, March 141857.

Fraser, James Baillie. Narrative of the Residence of the Persian Princes in London, in 1835 and 1836. The Middle East Collection. New York: Arno Press, 1973. 
Gaffary, Farrokh. "Evolution of Rituals and Theater in Iran.” Iranian Studies 17, no. 4 (Autumn, 1984): 28.

Ghanoonparvar, M. R. In a Persian Mirror: Images of the West and Westerners in Iranian Fiction. 1st ed. Austin: University of Texas Press, 1993.

Gray, Basil. Persian Painting. London: E. Benn, 1930.

Grigor, Talinn. “Orient Oder Rome? Qajar 'Aryan' Architecture and Strzygowski’s Art History.” Art Bulletin LXXXIX, no. 3 (2007): 28.

Ilchi, Abolhasan. Heyratnameh: Safarnameh-Ye Mirza Aolhasan Khan-e Ilchi Beh Landan [Wonderlogue: The Accounts of Ambassador Abolhasan Khan's Travel to London]. 1st ed. Tehran: Moasseseh-ye Khadamat-e Farhangi-ye Rasa, 1986.

- A Persian at the Court of King George: The Journal of Mirza Abul Hassan Khan. Translated by Margaret Morris Cloake. London: Barrie \& Jenkins Ltd, 1988.

Javadi, Hasan. "Abu'l-Ḥasan Khan Īlčī: Persian Diplomat, B. 1190/1776 in ŠĪrāz.” In Encyclopcedia Iranica, edited by Ehsan Yarshater, 308-310. New York: Columbia University Press, 1983.

Kayat, Assaad Y. A Voice from Lebanon with the Life and Travels of Assaad Y. Kayat. London: Madden \& Co., 1847. Texto impreso.

Kipling, Rudyard. The Ballad of East and West. New York: Alex Grosset, 1889.

Lacan, Jacques, and Bruce Fink. Ecrits: The First Complete Edition in English. New York: W.W. Norton \& Co., 2006.

Lamb, Charles. The Letters of Charles Lamb. Vol. II, London: Dent and Methuen, 1935.

Marjani, Mohammad-Reza, and Behzadi Nasrin. "Mashgh-e Shahaneh: Moraghgha'at-e Naghghashi Naseraddin Shah-e Ghajar Dar Ketabkhaneh-Ye Saltanati-Ye Sabegh [Royal Sketches: Naseraddin Shah's Drawings]." Tarikh-e Mo'aser-e Iran no. 60 (2012): 269-332.

"Meerza Abul Hassan.-No. Ii." The Penny Magazine of the Society for the Diffusion of Useful Knowledge, October 25 1834: 2.

"Memoirs of the Persian Ambassador." La Belle Assemble: Or Court and Fashionable Magazine, June 1819, 2.

"Ministerial Banquet at the Mansion-House." Times, March 21, 1857.

Minto, Gilbert Elliot. Lord Minto in India: Life and Letters of Gilbert Elliot, First Earl of Minto, from 1807 to 1814. London: John Murray, 1880.

Mitchell, Timothy. "The World as Exhibition." Comparative Studies in Society and History 31, no. 2 (1989): 217-236.

Morier, James Justinian. "Extraordinary Particulars in the Life of Mirza Abul Hassan." La Belle Assemble: Or Court and Fashion Magazine, December 1811.

- A Journey through Persia, Armenia, and Asia Minor, to Constantinople, in the Years 1808 and 1809: In Which Is Included, Some Account of the Proceedings of His Majesty's Mission, under Sir Harford Jones . . To the Court of the King of Persia. London: Printed for Longman, Hurst, Rees, Orme, and Brown . . 1812.

- "The Mirza Abul Hassan." In The Adventurer of the 19th Century, Issues 1-37, 298-301. London: Knight and Lacey, 1823.

. A Second Journey through Persia, Armenia, and Asia Minor, to Constantinople, between the Years 1810 and 1816: With a Journal of the Voyage by the Brazils and Bombay to the Persian Gulf: Together with an Account of the Proceedings of His Majesty's Embassy under His Excellency Sir Gore Ouseley. London: Longman, Hurst, Rees, Orme, and Brown, 1818. 
Ouseley, William. Travels in Various Countries of the East: More Particularly Persia. 2 vols. Vol. I, London: Rodwell and Martin, 1819.

"The Persian Ambassador by the Town Crier." The Statesman, January 251810.

Rezaqoli-Mirza. Journal of a Residence in England, and of a Journey from and to Syria, of Their Royal Highnesses Reeza Koolee Meerza, Najaf Koolee Meerza, and Taymoor Meerza, of Persia, to Which Are Prefixed Some Particulars Respecting Modern Persia, and the Death of the Late Shah. Translated by As'ad Yakub Khayyat. London, Westmead: W. Tyler, Gregg Inter., 1839.

—. Safarnameh-Ye Rezaqoli Mirza Navey-Ye Fath Ali Shah [the Travel Account of Rezaqoli Mirza, Fath Ali Shah's Grandson]. Majmueh Safarnameha-Ye Irani. Edited by Asghar Farmanfarmai Qajar. 3rd ed. Tehran: Asatir, 1994.

Shirazi, Mirza Saleh. Majmueh Safarnameha-Ye Mirza Saleh Shirazi [Series of Travelogues by Mirza Saleh Shirazi]. Nashr-e Tarikh-e Iran. 1st ed. Tehran: Nashr-e Tarikh-e Iran, 1985.

Sohrabi, Naghmeh. Taken for Wonder: Nineteenth-Century Travel Accounts from Iran to Europe. New York: Oxford University Press, 2012.

Titley, Norah M. Persian Miniature Painting and Its Influence on the Art of Turkey and India: The British Library Collections. Austin: University of Texas Press, 1984. 


\section{Imagining the modern}

\section{Mapping modernity}

In his seminal work on The Image of the City, Kevin Lynch described how people create mental maps of urban environments. Lynch studied a handful of prominent American cities in the middle of the twentieth century and identified five mental elements through which their inhabitants interpreted and navigated space - elements that he labeled as paths, landmarks, edges, nodes, and districts. Lynch also pointed out, however, that these five elements were part of a specific historical and geographical experience and that they might change in other contexts or based on the urbanites' specific cultural background. ${ }^{1}$

The Persian travelers examined in this book likewise applied their culturally constructed habits of mental mapping to generate images of the places they visited. While it is difficult from the limited evidence in their memoirs to provide an exhaustive reckoning of the elements involved in the travelers' mental maps of Farangi cities, a certain amount of insight can be gained by examining their writing and its relation to the major urban structures of nineteenth-century Iran. In the context of the travelers' native environment, for example, the sociocultural heart of the typical city of central Iran was the Friday Mosque, while the bazaar served as an economic structure spatially linking the mosque to various neighborhoods. The neighborhoods were then wrapped and shielded by city walls that gave access to the city through strategically located gates. The administrative quarter of the city was likewise contained by barricades. ${ }^{2}$

These established elements of Iranian architecture provided the travelers with only a limited background with which to orient themselves to the new urban features that they encountered during the course of their journeys. In their memoirs, the travelers acknowledge an inadequacy in their preexisting mental categories of spatial division, and they struggle to find ways of mapping the novel elements of European cities. Mirza Saleh, for example, attempts to interpret the cities he encounters in the early portions of his journey by describing their minarets, schools, public baths, and citadels as focal points. Quickly, however, he finds such landmarks to be either nonexistent or insufficient in providing an image of the cities' life and organization, and 
he has to adopt a new vocabulary to represent the different functional layout of Farangi spaces.

Mirza Saleh also begins to introduce a kind of innovative spatial vocabulary to compensate for the inadequate and underdeveloped vocabulary to formulate architectural forms. These descriptions of form are surprisingly rudimentary. He has to construct the peculiar concept of an "elongated square" to refer to the rectangular shape of buildings such as the House of the Lords in Westminster. ${ }^{3}$ Mirza Saleh's other references to architectural form are limited to similar basic shapes, such as descriptions of the hexagon fortress of Peter and Paul in St. Petersburg; the octagon pool in Gardjola Garden, Malta; and the pentagon tombs in Erzurum, Turkey. ${ }^{4}$

The other travelers evince similar struggles in moving beyond generic descriptions of form when writing about Farangi architecture. Abolhasan also has trouble finding a concise vocabulary for rectangular arrangements, and he ends up relying on awkward phrases such as, "a lengthy building having a short width." ${ }^{5}$ However, Abolhasan has substantially more to say in his elaborate description of St. Paul's Cathedral (see Plates 3 and 9), where he specifies, in part: "On each side there were spiral staircases. Half of the building was octagonal and from the middle on it turned circular." $\mathrm{He}$ then goes on to quote a poem specifying that "the superior form is that of a circle," an inclusion that seems to clarify his prejudice towards this particular geometry. ${ }^{6}$ Abolhasan's only other detailed description of architectural form comes in a later passage when he encounters another building with a circular plan. ${ }^{7}$

The scarcity of descriptions of architectural form in the memoirs cannot be considered as merely a linguistic limitation, because the travelers were much more eloquent in writing about geometries in other contexts. Rezaqoli uses many form-describing words when talking about the appearance of shapes in a fireworks display, ${ }^{8}$ but he never brings any of this vocabulary to bear on discussing architectural spaces. Even urban layouts incited clearer images than architectural geometry. Rezaqoli - who occasionally ascended to the heights near a Farangi city to obtain a better view of the savad-e shahr (the silhouette of the city) ${ }^{9}$ - in addition to descriptions of the city's natural context, skyline, and notable landmarks (e.g., the position of church towers), wrote about the cityscape, through formal expression, limited to three shapes: triangle, crescent, and "millipede." ${ }^{10}$ While it is legitimate to argue that architectural forms, particularly as they apply to the building plan, are often taken for granted and are thus not easily detected by non-trained observers, it seems that the majority of Farangi architectural forms were simply not alien enough to fit well into the narrative image that the writers sought to convey to their Persian audience.

The elements of this Occidentalist image of space, similar to what Lynch had discovered, bear no hierarchical order: a mannequin displayed in a shop may be more effective than a cathedral, when mapping space. The 
architectural elements introduced in this chapter may similarly appear hierarchically disorganized; their association should rather be sought in the travelers' mentally generated image of Farangi space, which although disordered, fragmented, and even contradictory in its details, sought coherence from utopian models.

\section{A kucheh-bagh to progress}

As discussed in the previous chapter, during the course of their journeys, the travelers mastered more complex linguistic tools to express spatial qualities. Yet, as this improved lexicon became more vivid and complex, instead of a rendering a more accurate image of European space, it enabled the travelers to better articulate their utopian expectations of Farangestan. For example, Mirza Saleh, in the earliest portions of his journal, has a straightforward approach to evaluating streets: they are either hamvar (smooth) like the ones in Russia and England or nahamvar (uneven) like the rocky and rough roads of Iran and Turkey. ${ }^{11}$ As his trip advances, he gradually adopts a broader vocabulary to convey the same impression, stating that the streets in Moscow as "wide, paved, and clean," while those of lesser cities are "narrow and filthy." 12

Interestingly, it is precisely these same three adjectives that are adopted forty years later by Farrokh-Khan to describe the streets of both Naples and Messina, shortly after his arrival in Europe. In these passages, the inseparable adjectives of "wide, paved, and clean" become expressions not only of approval, but of what had by then become an expected Occidental ideal. These words continue to be used in various combinations and alongside other terms of praise throughout the memoir. For Farrokh-Khan, the wide, paved, clean (and also straight) street is synonymous with the good street. The adjectives sit next to words such as "desirable," "excellent," and "good"; in Antwerp, Belgium, FarrokhKhan describes the city as "a very desirable town with straight and paved streets, excellent buildings, and good stores." ${ }^{13}$ A similar combination of adjectives appears quite often to describe roadways in Abolhasan's memoir. In fact, the city streets are the first features that Abolhasan writes about after setting foot in England: "When we arrived at Plymouth, we saw long roads that had no curve whatsoever, and they were paved with marble." 14

The image of the ideal Farangi street as wide, paved, clean, and straight is at least partially rooted in the contrast between self and Other. In premodern Persian cities within hot and arid regions (including Kashan, which was Farrokh-Khan's hometown, and Shiraz, which was home to the other three travelers), the organic layout of city streets is typically narrow and very often curved, as an adaptation to harsh weather conditions. The narrowness of city streets allows for more shade, while their curvature decreases 
the flow of dust storms. Furthermore, Persian streets at the time were rarely paved and on rainy days, however seldom, they became quite muddy. One of Farrokh-Khan's descriptions of European roads shows how this cultural background informed his interests:

The effort that has been put into pavement [in Farangestan] is beyond human scope. Vast areas of land are excavated and filled with lime and stone, so even if it rains all year long, there will be no sign of mud, holes, or bumps. ${ }^{15}$

Similar sentiments about the extravagance and splendor of paved roadways are expressed by Rezaqoli ${ }^{16}$ and Mirza Saleh.

The qualities of Farangi streets that the travelers praised rendered an image that was not quite unfamiliar to their Iranian audience - the kucheh$b a g h$. This elegant architectural feature is basically a linear orchard aligned along the sides of an alleyway, designed according to the principles of charbagh, the Persian garden. ${ }^{17}$ A fountain often runs through the middle of the kucheh-bagh, creating an opulent and charming atmosphere (see Figure 4.1). This specific, lavish architectural pattern was sought after and presented by the travelers in their idealization of Farangi roadways. The streets of Bath, for example, appeared as a rose garden to Abolhasan, who expresses particular admiration for the streams that passed along each side. ${ }^{18}$ Abolhasan also praised the streets in Kensington Gardens, London, for their width and their symmetrically positioned rows of trees. ${ }^{19}$ Rezaqoli makes the comparison explicit, describing roadways in Beirut as "continuous kucheh-baghs, which are not bordered by walls but rather by hedges of aloe." ${ }^{20}$ It is notable that the travelers consistently emphasize a stately and tranquil portrait of these streets, while altogether omitting their more raucous or businesslike elements. For example, Rezaqoli who describes the pleasant and charming atmosphere of European city streets and the trees that line them, complained to his Scottish companion Fraser about "the eternal whirr! Birr! Jirr! of its streets, with their thousand carts and carriages, and uproar." 21

The utopian ideal of "wide, paved, and clean" that the Persian travelers describe in their memoirs played an important role in the subsequent trajectory of Iranian urban planning. At least one of the travelers studied here, Farrokh-Khan, was directly involved in implementing this vision of progress after his return to Iran. Serving as the minister of the interior, Farrokh-Khan gave orders to pave the streets surrounding the Royal Arg (citadel) of Tehran with polished cubic stones. ${ }^{22}$ In later years, the Street-Widening Act of 1933 gave rise to a large-scale modernization project that sought to impose a kind of rigorous geometric order in Tehran, leading to the destruction of long-standing city walls and gates, and the creation of new, wide avenues that cut through the preexisting urban fabric. ${ }^{23}$ 


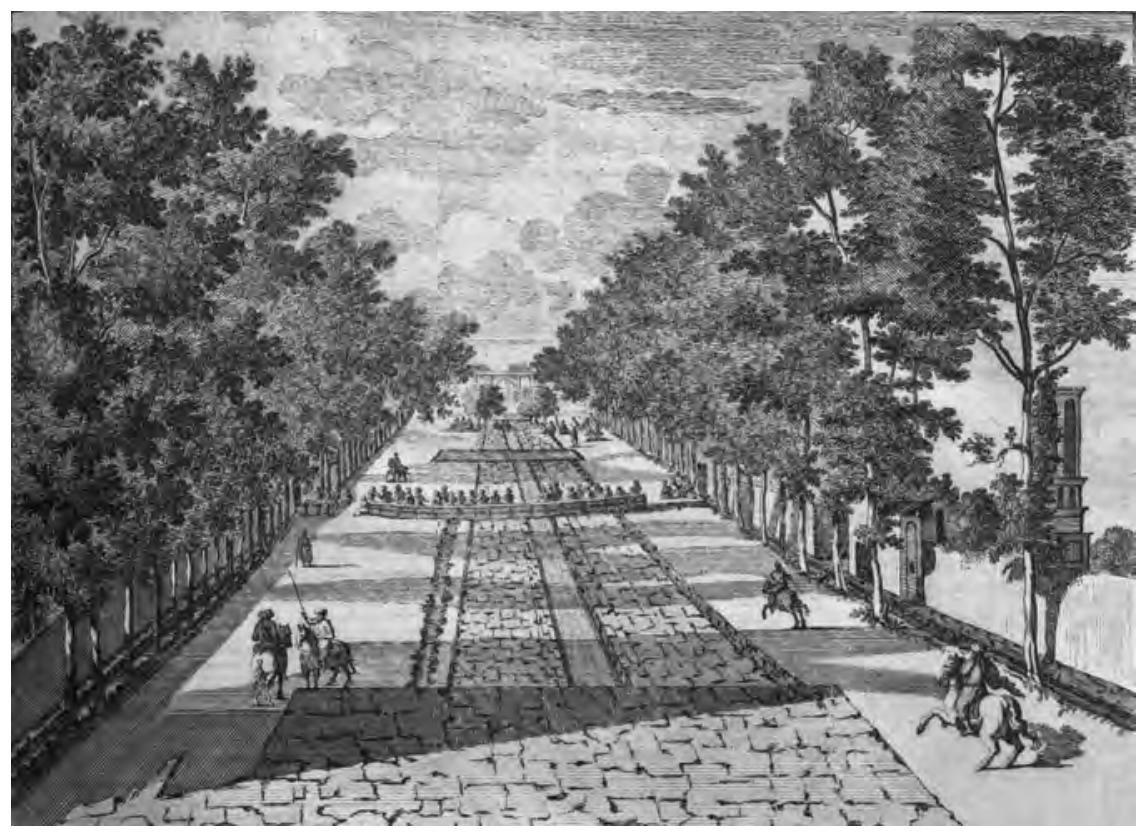

Figure 4.1 The Charbagh of Isfahan, an expansive version of the kucheh-bagh, was designed by Sheykh Baha'i in the early seventeenth century.

Source: Cornelis de Bruyn's 1737 Travels into Muscovy, Persia, and Part of the East Indies.

\section{Refashioning the Farangi house}

The Farangi house attracted the curiosity of the travelers particularly when it negated the archetypal image of their typical Persian homes. This image and the architectural features associated with it are best articulated in Farrokh-Khan's description of the ruins of Pompeii:

The layout of the buildings is like in Iran. First, the houses are one story and each house has a courtyard and a reflecting pool in the middle. Second, the paintings in the rooms are similar to the ones in Iran. Each building has a separate andaruni [the private section of a traditional Iranian house] and biruni [the public part of the interior]; not at all does it resemble the Farangestan design. ${ }^{24}$

Through contrasting his image of Persian homes and his expectations of a Farangi house, Farrokh-Khan introduces many architectural features such as the relationship between mass and space, and public and private; yet the first architectural quality that he expected from Frangi houses was their height. Mirza Saleh Mirza Saleh, who habitually dedicated a portion of his descriptions of European cities to their housing conditions, often started by 
discussing the number of floors that the houses contain. ${ }^{25} \mathrm{He}$ also associated multistory houses with the idea of Farangestan, for example in İzmit, Turkey, where he links the multistory houses to what he calls the "Farangi manner." ${ }^{26}$ But Farrokh-Khan's description of the ancient Roman ruins at Pompeii conveys an additional meaning - one that identifies building heights with progress.

For Farrokh-Khan, ancient Roman architecture is indicative of what we might call a "pre-Farangi" pattern, which in his view was once the norm in Europe and which continues to dominate the Iran of his day. Adding a temporal dimension to the vision of Farangestan allows the traveler to present the concept of historical progress in Europe as an incentive for changes at home. Farrokh-Khan was clearly committed to this vision of the future: after his return from Europe he constructed a new house for himself in Kashan that rose to an unconventional three stories. This building later became the city's divankhaneh (house of justice) and then the governor's office, before eventually being demolished.

In addition to the prevalence of multistory designs, another important aspect of Farangi houses that captured the travelers' imagination, and was emphasized in Farrokh-Khan's comparison between Pompeii and Iran, was the lack of strict segregation between public and private areas within the building. Premodern Persian homes, especially in the hot and arid regions of the country, were built around a rigid separation between the biruni (public area) and the andaruni (private area, known as the harem in Arabic). The andaruni was considered a "safe space" particularly for the women of the family, where they could relax without concern for the threatening gaze of outside men (see Plate 11). The female members of the family, regarded as the most private and precious "possessions" in a patriarchal society, were in Farangestan exposed and accessible to all. The imagined Farangi homes, in contrast, had no such rigid boundaries designating areas that are offlimits to male voyeurism. London's apartments, as Rezaqoli had noticed, contrary to the spatially introverted layout of a typical house in central Iran that have no openings to the outside world, "had glass windows, looking to the streets." ${ }^{27}$ Similar to European women, the unveiled architecture of Farangestan further integrated the interior with the exterior.

As the scholar Mohamad Tavakoli-Targhi has discussed at length in his chapter on Imagining European Women, the perceived accessibility of European women lent itself to a kind of eroticized free-love utopianism, at least in the imagination of male Persian observers: "the eroticized depiction of European women by male travelers engendered a desire for that heaven on earth and its uninhibited and fairy-like residents who displayed their beauty and mingled with men." 28

The allure of enticing and accessible Farangi women led several of the travelers, and numerous members of their retinues, to fall in love during the stay in Europe. ${ }^{29}$ While the imagined Farangi woman reflected the Islamic concept of huri (the beautiful maidens that in Muslim belief live with the blessed in paradise), Farangi architecture was similarly a projection of the 
Islamic paradise -and in this imaginary paradise, no separation of men and women, interior and exterior, public and private, andaruni and biruni, was acknowledged, even if it existed.

The "inverted" nature of Farangi houses, where the hidden and private becomes public and accessible, is often characterized by the travelers' attention to courtyards and gardens. Courtyards are inseparable spaces of Persian houses. The traditional Persian house in hot and arid regions is turned inward upon itself, with a prominent central courtyard that is at once protected from the harsh climate and hidden from the public. The resemblance that Farrokh-Khan sees between Persian buildings and those in Pompeii was in part because he detected "a courtyard and a reflecting pool in the middle." ${ }^{30}$ But when he continues to suggest that this pattern does not "resemble the Farangestan design," he asserts an expectation that in Farangi design, this inner sanctum is shifted to the exterior, as if freely offering the garden's delights to the visitor. This vision of accessibility is a defining feature of the travelers' accounts, in some cases leading them to overlook the actual complexities of the spaces they encountered. While many urban apartments in Paris, Florence, and Brussels, where FarrokhKhan had traveled, also had interior courtyards, he largely ignored those buildings and instead focused on other locations, such as the suburban villas of London, where the courtyards and gardens most frequently surrounded the house.

Farrokh-Khan consistently begins his descriptions of Farangi buildings with a mention of their courtyard, and typically follows up with a remark on the external vegetation. In many instances, this description occupies a larger portion of his discussion than does the actual building. ${ }^{31}$ This interest in external gardens extends to other types of architecture as well: in one case, when describing a mental asylum where there is no sign of a garden at all, Farrokh-Khan commences his description by discussing in detail the flowers and birds painted onto the buildings' exterior walls. ${ }^{32}$

Abolhasan similarly sees the institutional novelty of the Royal Hospital at Greenwich as being secondary to its surrounding parkland and streams. ${ }^{33}$ Mirza Saleh, alone of all the writers discussed here, seems to have a different perspective. While Mirza Saleh also prioritizes the value of courtyards and gardens, he observes that many of the houses in London "have absolutely no garden. The high population and the expensive land price do not allow [for garden spaces]." ${ }^{34}$ This outlook is probably related to the traveler's social class; while the others enjoyed the status of high nobility and were exposed to the suburban villas of their English peers, Mirza Saleh focuses more closely on the average homes of commoners. All of the travelers, however, shared the belief that to explain Farangi buildings, discussions of the surrounding green spaces are inevitable. They characterized the presence of external courtyards as a criterion to evaluate space, as if the heavenly quality of an ideal building can be fulfilled only next to a garden. Farangi 
buildings are "excellent” in Rezaqoli's mind because, "like heaven's palaces, they each sit next to gardens." 35

\section{Rediscovering Eram}

While the concept of the household garden was familiar to and appreciated by the Persian travelers, the experience of open public parkland was completely exotic. The travelers expressed a lively curiosity about public parks, botanical gardens, and zoos, and they recorded the details of these spaces extensively in their journals. ${ }^{36}$ They also remarked on the wide variety of activities and entertainments that the parks hosted for the public, ranging from fireworks to acrobatics.

Similar to their interest in private gardens and public parks, the travelers were intrigued by the natural landscapes of Europe in general, and they did not hesitate to ascribe the label of "garden" to these broader scenic spaces. ${ }^{37}$ Certainly they were struck by the contrast of European greenery to the sparseness of their own homeland. Given the hot and arid climate that covers a wide region of the Iranian plateau and the scarcity of water, lush and verdant gardens would be considered a rare luxury. This background explains the travelers' amazement at Farangi landscape in which their eyes "did not see a single handbreadth of earth, but all [was] covered with delightful green." 38 This statement, taken from the journal of Rezaqoli, was made after his initial nighttime landing in Europe; he had not yet seen a single Farangi city nor viewed the landscape in the daytime. Still, he spoke with poetic wonder about the verdant land as "the first story of paradise," filled with "roses and all kinds of flowers, guarded by the nightingales' singing." 39

Rezaqoli and his brothers were outdoor enthusiasts; they constantly sought to escape from the city into the wonders of the countryside. ${ }^{40}$ In one case, when the brothers were visiting the rural estate of Sir Henry Willock (formerly the British ambassador to Iran), Fraser reports that:

The princes were delighted with the situation, the running stream and the cool freshness of the air. "Vah! Vah!" said they, snuffing it up, and running from flower to flower like bees or butterflies, "who would live in London, with all its dust, and its heat . . . when they could come to such a place like this? This is the true spot for dwelling; here you have the full Dil-gousha - the opening of the heart; one dies of pleasure here." 41

Not only did the travelers prefer the natural environment to a modern urban setting, they also wanted to domesticate it by practicing their Persian picnic habits. Fraser's report of the party held at Willock's house presents another quotation from Rezaqoli and his brothers: “Ah! There is the spot for us, there, just under 
these trees: now a carpet on the grass, and plenty of good wine - that is the way we should do in Persia." ${ }^{42}$ Similar perspectives of domestication are revealed in other passages; for example, at the horticultural gardens at Chiswick:

[Rezaqoli's brother, Vali] walked upon the velvet turf, and went up to the rose-bushes, every flower and bud of which he touched and petted with his hands, and expressed considerable satisfaction ... [saying] "if this were Persia now, how differently would these people be employing themselves on this turf, which is like velvet, and among this gush of flowers and rich verdure! Not one spot, not a bush would there be without its party seated in the shade, drinking their wine to the sound of instruments." 43

Poetic descriptions of nature are pervasive in Rezaqoli's diary, where Farangastan is depicted as a land of majestic public gardens, splendid flowers, fresh air, excellent fountains, fine fruits, red roses, singing nightingales, elegant trees, and colorful blossoms. Rivers are like the rosewater that runs down the cheeks of virgins, and the scent of flower blossoms nourishes the soul like the breath of Jesus. ${ }^{44}$ Such is the vision of the Farangi paradise that takes shape in the prince's journal. While Rezaqoli was perhaps the most eloquent of the travelers in his descriptions of natural wonder, the others were not immune to its appeal. Even Mirza Saleh, who usually insists on a cold and scholarly tone, could not escape the temptation of sentiment when writing about gardens, and the only use of poetry in his memoir occurs as part of his description of a natural landscape. ${ }^{45}$

The appreciation of natural and rural landscapes over urban space was similarly shared by Abolhasan. Morier had observed that Abolhasan and his servants, who were unexpectedly indifferent towards the urban novelty of Istanbul, "were very keenly alive to the beauties of nature, and enjoyed much the shade of trees and the refreshing sound of running water." ${ }^{46}$ Abolhasan, who got sick several times in London, sought refuge in the countryside, where he wrote about the pleasantness of the weather and the vegetation: "it is all greenery, as the rose-garden of Eram; nothing like London." ${ }^{47}$ This reference to Eram, a mythical city romanticized in Persian literature, reveals the extent to which the travelers tended to locate the most ideal aspects of Farangestan in its rural and suburban areas. The imagery of Eram appears many times in Abolhasan's account, most often in descriptions of elite county houses. In one passage, for example, at the Neo-Palladian Chiswick House, where again, the description of the delightful garden, its pine trees, and its stream, precede the architectural discussions, he writes:

Three miles from London, we arrived at a perfect house with a large garden.... We enjoyed a pleasant walk through woods of juniper, box, and spruce, which matched the gardens of Kashmir and the rose-garden of Eram. . . . Such areas that have many trees, like the lush jungles of Gilan, are called "the country." 48 
The association of Farangi public spaces with heavenly garden of Eram becomes even more interesting, however, when we consider the following passage taken from Farrokh-Khan's memoir:

Shaddad's paradise [another name for the mythical garden-city of Eram] is only a sample of this building. Upon my entrance to the space and observing the situation, I was so astonished that I couldn't realize where I was and what had happened. It was the flower-garden of Eram! On each side the beautiful branches and leaves of trees embraced each other, with various flowers. Their leaves were woven together, fresh and joyful, and colorful birds were singing in different chords, and glass fountains were jumping high on all sides. ${ }^{49}$

The imagery in this passage is taken directly from long-standing, idealized concepts of the Persian garden. It is therefore astonishing to realize that the space thus described is Joseph Paxton's Crystal Palace, an icon of modern architecture originally built to house London's Great Exhibition of 1851 (see Figures 3.2 and 4.2). Crystal Palace was celebrated at the time for being the world's largest enclosed building, for its innovative use of cast-iron and glass, and for representing the triumph of engineering over nature. In Farrokh-Khan's estimation, however, it becomes yet another vision of the

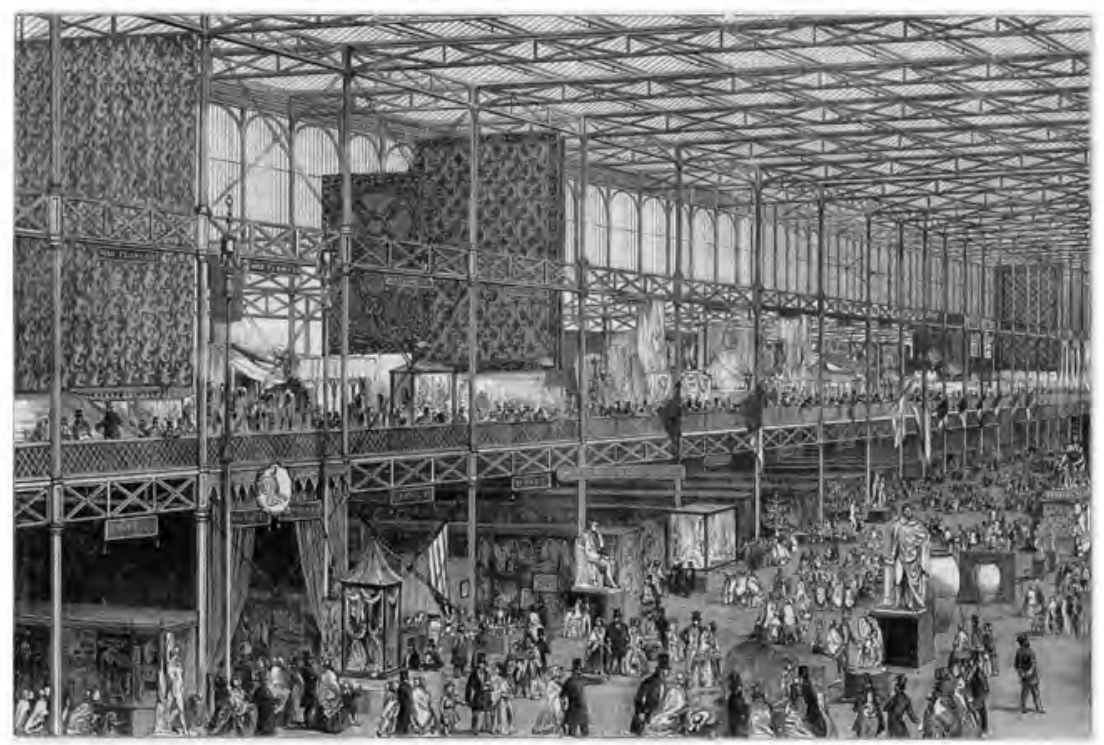

Figure 4.2 A view of the east nave of the Crystal Palace, showing the Persian booth in the bottom left corner.

Source: Grand panorama of the Great Exhibition of all nations 1851 from The Illustrated London News. 
natural paradise, now realized through architecture. The significance of this modern edifice for Farrokh-Khan was profoundly shaped by his vision of Farangestan as a garden of heavenly delights.

Adding to the heavenly qualities of Farangestan were the seemingly miraculous effects that botanical gardens offered. All four travelers wrote about this Farangi wonderment enthusiastically; the controlled environment of the botanical greenhouse was a great sensation but not a totally unexpected one. These spaces wherein a multitude of flowers and fruits from across the globe were cultivated together, without regard to season, ${ }^{50}$ had a dreamlike and magical quality that was not unfamiliar to the travelers. They gradually recognized how it resembled the Garden of Eden in Islamic religious texts. In all four memoirs, the association of Farangi parks and gardens to heavens is extremely common. ${ }^{51}$ The words behesht, rezvan, and jenan, all meaning heaven(s), are repeated more than fifty times in Rezaqoli's memoir, demonstrating how the ideal of a garden influenced his perception of spaces. ${ }^{52}$ Rezaqoli's application of such phrases is so recurrent that at the beginning of the English translation of the book, Kayat feels obliged to explain, "as this phrase will be used often in the narrative, the translator begs to assure his readers that this is the highest mode and the strongest style of expressing beauty of faces, \&c." 53 The metaphor of heaven, which repeatedly shows up in all of the memoirs, is not exclusive to natural environments, but is also adopted to describe prosaic locales as roadways, town squares, residential buildings, theatres, palaces, and observatories. ${ }^{54}$ An example of such use of paradisiacal imagery can be seen in Rezaqoli's memoir, when he writes about attending performances at the London Opera House and Astley's Amphitheatre (see Plate 12). While these spaces contained no trace of garden-like greenery whatsoever, the comparison seems to have been triggered by the "barebreasted women with faces bright as the full moon" whom the prince encountered there. ${ }^{55}$ Comparing these women to the huris - the fairylike companions of devoted Muslims in heaven - Rezaqoli offers yet another evidence that justifies his heavenly rendering of Farangestan. The presence of apparently unfettered women in these public spaces strongly heightened Farangestan's heavenly effect. In some cases the travelers seem to exaggerate this aspect of public parks beyond all reason: Rezaqoli, for example, when describing Vauxhall Gardens in London (see Figure 3.1), suggests that in this idyllic locale men could flirt freely with any woman they desired, starting with one and, once satisfied, moving on to experience another. ${ }^{56}$ Farrokh-Khan's description of a carnival in Paris similarly paints a city-wide public orgy:

parties are held in all streets and neighborhoods, where men and women have utmost freedom. ... Any kind of talking, flirtation, and joking with women is tolerated. It is even fine to kiss any woman without previously knowing her. There is an utmost freedom in kissing. ${ }^{57}$ 
Abolhasan likewise provides the following description of London's Hyde Park:

We saw some 100,000 men and women parading themselves on foot and on horseback. Elsewhere pretty girls and handsome youths were admiring the gardens: although it was winter, the verdure of the park rivalled the Bagh-i Eram, the Garden of Eden." 58

Such exaggerations were by no means intended for a sinful portrayal of Europe - the travelers rather sought to portray an innocent combination of forbidden elements that intensified their heavenly rendition of Farangestan. "The outskirts of Damascus," as Rezaqoli suggests had all such elements: abundance of greenery, picturesque springs, divine music, red wine, and fine-looking women. To Rezaqoli,

[it] was like heaven. From each side, we saw colorful scenes, and from each corner, we heard harmonious chords. Twenty thousand men and women, with no hijab, were mingling cheerfully and flirting joyously. Fountains were gushing on all sides of this green paradise; sitting next to them were crystal cups full of red wine. ${ }^{59}$

The modern cities of Farangestan with their erotic combination of accessible women and public space find a paradisiacal yet earthly meaning to the travelers. "This city of beautiful buildings and beautiful women - this earthly paradise," as Abolhasan expressed his image of London, ${ }^{60}$ allowed for the reintroduction of a much older connotation of Farangestan as the land of the infidel. ${ }^{61}$ Rezaqoli, in a rather exceptional comment, asserts, "[Farangestan] truly has nothing less of heaven itself. How true is Hadith that says 'the world is the prison of the Believer, and the Paradise of the Infidel." "62 This distinction between the "material progress" and the "cultural aspects" of modernity, although rare in the studied memoirs, would find a more prevalent voice in later encounters with Europe, and would set the theoretical foundation for emulating the first and rejecting the latter. For the travelers studied here, this distinction is rare and the choice is clear - Rezaqoli's immediate reference to a poem by Hafez leaves little room for interpretation:

If the hope of the ascetic is for the maidens and palaces of Paradise For us the wine tavern is a palace and the beloved is a heavenly maiden $\left[\right.$ huri] ${ }^{63}$

\section{Reflecting a different sky}

The travelers' contemporary architecture in Iran is celebrated today for its harmonious coexistence with nature. ${ }^{64}$ Although back then sustainability 
was not conceptualized as we understand it today, the writers show sensitivity towards the built environment as it uses natural resources to efficiently respond to climatic challenges. In an urban scale, they remark on how open spaces and squares purify the city air. ${ }^{65}$ In the architectural level, they mention how houses are kept cool during summer and how moisture is controlled in multistory apartments. ${ }^{66}$ Even details such as the often-shut doors of shops in London, which kept the buildings warm during winter, are noted in the memoirs. ${ }^{67}$ Architectural innovations in the use of natural resources were similarly detailed with great interest. Rezaqoli for example credits "architectural design" for rainwater harvesting in Gibraltar. ${ }^{68}$

But despite the travelers' interest in the environment both as a natural resource and as a source of pleasure, they seem less interested in visual connections to the exterior environment. Discussions of views, as framed through architectural elements, are unexpectedly rare in the diaries. ${ }^{69}$ Even the European companions of the travelers noted their indifference towards views; Fraser for example seemed rather annoyed by Abolhasan's negligence towards the view that his apartment in Üsküdar, Ottoman Empire, provided..$^{70}$ However rare, the travelers' mentions of views show a consistent pattern: their interest in views was greatly intrigued when some sort of water feature such as - fountains, rivers, and oceans - was visible from Farangi buildings. ${ }^{71}$ Abolhasan, for example, admired how "all houses [in Galata, Ottoman Empire] looked upon the sea," how the balcony of Gibraltar's officials was "faced towards the oceans," and how a gallery in London overlooked the river. ${ }^{72}$

This interest in the visual presence of water in architecture may be triggered by the Persian buildings that the travelers had experienced. The delicately controlled treatment of water is commonly held as a central and essential feature of Persian architecture. This perception was greatly shared by the travelers, who thought of centrally located fountains as an Iranian tradition of architecture. ${ }^{73}$ In Iran, water is traditionally provided to households through hundreds of miles of underground irrigation canals, known as qanats. ${ }^{74}$ After being collected, this precious water harnessed with great effort - rests in pools carefully positioned at the center of homes, to be used for private gardens, to increase the interior courtyard's humidity, and to reflectively mirror the nearby greenery and the sky (see Plate 11).

The travelers expected to see a similar veneration of water in Farangi architecture. Rezaqoli's expectation was met, as on his way to England he stopped at Gibraltar, where he saw how

the houses are designed in a fashion so they collect the winter rain from the mountain and the desert. All this water is distributed among houses not a single drop is wasted. Throughout the whole year, they can drink fresh rain water. ${ }^{75}$ 
But in contrast to what they expected, the travelers were mostly struck by the apparent carelessness with which Europeans were able to treat this valuable resource. Their reaction is perhaps best summed up by Abolhasan's astonished exclamation at encountering a European fountain: "a statue of a boy pissing provided the water!" 76

While the architecturally situated pools of Farangestan seem to have been somewhat beneath the travelers' expectations, ${ }^{77}$ the broader streams of water within public spaces and throughout the landscape appeared heavenly. The mixture of gardens, trees, and fountains that they encountered perhaps brought to mind the recurring Quranic description of paradise: Jannat tajri min tabtiha al-anhar (gardens underneath which rivers flow). This combination appears in Abolhasan's enthusiastic description of "the heavenly fields" of London's parks: "stream of running water and elegant avenues, lined with rows of stately trees which seem to touch the sky." 78

Contrary to the impression one may get from relying solely on the travelers' diaries, their appreciation of natural and built fountains, as noted by their European companions, does not fade during their journey. Fraser's account, for example, describes (perhaps somewhat sarcastically) that at a countryside near Liege, Belgium, Rezaqoli and his brothers would stop "to babble at every little water course and spring by the roadside." 79 Trying to explain the princes' attraction towards fountains, Fraser makes an argument that, regardless of its depreciating tone, confirms the archetypal role of Persian gardens: "We took one or two excursions to a country-house near town [Bucharest] ... to which they took a fancy, because it had a fountain of good water, and resembled somewhat their own disorderly Persian gardens." 80

\section{The kingly palace}

Traditional Persian architecture is known for its a relative lack of functional spatial divisions, at least compared to European standards. In other words, there is a greater sense of "affordance" in the use of various rooms and buildings, and there are fewer spaces that are set aside for single purposes such as dining, sleeping, or leisure. ${ }^{81}$ While some Orientalist commentators have probably exaggerated this aspect of the premodern Persian environment, it is apparent that the travelers are fascinated by the strict functional division of space that they encounter in Europe and that they consider it a novelty. They often express a certain amazement that in Farangestan an entire room might be set aside for no other purpose than housing children or eating meals. This form of spatial division struck the travelers, predictably, as being luxurious and utopian, and the functional division of rooms became an important aspect of their portrayal of rational order. Abolhasan, for example, indicates that the Crown Inn (where he lodged at Portsmouth) is like a "kingly palace" in that it has separate sleeping areas for everyone. ${ }^{82}$ 


\section{Imagining the modern}

Rezaqoli is similarly amazed that his hotel in Exeter has separate rooms for various functions:

It is comprised of many apartments, and each royally furnished house has a separate room for bathing and a distinct place for dining. Every traveler is shown to a room for himself, attended by a servant. I was struck with amazement! $!^{83}$

Even more astonishing to the travelers is that separate accommodations are available to their lowest attendants and to members of the general public. ${ }^{84}$ The luxurious image of Farangi buildings gets stronger when the travelers see rooms dedicated to services that in Iran were provided through public facilities. All of the travelers are particularly fascinated to see that regular houses and hotels in Farangestan have a separate room for bathing, a "service" that, in Iran, was provided publicly through hammams (bathhouses). When attending parties at noble estates they are exposed to even more luxurious rooms, including private theaters, galleries, dancing rooms, cloakrooms, and libraries. ${ }^{85}$

While at first baffled by the novelty of these designated spaces, the travelers quickly begin to adopt the relevant terminology. Mentions of functional divisions in Farangi architecture increase in the travelers' notes as their journey develops. In their attempt to introduce the topic, some even transliterate the foreign concepts for functionally specific spaces into Persian. ${ }^{86}$ Such attempts show the necessity that the travelers felt in introducing functional division of space as a tool to understand and evaluate Farangi architecture. Mirza Saleh in particular takes pains to describe the layout of London apartments, including the specific use of each room and its horizontal and vertical position within the building. He repeatedly emphasizes the novelty of single-purpose spaces:

The first level is dedicated to storage and a space for the kitchen. . . . All cooking devices are provided in the kitchen. The second floor has a room where lunch and dinner are served. They don't often use that room, only when it is time to have lunch or dinner. The third floor is the living space for the residents. .. . The library and the bedrooms, as well as children's and maids' rooms are located in the fourth and fifth floor. The sixth and occasionally the seventh floor is where the servants reside. Each household has a specific room for sleeping. Everything, whether sleeping, sitting, or cooking, has a separate room. . . . Every person has a separate sleeping room. ${ }^{87}$

While the initial reaction of the travelers suggests that some found the designation of entire rooms to certain functions somewhat excessive and even unnecessary, ${ }^{88}$ they gradually appreciated the spatial organization of complex functions through design. In his visit to the Foreign 
Office, Rezaqoli discusses how the architectural division of offices and departments can facilitate the management of complex functions. ${ }^{89}$ Farrokh-Khan similarly takes careful note of how government buildings are organized into rooms for specific civil and administrative purposes. ${ }^{90}$

The examples discussed in this chapter show how the travelers' interest in architectural functions extends far beyond residential typologies to encompass places of business and government facilities. This interest in the spatial manifestations of functions receives a considerably greater attention by the travelers when applied to urban layouts. Some like Mirza Saleh use urban functions as a system to categorize their descriptions of Farangestan. ${ }^{91}$ By the end of their respective journeys, each of the travelers had prepared a detailed list of Farangi typologies that could potentially be used as a model for urban development. Abolhasan's list, for example, begins near the start of his journey with schools, mosques, churches, monasteries, caravanserais, customs offices, and synagogues, and then expands during his travels to also include houses of parliament, houses of justice, banks, castles, hotels, museums, and libraries, among others. ${ }^{92}$

Farrokh-Khan's categorization of Farangi spaces is particularly interesting, due to the influence of this traveler's administrative position and his apparent concern for replicating European patterns in Iran. Unlike the other travelers, he does not seem particularly confused by the spatial organization of Farangi cities upon his first arrival. In Naples, the second city that he visits, his urban typology already includes all of the different kinds of buildings that he will note during the remainder of his trip:

A big city, a fine port, and perfect buildings, four to five stories, with wide and straight streets paved with stone, neat and clean. Magnificent buildings of different types such as hotels, schools, fine old churches, hospitals, extremely clean cafés, and a theater. ${ }^{93}$

It seems likely that Farrokh-Khan's categorization of Farangi buildings was strongly influenced by his reading of earlier travel accounts. Chronologically, his journey to Europe is the last of the four travelers studied here, occurring roughly forty years after Abolhasan and Mirza Saleh, and twenty years after Rezaqoli. By listing his full urban typology almost immediately after landing, it is as though Farrokh-Khan's functional division of Farangi space emerges straight out of his literary imagination, providing tropes that he can happily check off one by one. These categorizations of modern urban space, to the extent that they had become firmly established in the Persian imagination, were eventually incorporated into the organization of municipal government in Iran. This can be seen in the 1907 law known as Ghanun-e Baladiyeh, which included detailed lists of new types of buildings that Iranian municipalities were obligated to construct. ${ }^{94}$ 


\section{The bridal chamber}

Concepts of purity, cleanliness, and order are central to the travelers' vision of the Farangi ideal. While sailing towards Europe, Abolhasan had already come to the conclusion that, "the people of Farangestan make great effort to keep their appearance clean." ${ }^{95}$ Abolhasan returns to this theme continuously, emphasizing for example that the people of England are "unparalleled in cleanliness; they change their clothes three times a day, and wash their houses once every day." ${ }^{66}$ The travelers' obsession with manifestations of cleanness is similarly sought in architecture. Abolhasan's first impression when visiting the residence of the Prince of Wales was its "utmost pakizegi [cleanness]." $" 97$ The same adjective is used to describe the rooms and furniture of Christopher Wren's Naval Hospital and the British prime minister's residence, in Elm Grove. ${ }^{98}$ Farrokh-Khan, however, provides perhaps the most meaningful metaphor in his description of a railway passenger car, when he writes that "it was a thousand times neater and more organized than a bridal chamber." 99 The analogy of the pristine bridal chamber once again brings into play the eroticization of Farangi spaces, but it also rests on a profound concern for physical cleanliness and health.

The scholar Mohamad Tavakoli-Targhi has pointed out that everyday modernity in Iran started with efforts toward combating contagious diseases. "The early foundations of Iranian modernity," as Tavakoli-Targhi suggests, "were laid on state-initiated sanitary projects, such as paving roads, building public toilets, sweeping streets, collecting garbage, and moving cemeteries, slaughter houses, and tanning houses out of the urban living quarters." 100 Starting around 1850, the Iranian government began implementing a robust effort to keep cities clean by applying basic zoning measures and improving municipal services, ${ }^{101}$ all of which was based on the assumption that diseases such as cholera were caused by "city filth." 102

This same imperative can be seen in the travelers' memoirs, as their utopian ideal of cleanliness was closely tied to an aspiration toward order, including rationalized social order. For Mirza Saleh, cleanliness - although substantially important - was clearly subordinate to the general theme of following some kind of higher order. After providing a detailed and fairly objective description of St. Petersburg, he communicates his impression by saying, "truly, I have never seen a city so good, pleasant, clean, and organized in all my life." ${ }^{103}$ In their memoirs the travelers invoke an impressively nuanced set of signifiers for these concepts, words that were often used in complementary and interconnected ways. Of all the travelers, Farrokh-Khan is perhaps the most strongly taken with these ideas, repeatedly bringing to bear terms such as pak, monaqqah, and pakizeh (all meaning cleanliness) and pirasteh, arasteh, ba-nezam, ba-mizan, and ba-tartib (all suggesting order). Abolhasan uses a similar vocabulary, focusing on nazm, tartib, saman, entezam, and enzebat (all meaning order). The travelers sought these ideals everywhere in Farangestan, and throughout their journeys they rarely 
lost interest in the topic. ${ }^{104}$ When reading the memoirs, it often seems as though their writers feel an obligation to mention every single instance of cleanliness and order that they encounter in Europe, whether related to residential apartments, military equipment, gardens, the seating arrangements in churches, the lines of children at an orphanage, merchandise displays at a shop, or even the orderly bundles of hay in a stable. ${ }^{105}$

The travelers' appreciation of cleanliness and order has a utilitarian motive, in that they view these virtues as leading to greater overall social efficiency and health. ${ }^{106}$ However, this vision also has an aesthetic dimension that at times spills over into deep enchantment and even erotic longing. The pleasure that the travelers feel when viewing intelligently planned, rigorously regulated, and meticulously implemented order finds an additional aesthetic dimension in Farangestan - one that Siegfried Kracauer calls "mass ornament." ${ }^{107}$ Many of the travelers, even though they are often unable to comprehend the plots of the operas that they visit, find themselves enamored with the regularity on display there. Rezaqoli remarks in this context, "what women! what dresses they have, and what waists! what bosoms! and all alike too - all as if they had been cast in one mold! And how their steps all go together! Wonderful indeed! this is Behisht (Paradise)." 108 Similarly, at a military drill, the synchronized motion of de-individualized bodies that appeared as an assemblage of moving geometries caught the attention of Rezaqoli, who as Fraser reports was astonished by the "admirably calculated" performance of fifty thousand troops. ${ }^{109}$ In a strangely similar fashion, the Persians express delight at the visual aesthetics of musical ensembles, focusing more strongly on the systematic orchestration of the spectacles than on their actual content. Rezaqoli's brother Vali finds the ability of "one hundred musicians to strike the same note all at once ... more surprising than the music they make." ${ }^{110}$ This appreciation of systematic order over innovative content often governed how the travelers perceived and evaluated Farangi progress. The regulatory order of Farangi institutions, for example, fascinated the travelers more than their specific purpose. What struck Rezaqoli and his brothers at Bethlem Penitentiary was its "remarkable cleanness and good order," not the details of the establishment, as his European companion Fraser expected. ${ }^{111}$ Similarly, when Abolhasan's European companion James Morier points out some of the modern features of Istanbul, the ambassador replies dismissively, "What is the use of such country, if it be without order?" 112

The desire for order finds expression in the architectural realm most directly through discussions of spatial regulation and planning. Spatial patterns of order were often first witnessed in the urban design of streets. The travelers' early impression of city streets as "wide, paved, and straight," as detailed at the beginning of this chapter, is an important part of this outlook. As they got more exposure to Farangi streets, the travelers were able to identify additional patterns of spatial order, whether it be the symmetry of intersecting paths in a garden, the modular pattern of protective balustrades 
along a roadway, the orderly positioning of street lamps and signs, or the matching designs of row houses along a street. ${ }^{113}$ While associating urban regulations with the all-encompassing Farangi order, Mirza Saleh provides a rather detailed observation of London's urban design. "Most streets in London," Mirza Saleh explains,

are built with order: houses are symmetrical and their walls share a similar brickwork. The name of the street and district is scripted at its entrance point and on the door of every house, its number is written in English. The streets are wide enough to accommodate the transportation of four coaches. Both sides are paved for pedestrians and the middle part is dedicated to horses, wagons, and coaches. On each side of the street, at six to ten zar' intervals, a lantern is fixed above the doors that burns all night long. ${ }^{114}$

Farangi urban codes and standards - especially in residential typologies also received attention from the travelers, who were actively looking for spatial patterns. Highly regulated urban districts were often pointed out by the travelers for their function, height limits, signage regulations, fenestration codes, exterior wall materials, and land use. ${ }^{115}$ At Bath, for example, Rezaqoli feels the guiding presence of such regulations. "The houses," he suggests,

are 100 feet in height; their walls are glazed and look like glass, and all of them are straight to a hair. [The doors on each side of the street are symmetrically located in front of each other.] The names of the inhabitants are either written on the door of the house, or else the doors are numbered. Every street has its name. ${ }^{116}$

The rationale behind such codes and regulations is usually taken for granted by the travelers. By assuming a justified reason for each regulation, they emphasize the presence of this order over its underlying rationale. Yet, some travelers show more curiosity to learn why such construction codes were institutionalized. Mirza Saleh, for example, explains that after multiple earthquakes the height limits in Istanbul were regulated and monitored to facilitate disaster management. ${ }^{117}$ The building material codes in St. Petersburg and London, as Mirza Saleh writes, were likewise attempts to limit the spread of fire. ${ }^{118}$ Abolhasan observes that street-side balustrades are regulated to prevent horse riders from crossing onto the pedestrian pavement. ${ }^{119}$ The street layouts of Bath, as Rezaqoli explains, were regulated to prevent traffic congestion. ${ }^{120}$ Rezaqoli also shows a general understanding of zoning when he explains that all industry and factories in London are located outside of the city. ${ }^{121}$

Everything about Farangestan appeared regulated and everyone seemed to submit to this transcendental order. ${ }^{122}$ "Every man," Abolhasan suggests, 
"whether of high or low estate, wears a watch in his waistcoat pocket; and everything he does ... is regulated by time." ${ }^{123}$ Urban and architectural space in Farangestan were likewise subject to some kind of underlying order - one that Abolhasan calls "geometric thinking and design patterns." 24 Such design patterns were so expected by the travelers that their absence raised more curiosity than their presence. ${ }^{125}$ Occasionally, the travelers' imagination about the regulatory order of Farangi space surpasses reality. ${ }^{126}$ The order of Farangi space finds a dominant voice in the memoirs; nevertheless, the institutional foundations that enact and enforce spatial regulations were rather neglected. Farrokh-Khan, who attended a city council session during his stay in London, is silent about the institution and its purpose. Abolhasan had found the municipality of London to be a useless office that needed to be abolished. ${ }^{127}$ The travelers generally felt that the regulatory order of Farangi space was unrelated to Farangi forms and institutions of spatial governance. Disconnecting Farangestan's regulatory order from its institutional foundations allowed any form of governance, and particularly Iran's monarchal regime, to mechanically impose similar codes and regulations on space.

Farrokh-Khan - who like the other travelers believed that, "All that is built [in Farangestan], such as villages, gardens, and houses, follows a certain size and order" - explains that this order is, "because in this nation, no one can build a structure arbitrarily unless approved by the state and compatible with the plan of the state architects. This is why all the villages, cities, gardens, farms, and roads have an architectural design." 128 Farrokh-Khan had come to such conclusion about the role of state-mandated regulations on just his second day in Europe, while traveling from Lyon to Paris. The travelers, who typically shared Farrokh-Khan's government background, actively sought evidence that would endorse legitimization of state power in the built environment. Later in his journey, Farrokh-Khan had the opportunity to engage in multiple discussions with Georges-Eugène Haussmann, the prefect who oversaw an array of extravagant urban interventions in Paris. ${ }^{129}$ This experience doubtlessly gave the traveler an intimate opportunity to learn about the top-down processes of urban design and management in Farangestan. When reporting on one of Napoleon III's speeches, Farrokh-Khan again confirms his appreciation for large-scale urban projects conducted through state authority, including the renovation of hospitals in Vincennes, the development plan of Lyon, various street designs, and the restoration of historic cathedrals. ${ }^{130}$ Farrokh-Khan's interest in regulating the built environment through centralized authority would later become important during his oversight of urban development in Tehran, after he was appointed as the Iranian minister of the interior in 1859.

In contrast to this dominant outlook towards Farangi order, Mirza Saleh shows interest in the gradual and participatory processes of environmental design. He reflects on the role of city councils and municipalities, ${ }^{131}$ and at the same time emphasizes how long-term urban projects are an outcome of 
gradual change. Mirza Saleh, for example, mentions the material codes in St. Petersburg, which eventually changed the wooden structure of buildings: "gradually all walls were constructed from brick and stone." $132 \mathrm{He}$ similarly touches upon the issue of mutual responsibilities between the public nation and the state, through discussing the more participatory means of urban renewal. Again in St. Petersburg, Mirza Saleh notices that every property owner is responsible for paving their part of the street that is adjacent to the land. With this regulation, Mirza Saleh suggests, "all the streets are now paved with stone." 133 Unlike the other travelers, Mirza Saleh does not attribute larger urban projects to the power, wealth, and leadership of Farangestan's wise and caring monarchs. He rather emphasizes the collaborative system through which the public directly benefits from projects that it had collectively funded. While describing the construction process of public roads in England, Mirza Saleh writes:

A person is appointed at five to ten mile intervals to collect money from the people who pass through. People riding on horses pay three pennies while coaches pay six pennies or more. The collected money is spent on further road construction. ${ }^{134}$

\section{The nightless city}

By learning more about Farangi institutions in charge of urban services and management, the travelers' conception about the source of Farangestan's orderly and clean appearance become more complicated. This cleanness is no longer simply attributed to the individual habits of Farangi people, ${ }^{135}$ it is also a result of a publicly provided urban services. Several of the travelers dwell on the manner in which urban spaces were constantly monitored, swept, and repaired. ${ }^{136}$ At his first stop in England, Rezaqoli outlines a detailed report on the street cleaning system of Bath:

we saw a horse drawing a sort of carriage on which there was a large wooden barrel, which might contain about 2000 manns (a Persian weight) of water. Attached to this barrel there was a hollow tube pierced with small holes, through which the water pours out, and by this means all the street was sprinkled with water in a second, which a hundred carriers of water could not do in five hours. After this, another cart came and swept all the dirt and carried it away. In a minute all the street became as clean as looking-glass. ${ }^{137}$

Many other urban services similarly took part in the orderly appearance of Farangi cities. Abolhasan, for example, mentions how professional gardeners were assigned to each square in order to "preserve the paths, trim the trees, maintain the hedges, and plant the flowers." 138 In their discussion of Farangi hygiene, some of the travelers even take note of the less-visible 
urban infrastructures of Farangi cities. ${ }^{139}$ To dispose of sewage, Mirza Saleh explains:

in every street, they have dug a big path under the ground, its width is approximately two zar'. Every street has multiple slopes which direct rain water and sewage. In every house the waste water is directed to the path where it heads towards the Thames and eventually to the sea. ${ }^{140}$

Farangi urban services and infrastructure became a source of great wonder to the travelers, often equal to many of its technological achievements; ${ }^{141}$ yet, they were seldom regarded as a means of social justice. Equal access to basic urban infrastructure and services was indirectly touched upon, especially in the travelers' discussion of Farangi water distribution systems. "Every Kitchen in England," Mirza Saleh observes, "has a faucet that constantly brings water from outside." 142 "In every English house," Rezaqoli similarly explains,

multiple faucets exist that, once opened, dispense as much water as needed. . . . They have taken measures to elevate the water from beneath, so that even in the upper stories of every house one can have easy access to it. ${ }^{143}$

Rezaqoli continues his observation to discuss another urban service and its hidden infrastructure:

Since most of the houses are built of wood, fire is frequent. If this occurs, they can remove a stone on the wall and attach a leather pipe to it that can shoot water three hundred zar' into the air. In less than ten minutes the whole house is full of water and the fire is out. Beneath all of the buildings in London rests such a pipe. ${ }^{144}$

Abolhasan also touches on the subject of firefighting, but his choice of the word minaret to denote fire detecting towers renders an image that was familiar to his Persian readers. ${ }^{145}$

In similar passages, the travelers express a fascination for the details of European infrastructure of all kinds, including garbage disposal, rain collection, thermal efficiency, road signs, and even public restrooms, among others. ${ }^{146}$ But perhaps the Farangi urban infrastructure that amazed the travelers most was natural gas processing and distribution for streetlights. ${ }^{147}$ The services related to public lighting are best described in Abolhasan's memoir:

Above the entrance to each house, large round glass lanterns are suspended from iron hooks. One man is responsible for cleaning the glass of the lamps; another looks after the wick and the oil; and at sunset a third comes with a ladder and sparking torch. And in the twinkling of an eye, all lamps are lit. ${ }^{148}$ 
While the travelers would have been familiar with strong night-time illumination in the courts of Persian kings, ${ }^{149}$ the prevalence of oil and gas lanterns throughout the entirety of the Farangi city struck them as a marvelous spectacle. The travelers show a consistent pattern of amazement and wonder on their first encounters with Farangi public lighting. ${ }^{150}$ Some, like Rezaqoli, were so "overcome with astonishment" that they "scarcely knew in what direction to bestow [their] attention." 151 The massive coverage of artificial lighting across Farangi cities is so astonishing that Farrokh-Khan doubts his ability to communicate what he has observed through language:

Seeing Paris at night, with the abundance of orderly rows of lantern lights along the streets and in the buildings and shops - even if I try to exaggerate it ... [my words] will not be equal to even one out of the thousands of lights. ${ }^{152}$

Likewise, Abolhasan remarks in various passages about the splendid vision of the Farangi city at night, repeatedly using the phrase "thousands upon thousands" to describe the numerous sources of illumination. ${ }^{153}$ Farangi streets with the multitude of their light sources appeared so bright that the travelers would constantly compare it to daylight. "The abundance of lights and fixtures in roads and cities," Rezaqoli asserts, "made them bright as day. No sign of darkness did we see. Looking over the street, the houses were lit and their reflection through the glass windows made the paths bright as daytime." 154

The prevalent comparison with daylight injected a miraculous enchantment to the travelers' descriptions. In this process, the travelers' early impressions of Farangi lighting systems greatly contributed to such magical renderings. Before every box in an opera house, Rezaqoli writes,

there are forty chandeliers of cut glass, each has forty lights; there are also lights in every part of this house. The forty chandeliers of cut glass, each containing forty lights, and each light of five branches, as well as the other lights, have one pipe which, by touching an instrument, all the thousands of lights suddenly become dim, so that you scarcely see anything; and by moving the instrument differently, they as suddenly give a powerful light. ${ }^{155}$

Interestingly, Rezaqoli had not yet seen any of what he so elaborately explained. He was rather voicing what his brother Vali reported from a short trip to London. Once Rezaqoli gets to learn more about Farangi public lighting, such wondrous descriptions decrease, ${ }^{156}$ giving room for more technical discussion about gas infrastructure. The light posts along the road to London, as Rezaqoli explains,

[burn] all night long. This light is not of oil, or any other liquid, but the extraordinary production which they call gas. ... This, which is 
the spirit of coal, is conducted through pipes, in the same way to every place. Thus the whole empire at night is as brilliant as day-time. ${ }^{157}$

Most diaries show a similar pattern, in which the author starts by dramatizing Farangi city light early in the writing and later shows more appreciation for its technology. Farrokh-Khan likewise categorizes streetlights among Farangestan technological achievements - next to the telegraph, rail transport, and steam engine - yet he tries to maintain its mythical charm. The technology of city lights Farrokh-Khan declares to be a miracle possible only with the wisdom, wealth, and power of King Solomon, continuing on to say:

God has blessed the kings of Farangestan with miraculous powers. . . . One example is the gas light, which moves fire like water and reflects it on the sky. ... Thousands and thousands of lanterns are lit in the city, which make the earth glow like a sky full of stars. These are signs of God's power, now granted to man. ${ }^{158}$

As the memoirs progress, the travelers often turn their attention towards the familiar yet spectacular light displays and fireworks. The travelers were particularly amazed by how the more ceremonial fireworks were not exclusive to the eyes of the nobility. Abolhasan for example provides a detailed description of the public fireworks held in Vauxhall Gardens (see Figure 3.1). There, he emphasizes the aesthetic appeal of the lighting from colored lanterns by comparing it with Persian enamel-work. ${ }^{159}$ Such metaphoric comparisons are frequent in the diaries. Since the contemporary Persian audience of the memoirs did not share a similar experience to what the travelers beheld in the illuminated cities of Farangestan, it was common among the writers to draw on metaphoric signifiers and Islamic associations to convey their sense of wonder. Abolhasan elsewhere suggests that the lamp-lit Farangi cities "are brighter than sunny days" and "dazzle the eyes of the stars." 160 City lights are frequently compared to "moons" and "stars," and "chains of fire" in Farrokh-Khan's writing. ${ }^{161}$ These elements derived from Persian literature likely produced an image in the readers' minds that drew more strongly from an imaginative and poetic utopianism than from the actual prosaic realities of nineteenth-century Europe.

As is the case with garden spaces and parklands, the appreciation that light receives in the travel writings is in part due to its symbolic value in Persian poetry, Sufi spirituality, and Islamic ideology. Al-Nur, The Light, is one of God's names in Islam and also a name of a chapter in the Qur'an. Allah, according to this chapter,

Is the Light of the heavens and the earth.

The parable of His Light is as if there were a niche

And within it a Lamp, the Lamp enclosed in Glass

The Glass as though it were a brilliant Star 
Lit from a blessed Tree

An Olive, neither of the East nor of the West

Whose oil is well-nigh luminous, though fire scarce touched it Light upon Light. ${ }^{162}$

City lights were among the first modern urban services that were institutionalized in Iran's constitutional government. ${ }^{163}$ Yet, a more immediate consequence of this interest in city lights was reflected in the memoirs. Many important elements of modern public sphere, particularly the role of public space as a site for social interactions and urban life, may not have even been introduced in detail, if it was not for the travelers' fascination with streetlights. Describing the different light feature at Champs-Élysées, Farrokh-Khan indirectly introduces the nightlife of the street and how it was accommodated by numerous public activities and urban functions, such as cafés and theatres, ${ }^{164}$ all of which were novel to an audience that had a dramatically different conception of public space.

\section{Space that belongs to nobody}

Particular attention is merited for the relationship between the travelers' concepts of order and their views of personal liberty, popular sovereignty, and public space in Farangestan. At first glance, the writers appear to be both astonished and gladdened by the degree of personal freedom that they encounter in Europe. Perhaps a bit paradoxically, they attribute this expanded freedom to the very phenomena of domestic order and constitutional law that they perceive as regulating the minute activities of civic life. "Freedom in this land," according to Abolhasan, "is beyond imagination even the king himself cannot insult anyone if it is not permitted by the law." ${ }^{165}$ Rezaqoli likewise remarks, "In all the cities of England, wherever we visited, there is no guardianship and no sovereignty, because people act rationally and orderly. . . . Their land is all freedom and liberty." ${ }^{166}$ Mirza Saleh expresses a similar sentiment:

Who can even imagine that the Prince Regent, who is practically the King of the city and, except for lacking the crown, his deeds and commands have the same authority of the King's, has constructed a road in Oxford Street, and a craftsman, an impoverished person, who owns a shop in the middle of the street, is resisting all their attempts to construct the road through his shop? If hypothetically, the whole army gathers, they cannot force him to abandon his property. Funny enough, the Prince himself cannot threaten the person physically or financially. ${ }^{167}$

In all of these passages the concept of freedom is viewed as resulting from limits on power provided by constitutional order. The travelers do not generally recognize that the legal apparatus of the rationalized state could also become a means of oppression. When reading further it becomes clear that 
order stands as the primary value for the travelers, and that freedom takes second place should the two ever come into conflict. This outlook is particularly strong for those travelers with government backgrounds. Abolhasan, for example, was exposed to a situation in which a British populist reformer, Sir Francis Burdett, had come into conflict with the government and barricaded himself into his house along with a large mob of defenders. Abolhasan initially describes the situation with admiration for the government's restraint:

When I asked why the rioting had not yet been suppressed, they said that the councilors were still deliberating and that without a warrant from the Council, they could not remove the criminal from his house to the King's prison. I was utterly amazed! If such a situation had lasted for several days in one of Iran's cities, two thousand or more people would have been executed by now. I was even more perplexed by the length of time the Council was taking to order the criminal's arrest. I am recording these facts to demonstrate the freedom and benevolence enjoyed by the citizens of London. Because the Government is concerned that no innocent person should be molested, no one is arrested until his crime has been proven. ${ }^{168}$

Nonetheless, when pressed on the matter, Abolhasan reveals his personal judgment confirming the priority of order and security over freedom, and even over the rule of law: "Suppression of this chaos, I declared to the Lord, is much better than such level of freedom." 169 In another instance, Abolhasan again conveys an ambiguous attitude toward the relative social equality that he encounters in Farangestan:

My servants started a quarrel among themselves, and I was just about to punish them when Sir Gore Ouseley stopped me. He said that in this country the master does not have absolute power overs his servants even in the case of the King of England. Laws exist for the welfare and protection of all classes of people and are administered in the King's name. If a master locks up his servant, the servant may complain to a judge, and the judge may summon the master to pay a fine. On hearing this, I [jokingly?] begged him to forbid the English servants from divulging these matters to my own servants: it would make my work in this foreign land all the more difficult. ${ }^{170}$

In portraying social welfare laws as "foreign," Abolhasan takes a rather ambivalent attitude toward their value, and toward the extent that they should be seen as part of the Farangi ideal. The "regulated" freedom that the travelers admire, in this context, becomes a means to attain systematic order, without disturbing the class structure.

A similar ambivalent position toward equality is also expressed by the various travelers in relation to clothing and all manner of social norms. The 


\section{Imagining the modern}

travelers voice the utmost fascination upon learning that there are few formal distinctions of dress between European nobles, merchants, and craftsmen, and that at times even the King might go about in ordinary clothes. The objective tone with which Mirza Saleh touches the issue, when sharing his observation of Farangi outfits, conceals his probable approval: "there is no difference in outfits of the nobility, the merchants, and craftsmen in this land." ${ }^{171}$ Rezaqoli, as a person who did not tolerate any disrespect of his "high pretensions" and his "rank of birth," 172 also showed fascination with the idea that in Farangestan all people, even persons of rank, "are clad alike and there is no distinction in dress." ${ }^{173}$ While the responses of Mirza Saleh and Rezaqoli to this phenomenon are positive, Abolhasan expresses a distinct concern that the situation might lead to disrespect toward the class structure: "people may get the false impression that there is no difference between a driver and his master." ${ }^{174}$ Abolhasan disapprovingly explains that through such humble gestures of compassion with the inferior, the nobility exercised "more control over their ego." For Abolhasan, the ideal relationship with the lower classes was not one of equality, but out of sympathy. As he suggested in a letter to the London Morning Post, "the Ladies and Gentlemen this country, most high rank, high honour very rich (except two or three) [are] most good, very kind to inferior peoples." ${ }^{175}$ This sort of distanced "kindness" is endorsed by Abolhasan's frequent description of institutions that provided social services to the people he considered inferior, i.e. the poor, the elderly, the retired, the disabled, and the sick. ${ }^{176}$ The large building of the Magdalen House, dedicated to penitent prostitutes, Abolhasan emphasized, "[was] supported by the Government and public donations." ${ }^{177} \mathrm{He}$ similarly attributed the space and services provided at Greenwich Hospital and Chelsea Royal Hospital (both designed by Christopher Wren), to the kindness of the King. ${ }^{178}$ In his letter to the London Morning Post, Abolhasan writes:

I go to see Chelsea-all old men sit on grass, in shade of fine tree, fine river run by-beautiful place, plenty to eat, drink, good coat, everything good.... God he love the King very well for keeping up that charity. ... Soldiers fight much better because see their good king take care of old wounded fathers and little children.-Then I go to Greenwich-that too good place ... fine house-fine beds-all very good—this very good country. ${ }^{179}$

Public endowment of these excellent buildings was an act of charity of such magnitude that only great kings can afford. This charitable relationship with the masses, as implied by Abolhasan's take on British soldiers' willingness to make greater sacrifices, would in fact reinforce the class structure by encouraging greater loyalty and submission. Equality and thus democracy was not particularly appealing to Abolhasan, as can also be seen in his response upon learning that the mayor of London was an elected position that "did 
not require noble birth." He immediately scoffed at such a concept, stating that the "useless" office should be abolished, and warning his entourage to avoid mixing with "tradespeople." 180 Thus, his apparent approval for freedom under the rule of law seems to be grounded not in a desire for social equality but rather in a paternalistic outlook in which the imposition of order allows for greater charity and harmony among the social classes: "It is the rule that one should not overtake someone of higher rank; everyone knows his own place and respects the rank of others. The world would do well to emulate such politeness." 181

While sartorial integration of classes received considerable attention by the travelers, they showed less interest in recognizing a similar spatial pattern. If the travelers' attitude toward the democratization of urban space seems quite ambivalent, it may be in part because the concept of the public ownership of space was not well-developed in Iran at the time. The manner in which the travelers touch the subject shows how their conception of public space became more complicated during their travel. The travelers' first encounters with public spaces were characterized primarily by astonishment and curiosity. Mirza Saleh, for example, was utterly amazed to see (in his estimation) almost twenty thousand people enjoying themselves together in one "garden," in St. Petersburg. Yet, such stages for public gathering were often attributed to a charitable donation or a public service provided by the government. Mirza Saleh, for example, continues to describe "the House of the People" at St. Petersburg as "one of Peter the Great's ideas to encourage people to gather and mingle with each other. He built a place where people could gather, read books, play chess, and engage in various forms of amusement activities. Every day, people spend five hours at the House of the People." 182 Unlike the idea of public space, endowment of space to a charitable cause was a familiar concept to the Iranian travelers. In their initial descriptions of public space, most travelers seek a comparison in Islamic law by describing such places as "a waqf [religious endowment] to the public." ${ }^{183}$ Abolhasan for example explains that the Kensington Gardens in London is waqf-e 'am (an endowment to the public), "which means that young and old, men and women alike, can use it as a place for excursions." ${ }^{184}$ FarrokhKhan adopts another form of religious comparison, explaining how the streets and neighborhoods in Paris become sites to public festivities, similar to a continuous Eyd (an Iranian and Islamic feast). ${ }^{185}$

Over time, and as the travelers were further exposed to European urban culture, they gradually redefined their understanding of public sphere. The words 'am and 'omum (the public), which appear rather late in the memoirs, are often adopted in relation to space. Mirza Saleh, for example, informs his audience that the English word "park" designates a space that is similar to a bagh (garden) but is intended for use by the 'am (the public). ${ }^{186}$ FarrokhKhan similarly exploits the unfamiliar concept of "park" to discuss how the entire nation benefits from it as a place of leisure as well as a site for public ceremonies. ${ }^{187}$ Later, he extends his concept of public space to include 
Farangi streets. Boulevard des Italiens, Farrokh-Khan declares, "is a public tafarrojgah [place for recreation] . . . even Parisians are charmed by its nightlife. Many theaters, cafés, and hotels are located here." ${ }^{188}$ Rezaqoli initially describes parks as space "that belongs to nobody," but later changes his formulation to replace "nobody" with "everybody." By the end of his journey Rezaqoli has developed this interpretation so as to provide an astute formulation that grounds the concept of public space in political relationships. In Farangestan, he explains, "the state belongs to the public. Naturally, the public participation in government brings about strength and prosperity, because when everyone holds a share, no one will lose sight of their collective benefit." 189

The vision of people from all walks of life mingling openly and politely in well-ordered streets and parklands was easily incorporated into the utopian Farangi ideal, but the threat of equality produced by this chaotic mingling gave rise to a distinct set of social anxieties. Despite their fascination with the concept of public space, ${ }^{190}$ the travelers were careful to minimize its threat to social hierarchy. Abolhasan is the most cautious about the potential for mingling among the classes. He expresses this concern by seeking out reassuring limitations on Farangi public spaces. He is at pains to note that some areas of parks, exhibitions, panoramas, and concert halls have entrance fees and other regulations that prevent the "ordinary folk" from freely participating. ${ }^{191}$ When describing Portman Square, a popular gathering spot where he spent time on a daily basis, Abolhasan indicates that the space is surrounded by high iron fence and that it is only accessible to those who live nearby and hold keys. This, he says, is a common feature of public squares: "Each square belongs to the owners of the houses surrounding it, and only they are allowed to go in. On each side, there is an iron gate." 192 Apparently the free mingling of the classes was not as much a part of the Farangi ideal as was the mingling of the genders.

The ambivalent interest and social reservations that the travelers held about public spaces were generally reflected in subsequent municipal development in their homeland. In other words, the transformation of modern public space in Iran shows a trajectory similar to the travelers' gradual reconception of public sphere. The closest thing to a public park that existed in premodern Iran was when a wealthy owner of a garden would occasionally open the space as a courtesy to the community. An example is the Lala Garden in Yazd, which was famed for its flowers and fruits and allowed visitors during the weekends. ${ }^{193}$ Over time, some of these private gardens gained particular features and regular entertainments, similar to the functions that the travelers witnessed in Farangi parks. Sabat Garden in Yazd, for example, accumulated a collection of exotic wildlife, and came to function as a kind of limited public zoo. ${ }^{194}$ As the concept of public space gradually developed, some of these gardens were acquired by the state and designated as formal parks. However, this transformation occurred very cautiously, and did not get under way in earnest until Reza Shah's reign (r. 1924-1941). 
Beyond their admiration for orderly public parks and entertainments, the democratization of architectural space held little appeal for the travelers. In contrast, they seem to have internalized the spatial hierarchies that were predominant in the residential and religious buildings of premodern Iran. ${ }^{195}$ Their discussions of Farangi buildings exhibit a keen eye for identifying and tracking spatial ordering and hierarchies, which were still prevalent in Europe. Rezaqoli, for example, always demands a "suitable place" at the social gatherings he is invited to, and he expresses confusion and a concern for his dignity if he cannot identify the appropriately ranked spatial positions. ${ }^{196}$ Abolhasan likewise learns early in his trip that people at a European table are seated based on their rank. Throughout his journey he maintains a keen interest and observation of this pattern of distinction, as well as of ranked seating positions at the opera and in parliament. ${ }^{197}$ Such observations about spatial hierarchies were often confirmed by the travelers' European hosts, as a gesture of their respect towards their Persian guests. ${ }^{198}$

Some travelers even identified hidden patterns of vertical segregation of classes in Farangi buildings. Farrokh-Khan, for example, describes how different floors separated administrators, directors, workers, and servants in France's École Militaire (Military School). ${ }^{199}$ Associating verticality with social class, Mirza Saleh similarly explains how the upper levels of London's residential apartments were left for the servants. While the left-overs of space are assigned to the lower classes, the nobility claim the center. The King's room, as Mirza Saleh observes, is conveniently positioned in the center of the Winter Palace, which itself is located in the middle of St. Petersburg. ${ }^{200}$ In his description of the English Parliament in Westminster, Farrokh-Khan indicates both public order and stratification by associating centrality to power and relocating the public to the periphery. "It was a perfect and venerable building," Farrokh-Khan writes,

at the top was the shah-neshin [royal parlor] and in the middle of the shah-neshin was a seat for her highness the Queen, and the royal crown was suspended from above, and to the right of the Queen was a seat for her husband. And all around the room were parts for the public. ${ }^{201}$

This passage almost precisely mirrors the description that was given forty years earlier by Mirza Saleh when he visited the same location:

The room is a big and long square, as fine as it can be. ... On the top rests the King's couch and on the sides are seats for his appointees. ... The nobility of each state and the members of the House each sit in their own spot to discuss governmental affairs. ${ }^{202}$

Although these two travelers came from distinctly different socioeconomic backgrounds and were separated significantly in time, their attentiveness to the hierarchical space division in Westminster is nearly identical. Both of the 
accounts indicate an approval and affirmation of these social rankings as part of the idealized spatial ordering of Farangestan.

The varying building styles across nineteenth-century Europe shared a strong sense of symmetry with their Persian counterparts, which reinforced the travelers' correlation of centrality and hierarchy with a utopian image of progress. Yet, the reoccurring discussions of symmetry and centrality in the travel accounts reflect its appreciation by the travelers, ${ }^{203}$ who remain disproportionally silent when observing the similarly prevalent patterns of spatial integration. The fact that only one traveler admits that in Europe "no distinction exists between high and low spaces," while making sure to immediately comment on the bizarreness of this tradition, ${ }^{204}$ testifies that any conception of equality that threatens the established order of the class systems was not embraced by the travelers.

The same ambivalence towards concepts of freedom and equality vis-àvis order and law is later reflected in the Iranian constitutional movement, which came into power starting in 1906. As the name of the movement, Mashruteh (derived from the French constitutional "charter") suggests, while the movement led to the establishment of the first parliament in Iran, its priority, as many historians agree, was not democracy or individual rights, but rather the sovereignty of law and a more orderly form of government. ${ }^{205}$

\section{Touching the Milky Way}

BIGNESS is the ultimate architecture.

In chapter three, I described the Persian travelers' delight in reporting places and objects in Farangestan that hold some kind of superlative record, such as the tallest church spire, the biggest dockyard, or the palace with the most rooms. Among the various adjectives intended to covey the wonder of their journey, the ones relating to the magnitude of buildings are especially frequent. Sometimes these words occur all at once, such as when Rezaqoli uses the terms 'azim, rafi', and vasi' to describe Melk Abbey in Austria, referring respectively to its size, its height, and its area. ${ }^{207}$ This enthusiasm for architectural grandeur is applied by the travelers throughout their memoirs in relation to all kinds of construction, including churches, hospitals, castles, factories, hotels, offices, museums, bridges, squares, streets, porches, balconies, walls, domes, and arches. ${ }^{208}$ The travelers persistently mention the number of floors in multistory structures. ${ }^{209}$ To Abolhasan, the multistory hospitals, libraries, and administrative buildings were no less wondrous than a five-story ship that he visited at Portsmouth, Britain. ${ }^{210}$

As implied in their writings, the travelers associated building size with perfection, prosperity, and progress. Several of the travelers frequently juxtapose terms for largeness next to adjectives denoting perfection and beauty, as when Farrokh-Khan describes "perfect buildings, big churches 
and theatres, and two big squares," or when Abolhasan writes about London, "splendid houses line both sides of the street . . . I saw no humble dwellings, only fine houses of four stories." ${ }^{111}$ Abolhasan's other discussions about largeness suggest that he considered it to be an essential quality of healthy and wealthy construction. Astonished by the height of the Royal Hospital at Chelsea, Abolhasan expressed amazement that such a grand building would be constructed simply to house people who were ill. ${ }^{212}$ In a similar fashion, Abolhasan communicates his disappointment that a certain commercial building was "not very large," a feature that he dismissively attributes to the lower-class occupancy of the neighborhood. ${ }^{213}$ Largeness is a similarly a quality that indicates futuristic progress for the travelers. This temporal dimension of largeness is even extended to Farangi people, who as Abolhasan had observed, "build bigger and better than they did before." 214

Largeness, with all of its normative implications, was among the most expected qualities of Farangi buildings. ${ }^{215}$ It was constantly sought out by the travelers during their excursions, without losing its appeal. "The only remark I remember hearing from them," Fraser recalls, when discussing Rezaqoli and his brothers' visit to Cádiz, "was respecting the size and magnificence of the cathedral, which appeared to have made a considerable impression." ${ }^{216}$ In some occasions, the building size determines whether it is worth mentioning in the diary. ${ }^{217}$ Paradoxically, the repetition of adjectives denoting grandeur is carried out to such extent that they somewhat lose their intended impression. As a narrative technique, some travelers voiced the astonished reaction of other spectators, as a testimony to the magically gigantic dimensions of Farangi buildings. After writing about the largeness of Windsor Castle, Rezaqoli quotes the prince of Austria, whom he coincidentally met there: "you have seen nothing yet. I have been in this country for ten years during which I have frequented this garden with the Queen. Still, I have not seen one third of this castle." ${ }^{218}$ To re-mystify the grandeur of Farangi buildings, the traveler infused their descriptions with poetry and wonder. When writing about France's École Militaire, FarrokhKhan glorifies it as "an excellent and magnificent building, which sat like a mountain on the southern side of the square." 219 Similarly, when describing the Acropolis, he states, "I saw four magnificent buildings on a wide plane. Their height knocks off the hat of wisdom from one's head and the firmness of these sky-scraping buildings shakes one's wisdom." 220 The transcendental awe inspired by architectural grandeur at times merges seamlessly with the more romantic or paradisiacal visions inspired by other aspects of Farangestan. Abolhasan speaks of buildings that are "high enough to touch the Milky Way" and the experience of looking up at a "ceiling that reached the constellations." 221 In one passage Abolhasan invokes the celebrated verses of the Persian poet Sa'di (1210-1291) to glamorize the size of London's Brandenburgh House:

To heaven it says, as it towers so high, "You are the earth; it is I am the sky!"222 


\section{Constructing the magical}

Beyond straightforward attributions of physical size, Farangi buildings are notable in the travelers' estimation for the sturdiness and richness of their materiality, which stands as a symbol of strength. In the absence of a rich and nuanced lexicon to communicate spatial qualities, the precision with which some travelers identify and describe construction material renders a vivid image of their architectural experience. Rezaqoli, for example, provides a detailed description of the materials of the Academy Palace in Brussels:

All round the outside of the palace there is a balustrade of guilt iron bars three pikes long, and all its walls are built of beautiful marble. The furniture is of mosaic work, made of sandal wood and mahogany. ... The walls are constructed of marble of different colors, and between each stone is a line of gold. ... The interior walls are all covered with rich velvet, each room with a different color. The chairs about different parts of the palace are of gold and silver. ... Besides all this, there are numerous and most superb and unrivalled marble pillars. ${ }^{223}$

Despite such detailed observations, the writers seldom discuss material properties as they respond to climatic, economic, functional, and programmatic requirements. Resistance to water, according to Rezaqoli, made mortar the preferable material for the Thames tunnel. ${ }^{224}$ Fire resistance, as Mirza Saleh observed, justified the use of stone and bricks in St. Petersburg and London. The rationale for using iron as the primary material for a library room in Moscow, as Mirza Saleh explains, was protecting the books from fire. ${ }^{225}$ Aside from the few mentioned examples, the travelers generally ignore the practical considerations of building materials, especially when reflecting on Iran's domestic architecture. They associate Iran's premodern architecture with an inadequate scale of construction and perceived low-value materials such as mud, adobe, and brick, while focusing tenaciously on the contrast provided by the magnificent dimensions, rich quality, and stoutness of Farangi designs. Much like building heights, the materiality of Farangi buildings possessed an Otherly dimension that was conceived before the travels begun. Wood and glass were as much part of the preimagined Farangi building as pitched roofs. The houses in Tbilisi as Mirza Saleh suggests, "was from stone and bricks with a flat roof." But since Russia took over the previously Iranian territory, "all constructions are done with wood and glass."226

While the memoirs often note the presence of fine and celebrated materials such as gold, silver, and crystal, 227 the fundamental building blocks of Farangestan are stone, particularly granite. This pattern is confirmed throughout Abolhasan's diary, where the only mentioned material at different Farangi cities, like Malta, Gibraltar, Plymouth, and Bath, and different typologies, such as houses, hospitals, bridges, churches, and towers, is stone. ${ }^{228}$ The traveler's attraction to stone is primarily aesthetic. Mirza 
Saleh, who often avoids qualitative adjectives and normative statements, admires the "extreme beauty and elegance" that white stone construction has brought to Bath, England. ${ }^{229}$ Beauty and elegance are topics that typically inspire the travelers to exercise their poetic skills; however, the idealized context of Farangestan deflects the symbolic language of the diaries towards a magical rendition that could easily be taken literally. The travelers' playful word choices when describing materiality paint an image of Farangestan where stone acquires mystic qualities of liquidity, brightness, transparency, reflection, and softness. The "beautiful marble" applied to the walls of the Academy Palace, according to Rezaqoli, "was so polished that one could see the reflection of his own eye lashes." A stone pillar in the same building, according to Rezaqoli, "[was] wrought like glass."230 "Mirror-like marble" is a similar expression used repeatedly by Abolhasan. ${ }^{231}$ The exterior stone on houses in Bath, as Mirza Saleh suggests, "is so soft that, like wood, they can carve any shape out of it." ${ }^{232}$

Aside from its aesthetic quality, stone construction is admired by the travelers as a representation of firmness. ${ }^{233}$ Granite, which in classic Persian literature symbolizes firmness, is frequently mentioned in Rezaqoli's diary. ${ }^{234}$ Nearly all of such mentions are juxtaposed with terms indicating the principle of firmness, such as mohkam, mostahkam, estehkam, hesanat, and ghavi. ${ }^{235}$ Even descriptions of material such as glass, which is normally associated with fragility and delicacy, appear with connotations of firmness. Farrokh-Khan for example refers to the Crystal Palace as "mountain of glass," thereby rendering an image of largeness, solidity, strength, and firmness (see Figures 4.2 and 3.2). ${ }^{236}$ The normative significance of firmness is further emphasized by its frequent association with the word 'ali, meaning "perfect."237

The attention that architectural representations of firmness receives by the travelers is clearly influenced by the traumatic memory of the 1804-1813 Perso-Russian wars. The threat of another Russian war haunted the travelers, particularly the ones whose administrative background would require military awareness. This military outlook is evident in their writings about architecture, particularly discussions about firmness. The travelers' interest in architectural firmness is often provoked when visiting military typologies, such as forts, castles, and barricades. ${ }^{238}$ Château de Coucy in France was praised by Farrokh-Khan for its "extreme rigidity, stability, and strength." All of its surrounding 10-meter thick walls and its 40-meter high tower was made of stone, as Farrokh-Khan observes. ${ }^{239}$ Even the poetic language that the travelers use to glorify the firmness of Farangi buildings implies military considerations. Writing about the Acropolis, Farrokh-Khan suggests, "The buildings were crafted with huge rocks connected with iron joints. Much effort has been put on their strength and stability, where even imagination is unable to breach it." ${ }^{240}$ Rezaqoli likewise extols the defensive virtues of architectural firmness when describing the granite barricade surrounding Gibraltar as "so firm that not even an ant could pass through it." 241 


\section{Imagining the modern}

The military logic behind the travelers' fascination with architectural firmness similarly governs their interest in Farangestan's sociopolitical strength. The firmness of Farangi buildings is thus generalized to represent the strength of Farangi nations. "England," Abolhasan suggests, "has many virtues. Their houses are built with stone." 242 Referring to architectural firmness as the primary sign of Farangi progress is similarly reflected in Farrokh-Khan's diary. When summarizing his observations in Britain, Farrokh-Khan implies a direct association between the strength and durability of architectural construction and the advancement of Farangi nations:

Today, none of the European States have the great prosperity, rich market, and strong government as in England. All the buildings that I observed were like iron nails on stone. ${ }^{243} \ldots$ The buildings that they erect are built as strong as possible.... The difference between the British state and other states is that although all have developed many cities, the British state builds its cities only with stone and iron and without any masonry. But other states are stuck in the second and third level. ${ }^{244}$

The travelers' initial evaluation of architectural firmness was not based on an analysis of underlying structural principles, but rather on a visual sense of strength. The grander and heavier a building appeared, the more attention it received in the memoirs. The travelers' hyper-masculine appreciation for visual firmness and bigness is evident in their association of strength to large and heavy construction. The 10-meter thick walls of Château de Coucy and the 4-zar' thick barricades of Gibraltar, mentioned in FarrokhKhan and Rezaqoli's writings, similarly serve as a testimony to the buildings' strength. This visual evaluation of firmness even affects the language with which the travelers choose to describe their subjects. Abolhasan uses the somewhat incongruous term zakhim (literally, "thick") to suggest the solidity of a bridge's span. ${ }^{245}$

During their stay in Europe, however, the travelers begin to slightly reconsider their perception of firmness by showing attention towards more delicate and slender structures. Shifting away from the military typology, the travelers show particular fascination with a certain type of structure, through which they communicate their more technical understanding of strength. Nineteenth-century bridges are often noted by architectural historians for their role in inaugurating industrialized iron construction. Truss and suspension bridges become a great source of wonder to the travelers, this time not for appearing zakhim, but for their unconventional materiality, extraordinary spans, engineering ingenuity, architectural details, and even speed of construction. Mirza Saleh devotes an entire section of his memoir to the magnificence of London's bridges, providing detailed descriptions of Southwark Bridge, Black Friars Bridge, Westminster Bridge, and Vauxhall Bridge, among others. He places equal value on their materials, their length, the number of arches, 
and the span that each bridge covers. Amazed by the construction speed of Southwark Bridge, he states:

The construction of Southwark Bridge started when I arrived in London. Today it is finished and open to the public. The bridge is built from iron and has no more than three arches. The middle arch, which is said to be the biggest in the world, covers 70 zar'."246

Similar astonishment in relation to bridge construction is expressed by the other travelers as well. Rezaqoli remarks on an unnamed bridge over the Thames: "Not a tiny bit of stone, stucco, or wood is used in the bridge. It is all made from iron sheets and chains which are connected by iron joints." 247 Describing the Menai suspension bridge (see Plate 13), which Farrokh-Khan considers as one of the four greatest structures in the world, he writes at length about the process of forming these components: "They melt iron and mold it as boards, specific to the bridge, all in a single size and width. The boards are joined with iron pins, in a width of 6 meters and the length of 800 steps." 248 Abolhasan likewise speaks of iron bridges as large as Mount Damavand, erected by "masterful technicians" with "great ingenuity and measurement," with arches so high that entire ships can pass freely beneath them. ${ }^{249}$

Interestingly, while modern Farangi bridges attract the travelers' attention, their less solid, bulky, and massive appearance is not in total conflict with the travelers' masculine perception of firmness. In fact, they seem more baffled by heavy-appearing buildings that rely on delicate structures. In other words, the travelers' expectation for massive stone buildings erected upon heavy structures finds a more compelling dimension when the same architectural grandeur seems structure-less. Mirza Saleh exhibits the most open curiosity about inexplicable architectural edifices, ${ }^{250}$ particularly large vaulted ceilings that appear to soar without obvious means of support. "I saw a church called King's [College] Chapel," he writes. "The church has absolutely no columns." ${ }^{251}$ He noticed a similar phenomenon in Westminster Hall (Plate 14), where the central supporting columns that the traveler expected to see from his previous experiences of arched ceilings were simply not present. ${ }^{252}$ Westminster Hall, he explains, "Was a huge room. . . . Its length was 91 zar', its width was 25 zar', and its height was 31 zar'. The roof was built peculiarly, with no columns in the middle to hold it up." 253 Abolhasan likewise voices bafflement when describing a floating staircase at St. Paul's Cathedral (see Plates 3 and 9): "There was a cylindrical tower where stairs of stone were suspended without any support. The steps just hung from the wall." 254 Visiting the building for the second time, Abolhasan is still amazed that such gigantic and heavy construction elements seem structure-less, light, and floating: "The intellect is truly unable to comprehend how a dome so high and so wide was constructed without supporting pillars." 255 


\section{Imagining the modern}

While the travelers ascribe the allure of structurally exposed typologies (like truss bridges) to Farangestan's “technological ingenuity and measurement," they seem less curious to seek a rational explanation when massive solid buildings appear to be sustained without the expected structural support. The travelers - who often provide pages of detailed technical explanations about Farangi technological wonders, such as diving bells, balloons, gas lights, wool manufacturing, and even bridges - remain unexpectedly silent about construction technologies and structural details of Farangestan's majestic buildings. The ideals of strength and grandeur that the travelers projected onto Farangi construction, combined with the light floating effect that they later experienced, gave way to a kind of playful bemusement that satisfied the travelers' quest for wonderment.

\section{Aesthetics of rationality}

Reflecting on the progress that he saw in England, Farrokh-Khan makes an important conclusion that all the progress and esterahat (amenities) in England, including "its great prosperity, rich market, and strong government," are outcomes of people's "trust in rationality" in "secular affairs." To elaborate his concept of rationality, Farrokh-Khan provides an interesting example: "The nation and the state are free from seeking leisure, and their concentration is on development. Their ornaments are simple and they have good buildings and fine affairs" 256 Sitting next to adjectives such as "fine" and "good," "simplicity" finds a normative value that is associated with rationality. While in the dominant high cultures of nineteenth-century Iran and Europe ornamentation generally represented beauty, wealth, and taste, Farrokh-Khan formulates it as a sign of wastefulness, indolence, and an affront to the purity of measured utilitarian rationality. Almost half a century later, in modernist writings the same argument shaped the discourse against architectural ornament. ${ }^{257}$

This radical characterization of ornamentation as a kind of decadence was not entirely shared by all of the travelers, particularly Abolhasan. While Farrokh-Khan backhandedly categorizes decorative arts among "secular affairs" that need to be measured rationally, Abolhasan ascribes to a more spiritual conception of the arts, which is evident in his rather emotional fondness of paintings. ${ }^{258}$ While his discussions of other types of decoration are limited to general mentions of decorative material, ${ }^{259}$ paintings are frequently detailed in his memoir. Abolhasan often shares a general description about the subjects of his favorite paintings, none of which include urban landscapes. ${ }^{260}$ Abolhasan observed works of art in a variety of different spaces, from ships to rehabilitation facilities for the disabled. ${ }^{261}$ Nevertheless, through a curious insistence to note the high prices commanded by paintings, ${ }^{262}$ Abolhasan associates a royal quality with this Farangi artwork. ${ }^{263}$ "Most lords," he notices, "have paintings in their houses that in total are worth more than 1000 tomans." 264 Upon return to Iran, Abolhasan decorated his own "highly ornamented" house with numerous European 
paintings, "among which was placed, in a conspicuous situation, a picture of himself." 265

The attention that other travelers paid to ornamentation drastically faded once they arrived in Farangestan. In his brief writings in Iran, Mirza Saleh mentions many of the ornamental elements he sees in Isfahan and Tehran as signs of their architectural value. ${ }^{266}$ His mentions of Farangi ornament and decoration are in contrast very limited, ${ }^{267}$ and mostly in relation to murals. ${ }^{268}$ Rezaqoli's writings show a similar pattern. Early in his diary, Rezaqoli writes: "[St. Paul's Cathedral (see Plate 3)] is a magnificent building with moldings and carvings that dazzles the mind. And on top of the church, as well as all around it, numerous stone statues of people and bizarre animals and birds are engraved and carved." 269 What makes this rather detailed description more interesting is the fact that it was written before Rezaqoli personally visits London. In this passage he is actually reporting on Vali's observations. Later, however, and while other sources attest to his interest in woodcarving, for example, ${ }^{270}$ Rezaqoli's writings on ornamentation considerably decline. A particular observation by Rezaqoli about calligraphy explains the gradual shift in his understanding of decorative art. Mirroring Farrokh-Khan's concern that such ornamentation may be trivial and beneath the proper dignity of the forward-looking Farangi ideals of utility, efficiency, and functionality, Rezaqoli states: "In England, everyone can read and write, but they have no interest in calligraphy. They say the ability to apply reading and writing is sufficient and any attempt in the arts of handwriting is a waste of time and useless." 271

Interestingly, the expressions of reservations about ornament in the diaries seem to have little to do with Islamic prohibitions, which generally discourage representational depictions of living objects. These prohibitions had been relatively lax in Iran from the late seventeenth century onward, especially among the upper classes, and Shi'a shrines of the time featured large representational murals, many of which still survive today in Isfahan. It is therefore not surprising to see several of the travelers expressing enthusiasm for Farangi religious iconography and depictions of human figures. The concerns about ornament, when they do arise in the memoirs, have little to do with religious scruples, but instead focus on the "uselessness" of such trivialities in the majestic vision of the utopian future.

\section{Spatial lacunae}

The content of the memoirs is significant not only in what the travelers praise, but also in what they criticize, and their intentional or unconscious omissions. If the glorification and idealization of Farangestan is a broad theme throughout the travelogues, then the projected outlines of this ideal come even more clearly into focus when we identify those aspects of Europe that were rejected or left out. As rare as they may be, the travelers' suspicious silences and negative comments merit particular attention. 


\section{Imagining the modern}

When studying the early depictions of modern Europe in Arab novels, el-Enany observes that earlier encounters were characterized by enchantment and criticality appears only in later writings. This later criticality was skewed by what el-Enany calls "a schizophrenic attitude towards Western civilization, which divided it falsely into a set of practical values which were permissible and another of intellectual ones which were not." 272 This pattern is slightly different with Persian writers, who unlike their Arab peers show a marginal level of criticality. Furthermore, the travelers' overall uncritically is not necessarily out of enchantment or even approval - quite often the writers choose to maintain the idealized image of Farangestan through a deliberate silence. While the early Persian travelers to modern Europe applied the dichotomous model of material versus metaphysical to evaluate Farangi achievements, they recognized a clear connection between the two. "The material wisdom (aghl-e ma'ash) [in England]," Abolhasan suggests,

is limitless and of utmost perfection. It is my firm belief that should Iranian people adopt from the English, they will succeed in all their affairs. Once material needs are fulfilled ... metaphysical wisdom (aghle ma'ad) would also prosper. ${ }^{273}$

This formulation may very well be an attempt by Abolhasan to garner the sympathy of his readers, many of whom were suspicious about Farangestan's otherworldly wisdom. Another technique involves broadening the category of secular wisdom to include cultural products - similar to the way Farrokh-Khan formulates the aesthetics of ornament. Farrokh-Khan occasionally revisits the norms with which Farangi culture is evaluated. Mixed-gender dancing, which is not permissible according to most Islamic traditions, is well-received by Farrokh-Khan because "in Farangestan dance is not vulgar and obscene." 274

While the travelers generally refrain from communicating negative opinions about Europe, Abolhasan's outspoken character sheds light on an otherwise unexpressed criticality. Unlike the more self-conscious travelers, Abolhasan seems to have less self-censorship or concern for propriety when it comes to expressing frank disapproval. ${ }^{275}$ This can be seen in his response to an admirer who asks his opinion of a poem: "Your poetry is like urinating in the holy Well of Zamzam. You should put better effort into your writing, as your poems lack all elegance." 276 Additionally, because of Abolhasan's opinionated attitude, he was less easily swayed by his European companions. A certain resolute snobbery informs his outlook when he rejects the offered "delicacy" of asparagus, saying, "expensive or not, in Iran we do not eat the plants that grow wild in the fields for the animals." 277 Another example of Abolhasan's less impressionable character is when he dismisses the classical statuary collection of Lord Elgin, saying that he "would not pay five tomans for the lot of them."278

Many of Abolhasan's negative comments are related to things he considers too uncouth or uncultured to be part of the Farangi ideal. ${ }^{279}$ Earlier in 
this chapter, I mentioned examples of Abolhasan's critical outlook, especially in regard to his distaste for elected officials and the mingling of the classes. Abolhasan also robustly criticizes English customs of dress, even among the royalty:

I found the ladies' dresses unattractive [referring to the Queen of England and the ladies-in-waiting] and I said to my good friend. 'These strange costumes truly depress me'... . As for the English men's clothes, they are immodest and unflattering to the figure, especially their trousers which look just like under-drawers. ${ }^{280}$

In his broader outlook on the European environment, Abolhasan sometimes speaks negatively of the gloom and dank weather of London, its traffic, the crowdedness and human odor of social gatherings (see Figure 4.3), ${ }^{281}$ and in particular, the claustrophobic feeling he experiences in relation to English houses. ${ }^{282}$ To Abolhasan, the plan of English houses was "deficient in ground space, and that the rooms were much too small." 283 He attributes these latter elements to overpopulation, which is certainly not a part of the Farangi ideal:

With great astonishment, I asked "why do English buildings have so little space? Such splendid structures need ten times more area; do your architects prefer it this way?" An informed person responded: "it is because of high population and limited space." 284

Abolhasan also complains in a few passages about the noise of European cities, as well as mentioning some parts of the urban landscape he feels are not as clean and orderly as Farangestan ought to be. These unsavory experiences are inevitably associated with lower-class or commercial districts, again revealing his social prejudices. ${ }^{285}$ Unsurprisingly, Abolhasan voices nothing but disapproval for St. Stephen's Chapel, the building at Westminster that was the meeting place of the British House of Commons. Although it was designed by the celebrated architect Christopher Wren, to Abolhasan the democratic edifice was "not beautiful." 286

For Farrokh-Khan, negative opinions are primarily reserved for experiences that do not meet his criteria of order and cleanliness. Although such criticisms are very rare in his travelogue, they are nonetheless significant. One of the only passages where Farrokh-Khan speaks negatively of people takes place in the Italian city of Civitavecchia:

It was a small port with a population of six or seven thousand. Its citizens are the most villainous people in the world. All were beggars, rude and uncivil like the people of Karachi and Abbas-dust. There was no sign of order and regulation among them. In all the alleys they asked for money. A French person who was our fellow traveler complained that during his two month travel, he had spent 24 tomans on the beggars. ${ }^{287}$ 


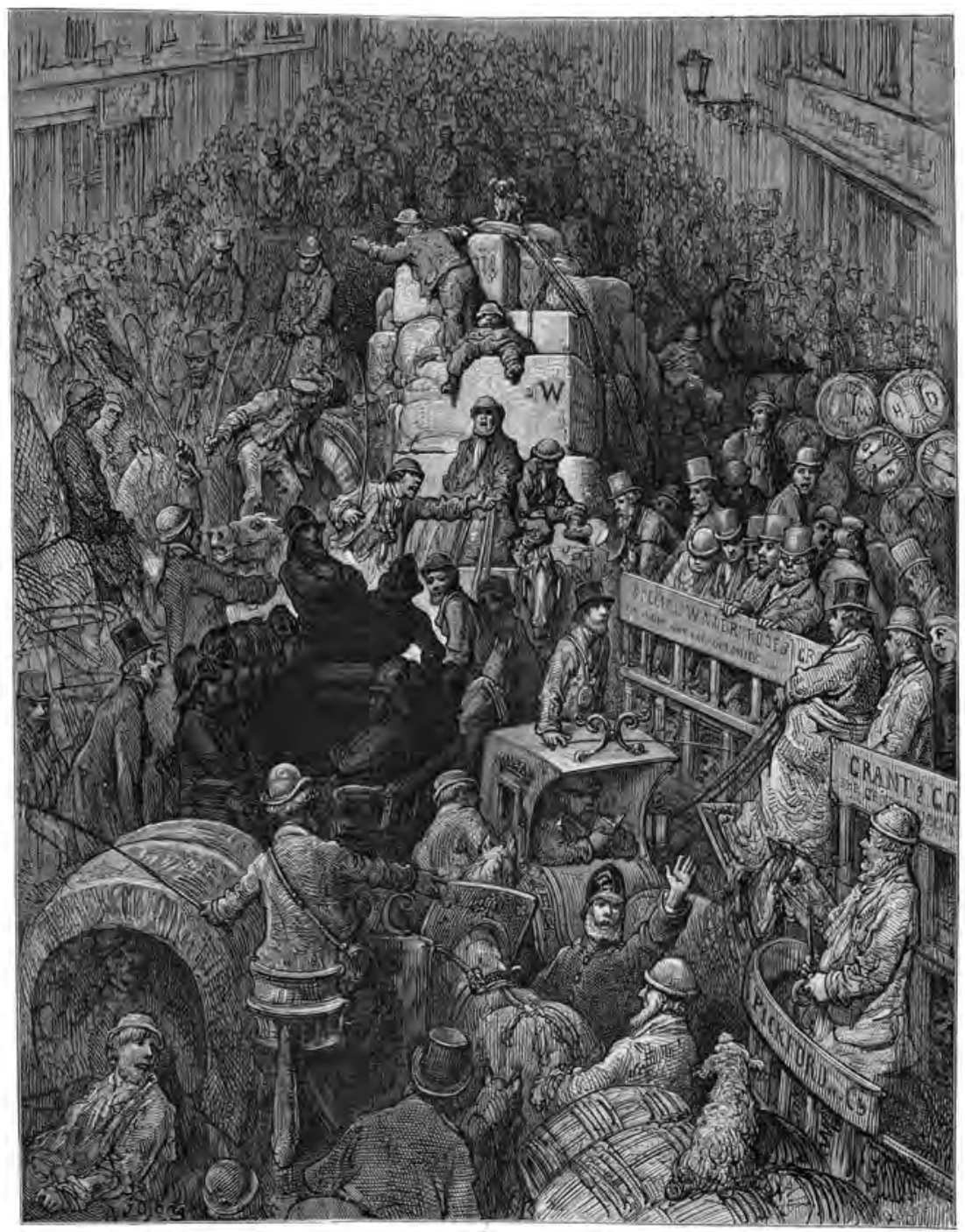

Figure 4.3 Gustave Doré's illustration of a crowded London street, for London: A Pilgrimage, published in 1872 . The dense urban crowding of the city was sometimes described by Abolhasan as oppressive and stifling.

Source: The British Library.

In this description the disordered and shabby inhabitants of the Italian city are metaphorically distanced from Farangestan, by directly associating them with the "backward" cities of Karachi and Abbas-dust (Pakistan and Iran). 
For further emphasis, these unsavory characters are then contrasted against the traveler's legitimate Farangi companion.

Other passages from Farrokh-Khan's memoir indicate similar displeasure when the Farangi ideal is tainted by an aesthetic that he finds distasteful and regressive. Referring to the ornate Thai furniture that decorates a room at Buckingham Palace, Farrokh-Khan complains, "Although everything was expensive, they lacked all proportion, configuration, and scale. Nothing among them was approvable." ${ }^{288}$ Proportion, configuration, and scale are all important concepts in Farrokh-Khan's vision of the well-ordered city, which perhaps explains how disappointed he was to find such a lacuna of taste at the very center of British royalty. The subtle reservations expressed here may be a way of contrasting the futuristic grandeur of the Farangi state against a certain tendency toward capricious traditionalism in the halls of hereditary power.

Reservations aside, in their enthusiasm to celebrate the wonders and utopian vision of Farangestan the travelers usually seem willing to obscure or cover up negative aspects of their experiences. Mirza Saleh, despite his rational and analytical approach, ${ }^{289}$ seems incapable of finding any imperfections in England. When writing about Iran and Turkey he occasionally notes uneven roads, filthy streets, small houses, decaying structures, and uneducated people, ${ }^{290}$ but his approval of Farangestan is unequivocal, extending even to its "perfect agriculture" and "most excellent horses." ${ }^{291}$ Rezaqoli's similar preference for reporting on the virtuous aspects of the people, places, and objects that he observes seems associated with his positive and uncomplaining attitude. ${ }^{292}$ At most, he reveals an indirect displeasure by stating that Europeans have a tendency to be boastful: "They seek fame, and once someone has acquired a minor accomplishment, it is displayed in thousands of ways. The love of worldly affairs is over-appreciated, and unlike the Oriental, they are not hospitable to strangers." 293

It is possible, however, that a stronger sense of resentment lurks beneath the surface. The paradisiacal image of London that Rezaqoli usually renders in his writings is contradicted by reports from his companion Fraser. According to Fraser's descriptions, Rezaqoli and his brothers often grew exhausted and claustrophobic in the city, in the same manner that was sometimes described by Abolhasan. Rezaqoli writes that "in London there is absolutely no sign of smoke and steam." ${ }^{294}$ Fraser, in contrast, says that the princes "were heartily sick of London ... its noise, and its rattle, and its dust, and bad air." ${ }^{295}$ While Rezaqoli, as his diary suggests, did not tolerate the slightest criticism towards London, ${ }^{296}$ his private discussions with Fraser suggest a deep discontent with the city: "I am tired of this London, I can't breathe in it, I am choked." ${ }^{297}$ In another passage Fraser reports Rezaqoli as saying, "Who would live in London, with its dust, and its heat, and the eternal whirr! Birr! Jirr! Of its streets, with their thousand carts and carriages, and uproar?" ${ }^{298}$ London's traffic, as rendered in Rezaqoli's diary, is no longer exhausting and unbearable, but a sign of 


\section{0}

Imagining the modern

progress: "London is so fully occupied and developed," writes Rezaqoli, "that sometimes the carriages are so jammed that they block the road and disrupt movement." 299

It is probably impossible to come to certainty about Rezaqoli's true feelings on the matter, or to parse out the conflicting imperatives and perceptions that lead to this discrepancy in the textual record. ${ }^{300}$ However, this contrast indicates how strikingly and stubbornly affirmative the Persian travelers' representations are in the memoirs, lending an almost inevitable positive spin to everything associated with the Farangi ideal.

The absence of stress, pollution, overcrowded cities, or social conflict throughout most of the travelogues has to be taken with a grain of salt, particularly as the authors would likely have been accustomed to wealthy environments in their homeland that were spacious and calm relative to the social bustle and industrial development of Europe ${ }^{301}$ (see Figure 4.4). Part of the explanation for the indefatigable optimism and wonder in the journals is the travelers' privileged position: as high-ranking visitors they were

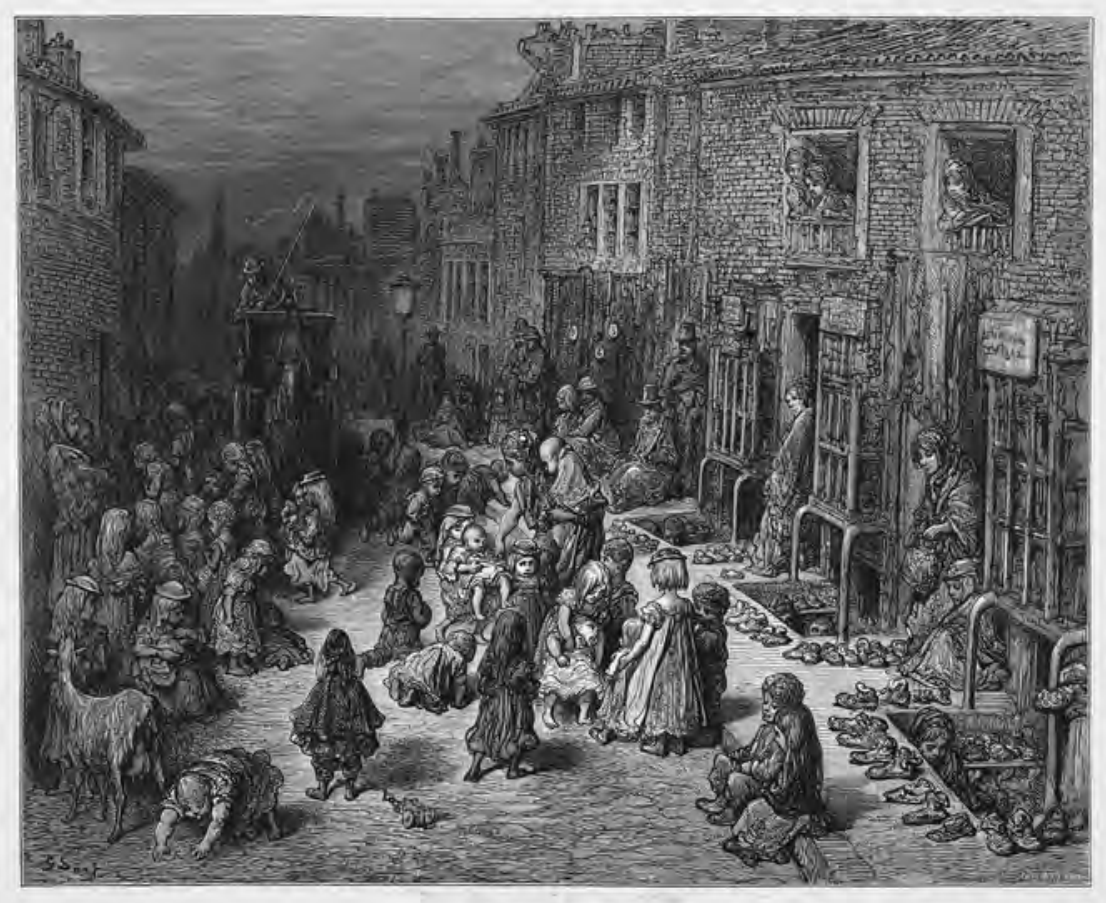

Figure 4.4 The travelers remain silent about the challenging urban conditions of the working-class quarters in major industrial cities of Europe, such as London.

Source: London: A Pilgrimage, illustrated by Gustave Doré in 1872. 
likely shielded from the most degrading aspects of industrial-era European life. As Friedrich Engels pointed out during the same time period,

owing to the curious lay-out of the town it is quite possible for someone to live for years in Manchester and to travel daily to and from his work without ever seeing a working-class quarter or coming into contact with an artisan. He who visits Manchester simply on business or for pleasure need never see the slums, mainly because the working-class districts and the middle-class districts are quite distinct. ${ }^{302}$

It is hard to believe, however, that the pollution, tumult, and overcrowding occasionally mentioned by Abolhasan could go entirely unnoticed by the other travelers. The reason that these factors are not mentioned is more likely because they are deemed irrelevant to the ideal vision of Farangestan that the authors wished to paint for their Persian audiences. It is true that to an enchanted observer there is nothing but beauty in what he sees. But the travelers were more than just observers of an imagined Other. They were also narrators of an ideal future, not only reporting, but also reconceptualizing, designing, and polishing the Farangi utopia.

\section{Notes}

1 Kevin Lynch, The Image of the City.

2 See Mohsen Habibi, Az Shar Ta Shahr; Vahid Vahdat, "A Study on Urban Development."

3 Shirazi, Majmueh Safarnameha, 268.

4 Ibid., 109, 366, 418.

5 Abolhasan Ilchi, Heyratnameh, 275.

6 Ibid., 291.

7 Ibid., 339.

8 In his descriptions of the fireworks, Rezaqoli mentions a variety of geometric shapes such as circle, trigon, tetragon, pentagon, and hexagon (Rezaqoli Mirza, Safarnameh, 410).

9 Ibid., 242.

10 Ibid., 185, 247, 701.

11 Shirazi, Majmueh Safarnameha, 20, 21, 24, 27, 411, 414.

12 Ibid., 78. Emphasis added.

13 Aminoddowleh, Makhzanol Vaqaye', 305.

14 Ilchi, Heyratnameh, 123; see also p. 88 where the "wide straight paths" reemerge.

15 Aminoddowleh, Makhzanol Vaqaye', 185.

16 Similar to Farrokh-Khan, Rezaqoli finds a relationship between pavement and the drainage of excess rain and ground water. In Damascus, Rezaqoli is content to see "all streets are paved with granite, so masterfully that no sewage will remain on it" (Rezaqoli Mirza, Safarnameh, 246).

17 See Gülru Necipoğlu, "Framing the Gaze."

18 Ilchi, Heyratnameh, 126.

19 Ibid., 329.

20 Rezaqoli Mirza, Safarnameh, 279. The similar kucheh-bagh pattern is detected by Rezaqoli near Brussels: "Throughout the seven miles length of this street, 


\section{Imagining the modern}

large trees on both sides shade the whole path. What a pleasant place it was and what charming trees we saw" (ibid., 603).

21 Fraser, Narrative of the Residence, 284.

22 Momtahenoddowleh, the first Iranian who studied architecture in Europe, mentions the streets in his memoir: "At that time, Farrokh Khan Aminoddowleh, may his soul rest in peace, had ordered to pave the streets of the arg with polished cubic stones" (Mahdi Khan Momtahenoddowleh, Khaterat-e Momtahenoddowleh, 44).

23 See Vahid Vahdat, "Spatial Discrimination."

24 Aminoddowleh, Makhzanol Vaqaye', 171.

25 Shirazi, Majmueh Safarnameha, 115, 264, 314, 362, 404, 408.

26 Ibid., 408.

27 Rezaqoli Mirza, Journal of a Residence, 22.

28 Tavakoli-Targhi, Refashioning Iran, 54.

29 This desire for the fairy-like residents of Farangestan is evident in the studied travelers, as for example Abolhasan, Teymur Mirza (Rezaqoli's brother), and several of their servants fell in love with Farangi women. Ostad Mohammadali Chakhmaqsaz, who concurrent to Mirza Saleh was sent on study-abroad mission to England, married a British lady (Rezaqoli Mirza, Journal of a Residence, 94; Shirazi, Majmueh Safarnameha, 348; Margaret Morris Cloake, "Foreword and Footnotes," 8).

30 Aminoddowleh, Makhzanol Vaqaye', 171.

31 Ibid., 171, 174, 179, 185, 276, 279, 286, 366.

32 Ibid., 371.

33 Ilchi, Heyratnameh, 269.

34 Shirazi, Majmueh Safarnameha, 313.

35 Rezaqoli Mirza, Journal of a Residence, 22, 371.

36 For example, see Aminoddowleh, Makhzanol Vaqaye', 64, 174, 260, 262, 302; Rezaqoli Mirza, Journal of a Residence, 391. Safarnameh, 70, 351; Shirazi, Majmueh Safarnameha, 324.

37 Rezaqoli Mirza, Safarnameh, 224, 632; Aminoddowleh, Makhzanol Vaqaye', 274.

38 Rezaqoli Mirza, Journal of a Residence, 251.

39 Ibid.

40 Fraser in several cases mentions that the princes were tired of London and preferred to spend their time in the county (Fraser, Narrative of the Residence, 175, 273).

41 Ibid., 175.

42 Ibid., 176.

43 Ibid., 85-87.

44 Rezaqoli Mirza, Journal of a Residence, 137, 154.

45 Shirazi, Majmueh Safarnameha, 32, 182.

46 James Justinian Morier, A Journey through Persia, 352.

47 Ilchi, Heyratnameh, 276.

48 Ibid., 285.

49 Aminoddowleh, Makhzanol Vaqaye', 340.

50 Abolhasan found the fact of great heirat (peculiarity) that "all flowers and plants and every kind of fruit from all seasons and all regions of the world were cultivated in these gardens" (Ilchi, Heyratnameh, 305; Rezaqoli Mirza, Journal of a Residence, 351).

51 Safarnameh, 383, 391, 408, 422, 427, 624, 682; Shirazi, Majmueh Safarnameha, 29, 31, 32, 324, 325; Ilchi, Heyratnameh, 143, 243, 276, 285.

52 A Persian at the Court, 78.

53 Rezaqoli Mirza, Journal of a Residence, 129. 
54 Aminoddowleh, Makhzanol Vaqaye’, 93, 190, 217, 276.; Rezaqoli Mirza, Safarnameh, 82, 476.; Shirazi, Majmueh Safarnameha, 321. Ilchi, A Persian at the Court, 70.

55 Rezaqoli Mirza, Safarnameh, 428.

56 Journal of a Residence, 409.

57 Aminoddowleh, Makhzanol Vaqaye', 214.

58 Ilchi, A Persian at the Court, 78.

59 Rezaqoli Mirza, Safarnameh, 224.

60 Ilchi, A Persian at the Court, 70.

61 M. R. Ghanoonparvar, In a Persian Mirror.

62 Rezaqoli made this comment in reference to a performance of The Siege of $\mathrm{La}$ Rochelle that he had attended at the London Opera House (Rezaqoli Mirza, Safarnameh, 393).

63 Hafez, "Poetry of Hafiz Translated by Shahriar Shahriari," 7.

64 The premodern architecture of central Iran introduced many innovative architectural solutions to the climatic challenges of the region. Examples include badgirs (wind-catching towers erected upon the summer section of a house), qanats (subterranean water distribution canals), yakhchals (ice producing and storage structures), and kabutar-khanehs (pigeon towers that collect pigeon dung to be used as fertilizer).

65 Shirazi, Majmueh Safarnameha, 293.

66 Ibid., 264, 404.

67 Ilchi, A Persian at the Court, 62.

68 Rezaqoli Mirza, Safarnameh, 319.

69 Rezaqoli discusses views twice in his memoir. Farrokh-Khan's single mention of views happens on his visit to Sanssouci, Frederick the Great's summer palace in Potsdam, Prussia (Aminoddowleh, Makhzanol Vaqaye', 405). Abolhasan often discussed views when the building height allowed a wider scope. At Kenwood House in Hampstead, he wrote: "When I ascended to the top floor of this high palace, I felt I could count all the houses of London, which was at a 200 miles distance from us" (Ilchi, Heyratnameh, 285). At the dome of St. Paul's Cathedral (see Plate 9), Abolhasan similarly praised the "splendid view of London and the surrounding countryside for ten miles" (A Persian at the Court, 224).

70 Morier writes,

the windows of his apartment had a fine view of the great extent of Constantinople, the Seraglio point, the shipping in the harbour, the palaces of Dolma Baghche [Dolmabahçe Palace], and part of the sultan's fleet, (consisting of two three-deckers and live seventy-fours, at their anchorage,) and all the activity spread over the Bosphorus by the numerous vessels of all descriptions rowing about in every direction, altogether forming the most beautiful picture that an imagination the most fertile could picture to itself. . . Whenever I called his attention to it, he seemed to shrink from the observation.

(Morier, A Journey through Persia, 353)

71 At the royal living room in the Winter Palace, St. Petersburg, Mirza Saleh states, "Opposite to the mentioned room, Neva River and its many ships are observable. The view of the river adds much charm to the prominence of the royal house." For more information about Mirza Saleh's observations at the Winter Palace and for other examples, see Shirazi, Majmueh Safarnameha, 111, 188, $325,371$.

72 Ilchi, Heyratnameh, 75, 111, 241.

73 To Farrokh-Khan, the layout of Persian buildings was primarily distinguished by the "reflecting pool in the middle [of its courtyard]" (Aminoddowleh, Makhzanol 


\section{Imagining the modern}

Vaqaye', 171). Similarly, a centrally located fountain that Abolhasan observed in a Farangi house was associated with Persian traditions of architecture: "The house had a pool of water in an Iranian manner, and a water-jet was placed right in the middle" (Ilchi, Heyratnameh, 280).

74 See Hans E. Wulff, "The Qanats of Iran."

75 Rezaqoli Mirza, Safarnameh, 319.

76 Ilchi, A Persian at the Court, 337.

77 The travelers' dissatisfaction with the architectural treatment of water is evident for example in Mirza Saleh's account. While in the first thirty pages of his memoir, which are dedicated to his travels in Iran, Mirza Saleh discusses pools ten times, he does not mention fountains even once in his travel to Europe. (Shirazi, Majmueh Safarnameha, 7, 10, 12-14, 27, 30-32). A rare compliment to Farangi fountains can be found in Abolhasan's account of Ouseley's country house, where he refers to the pool as "the envy of the Fountain of Life" (Ilchi, A Persian at the Court, 86).

78 A Persian at the Court, 79.

79 Fraser, Narrative of the Residence, 16.

80 Ibid., 160.

81 For more on the concept of spatial affordance, see James J. Gibson, The Senses Considered as Perceptual Systems.

82 Ilchi, Heyratnameh, 358.

83 Rezaqoli Mirza, Safarnameh, 335.

84 Ilchi, Heyratnameh, 104.

85 Abolhasan was amazed by the "royal quality" of Brandenburgh House, where he particularly mentions a small opera, a gallery, and a private library (ibid., 241). In two other mansions, he similarly makes note of the private theatres and libraries (A Persian at the Court, 234; Heyratnameh, 321). Rezaqoli was also charmed by the separate dancing rooms and libraries that he saw in his visit to Windsor Castle (Rezaqoli Mirza, Safarnameh, 425-427).

86 Abolhasan, for example, insists on presenting the topic through transliterations of functional spaces such as "drawing room" and "dining room" (Ilchi, A Persian at the Court, 137, 211).

87 Shirazi, Majmueh Safarnameha, 314.

88 Both Farrokh-Khan and Abolhasan were initially amazed to see big rooms where the servants collected and stored the visitor's coats (Ilchi, Heyratnameh, 215).

89 Rezaqoli Mirza, Safarnameh, 505.

90 In his visit to the Hôtel de Ville in Paris, Farrokh-Khan gives a thorough account of how different rooms are intended for different functions:

One section of this complex is specified for the mayor [Baron Haussmann] and his dependents. To be more specific, the first floor is assigned to his wife and children, the second floor to parties and serves as a reception for ambassadors and the noble visitor from different countries who come to see Paris. The third floor is intended for municipal office-work of almost one hundred clerks. . . A section of the building is designated for big ceremonies, where the huge population of the city dwellers can gather and enjoy the events. A part is for the city council, a part for the experts, and a part for writers and administrators.

(Aminoddowleh, Makhzanol Vaqaye', 207)

91 The urban typologies that Mirza Saleh uses in his categorization system include churches, parks, museums, schools, bridges, and theaters.

92 Ilchi, Heyratnameh, 61, 75, 231, 318.

93 Aminoddowleh, Makhzanol Vaqaye', 169.

94 In the fifth, ninth, and tenth articles of the law, which was passed in June 1907 by the first parliament of Mashruteh, the municipality becomes responsible for assisting the government in the construction of hospitals, asylums, nursing 
homes, libraries, museums, workhouses, and exposition venues (Mohamad Tavakoli-Targhi, "Tajaddod-e Ruzmarreh," 451).

95 Ilchi, Heyratnameh, 97.

96 Ibid., 349.

97 Ibid., 342.

98 Ibid., 269, 348.

99 Aminoddowleh, Makhzanol Vaqaye', 182.

100 Tavakoli-Targhi, “Tajaddod-e Ruzmarreh," 421-422.

101 "The state officials," as a reported in a newspapers article in 1851, "have made great efforts to keep Tehran clean - they have assigned officers to monitor garbage and trash [all around the city]" (Editorial, "Darolkhelafeh Tehran"). These urban services and regulations were not limited to the capital. In Hamedan, the same newspaper reports, "[officials] have mandated regulations to relocate slaughter houses . . . also to sweep the streets, dispose the garbage, and keep the houses, streets, and neighborhoods clean" ("Hamedan").

102 Tavakoli-Targhi, "Tajaddod-e Ruzmarreh," 421-422.

103 Shirazi, Majmueh Safarnameha, 144.

104 Egyptian travelers visiting Europe evinced a similar obsession with cleanliness and order. As Mitchell shows, the travel diaries published in Cairo, "devote hundreds of pages to describing the peculiar order" (Timothy Mitchell, "The World as Exhibition").

105 Fraser, Narrative of the Residence, 244; Rezaqoli Mirza, Safarnameh, 318, 351, 358; Ilchi, Heyratnameh, 258, 265, 312.

106 Abolhasan, for example, admires the organization with which thirty thousand different books of science, medicine, and history were stored in a library because of its efficiency and convenience (Heyratnameh, 318).

107 Siegfried Kracauer and Thomas Y. Levin, The Mass Ornament.

108 Fraser, Narrative of the Residence, 122.

109 Ibid., 112.

110 Ibid., 157.

111 Ibid., 250, 255.

112 Morier, A Journey through Persia, 352.

113 Abolhasan, for example, admired the well-ordered streets of Malta, the identically designed paths in a private garden, and the indistinguishable streets of Vauxhall Gardens (see Ilchi, Heyratnameh, 102, 284, 331).

114 Shirazi, Majmueh Safarnameha, 263.

115 Abolhasan's description of a Farangi residential area is a good example:

Splendid houses line both sides of the street. They all look alike; the name of the owner is painted on each door. . . the first story is built of stone and the other three of brick and stucco... the windows are glazed with matching panes. Stables and carriage-houses are conveniently place behind each house.

(Ilchi, A Persian at the Court, 62)

116 Rezaqoli Mirza, Journal of a Residence, 256.

117 Istanbul, Mirza Saleh explains, "has experienced multiple major earthquakes that have caused great damage to the city. Today an officer is assigned to inspect building heights so that they do not exceed eight zar'" (Shirazi, Majmueh Safarnameha, 402).

118 St. Petersburg's houses, Abolhasan suggests, "were built from wood, many of which burnt down. Subsequently, an order was issued that mandated the use brick and stone for any construction. Gradually all walls were built with brick and stone" (ibid., 110). To see Abolhasan's detailed explanation of building codes that were implemented after the Great Fire of London, see ibid., p. 262.

119 Ilchi, A Persian at the Court, 62. 


\section{Imagining the modern}

120 Rezaqoli suggests: “There are in the streets, on both sides, separate sidewalks, for those that pass on foot, so that they are never interrupted by carriages or horses, which have their separate path, and they do not interfere with each other" (Rezaqoli Mirza, Journal of a Residence, 256). One side of the sidewalk is for incoming and the other is for outgoing traffic.

121 Safarnameh, 517.

122 "Even the prince," as Abolhasan had astonishingly witnessed during a military parade, "must salute his commander in chief" (Ilchi, A Persian at the Court, 203).

123 Ibid., 63.

124 Heyratnameh, 65, 152

125 Mirza Saleh feels obliged to mention instances where he encounters spaces that do not meet his expectancy of Farangi order. "Buildings [in Moscow]," he surprisingly explains, "do not follow any order" (Shirazi, Majmueh Safarnameha, 78).

126 Before his arrival to Britain, Mirza Saleh writes, "The code in Farangestan is that they locate their living area on the second floor" (ibid., 110).

127 Ilchi, A Persian at the Court, 212.

128 Farrokh-Khan does not indicate the source of his information when making this observation. We can assume that either he must have heard about "the plan of state architects" from a French engineer he met in the train, or else he is simply formulating his preconception on the matter (Aminoddowleh, Makhzanol Vaqaye', 185).

129 Ibid., 205.

130 Ibid., 380.

131 Shirazi, Majmueh Safarnameha, 178, 181, 266, 339; Rezaqoli Mirza, Safarnameh, 539 (to see Rezaqoli's discussion of city councils).

132 Shirazi, Majmueh Safarnameha, 110.

133 Ibid.

134 Ibid., 308.

135 Ilchi, Heyratnameh, 97, 349.

136 Shirazi, Majmueh Safarnameha, 308.

137 Rezaqoli Mirza, Journal of a Residence, 259.

138 Ilchi, A Persian at the Court, 155.

139 Rezaqoli, for example, shows interest in the sewage system in Damascus, particularly because it keeps the streets clean (Rezaqoli Mirza, Safarnameh, 246).

140 Shirazi, Majmueh Safarnameha, 261.

141 Farrokh-Khan, who considered Thames Tunnel as one the four finest structures in the world, was mightily fascinated with its sweeping services.

142 Shirazi, Majmueh Safarnameha, 314.

143 Rezaqoli Mirza, Safarnameh, 575.

144 Ibid.

145 Ilchi, Heyratnameh, 76.

146 Rezaqoli Mirza, Safarnameh, 571, 575, 576, 607. Aminoddowleh, Makhzanol Vaqaye', 217.

147 Shirazi, Majmueh Safarnameha, 263; Aminoddowleh, Makhzanol Vaqaye', 183, 193; Rezaqoli Mirza, Safarnameh, 372, 563.

148 Ilchi, A Persian at the Court, 62.

149 For more information about cheraghan (illumination) and atashbazi (fireworks) in the courts of Safavid Persian kings, see Necipoğlu, "Framing the Gaze," 311.

150 Abolhasan repeatedly referred to public lighting as a great heyrat (wonder) (Ilchi, Heyratnameh, 131, 156).

151 Rezaqoli makes this comment at his first stop in a Farangi city, in Bath, England (Rezaqoli Mirza, Journal of a Residence, 256). 
152 Farrokh-Khan's discussion of Farangi lighting systems appears on the beginning of his description about Paris (Aminoddowleh, Makhzanol Vaqaye', 190).

153 Ilchi, Heyratnameh, 79, 131, 218.

154 In this passage, Rezaqoli communicates his amazement when, for the first time, he is seeing Farangi cities on his way to London (Rezaqoli Mirza, Safarnameh, $335)$.

155 Journal of a Residence, 272.

156 Safarnameh, 372, 562.

157 Journal of a Residence, 279.

158 Aminoddowleh, Makhzanol Vaqaye', 188.

159 "The four sides of the garden," he writes, "are lined with wooden arcades covered with painted cloth and hung with coloured lanterns - gold, red and white ... the lighting from coloured lanterns gave the impression of enamelwork" (Ilchi, A Persian at the Court, 261). Similar mentions of multicolored light fixtures, particularly the crystal, gold, or silver ones, are frequent in Abolhasan's diary. For more examples, see Heyratnameh, 156; A Persian at the Court, 54, 99, 211, 261.

160 Heyratnameh, 156, 160.

161 Aminoddowleh, Makhzanol Vaqaye', 188, 193, 208, 235.

162 Surah 24:35 Al Nur, 2996-3002.

163 The first parliament of Mashruteh enacted a municipal governance law, known as Ghanun-e Baladiyeh. The fourth article of this law, passed in June 1907, puts the municipality in charge of "providing city light" (Tavakoli-Targhi, "Tajaddod-e Ruzmarreh," 451).

164 "This 8 mile street," Farrokh-Khan writes,

is at night lit with two rows of lanterns that glow like two orderly chains of fire. Yet, the more dominating lights come from thousands and thousands and millions and millions of chandeliers, wall fixtures, and colored lamps that are placed next to the windows of buildings on both sides of the street. The first floors of all the buildings are stores and shops . . . that have a minimum of thirty to forty lamps each. Big stores, hotels, cafés, and theatres have one thousand to two thousand light fixtures. And above their entrances the name of the buildings and their owners are printed with fire ... Ten to twelve thousand carriages are constantly traversing in the street, each with two lanterns in the front.

(Aminoddowleh, Makbzanol Vaqaye', 193)

165 Ilchi, Heyratnameh, 319.

166 Rezaqoli Mirza, Safarnameh, 525.

167 Shirazi, Majmueh Safarnameha, 193.

168 Ilchi, A Persian at the Court, 199.

169 Heyratnameh, 256.

170 A Persian at the Court, 72.

171 Shirazi, Majmueh Safarnameha, 317.

172 Fraser, Narrative of the Residence, 271.

173 Rezaqoli Mirza, Journal of a Residence, 62. Rezaqoli similarly appreciated the idea that the King of Great Britain, "goes incognito about the streets, conversing with whom he pleases" (ibid., 90).

174 Ilchi, Heyratnameh, 307.

175 "Letter from the Persion Envoy."

176 Abolhasan, for example, was "mightily astonished" to see excellent buildings, like a hospital in Malta, "should be the habitation of the sick" (Morier, A Journey through Persia, 356).

177 Ilchi, A Persian at the Court, 252.

178 Heyratnameh, 264, 269. 


\section{Imagining the modern}

179 "Letter from the Persion Envoy."

180 A Persian at the Court, 210-212.

181 Ibid., 137.

182 Shirazi, Majmueh Safarnameha, 113.

183 Rezaqoli Mirza, Safarnameh, 488.

184 Ilchi, Heyratnameh, 330.

185 Describing the welcoming party held for the Tsar's brother, Farrokh-Khan writes, "The city of Paris was decorated like eyd. Stores, shops, and the bazaar were decorated, the city lights were increased, and the night was illuminated. Parties and dances were held in all streets and neighborhoods" (Aminoddowleh, Makhzanol Vaqaye', 282).

186 Shirazi, Majmueh Safarnameha, 280, also see 336.

187 Aminoddowleh, Makhzanol Vaqaye, 302.

188 Ibid., 215.

189 Rezaqoli Mirza, Safarnameh, 371, 488, 539.

190 While the travelers were somewhat divided in their formulation of public space as means for spatial integration, they all felt great pleasure when experiencing the public life of modern squares, streets, and parks. Abolhasan frequently mentions the joy and relief he felt in his every day visit to Portman Square (Ilchi, Heyratnameh, 255, 259, 336). Rezaqoli and his brothers, as their English companion reports, enjoyed driving through the crowded streets and "never tired of looking down the long lines of the streets that they passed." Rezaqoli had repeatedly stated that, "The streets and the shops are themselves about the best shows in London: what riches, what an endless variety of goods! One cannot tire of them" (Fraser, Narrative of the Residence, 163).

191 Abolhasan who initially defined parks as vast maidans (open fields), where young and old, men and women, "nobles and commoners alike" go for "pleasure and relaxation," soon realized that most parks are "enclosed with fencing." At Vauxhall Gardens, Abolhasan initially mentions that "some 10,000 ladies and gentlemen and ordinary folk were there, enjoying themselves." A few paragraphs later, however, he mentions a covered place in the park, accessible only to those who could pay its high entrance fee (see Figure 3.1). Abolhasan's portrayal of a concert hall is similarly focused on how it is exclusively accessible by the nobility. The concert hall, in Abolhasan's words, "is an extremely large building with a high ceiling and an elevated menbar [stage], that except for the nobility and the lords, no ordinary folk is allowed to enter" (Ilchi, A Persian at the Court, 78, 217, 222, 261, 262.; Heyratnameh, 258).

192 A Persian at the Court, 88. See also Heyratnameh, 154, 155, 336. Abolhasan's rendering of public squares as exclusively accessible to certain groups of people is particularly meaningful when contrasted with Mirza Saleh's descriptions. "In their neighborhoods," Mirza Saleh writes

they have multiple gardens which they call a 'square.' Each is a square area similar to a courtyard. . . . The neighbors each pay an annual fee to the gardener to maintain the garden. . . London's air stays purified because of this, it also serves as an ornament to the city, and people can enjoy their time strolling in the gardens.

(Shirazi, Majmueh Safarnameha, 285)

193 Abdolhosein Ayati, Atashkadeh-Ye Yazdan, 223.

194 Ibid., 225.

195 The hierarchical procession of space in premodern houses in the central regions of Iran often corresponds with a patriarchal structure. The most valued space in a Persian residence, called shah-neshin (royal parlor), is designated for guests and elders of the family. 
196 Fraser, Narrative of the Residence, 271.

197 Ilchi, Heyr atnameh, 105, 169, 258.

198 Ouseley, for example, had assured Abolhasan that by seating him on his right, "the Minister wished to show greater honour and friendship" (A Persian at the Court, 96).

199 Aminoddowleh, Makhzanol Vaqaye', 286.

200 Shirazi, Majmueh Safarnameha, 111.

201 Aminoddowleh, Makhzanol Vaqaye', 250 (emphasis added).

202 Shirazi, Majmueh Safarnameha, 268.

203 The writers approach spatial symmetry with a similarly approving tone, yet from slightly different angles. Unlike Mirza Saleh and Farrokh-Khan, who associate symmetry with power, Rezaqoli's few mentions of symmetrical patterns amount to his appreciation of a perfected order. Similarly, Abolhasan's take on symmetry, for example his appreciation of symmetrically paired houses in Plymouth streets and the two symmetrical blocks of the Naval Hospital (Greenwich Hospital), designed by Christopher Wren, seem exclusively aesthetic (Rezaqoli Mirza, Safarnameh, 338, 358. Ilchi, Heyratnameh, 123, 269).

204 Rezaqoli Mirza, Safarnameh, 394.

205 See Javad Tabatabai, Ta'ammoli Dar Bareh-Ye Iran, 2.

206 Rem Koolhaas, "Bigness and the Problem of Large," 494 (emphasis in the original).

207 Rezaqoli Mirza, Safarnameh, 633.

208 For Mirza Saleh's glorification of the large church spire at Salisbury Cathedral (see Plate 10) and the large naval hospital at Plymouth (Devonport), see Shirazi, Majmueh Safarnameha, 178, 187. For similar examples of architectural grandeur in the other travel accounts, see, for example, Reza Qoli Mirza, Safarnameh, 422, 427, 450, 493, 505, 616, 623, 624; Ilchi, Heyratnameh, 158, 165, 222, 241, 290, 331, 334.

209 Rezaqoli, for example, in separate instances communicates that residential apartments in Bath, London, and Frankfurt are four to five stories high (Rezaqoli Mirza, Safarnameh, 338, 517, 614).

210 Abolhasan mentions the number of floors in multiple buildings, including the Royal Hospital at Chelsea, Greenwich Hospital, the House of Commons, and a major library at London (Ilchi, Heyratnameh, 264, 308, 318, 360).

211 Aminoddowleh, Makhzanol Vaqaye', 166.; Ilchi, A Persian at the Court, 62.

212 Heyratnameh, 264.; Morier, A Journey through Persia, 356.

213 Ilchi, Heyratnameh, 293.

214 Ibid., 328.

215 On his way towards Europe, Abolhasan communicates his assumption that Farangi houses are necessarily multistory. In another occasion, Abolhasan writes that the apartments in Istanbul, "are excellent; like Farangi buildings, they are covered with stone and have 5 stories" (ibid., 75, 90).

216 Fraser, Narrative of the Residence, 60.

217 For example, when Farrokh-Khan visits a military arsenal in Antwerp, Belgium, he indicates that it "didn't have much magnitude" and that it was therefore "not really worth attention" (Aminoddowleh, Makhzanol Vaqaye', 307).

218 Rezaqoli Mirza, Safarnameh, 428.

219 Aminoddowleh, Makhzanol Vaqaye', 286.

220 Ibid., 158.

221 Ilchi, A Persian at the Court, 27, 103.

222 Ibid., 178.

223 Rezaqoli Mirza, Journal of a Residence, 174, 175.

224 Rezaqoli made the same observation for the mortar used in man-made shipyard channels on the banks of the Thames (Safarnameh, 411, 502). 
225 Shirazi, Majmueh Safarnameha, 110, 262.

226 Ibid., 62. Similarly, Abolhasan before his departure for Europe communicates a preexisting image of Farangi architectural material when suggesting that, "the houses [in Istanbul] are excellent; like Farangi buildings, they are covered with stone" (Ilchi, Heyratnameh, 75).

227 Rezaqoli Mirza, Safarnameh, 423, 424, 543, 600, 601, 616, 624. Gold, silver, and crystal are also the three recurrent materials in Abolhasan's descriptions of lanterns (Ilchi, A Persian at the Court, 54, 69, 99; Heyratnameh, 130, 156). While gold, silver, lapis lazuli, and marble are the only materials that Mirza Saleh mentions in his travels through Iran, he changes this appreciative pattern in England to greater attention towards stone (Shirazi, Majmueh Safarnameha, 11-13, 19, 24, 29-32).

228 Ilchi, Heyratnameh, 71, 102, 111, 123, 126, 264; also see A Persian at the Court, 62, 208, 224.

229 Shirazi, Majmueh Safarnameha, 336, 337.

230 Rezaqoli Mirza, Journal of a Residence, 174, 175.

231 Ilchi, Heyratnameh, 158; A Persian at the Court, 112.

232 Shirazi, Majmueh Safarnameha, 336, 337.

233 The appreciation of firmness is by no means exclusive to the Iranian travelers: stability is a common quality that any user would expect from a building. Vitruvius, a first-century Roman author and architect, considers firmitas as one of the three major qualities that a structure should possess (Pollio Vitruvius, Vitruvius: The Ten Books on Architecture).

234 Rezaqoli Mirza, Safarnameh, 242, 266, 303, 306, 307, 311, 316, 338.

235 Ibid., 306, 311, 315.

236 Aminoddowleh, Makhzanol Vaqaye', 340.

237 Rezaqoli Mirza, Safarnameh, 246, 284, 318, 337, 469, 486.

238 Mirza Saleh's mentions of stonework are significantly more detailed when he writes about forts and castles (Shirazi, Majmueh Safarnameha, 78, 109).

239 Aminoddowleh, Makhzanol Vaqaye', 273.

240 Ibid., 158.

241 Rezaqoli Mirza, Safarnameh, 316.

242 Ilchi, Heyratnameh, 230.

243 This expression comes from a Persian proverb that denotes impossibility: "An iron nail cannot pierce a rock."

244 Aminoddowleh, Makhzanol Vaqaye', 372.

245 Ilchi, Heyratnameh, 66.

246 Shirazi, Majmueh Safarnameha, 283.

247 Rezaqoli Mirza, Safarnameh, 515.

248 Aminoddowleh, Makhzanol Vaqaye', 351.

249 Ilchi, Heyratnameh, 127, 271.

250 Mirza Saleh expresses amazement at the size and height of the obelisk at the Hippodrome of Constantinople, indicating that no one seems to know how it could have been built and erected (Shirazi, Majmueh Safarnameha, 374). For details and images related to the choreography of moving the Vatican obelisk, see Domenico Fontana's 1590 manuscript, Della Trasportatione dell'Obelisco Vaticano.

251 Ibid., 349.

252 Mirza Saleh had previously visited a similarly large room in the Kremlin that was covered by an arch, but there he noticed how a central column supported the load (ibid., 78).

253 Ibid., 268.

254 Ilchi, Heyratnameh, 292.

255 A Persian at the Court, 258. 
256 Aminoddowleh, Makhzanol Vaqaye’, 372.

257 This association of progress with an austere simplicity in ornamentation has eerie echoes in the later writings of European modernist architects such as Louis Sullivan and Adolf Loos, who theorized that ornaments are not only unnecessary, but even criminal (see Adolf Loos, Ornament and Crime; Louis H. Sullivan, The Tall Office Building).

258 As we learn from his diary, Abolhasan was "completely overwhelmed" by the ostentatious decorations of St. Paul's Cathedral (see Plates 3 and 9) (Ilchi, $A$ Persian at the Court, 224).

259 Abolhasan mentions gold and azure decorations, marble statues, arabesques, and ebony mirrors and furniture (ibid., 62, 121, 218; Heyratnameh, 235).

260 Abolhasan expresses excitement about elaborate paintings portraying people, animals, birds, jinns, angels, and kings (Heyratnameh, 66, 123, 158, 235, 306, 344).

261 Ibid., 105, 269.

262 A Persian at the Court, 86, 194. Heyratnameh, 346.

263 "The [Cleveland] house," Abolhasan asserts, "[is] fit for a king. It is hung with Old Masters: they say that just one of them is worth 10,000 tomans" (A Persian at the Court, 194).

264 Heyratnameh, 348 (emphasis added).

265 Fraser, Narrative of a Journey into Khorasan, 152.

266 Examples include the tile works at the tomb of Shater Davani; mirror work and mosaics, calligraphy, painting, stoneworks, and wood carvings at Saadabad Garden (also known as the Mirror Palace); marble stonework and ceramic work at Shah School; mirror work on the ceiling and wall paintings in the shelves of Talar-e tavileh; cloisonné and ceiling painting in Chehel Sotun; wall paintings in Aliqapu; monabbatkari (wood carving); and minakari (vitreous enamel), paintings, and sculptures in divankhaneh (Golestan Palace) (see Shirazi, Majmueh Safarnameha, 10-14, 30).

267 Examples of Farangi ornaments that caught Mirza Saleh's attention include stoneworks in the Winter Palace, St. Petersburg; mosaics at Westminster Cathedral, London; and stained glass in Exeter Cathedral, Exeter. "On the east and west side of the cathedral," Mirza Saleh observes, "they have built two big windows, their glass was painted and baked, which looks similar to minakari. I have never seen a painting so beautiful" (ibid., 180).

268 Mirza Saleh particularly showed interest to murals in churches and palaces (ibid., 58, 78, 111, 272, 325).

269 Rezaqoli Mirza, Safarnameh, 357.

270 On their way to Windsor Palace, Fraser observes,

[the brothers] stopped to examine the beautiful church, the exquisite carved wooden work of which excited much admiration. Indeed I have remarked in more than one occasion, that this sort of ornament has attracted more notice from them than work in richer materials.

(Fraser, Narrative of the Residence, 189)

Also, when visiting the cathedral at Brussels, "the whole party were delighted," Fraser notes, "the pulpit, a rare chef-d'œuvre in carved wood, attracted great admiration. I have before observed that this style of ornament appears to suite their fancy. The beautiful painted windows too were much noticed" (ibid., 12).

271 Rezaqoli Mirza, Safarnameh, 530.

272 Rasheed el-Enany, Arab Representations of the Occident, 8.

273 Ilchi, Heyratnameh, 221.

274 Aminoddowleh, Makhzanol Vaqaye', 203. 


\section{Imagining the modern}

275 For a discussion of Abolhasan's to-the-point attitude in speaking his mind, see Green, The Love of Strangers, 10.

276 As another example, Abolhasan, who enjoyed many of the shows he had seen at the opera writes on one occasion "but tonight I did not enjoy the performance at all, and I wish that mysterious hands would appear to squeeze the breath from his throat." Elsewhere, Abolhasan comments that "English deer are ugly, with mouths like a cow's" (Ilchi, A Persian at the Court, 148, 215; Heyratnameh, 238).

277 A Persian at the Court, 235.

278 Abolhasan claims that Lord Elgin had spent 25,000 tomans to ship the ancient marble sculptures to England (ibid., 192).

279 Abolhasan criticism extends to paintings, jewelry, clothing, and parties (Heyratnameh, 164, 218, 295, 326).

280 A Persian at the Court, 137.

281 In multiple occasions, Abolhasan communicates how he finds the crowdedness, heat, and odor of indoor evening parties unpleasant, and suggested that it "could well be done away with." In his letter to the Morning Post, Abolhasan complains, "I not like such crowd in evening party every night - in cold weather not very good - now in hot weather, much too bad. I very much astonish, every day now much hot than before, evening parties much crowd than before" (Ibid., 155, 236, 239; Heyratnameh, 326. "Letter from the Persion Envoy"). Note that some scholars rightfully suspect whether the letter was written by Abolhasan.

282 Heyratnameh, 150, 156, 160, 194, 218, 295, 326. A Persian at the Court, 208, 292.

283 Fraser, Narrative of a Journey into Khorasan, 152.

284 Ilchi, Heyratnameh, 234, 235.

285 Abolhasan complained that the streets and bazaar adjacent to the customs office were not as clean as the ones across the park (ibid., 293).

286 A Persian at the Court, 237.

287 Aminoddowleh, Makhzanol Vaqaye', 395.

288 Ibid., 334.

289 An example of Mirza Saleh's impartial representation is evident in his description of Moscow's built environment. "Some of the buildings," Mirza Saleh explains, "lack order and symmetry. In a street, for example, two houses that are big and beautiful sit next to five ugly ones. ... Some streets are wide, paved, and clean and others are narrow and filthy" (Shirazi, Majmueh Safarnameha, 78).

290 Ibid., 18, 20, 21, 25.

291 Ibid., 309.

292 Aside from a few exceptions, Rezaqoli maintains a positive attitude even in non-Farangi cities. One exception is Galatz, where according to Rezaqoli, "is the most disgusting place in the world. The people are stuck in so much garbage, they cannot escape the abundance of filth. I am astonished how they can live here, for it is the abode of hell" (Rezaqoli Mirza, Safarnameh, 676).

293 Ibid., 527. Interestingly, Abolhasan had come to a similar conclusion. "Unlike other nations, whose people conceal their fortune," Abolhasan writes that English people "exhibit their wealth" (Ilchi, Heyratnameh, 348).

294 Rezaqoli Mirza, Safarnameh, 576.

295 Fraser, Narrative of the Residence, 273.

296 For example, see Rezaqoli's disapproving reaction to a negative comment about the quality of water in London (Rezaqoli Mirza, Safarnameh, 671).

297 Fraser, Narrative of the Residence, 284.

298 Ibid., 176.

299 Rezaqoli Mirza, Safarnameh, 372. See also ibid., 513.

300 Note that Fraser was a romantic and a naturalist, and he likely had his own reasons for casting aspersions on city life. 
301 During their tour of Europe, several of the travelers had visited major industrial cities such as Manchester, England and Lille, France.

302 Friedrich Engels, The Condition of the Working-Class in England in 1844, 54-73.

\section{References}

Aminoddowleh, Farrokh-Khan. Makhzanol Vaqaye': Safarnameh-Ye Farrokh Khan-e Aminoddowleh [Aminoddowleh's Travelogue]. Majmu'eh Safarnameha-Ye Irani. 2nd ed. Tehran: Asatir, 1994.

Ayati, Abdolhosein. Atashkadeh-Ye Yazdan. Yazd: Golbahar, 1938.

Cloake, Margaret Morris. "Foreword and Footnotes." Translated by Margaret Morris Cloake. In A Persian at the Court of King George: The Journal of Mirza Abul Hassan Khan. London: Barrie \& Jenkins Ltd, 1988, 7-12.

Editorial. "Darolkhelafeh Tehran.” Vaghaye Ettefaghiyeh, December 121851.

-. "Hamedan." Vaghaye Ettefaghiyeh, July 61853.

el-Enany, Rasheed. Arab Representations of the Occident: East-West Encounters in Arabic Fiction. Culture and Civilization in the Middle East. London, New York: Routledge, 2006.

Engels, Friedrich. The Condition of the Working-Class in England in 1844. Stanford, Oxford, London: Stanford University Press, Basil Blackwell and Allen and Unwin, 1958.

Fraser, James Baillie. Narrative of a Journey into Khorasan, in the Years 1821 and 1822 Including Some Account of the Countries to the North-East of Persia; with Remarks Upon the National Character, Government, and Resources of That Kingdom. London: Longman Hurst Rees Orme Brown and Green, 1825.

- Narrative of the Residence of the Persian Princes in London, in 1835 and 1836. The Middle East Collection. New York: Arno Press, 1973.

Ghanoonparvar, M. R. In a Persian Mirror: Images of the West and Westerners in Iranian Fiction. 1st ed. Austin: University of Texas Press, 1993.

Gibson, James J. The Senses Considered as Perceptual Systems. Boston: Houghton Mifflin, 1966.

Green, Nile. The Love of Strangers: What Six Muslim Students Learned in Jane Austen's London. Princeton, NJ: Princeton University Press, 2015.

Habibi, Mohsen. Az Shar Ta Shahr. 4th ed. Tehran: University of Tehran, 2003.

Hafez. "Poetry of Hafiz Translated by Shahriar Shahriari." http://www.hafizonlove. com/divan/06/254.htm.

Ilchi, Abolhasan. Heyratnameh: Safarnameh-Ye Mirza Aolhasan Khan-e Ilchi Beh Landan [Wonderlogue: The Accounts of Ambassador Abolhasan Khan's Travel to London]. 1st ed. Tehran: Moasseseh-ye Khadamat-e Farhangi-ye Rasa, 1986.

- A Persian at the Court of King George: The Journal of Mirza Abul Hassan Khan. Translated by Margaret Morris Cloake. London: Barrie \& Jenkins Ltd, 1988. Koolhaas, Rem. "Bigness and the Problem of Large." In $S, M, L, X l$, edited by Rem Koolhaas and Bruce Man, 494-516. New York: Monacelli Press, 1995.

Kracauer, Siegfried, and Thomas Y. Levin. The Mass Ornament: Weimar Essays. Cambridge, MA: Harvard University Press, 1995.

"Letter from the Persion Envoy, Mirza Abul Hassan." The Morning Post, May 29 1810.

Loos, Adolf. Ornament and Crime: Selected Essays. Studies in Austrian Literature, Culture, and Thought Translation Series. Riverside, CA: Ariadne Press, 1998. 


\section{Imagining the modern}

Lynch, Kevin. The Image of the City. Publications of the Joint Center for Urban Studies. Cambridge, MA: Technology Press, 1960.

Mitchell, Timothy. "The World as Exhibition." Comparative Studies in Society and History 31, no. 2 (1989): 217-236.

Momtahenoddowleh, Mahdi Khan. Khaterat-e Momtahenoddowleh: ZendegiNameh-e Mirza Mahdi Khan Momtahenoddowleh Shaqaqi. Tehran: Amir Kabir, 1974.

Morier, James Justinian. A Journey through Persia, Armenia, and Asia Minor, to Constantinople, in the Years 1808 and 1809: In Which Is Included, Some Account of the Proceedings of His Majesty's Mission, under Sir Harford Jones . . . To the Court of the King of Persia. London: Printed for Longman, Hurst, Rees, Orme, and Brown ... 1812.

Necipoğlu, Gülru. "Framing the Gaze in Ottoman, Safavid, and Mughal Palaces." Ars Orientalis 23 (1993): 39.

Rezaqoli Mirza. Journal of a Residence in England, and of a Journey from and to Syria, of Their Royal Highnesses Reeza Koolee Meerza, Najaf Koolee Meerza, and Taymoor Meerza, of Persia, to Which Are Prefixed Some Particulars Respecting Modern Persia, and the Death of the Late Shah. Translated by As'ad Yakub Khayyat. London, Westmead: W. Tyler, Gregg Inter., 1839.

- Safarnameh-Ye Rezaqoli Mirza Navey-Ye Fath Ali Shah [the Travel Account of Rezaqoli Mirza, Fath Ali Shah's Grandson]. Majmueh Safarnameha-Ye Irani. Edited by Asghar Farmanfarmai Qajar. 3rd ed. Tehran: Asatir, 1994.

Shirazi, Mirza Saleh. Majmueh Safarnameha-Ye Mirza Saleh Shirazi [Series of Travelogues by Mirza Saleh Shirazi]. Nashr-e Tarikh-e Iran. 1st ed. Tehran: Nashr-e Tarikh-e Iran, 1985.

Sullivan, Louis H. The Tall Office Building Artistically Considered [in English]. Minneapolis: University of Minnesota Press, 1922.

Tabatabai, Javad. Ta'ammoli Dar Bareh-Ye Iran: Nazariyyeh-Ye Hokumat-e Ghanun Dar Iran [Theory of Constitutional Governance in Iran] [in Persian.]. 2nd ed. Tehran: Intisharat-e Sotudeh, 2008.

Tavakoli-Targhi, Mohamad. Refashioning Iran: Orientalism, Occidentalism, and Historiography. St. Antony's Series. New York: Palgrave, 2001.

—. "Tajaddod-e Ruzmarreh Va Ampul-e Tadayyon [Everyday Modernity and Religious Inoculation].” Iran Nameh XXIV, no. 4 (2009): 37.

Vahdat, Vahid. "Spatial Discrimination in Tehran's Modern Urban Planning 19061979." Journal of Planning History 12, no. 1 (2013): 49-62.

- "A Study on Urban Development in Iran from 1925 to 1941, Case Study: Yazd [in Persian].” Journal of Honar-ha-ye-ziba no. 31 (2007): 5-14.

Vitruvius, Pollio. Vitruvius: The Ten Books on Architecture. New York: Dover Publications, 1960.

Wulff, Hans E. “The Qanats of Iran.” Scientific American 218, no. 4 (1968): 9. 


\section{$5 \quad$ Tajaddod as a discourse}

Consider, too, that I have stolen naught

In any library; and while our verse

Is of the Orient, I have not sought

To prate of that. You'll find the tale no worse;

The East is vast and far! Great wonders rise

From memory, and travel dims the eyes.

$$
\text { -Alfred de Musset, "Namouna"1 }
$$

\section{League of extraordinary gentlemen}

Throughout this book I have mentioned in passing the interrelated nature of the travel accounts, showing for example how certain phrases (such as "wide, paved, and clean") are echoed from one author to another, and how the travelers, though speaking in their individual voices, nonetheless detailed remarkably similar visions of the Farangi ideal. In this concluding chapter I will take a closer look at the underlying discursive network that informed the authors' perspectives and retrospectively helped shape a vision for the future. This discourse was strongly grounded in the elite Persian social circles to which the travelers belonged, and it was also based in the established literary patterns of the safarnameh genre in which they wrote. Although direct references to other travelogues are absent in the diaries, the authors demonstrate a clear genre awareness. Abolhasan's diary, for example, as one scholar shows, "borrows ... from the classical Arabic travel literature of ribla." More specifically, both the title and the introduction of his book are greatly influenced by a late eighteenth-century travel account by Mirza Etesamoddin. ${ }^{3}$

By examining the interconnections among the travelers, a complex web of personal and ideological relationships can be seen - one that helps us to better understand how the memoirs contributed to the emerging discourse of Iranian modernity. These men, who came from similar backgrounds, traveled to the same places, toured the same buildings, engaged the same European hosts, and aspired to the same utopian future, were not merely 
isolated commentators. They should be regarded as active participants in an ongoing discussion.

To begin unraveling this discursive nexus we can first consider interactions among the travelers, making note of their familiarity and their shared social circles. Abolhasan's journey was the earliest of the four and can thus provide a starting point. The ruler of Iran, Fathali Shah (r. 1797-1834), sent Abolhasan to England in 1809 with an explicit mandate to help secure British support in the ongoing Perso-Russian wars. While this trip was the occasion of the memoir studied here, it did not mark the end of Abolhasan's travels, nor of his participation in affairs of state. Just a few years later, in 1815, Abolhasan was sent to St. Petersburg to help negotiate with the Russian regime for the return of occupied Iranian territories. ${ }^{4}$ While in St. Petersburg he met with a group of Persian students who were just beginning their trip into Europe to pursue educational opportunities in Farangestan. One of these students was named Mirza Saleh. In his memoir, Mirza Saleh mentions Abolhasan a few times and describes how they spent an evening together at a theater in St. Petersburg and also met later in London. ${ }^{5}$

Mirza Saleh's excursion included other notable Iranian youths, such as Hajibaba Afshar, who would later join Mirza Saleh on additional trips. It was also sponsored by important state officials, such as Mirza Mas'ud Mostowfi, who later replaced Abolhasan as the Iranian foreign minister. ${ }^{6}$ The ongoing relationships among these individuals can be seen in the case of another 1829 diplomatic mission to Russia. Abolhasan was originally slated to lead this trip, but he made excuses to avoid it. As a replacement, Fathali Shah's grandson, Khosrow Mirza (who was also Rezaqoli's cousin), was assigned to lead the diplomatic envoy. ${ }^{7} \mathrm{He}$ was joined by Mirza Saleh, as well as the aforementioned Hajibaba Afshar and Mirza Mas'ud Mostowfi. ${ }^{8}$ Another member of this 1829 expedition was Amir Kabir, who twenty years later would become Iran's chief minister and a noted modern reformer. ${ }^{9}$

Just prior to Fathali Shah's death in 1834, he sent Abolhasan as part of a delegation to Fars, Iran. The purpose of this team was to secure longoverdue taxes from the powerful governor of Fars, Hoseyn-Ali Farmanfarma, who was a member of the extended royal family and was also Rezaqoli's father. ${ }^{10}$ The Shah's death put an end to this mission and threw the country's politics into turmoil. Eventually, one of Fathali's grandsons, Mohammad Shah (r. 1834-1848), defeated his rivals and became the new ruler. He did so at the expense of his brother, Khosrow Mirza, who was mentioned earlier as the leader of Mirza Saleh's Russian expedition, and at the expense of his uncle Farmanfarma. After Farmanfarma was imprisoned by the new regime, Rezaqoli and his brothers fled to England.

In 1838, the new Mohammad Shah and his foreign minister, Abolhasan, decided to send a mission to England. The person assigned to lead this trip was named Hoseyn Khan Ajudanbashi, ${ }^{11}$ and a significant part of his mandate was to communicate Iran's disapproval of the British government's harboring of three fugitive princes - Rezaqoli and his brothers. Ajudanbashi's secretary kept an account of this journey under the title Ajudanbashi's 
Mission, though this travelogue is not included as part of the current study. ${ }^{12}$ Upon his return to Iran, Ajudanbashi became the governor of Yazd and later the governor of Fars. He was eventually forced out of office and jailed by Mirza Saleh's previous companion, the reformer Amir Kabir. ${ }^{13}$

In addition to these complex personal relationships among the travelers and their Persian peers, the writers also shared a common connection with a handful of influential British commentators. The nature of these relationships differed among the travelers. Abolhasan's cooperation with British authorities had a political aspect for which he received a handsome pension, whereas Mirza Saleh collaborated in scholarly endeavors where his contributions were seldom even acknowledged. ${ }^{14}$ Nevertheless, their British contacts consisted of a small and consistent circle. Three British hosts are particularly notable and have been mentioned throughout this book: James Justinian Morier (1780-1849), Sir Gore Ouseley (1770-1844), and James Baillie Fraser (1783-1856). Interestingly, it is these same three individuals that George Curzon later indicated as shaping the parameters of British Orientalism in relation to Iran; "[a few commentators] have for so long formed the basis of English ideas about Persia, viz., Morier, Ouseley, and Fraser."15 However, for the purposes of this study, the importance of these British contacts is not so much the ideas they disseminated about Iran in England, but rather in the way in which their elite status, diplomatic positioning, and personal interests mediated a certain image of modern Europe for the travelers, thereby contributing to the vision of Farangestan.

Morier first visited Iran in 1808 as a secretary to the British envoy. On his way to Tehran, he was received by the governor of Fars, Hoseyn-Ali Farmanfarma. Morier writes that the governor had eight children at the time but he does not specifically mention meeting Rezaqoli and his brother during his stay in Shiraz. ${ }^{16}$ Upon his return to England in the same year, he was accompanied by the Iranian ambassador, Abolhasan. The two remained in close contact while Abolhasan was in London, and Morier accompanied Abolhasan on his return journey back to Iran in 1810. Morier is noted not only for his diplomatic activities, but also for his famous picaresque novel, The Adventures of Hajii Baba of Ispahan. ${ }^{17}$ While much of the characterization of "Hajji Baba" can be traced to Morier's protracted association with Abolhasan, the name of the main character in this novel was taken from Mirza Saleh's companion, the aforementioned Hajibaba Afshar, whom Morier also met in England. Afshar was quite displeased with the deliberate abuse of his name for the vain, ignorant, and foolish character. ${ }^{18}$ In his travelogue Mirza Saleh also reports that Morier, as the British secretary of embassy in Iran, sent multiple memoranda to the English government insisting that the students had been sent to England without his permission. These letters caused quite a bit of difficulty for Mirza Saleh and his friends in pursuing their studies. ${ }^{19}$

Ouseley, a noted Orientalist and diplomat, was appointed as the official host of Abolhasan during his stay in England. He was also designated as Britain's "ambassador extraordinary and plenipotentiary" to the Persian 
court, in which capacity he accompanied Morier, Abolhasan, and their retinue in their return from London to Iran. Ouseley also joined Abolhasan in his later mission to Russia and played an important role in the negotiations that led to the 1813 Treaty of Golestan between Iran and Russia. ${ }^{20}$ Mirza Saleh met with Ouseley on multiple occasions during his stay in England, and later collaborated with him and his brother, William, in studies on Iran. ${ }^{21} \mathrm{~A}$ few years later, Mirza Saleh served as a guide for a British delegation to Iran which included both Ouseley and Morier. ${ }^{22}$ Rezaqoli and his brothers also had contact with Ouseley during their stay in England and attended multiple events at Ouseley's house. ${ }^{23}$ Three years later Ouseley met with Ajudanbashi, who communicated Iran's dissatisfaction with the British government's reception of the brothers. ${ }^{24}$

Fraser had greater artistic and adventurous aspirations in comparison to the other British contacts. He came to Iran in 1821 and spent two years traveling through the northwestern regions of the country. During his Persian travels Fraser came into contact with Abolhasan, whom he described as "mean and dishonest." ${ }^{25}$ In later years Fraser was appointed as an escort officer for Rezaqoli and his brothers during their stay in London, and he accompanied them on their return to Baghdad in $1836 .{ }^{26}$ In 1839, Fraser was again called to act as host to Ajudanbashi.

Not mentioned in this narrative is Farrokh-Khan, who occupied a different historical position due to the transitions that took place during Naseraddin Shah's assumption of power. While Farrokh-Khan may not be as closely tied to the other travelers, who visited Europe two to four decades before him, and although he was connected to a different social circle of elites, he is nevertheless part of the same discursive pattern. This network of interactions brought coherence and clarity to the otherwise fragmented perceptions about Farangi progress. The social construction of Iran's experience of modernity (tajaddod), deals principally not with its correspondence with European modernity, but with the internal consistency of long-harbored expectations about Farangestan. The constellation of such aspirations laid the groundwork for a vision of progress that would grow in influence during the following century.

To understand how the discursively shaped ideals reflected in the safarnamehs eventually contributed to a full-blown indigenous experience of Iranian modernity, it is useful to consider the history and meaning of the term that is most often used to describe that modernity: tajaddod. Scholars disagree on when exactly the concept of tajaddod first appeared in Persian literature. Abbas Amanat, an expert on Iranian modernity, suggested to me through personal correspondence that the term "entered Persian modernist vocabulary via the Ottoman Empire perhaps during the Constitutional era." ${ }^{27}$ Jamshid Behnam has likewise argued that the concept originated in the Ottoman Empire, though in other contexts he has attributed its primary spread to the Persian Sheikh Mohammad Khiyabani, who founded a newspaper named Tajaddod in Iran in 1917. ${ }^{28}$ Although it not known 
exactly when or where this Arabic word was first adopted into the Persian language, most scholars indicate that it became popular around the late nineteenth and early twentieth centuries to describe a new forward-looking social project. ${ }^{29}$

This conventional dating of Iranian tajaddod near the turn of the century is why it is so striking to see Rezaqoli, in 1836, writing of "nehzate tajaddod-khabi," which literally means "the tajaddod-ist movement." 30 In this passage Rezaqoli is describing the public desire for reform that he encountered when traveling in the Ottoman Empire, and the corresponding changes implemented by the Ottoman ruler Mahmud II (r. 1808-1839). It is probable that Rezaqoli first heard the word during his stay in Istanbul. His interest in the concept, however, and his application of it using the Persian suffix "khahi" (meaning desire/demand), seems to be among the very first written expressions of tajaddod in the Persian language. Thus, while the scholarship that traces tajaddod to the Ottomans seems accurate, the chronology of its transition into Iran may be earlier than was previously believed. Furthermore, at least one of the means of transmission of this term and the related ideas was through the literary format of the travel diaries and the utopian ideals that they conveyed.

Tajaddod is an Arabic loan-word that was adopted into Persian; however, it is not the Arabic word for modernity. In Arabic, hadatha is used to signify modernity. This brings up some interesting questions: what exactly does tajaddod mean, and why did this term emerge to represent a particular vision and social movement in Iran? The most literal English rendering of tajaddod is in fact, "renewal." The word "changement," transcribed from French, was used an interchangeable alternative for tajaddod by the leading figures of the Mashruteh movement. ${ }^{31}$ As other scholars have noted before me, the nineteenth-century understanding of Iranian modernity was about both change and renewal. ${ }^{32}$ In a similar fashion, the current generation of Iranian scholars, who aim to replace Arabic loan-words with Persian equivalents, have constructed concepts such as nogeraei and novaregi as alternatives to tajaddod. ${ }^{33}$ Both of these terms connote "renewal" in their translations of modernity. While almost two centuries have passed since the concept of tajaddod was first introduced, its discursive formation still influences our contemporary understanding of modernity.

This study appreciates travel writing as a mode of transferring architectural ideas. As such, the journey to Farangestan is a departure from the preexisting self, but it is also an arrival at a pre-imagined Other. Through their utopian visions and sense of wonder, the travelers discussed in this book are not conveying a slavish adoption of modern European trends. Instead, the discourse expressed in the memoirs needs to be understood as sui generis, a unique and particular blending that emerged in a specific historical and geographic moment while feeding from centuries of collectively shaped ideals. 


\section{Building the future}

The image of a progressive Farangestan, as I have demonstrated throughout this book, is a social construction that, besides the actual architectural setting that the travelers examined, employs preconceived imagery. This imagery is partly informed by the travelers' shared spatial desires, such as their anti-urban fantasies of heavenly gardens and fountain streams. The spatial material that the travelers chose to report in their diaries shows a pattern of selectiveness, fueled by an apparent confirmation bias. In other words, the travelers demonstrate a tendency to seek facts that confirm their ideas about Farangestan and ignore evidence that refutes its overall coherence. The wondrous Occident serves as a canvas on which the travelers could fill the blanks, recolor the scenes, and paint their utopian vistas. This utopian imagery thus finds a hybrid quality that is best represented in the travelers' attempts to domesticate the Farangi space. Fraser informs us of a scene shortly after Rezaqoli's brother arrived in London:

[The prince] began to gaze about him with new interest. "Ah! che khoob jaee," said he, as we passed Primrose-Hill, "what a fine place is this! This is something like, now; this reminds me of Persia. There I would just wish to wander about or ride on that sahra." ${ }^{34}$

As Farangestan functioned like a canvas for self-projection, hosting the travelers' aspirations and hopes for the future, it was also a mirror for selfreflection, through which they could identify their fears. Tajaddod was in part a result of a pathological reflection on the backward condition of Iran, which had come into focus especially after the war with Russia. Likewise, the construction of modern architecture in Iran was partially a reaction to the state of its built environment. The spatial qualities that the travelers celebrate are often based in a contrast and perhaps a slight hostility to the contemporaneous everyday Iranian environment. To the travelers, haphazard development, introverted houses, organic orders of construction, curved and narrow streets, and even the use of mud-brick materials are all signs of social backwardness. In contrast, the travel diaries present a longing for greater planning, architectural regulation, structural firmness in construction, and the institution of order and cleanliness in the city.

A closer investigation of these characteristics reveals a fundamentally elitist vision of social progress, which is perhaps best represented in the travelers' desire for large-scale construction, grand urban projects, topdown planning, hierarchical procession of space, and spatial segregation. Naturally, the visions described in the memoirs differ slightly based on each traveler's individual background and personality. Mirza Saleh, in particular, had fewer aristocratic ties than the others, and perhaps unsurprisingly he evinces a much greater interest in social services and the experiences of European commoners. All of the travelers, however, could be considered members of the social elite, and their perspectives were shaped by specific 
class and gender discourses. They were all learned men who could employ their literary skills, religious training, familiarity with Persian classic poetry, and acquaintance with Iran's power structure as a means of advancing their agenda and swaying their audience.

Had the discourse of Farangi progress been introduced to Iran through the lower classes, tajaddod might have been very different. While Abolhasan, Rezaqoli, and Farrokh-Khan were all attended by a number of servants during their travels, the descriptions of the servants' outlooks must be regarded as heavily mediated by the authors' prejudices. The diaries uniformly portray the Persian laborers as lazy, cowardly, ignorant, and superstitious, with a complete lack of self-control when it comes to stealing, drinking, and sleeping with prostitutes. The writers indicate a clear embarrassment that such inferior people might be seen as representing Persian culture to the Farangi gaze.

To the extent that the perspectives of the servants can be identified in the memoirs, they seem to share the same admiration for cleanliness and technological marvels as did their masters ${ }^{35}$ and to be equally selective in evaluating Farangi objects. ${ }^{36}$ While they were quick to learn European customs ${ }^{37}$ they felt no shame in practicing their contextually foreign habits, and thereby domesticating Farangi space. ${ }^{38}$ The servants tended to evaluate these experiences from a more direct "user" point of view, rather than from an idealistic vision. At the Royal Hospital at Greenwich Abolhasan reports, "I hear my servants talking among themselves. One of them, who is particularly lazy, said he would like to live here with the old people - they lead such tranquil lives, he thought it unlikely they would ever die!" 39 The servants were also particularly impressed by the modest manner with which the nobility in Farangestan mingle with women and the lower classes, and wished that "this attitude becomes customary in our country as well." ${ }^{40}$

Being less attached to the traditions and cultures that had positioned them in the lower levels of the social structure, the servants showed higher motivation to embrace modernity, even at the expense of "a separation" from their domestic ties. Perhaps unsurprisingly, a number of the servants who accompanied these authors on their journeys made arrangements to depart from their positions when it became possible. While several of Abolhasan's servants, as Morier reports, "would willingly have remained in England," his cook finally managed to decamp in Istanbul, an abdication that Abolhasan attributed to the servant's dislike of sailing. ${ }^{41}$ Several servants in Rezaqoli's retinues also made attempts to stay behind and find employment in London as their masters prepared to return to Iran..$^{42}$ His tailor, for example, had planned his lodging, found an employer, and even negotiated "good wages," as Fraser reports. ${ }^{43}$

Unlike their unfortunate servants, who had limited say on even personal matters, the authors of the travelogues had the leverage to promote their vision in literature and to pursue their Farangi ideal through large-scale projects and political activities after their return to Iran. Concrete elements of this legacy can be seen in the edifices that they sponsored or constructed, 
such as the personal residences of Abolhasan and Farrokh-Khan. Several visitors left a record of the unique syncretic architectural elements in Abolhasan's house, including "chairs for those English gentlemen who visit him." ${ }^{44}$ The British consul William Richard Holmes describes the apartment as being "very nicely fitted up in somewhat of an European style." ${ }^{45}$ Fraser's more detailed portrait of the house indicates how European embellishments were included within a decidedly luxurious and indigenous aesthetic:

[Abolhasan] received us in a sort of boudoir, highly ornamented with English prints and mirrors, French clocks, and other gimcracks, among which was placed, in a conspicuous situation, a picture of himself by a Russian artist. A comfortable carpet with numuds as usual covered the floor, but there was also an excellent fire blazing in a European grate; and the whole had much more comfort than is usually to be met with in Persian apartments.... He showed us his whole ménage, and by its arrangement, it was sufficiently apparent that he had picked up some idea of convenience, as well as other good things in England; he did not however approve completely of the plan of our English house; he thought them deficient in ground space, and that the rooms were much too small. ${ }^{46}$

As mentioned previously, Farrokh-Khan constructed his house in Kashan, Iran, to the height of three stories. Unfortunately, the house was later demolished, and I have not been able to locate any detailed descriptions of its attributes. One existing record of Farrokh-Khan's quarters in Tehran, however, indicates that: "He received us in an upper room, the ceiling of which was covered with pictures of fair women, while the walls were tastefully adorned with glass, with many facets and enamel." 47

Of all the travelers, Farrokh-Khan contributed most directly to Iran's architectural legacy. In addition to the projects he initiated as the minister of the interior, such as his street paving efforts (discussed in chapter four), he supervised the construction of Iran's most celebrated bazaar. The edifice is in Farrokh-Khan Aminoddowleh's hometown, Kashan, and is named after him: Timcheh-ye Aminoddowleh. Reflecting Farrokh-Khan's interest in architectural grandeur and strength, it is the largest bazaar in Iran and deviates significantly from contemporaneous styles in its dynamism, materiality, and grandiosity. ${ }^{48}$ While the building is adorned with multiple murals, which is rather unprecedented in the bazaar typology, it is nothing like a European import, as it strongly reflects the aesthetics and symbolism of local traditions of architecture (see Plate 15). Apparently, FarrokhKhan had also funded construction in the bazaar of Tehran. His interest in commercial typology seems to have grown during his trip to Europe. There, Farrokh-Khan mentions a "wise, intelligent, insightful, and knowledgeable merchant" telling him, "No progress happens in any nation unless by the efforts of businessmen." 49 In his conversation with Napoleon III, the emperor made a similar comment by linking commercial interactions to international strength. ${ }^{50}$ 


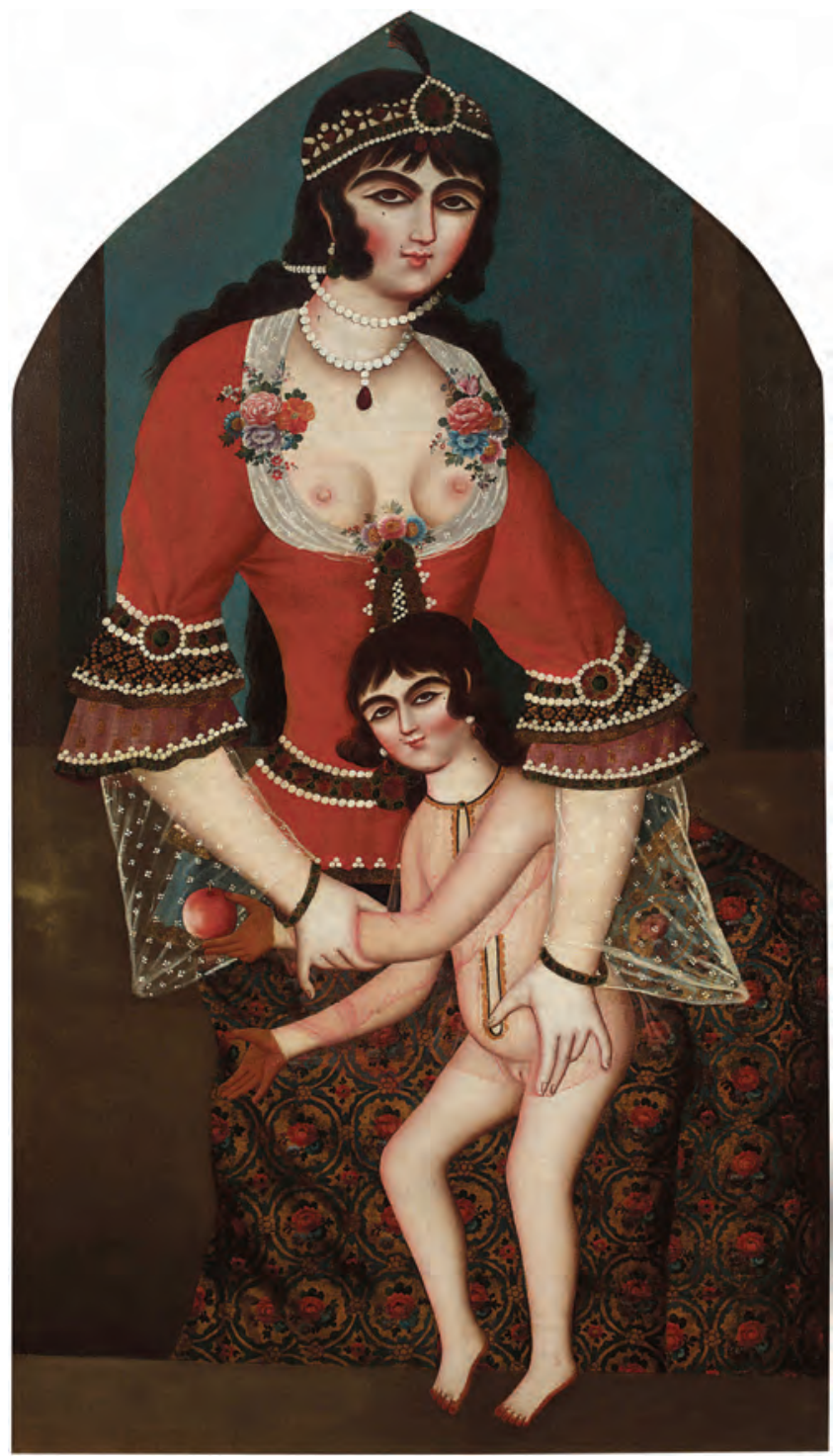

Plate 1 Mother and child, attributed to Muhammad Hasan, second or third decade of the 19th century.

Source: Private collection, Monaco (courtesy of Sotheby's Auction House). 


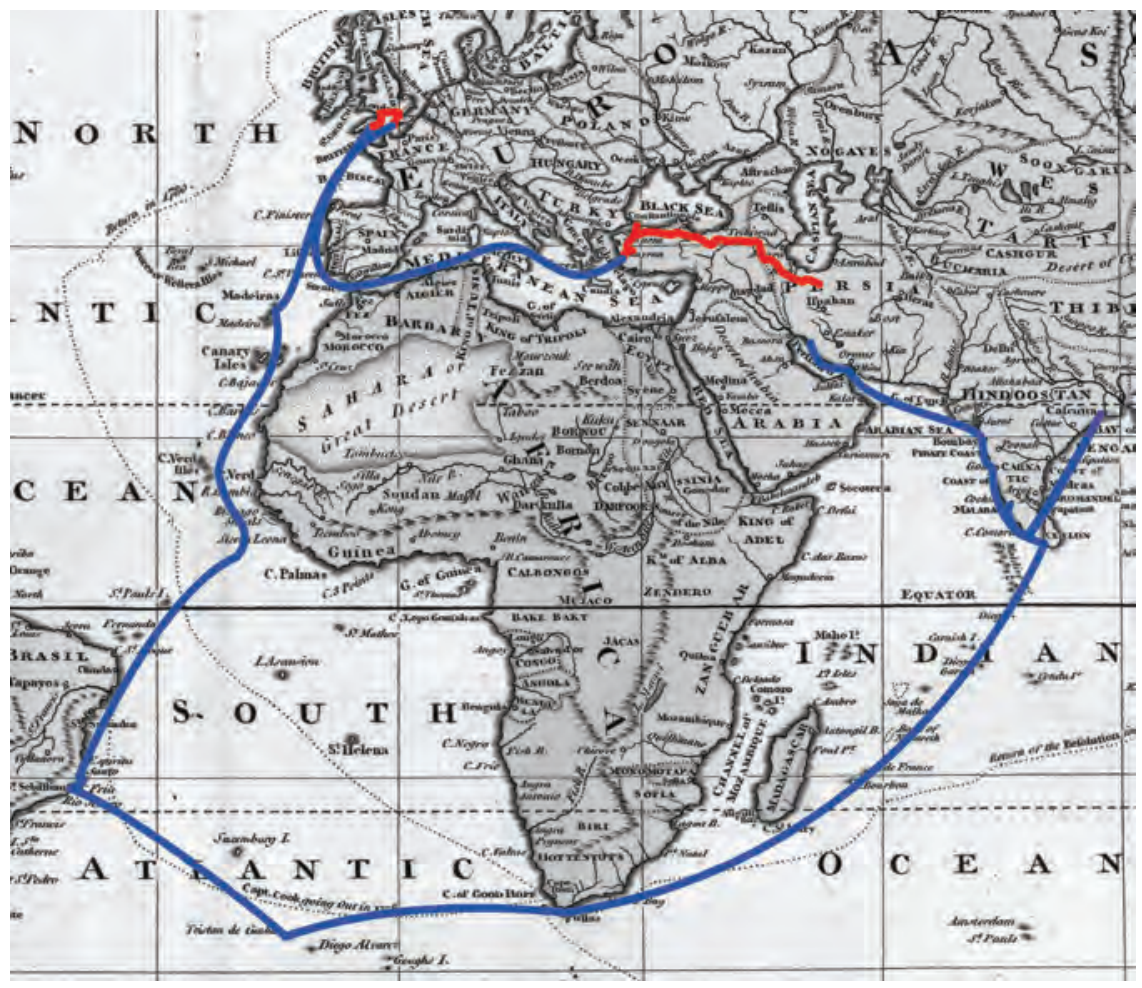

Plate 2 An 1800 map showing Abolhasan's course of travel. The blue lines show sea routes and the red lines show land trips.

Source for Map: David Rumsey Map Collection. 


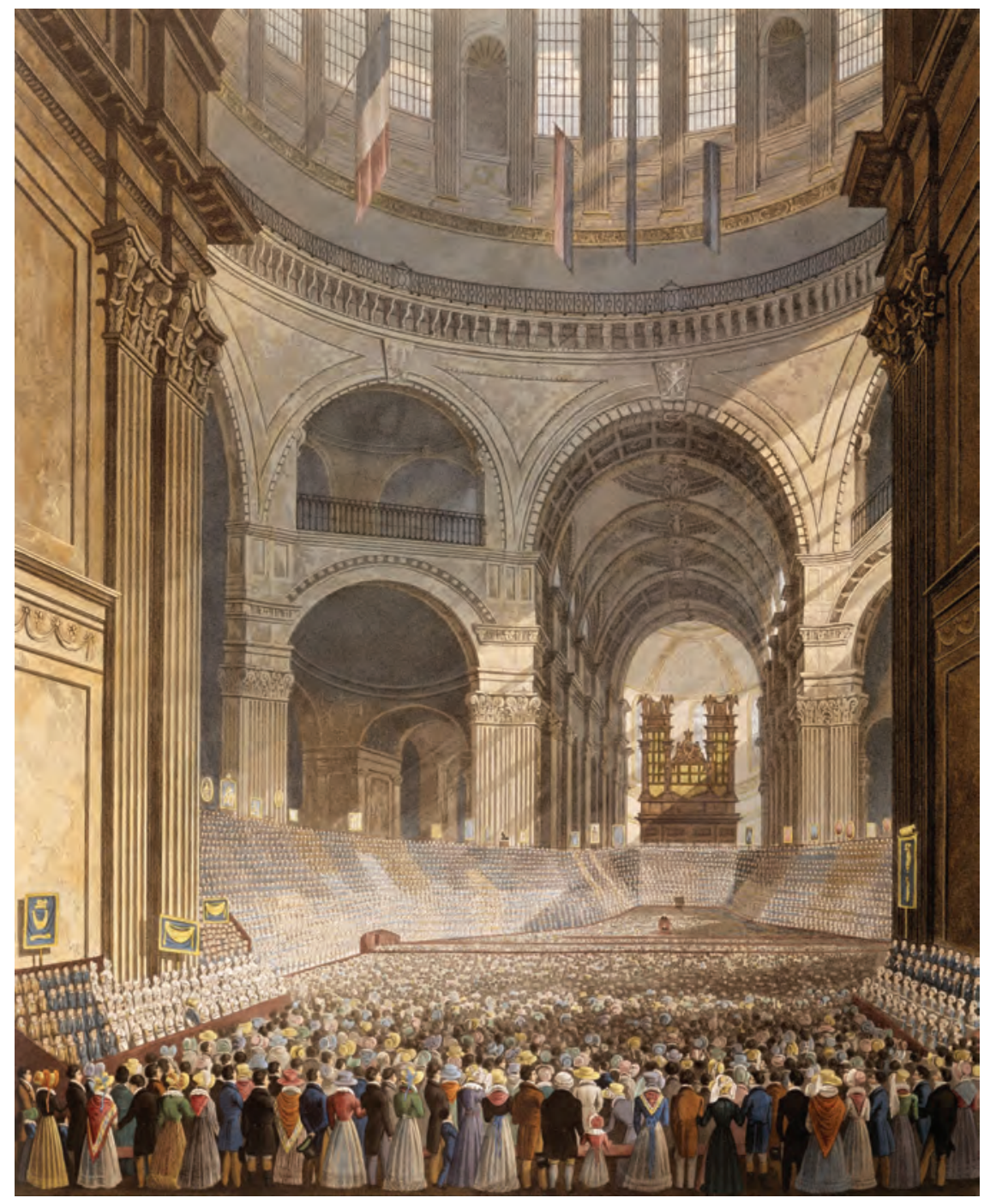

Plate 3 The Anniversary Meeting of the Charity Children in the Cathedral of St. Paul, painted by Robert Havell, Jr. in 1826.

Source: Museum of London. 


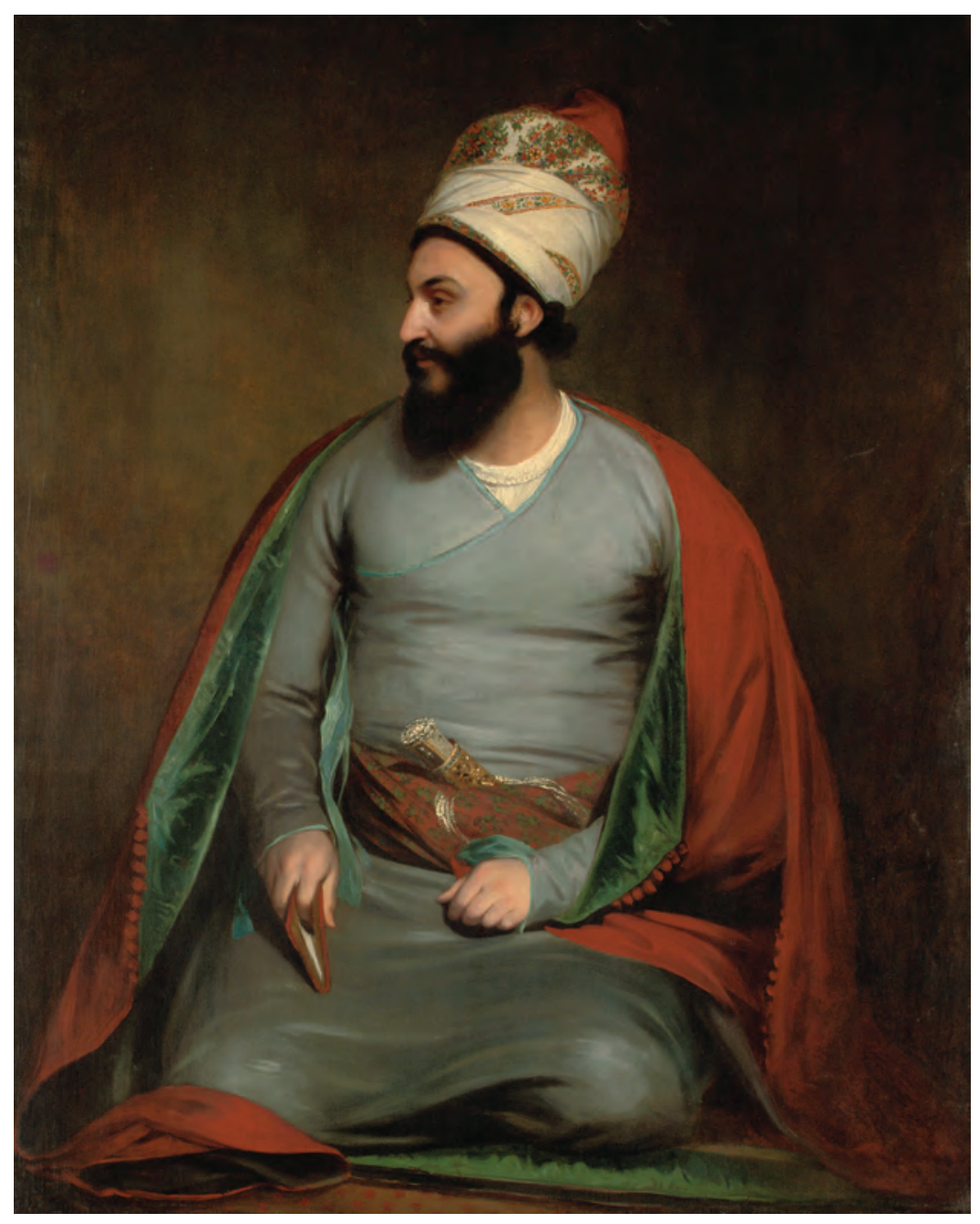

Plate 4 Mirza Abu'l Hassan Khan (Abolhasan) holding a book, painting by Sir William Beechey. (c) 2006 Christie’s Images Limited. 


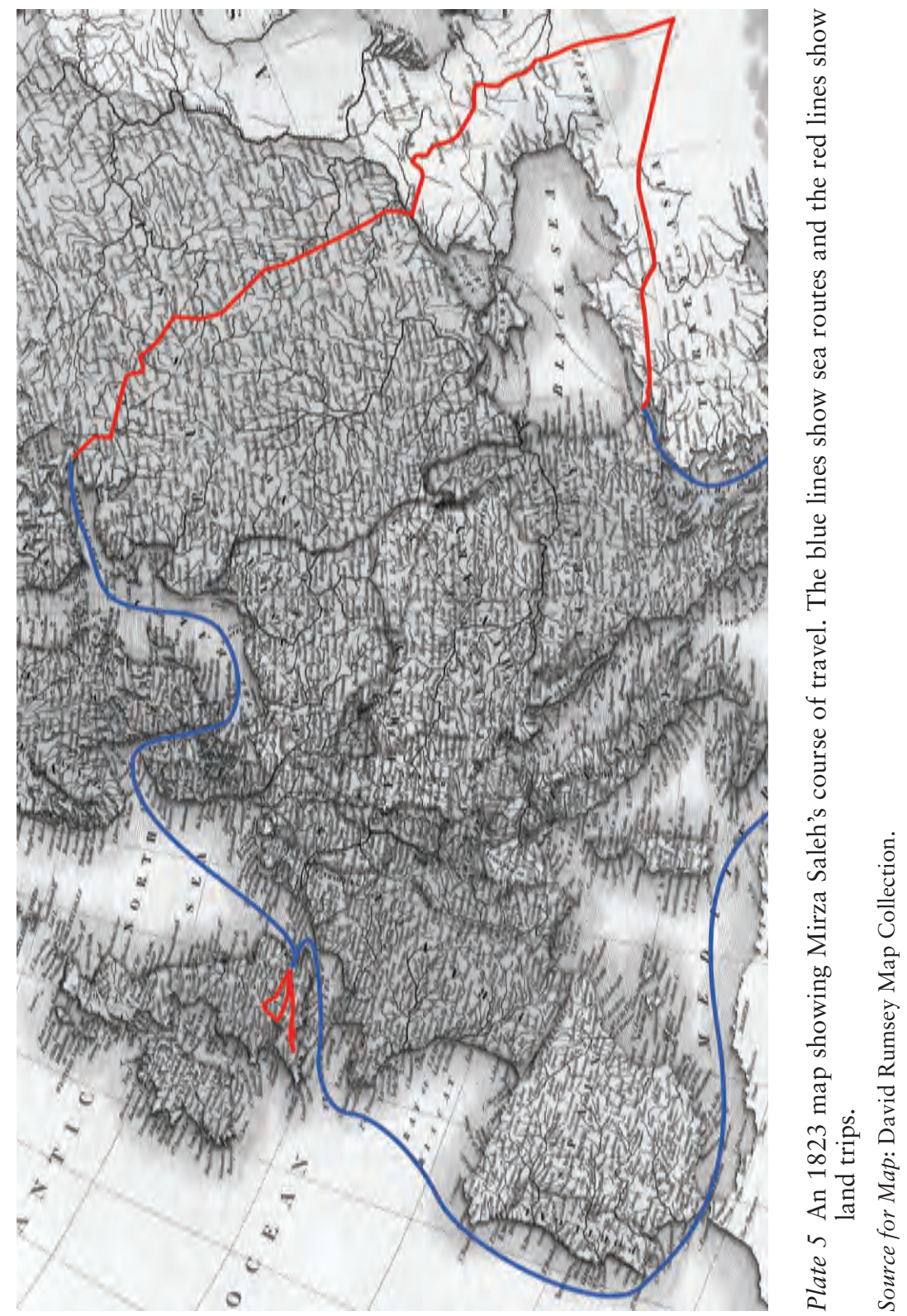




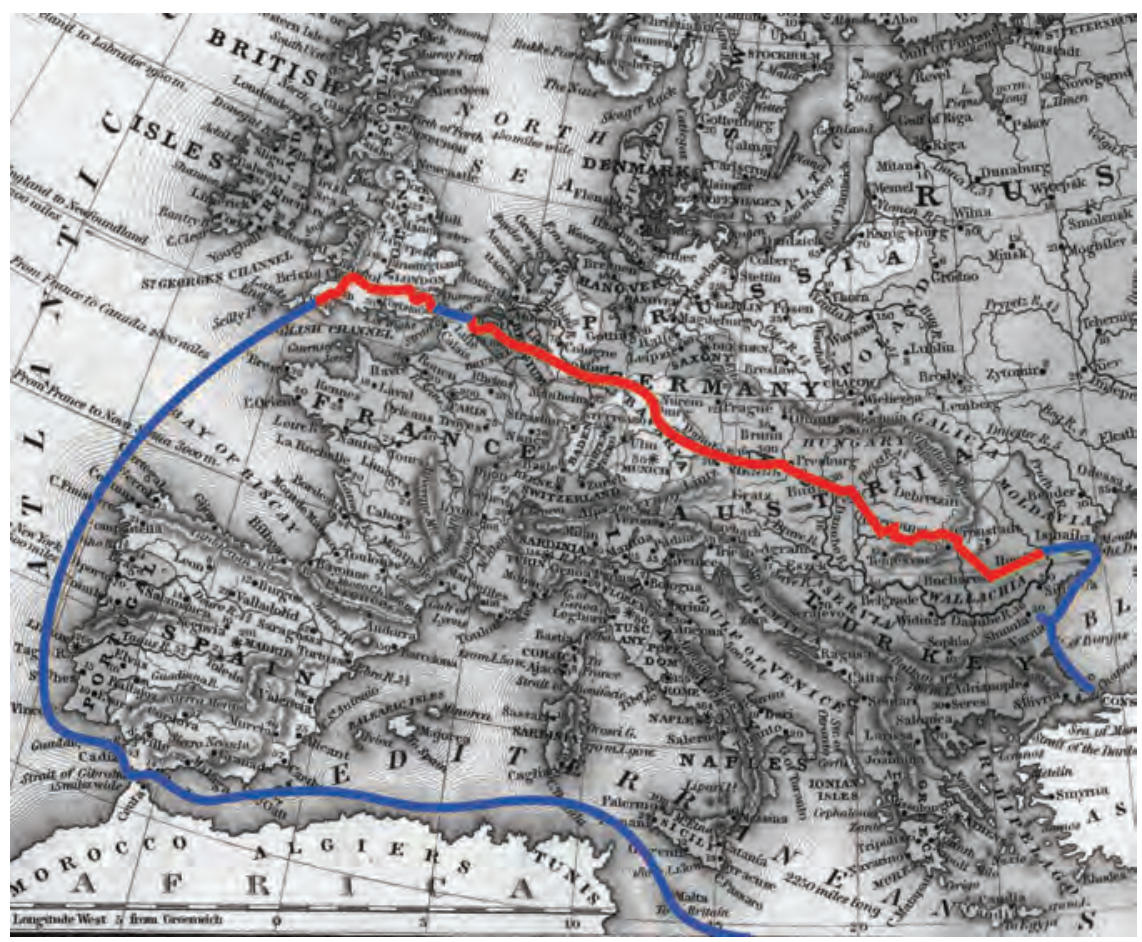

Plate 6 An 1839 map showing Rezaqoli's course of travel. The blue lines show sea routes and the red lines show land trips.

Source for Map: David Rumsey Map Collection. 


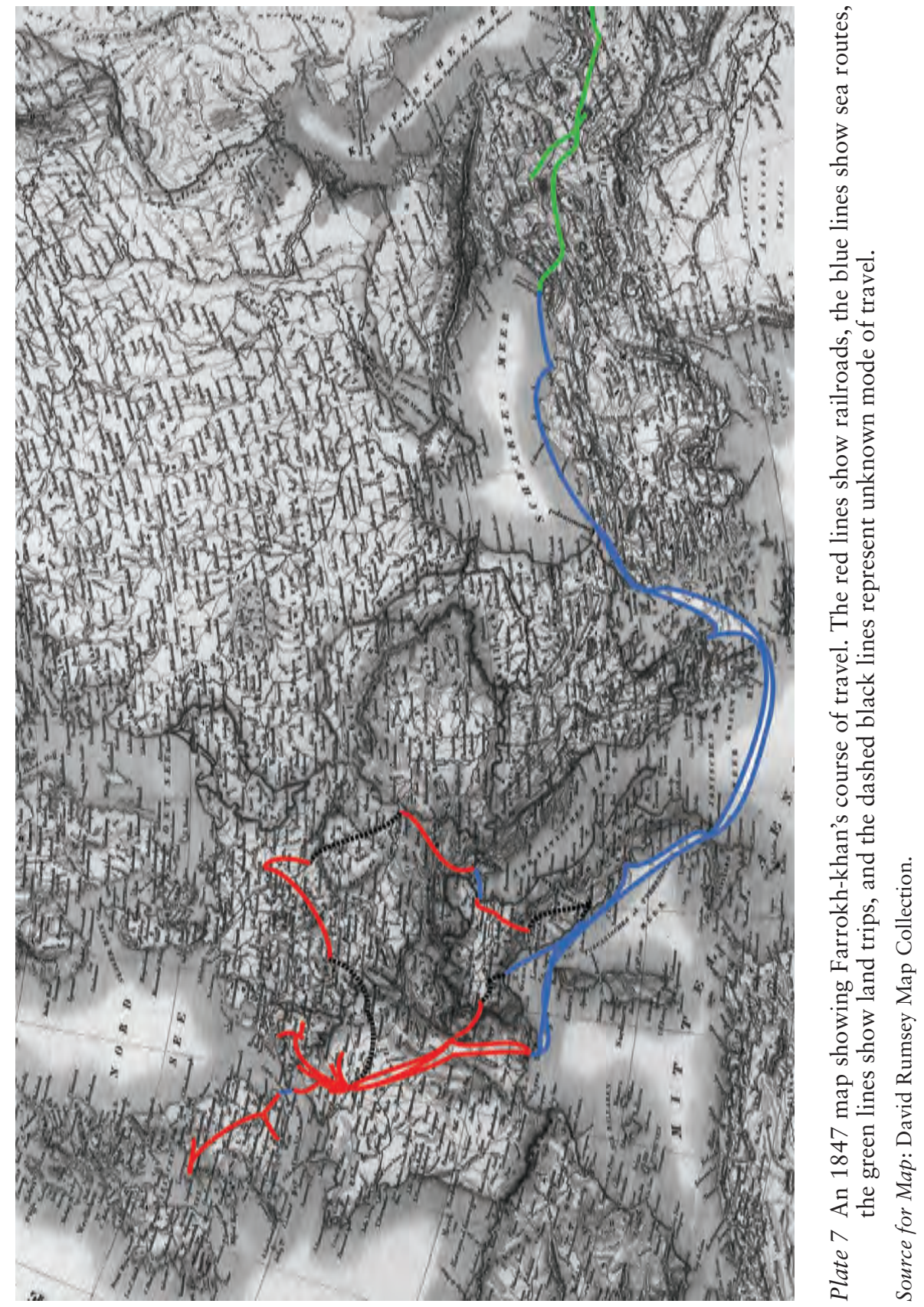




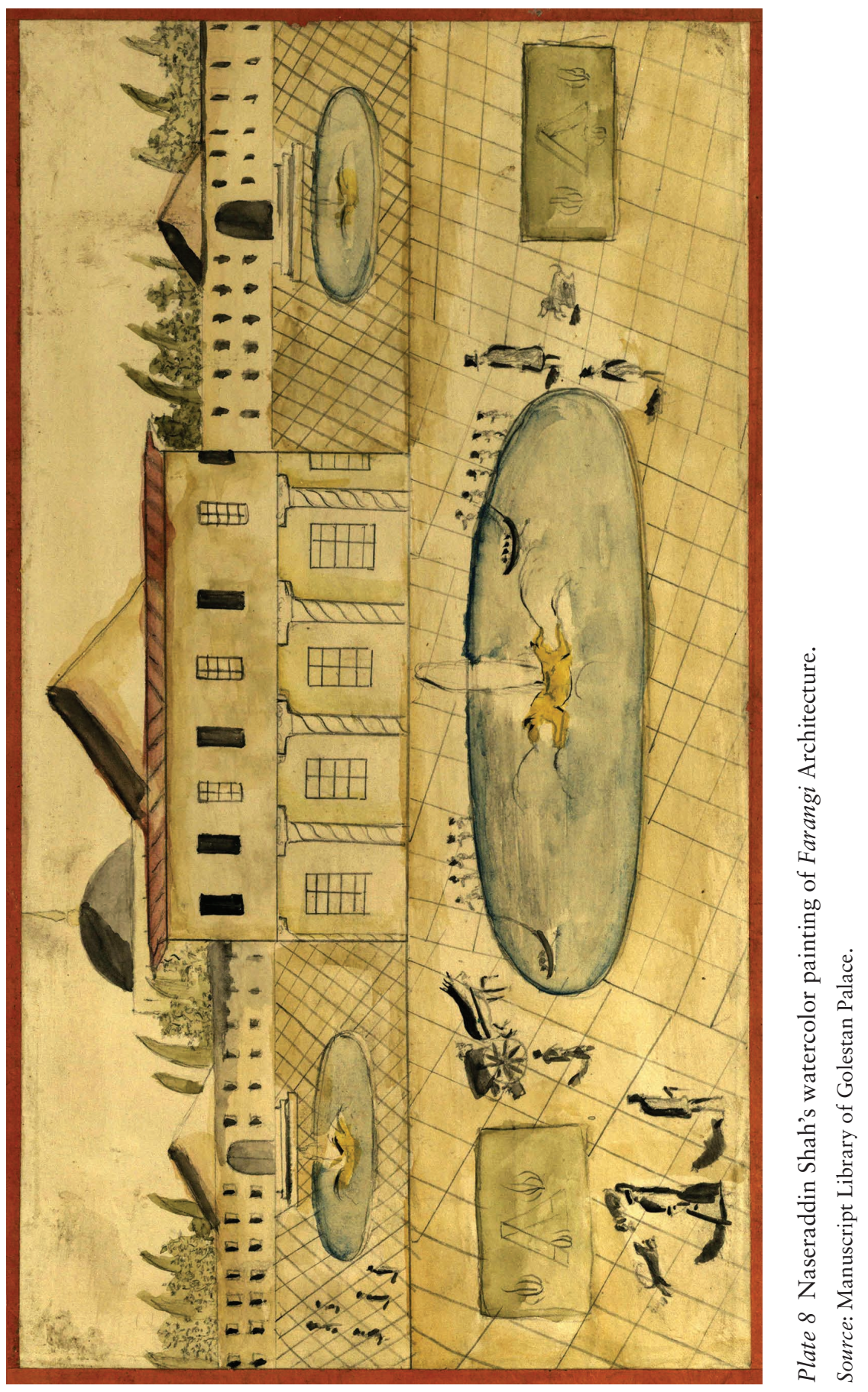



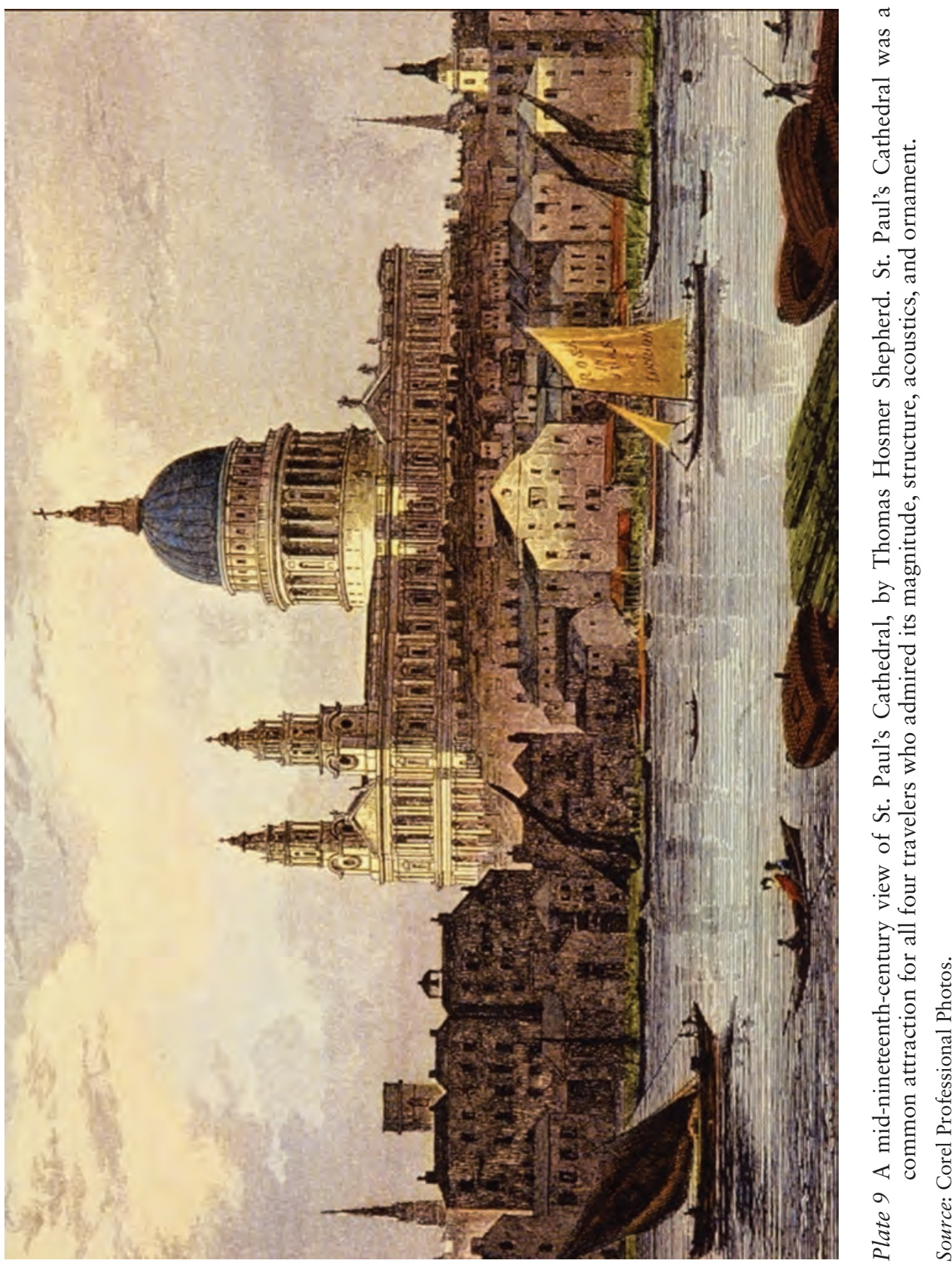


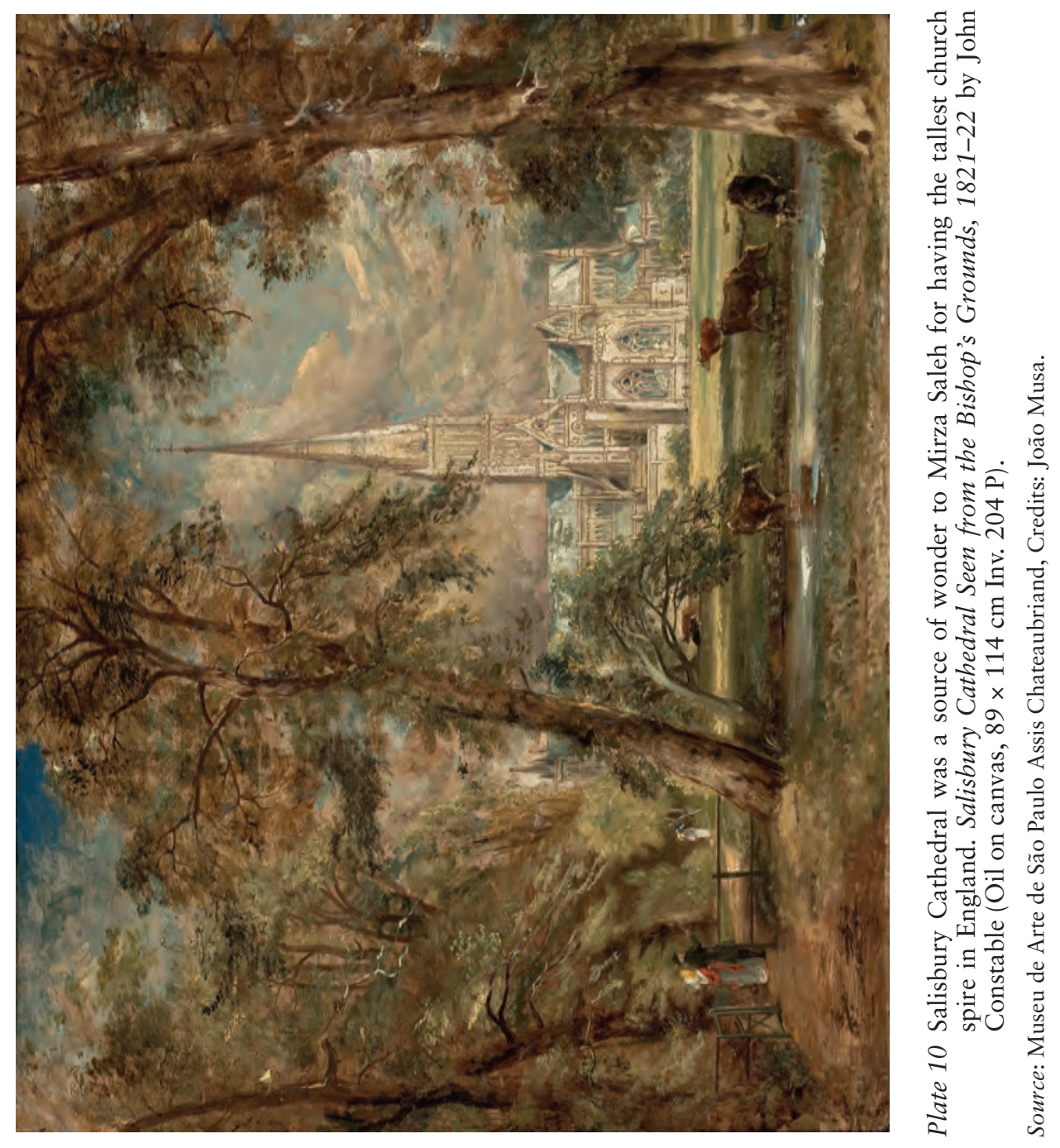



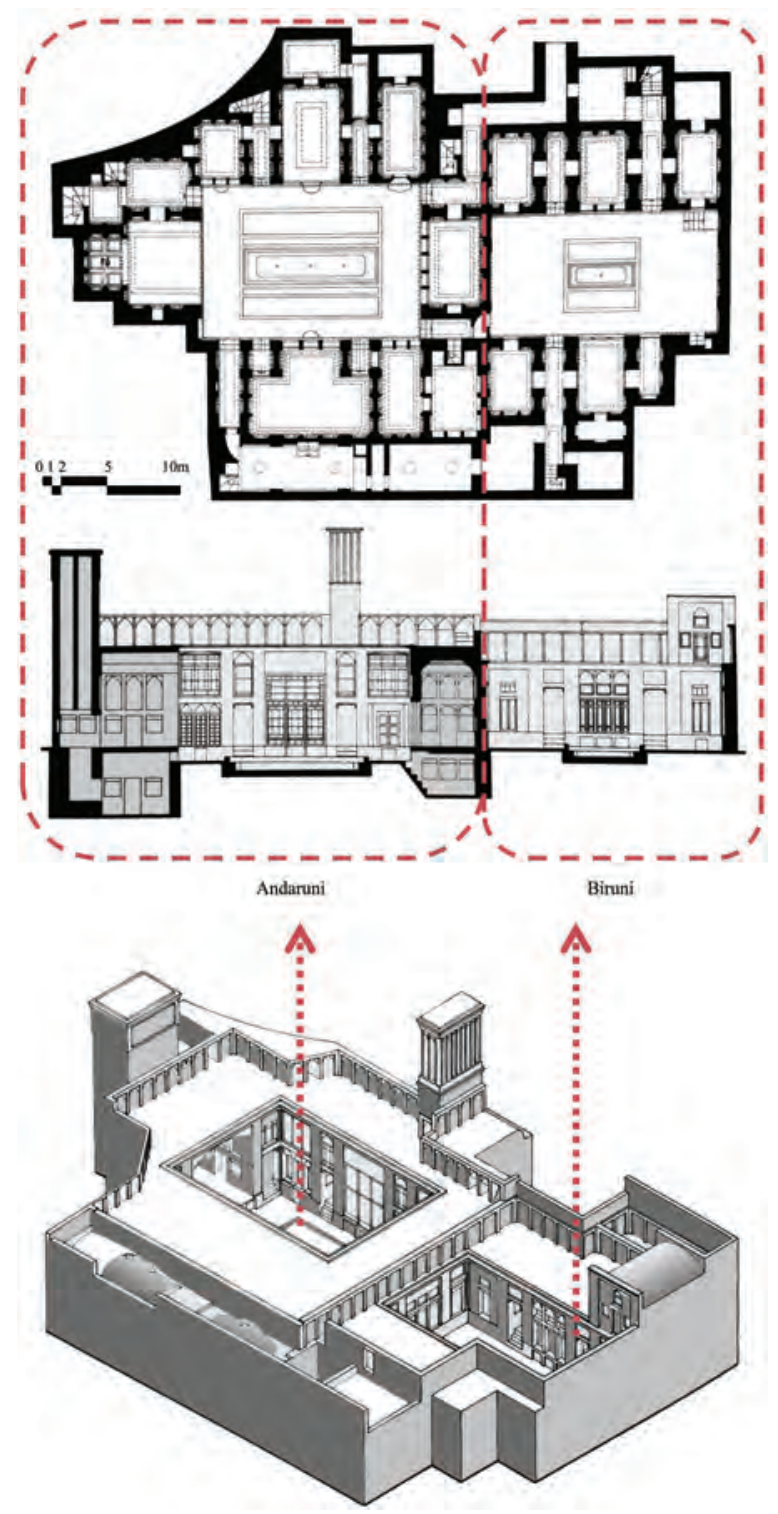

Plate 11 Example of public/private divisions and central interior courtyards in Persian architecture. Gerami House, Yazd, Iran.

Source: Kambiz Hajighasemi's 2004 Ganjnameh, Document Center of Shahid Beheshti University. 

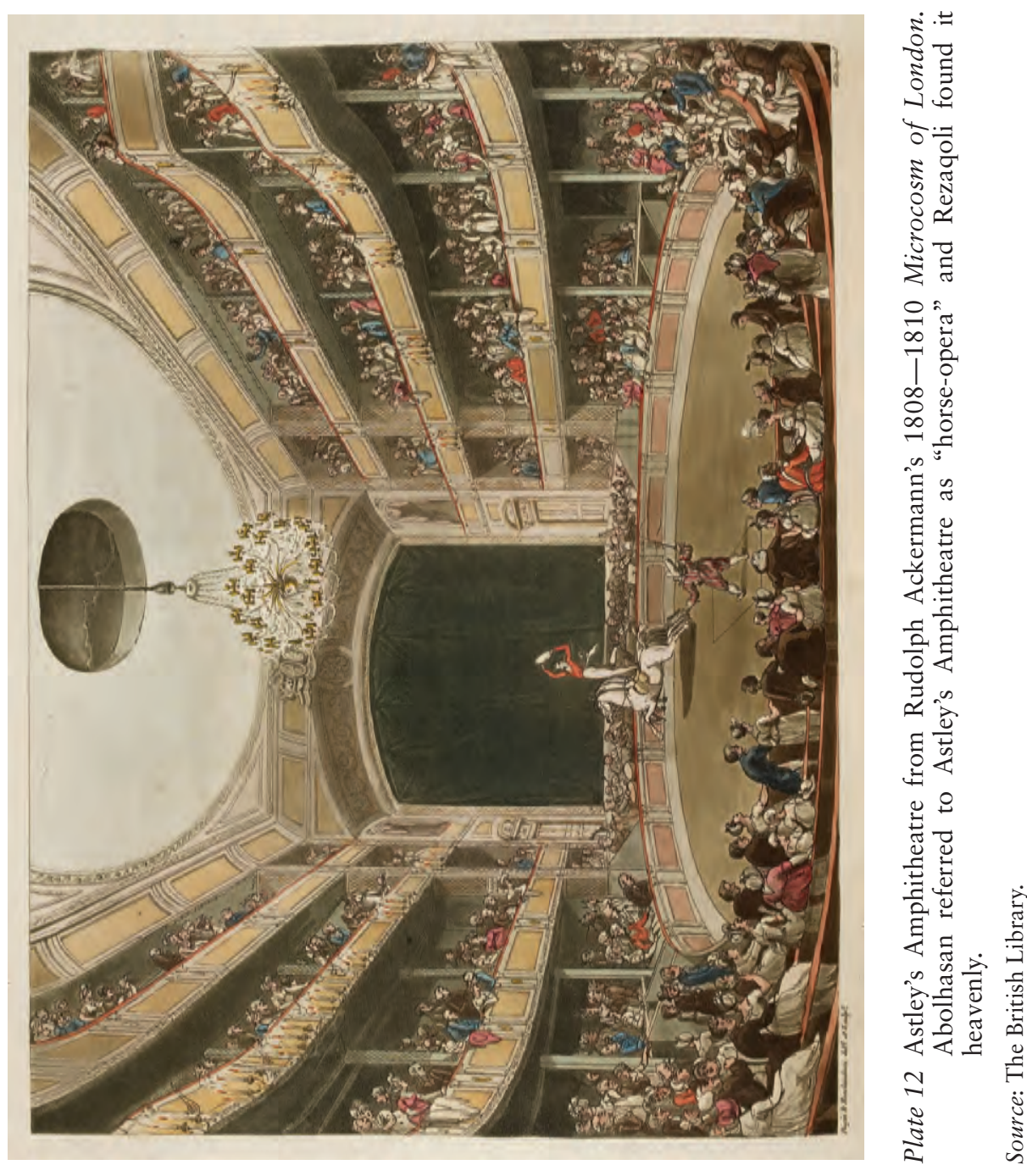

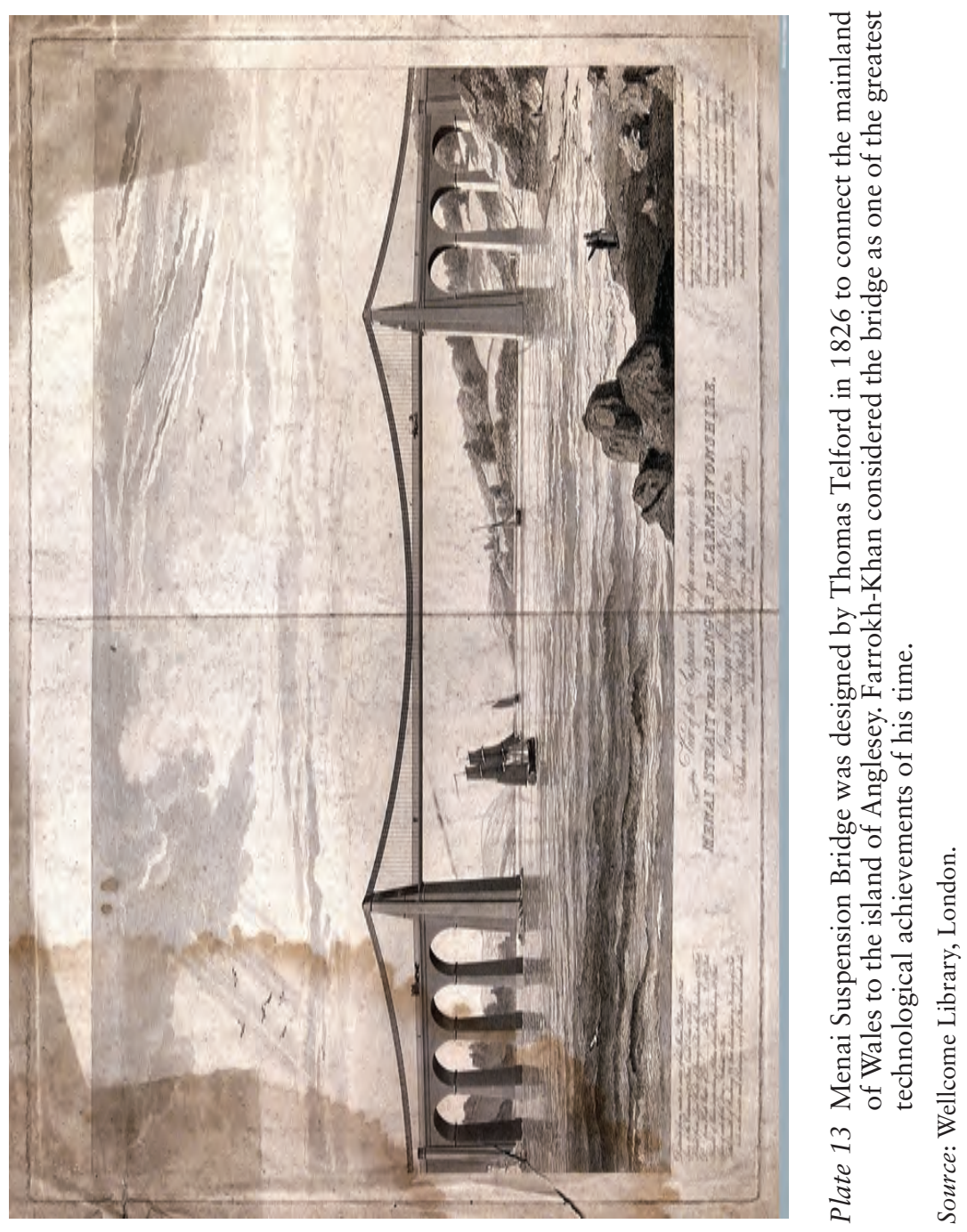


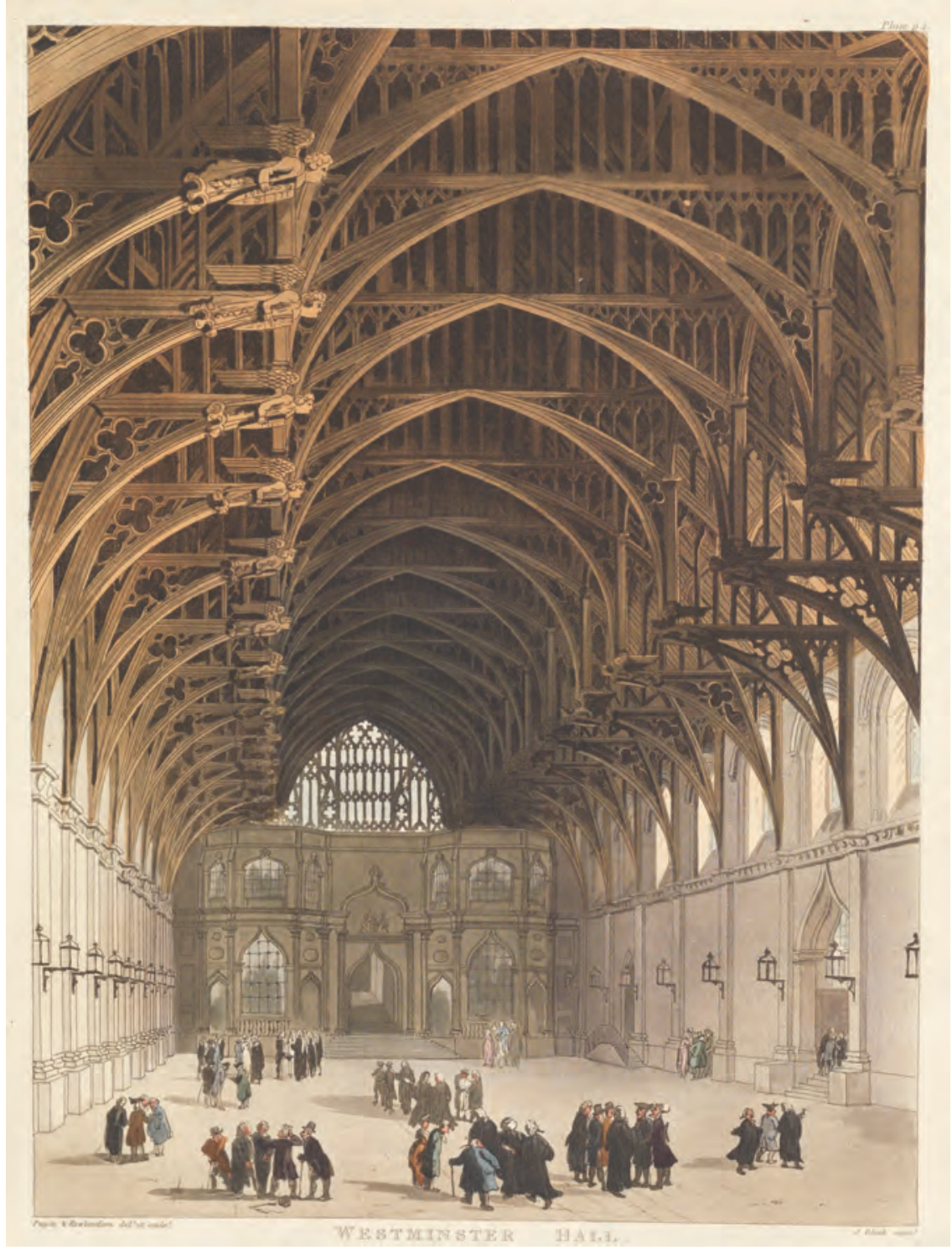

Plate 14 Westminster Hall in London by Augustus Pugin. Mirza Saleh found the absence of central supporting columns in the building to be a curious and inexplicable wonder.

Courtesy of The Lewis Walpole Library, Yale University. 


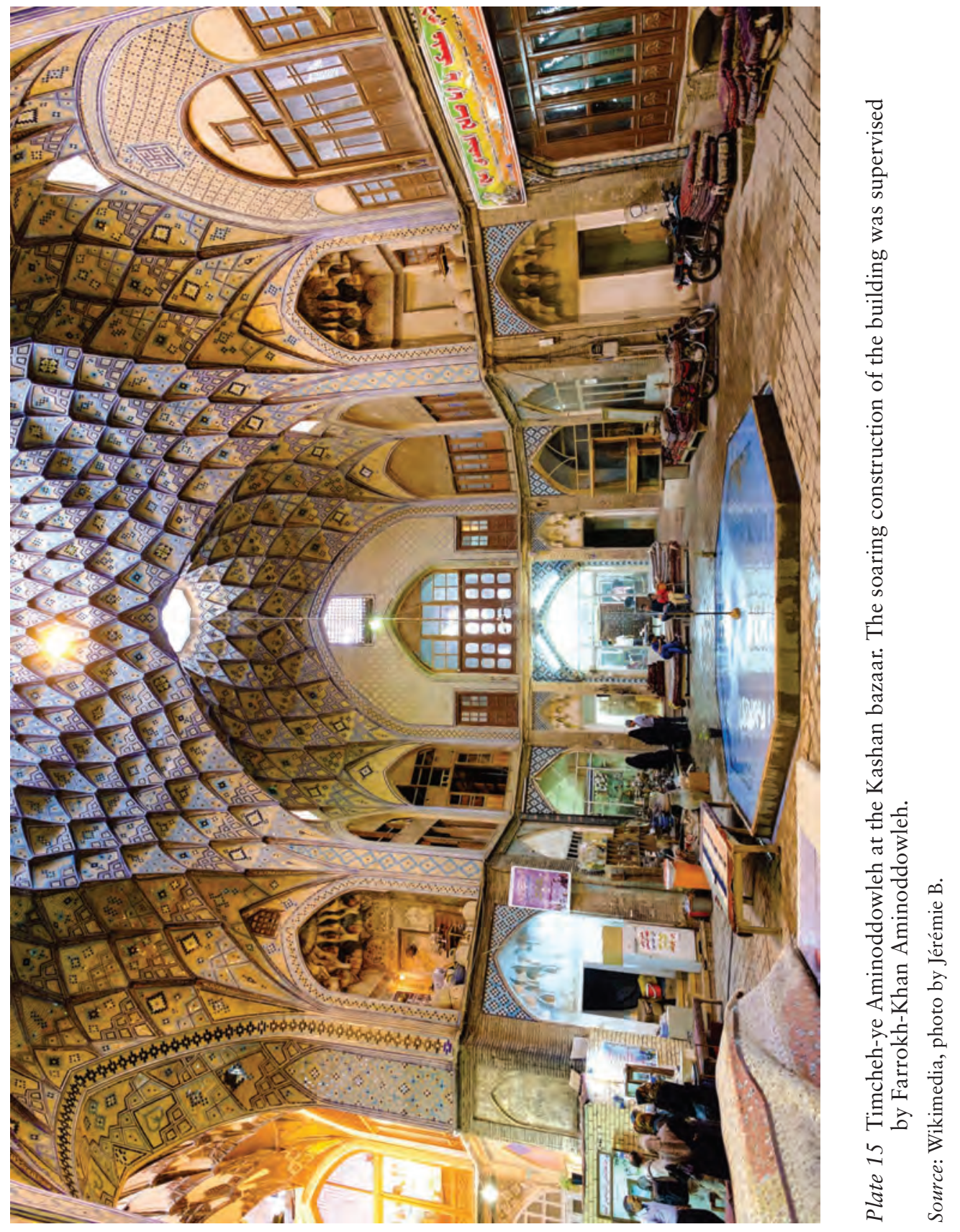




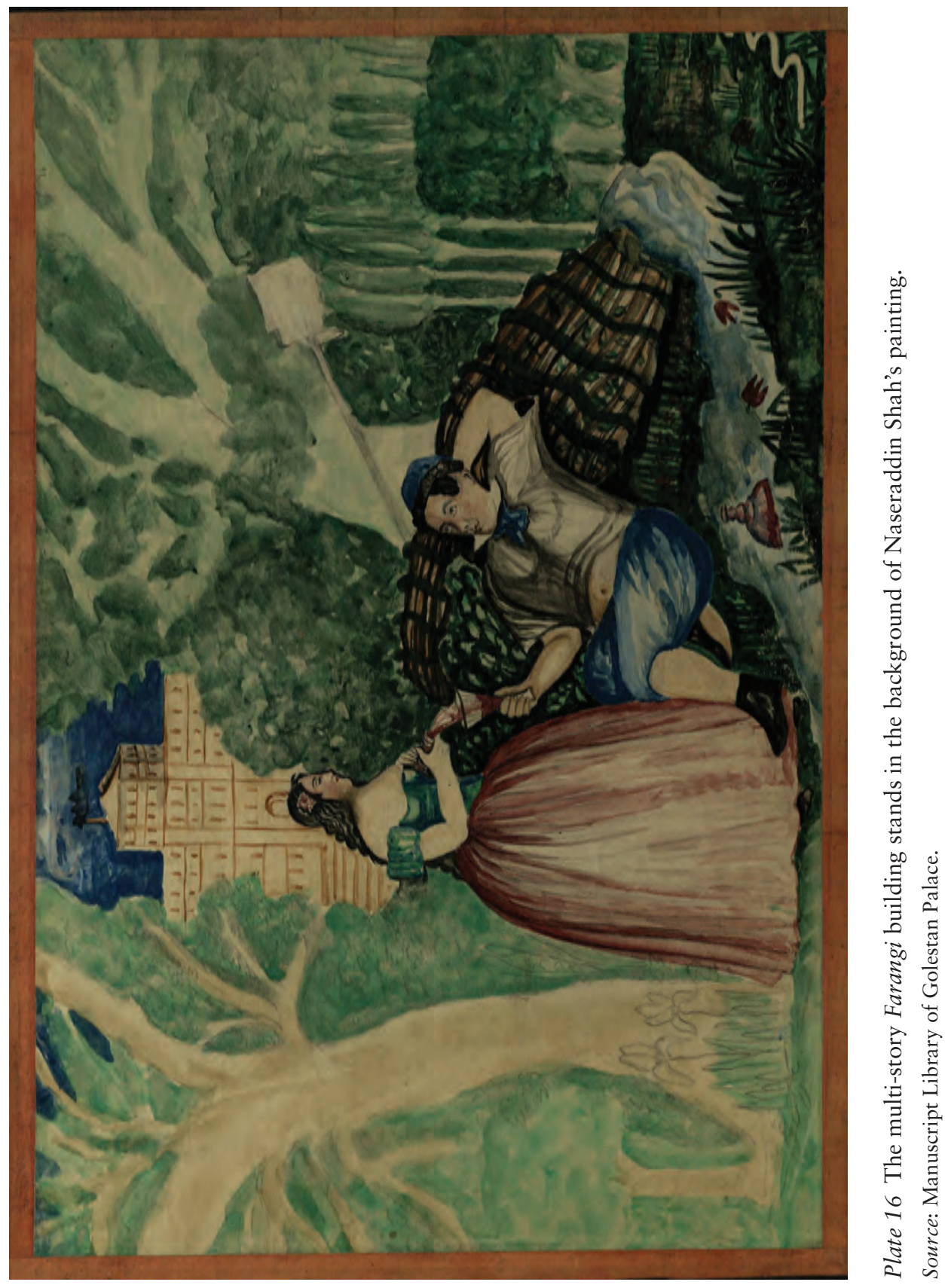


Aside from a few dubious reports, there is little historical evidence of other architectural projects that were directly initiated by the travelers studied here. ${ }^{51}$ Other members of their extended circle, however, were more involved in construction. Mirza Reza Mohandes, one of the students who traveled with Mirza Saleh, developed the plan of Darolfonun, Iran's first modern institution of higher education. ${ }^{52}$ Ajudanbashi contributed to numerous urban and architectural projects while serving as governor in Yazd and Fars; these efforts included forts, road construction projects, and water distribution systems. ${ }^{53}$ The detailed examination of these edifices and others that may have been influenced by the Farangi ideal is beyond the scope of this current book, though it is a study that I hope to pursue in the future.

The broadest influence of the travel journals, however, was not in their authors' direct activities but rather in the way their concepts were received and further developed by the rapidly expanding circle of Iranian visionaries who had access to these writings. The influence of the safarnameh genre in later years can be seen in the veneration with which reformers held the memoirs and the progressive narratives that they contained. Naseraddin Shah, who succeeded Mohammad Shah in 1848 and was responsible for initiating Farrokh-Khan's journey, was a strong fan of the literary journal and ordered many of his ambassadors to report their observations in a safarnameh format. Apparently, although these ideas helped the Shah envision a utopian future for Iran, they were unable to totally satisfy his curiosity about Farangestan. The Shah felt the urge to personally take part in what his modernizer vizier calls "the grand path to Iran's progress." ${ }^{54}$ Naseraddin Shah eventually undertook three personal excursions to Europe, in 1873, 1879 , and 1889. During these travels, the ruler took nearly all of the influential members of his cabinet with him. "It is not only the Shah who is traveling to Farangestan," his vizier observed, "but the entire government is seeking salvation by studying global affairs." 55

Aside from recording his own observations in a safarnameh format, ${ }^{56}$ Naseraddin Shah - who was a talented artist - created several paintings of Farangi people, mostly women and soldiers (see Plate 8$).{ }^{57}$ One particular painting, wherein Naseraddin Shah depicts a Farangi woman serving wine to a young man, fully encapsulates the arguments of this book (see Plate 16). While the picture is supposedly capturing a scene in Farangestan, its theme is in fact a familiar one. The romanticism of the story, its exotic landscape, and even the positioning of the figures (the drunken man lying beneath a tree and a standing woman serving wine) are identically repeated in many Persian miniatures. ${ }^{58}$ As in the diaries, where architectural discussions are contextual to the central events, the building in the painting serves as a distant background. It is a large multistory structure, elevated from the ground, and firmly erected upon "thick" columns. The elevation is symmetrically organized and features a modular order of windows, looking outward to a vast garden. As in the diaries, the garden is emphasized over the building, while its combination of greenery and fountains resemble the 
imagery associated with the Islamic heavens. Farangestan, whether written in words or depicted with paint, maintains its imagined eroticism and antiurban utopianism.

The vision of utopian progress ensconced in the travelogues exerted a powerful draw, but it did not sit well with everyone. Critical positions toward tajaddod, although originated as reactions against the ideals of the Mashruteh constitutional movement, have developed since, extending to Iran's contemporary sociopolitical structure. These resistances are often characterized in opposition to Western hegemony. Understanding the nature of the Farangi vision, however, allows us to see that they were in fact counter-discourses reacting against certain aspirations, ideals, and social structures that were not totally foreign, but were rather an intrinsic part of Persian culture. ${ }^{59}$ Such counter-discourses have generated many sub-cultures within the architectural world as well, which could serve as an interesting research topic for architectural historians.

\section{Epilogue}

To conclude this study, I shall again refer to the work of the Iranian filmmaker Asghar Farhadi, this time from his 2009 production, About Elly. This film epitomizes the spatial settings of Farhadi's movies, which are inevitably sites of unrest, spaces endlessly undergoing reconstruction. ${ }^{60}$ The setting for About Elly is a vacant house near the shores of the Caspian Sea, which is being cleaned, repaired, and refurnished by a group of friends to make it inhabitable for their weekend. The occupants are comfortable middle-class Iranian couples, all friends from their college days. Sepideh, who has organized the trip, brings along her daughter's schoolteacher, Elly, hoping to link her with another member of the group who has recently gotten divorced. All signs in the plot point to a potential marriage. Sepideh believes that her other friends "will all fall in love with [Elly]," and indeed they soon find Elly a "nice," "kind," "warm," quiet," and "uncomplicated" person.

When Elly goes missing, however, a disastrous sequence unfurls and these optimistic evaluations soon begin to darken. Those who suspect that Elly has left without notice now see her as "immature" and "unreasonable." It turns out that nobody really knew Elly as much as they had supposed. The enigma and skepticism that surrounds her continues to grow throughout the film, especially after the group is shocked by the arrival of Elly's fiancé. Many in the party feel that they have been misled about her apparent availability:

"An engaged woman looking for a husband! This means, first, she fooled us all, and second, she fooled her fiancé." 
"Fooled?"

"Obviously! If you have a boyfriend and your boyfriend finds a girl better than you for the weekend, to play volleyball. . . ."

"Where's the harm?"

"You don't understand. From our point of view there is no harm. But put yourself in the position of the fiancé, and everything is evil."

The enigma of tajaddod is also a matter of viewpoint. Nevertheless, similar to Elly's story, the total truth, even if accessible, is secondary to the main problem and thus irrelevant to our contemporary lives. The first generation of travelers who visited modern Europe had a judgment about modernity - one that similar to the group's first impression about Elly was filled with charm and attraction. They may not have known the basic historical and technical details of what they saw, as the group did not even know Elly's full name, yet they had a gut feeling about it that they decided to trust.

Today, our understanding of tajaddod is most similar to the children's memory of Elly in the movie. As in A Separation, the children represent the future generation whose destiny relies on the decisions of their elders. In the tragic drowning of Elly, this younger generation is both closer to the actual events and more directly affected by the experience. ${ }^{61}$ Yet they are largely derided by their parents, as if this generation is held responsible for the loss of Elly. To the police officers, who discontentedly "rely on children" to obtain the very basic information about Elly (such as her last name), their account of the events bears no weight. Similar to the children in the movie, who are relentlessly questioned, the new generations of Iranian people are today often unable to comprehend the relevance of the never-ending hypothetical inquisitions about the missing tajaddod.

For us today, modernity has no original conception. It is as if it had drowned many years ago; all we have is a memory, which is itself shaped by overlapping narrations that cannot be totally verified. We are in the same position as Sepideh at the end of the film, who is left with a choice of whether she should try to "save the honor of Elly," or whether she should try to avoid the embarrassment of admitting that she herself was the one who persuaded Elly to meet a new person. She has to address the impossible task of determining what interpretation to give to events. As one of the characters of the movie says, "We must decide now." Iran's experience of modernity likewise gains its meaning not from historical facts but from how we decide to interpret it. The search for the drowned body of European modernity in the seas of Iran's intellectual history is less relevant than are our own complex goals and aspirations that have led us to this point. Tajaddod should be thus sought not in unchartered waters but in the eyes of the beholders. 


\section{Notes}

1 Alfred de Musset et al., The Complete Writings of Alfred De Musset, 68.

2 Sohrabi, Taken for Wonder, 30.

3 See Tavakoli-Targhi, Refashioning Iran, 42, 43.

4 Abolhasan's political mission in Russia was unsuccessful, but he brought back another memoir detailing the accounts of this journey (Abolhasan Ilchi, Safarnameh-Ye Mirza Abolhasan).

5 Mirza Saleh Shirazi, Majmueh Safarnameha, 115, 119.

6 Ibid., 43.

7 Khosrow Mirza's trip was also documented as travel memoir(see Mostafa Afshar, Safarnameh-Ye Khosrow Mirza).

8 Another notable figure among the group was Mirza Mohammad Khan Zanganeh.

9 See Afshin Molavi, The Soul of Iran.

10 See Kambiz Eslami, "Ajudanbashi," 95.

11 Ajudanbashi had formerly served under the supervision of Mohammad Khan Zanganeh.

12 Moshiri, Sharh-e Mamuriyat-e Ajudanbashi.

13 Eslami, "Ajudanbashi."

14 Hasan Morsalvand, "Introduction.”; Tavakoli-Targhi, Refashioning Iran, 32, 33.

15 George Curzon, Persia and the Persian Question, 1, 24.

16 James Justinian Morier, A Journey through Persia.

17 The Adventures of Hajii Baba.

18 Abbas Amanat, "Hajji Baba of Ispahan."

19 Shirazi, Majmueh Safarnameha, 155.

20 Peter Avery, "Ouseley, Gore."

21 Shirazi, Majmueh Safarnameha, 177, 353; William Price and Mirza Saleh Shirazi, A Grammar of the Three Principal Oriental Languages, vi.

22 Tavakoli-Targhi, Refashioning Iran, 32.

23 Rezaqoli Mirza, Safarnameh, 355, 476.

24 Moshiri, Sharh-e Mamuriyat-e Ajudanbashi.

25 Fraser, Narrative of a Journey into Khorasan, 149-152.

26 Denis Wright, "Fraser James Baillie."

27 The Constitutional Revolution of Mashruteh took place between 1905 and 1907.

28 Farrokh Taheri, "Doktor Jamshid Behnam"; see also Nassereddin Parvin, "Tajaddod."

29 Ali Jadid Bonab, "Jostari Dar Farhang."

30 Rezaqoli Mirza, Safarnameh, 704.

31 Mirza Agha Khan Kermani (1854-1896) and Mirza Fathali Akhundzadeh (1812-1878), for example, associated changement with tajaddod (Sirus Alinejad, "Modernite Bayad").

32 See ibid.

33 See Mohsen Habibi and Zahra Ahari, Sharh-e Jarianhai-e Fekri.

34 Fraser, Narrative of the Residence, 92.

35 Abolhasan Ilchi, A Persian at the Court, 270, 274.

36 Abolhasan's servants, for example, were displeased with the quality of the pistols they had received from Sir Gore Ouseley (Ilchi, Heyratnameh, 270, 331).

37 Morier for example was amazed by

the facility with which [a Persian] adopts foreign manners and customs. I remarked two instances during our stay at Constantinople: the first occurred one morning when I went to visit the mirza [Abolhasan], where one of his servants took off his cap and saluted me by a bow in our fashion: again, at a 
ball, several of his attendants took off their caps and sat bald-headed, from the supposition that it was disrespectful in European company to keep the head covered, whilst they saw every one uncovered. There were many other accommodations to our usages which would never have been yielded by a Turk; such as eating with knives and forks, sitting at table, drinking wine, \& c.

(Morier, A Journey through Persia, 354)

38 In at least one occasion, as Morier reports, Abolhasan's servants, seated themselves cross-legged in a public coach ("The Mirza Abul Hassan”).

39 Ilchi, A Persian at the Court, 208.

40 Heyratnameh, 240.

41 Morier, "The Mirza Abul Hassan," 2; Ilchi, Heyratnameh, 26, 87.

42 Two of Rezaqoli's servants, a cook and a tailor, had decided to stay in London. Fraser associated their desire to stay to the drinking and sex habits that were developing (Fraser, Narrative of the Residence, 310, 311). While one of Abolhasan's servants also frequented London's brothels, such arguments are not sufficient to explain the servants' desire to stay in Europe (Ilchi, A Persian at the Court, 317).

43 Fraser, Narrative of the Residence, 310, 311.

44 Colonel Johnson's account of his 1817 visit with Abolhasan in Tehran is cited in "Meerza Abul Hassan."

45 William Richard Holmes, Sketches on the Shores of the Caspian, 366.

46 Fraser, Narrative of a Journey into Khorasan, 152.

47 Edward Backhouse Eastwick, Journal of a Diplomate's Three Years' Residence in Persia, 260.

48 Me'mar Helli, a master builder and expert in Kashan's premodern practices of architecture, believes that no other bazaar in Iran has the height and width of Timcheh-ye Aminoddowleh.

49 Aminoddowleh, Makhzanol Vaqaye', 270.

50 Ibid., 196.

51 Abolhasan is said to have supervised the construction of a mosque in Tehran, though the details of this effort and its outcome are uncertain (Morsalvand, "Introduction," 37). Rezaqoli is reported by the editor of his diary to have funded the construction of the Baqer-Abad mosque in Shiraz; however, the building in question dates back to the eighteenth century and its plaque inscriptions name a different individual as its patron. Even if we suppose that Rezaqoli contributed funds to the mosque's development, his influence on its architecture would likely have been minimal, since the traveler took asylum in Iraq after leaving Europe and never returned to Shiraz (Rezaqoli Mirza, Safarnameh, 746). Some scholars have suggested that Farrokh-Khan was the founder of a mosque in the Chalehmeydan neighborhood of Tehran. However, details about this contribution are vague. It is quite possible that these scholars are confusing the traveler Aminoddowleh Abu-Taleb Farrokh Khan Ghaffari with another individual, Mirza Ali Khan, who shared the title of "Aminoddowleh" and who is indeed partially responsible for the construction of the Fakhroddowleh mosque on the Chalehmeydan Street (Hosein Sa'adatnuri, “Abutaleb Farrokh Khan-e Aminoddowleh Ghaffari,” 423; Aminoddowleh, Makbzanol Vaqaye”, 13).

52 Following the traditional layout of educational typologies in Iran, Darolfonun's classrooms were organized facing a central courtyard. The rooms had the same 4 by 4 square meter plan and the courtyard had a large reflecting pool in the middle. To accommodate the new spatial requirements for the increasing number of students, the building undertook a major development in 1890, in which most of the older sections were destroyed (John Gurney and Negin Nabavi, "Dār Al-Fonūn").

53 Moshiri, Sharh-e Mamuriyat-e Ajudanbashi, 13; Eslami, "Ajudanbashi."

54 Fereydoun Adamiyat, Andisheh-Ye Taraqqi. 
55 Ibid.

56 Naseraddin Shah, Ruznameh-Ye Khaterat, 1; Ruznameh-Ye Khaterat, 2; Ruznameh-Ye Khaterat. The subsequent Iranian ruler, Mozaffaraddin Shah, who was responsible for signing the progressive 1907 constitution, also kept a record of his multiple travels to Farangestan in 1900, 1903, and 1905 (Mozaffaraddin Shah, Dovvomin Safarnameh; Safarnameh-Ye Sevvom).

57 For Naseraddin Shah's published paintings and a discussion of his art, see Mohammad-Reza Behzadi and Nasrin Marjani, "Mashgh-e Shahaneh."

58 See, for example, a seventeenth-century mural on the walls of Chehel-Sotun Palace in Isfahan, Iran.

59 Articulating recent nationalistic and Islamist movements in the region as counterdiscourses aimed not purely at the West but rather at local modernities can provide a greater nuance in our understanding and approach to regional conflicts.

60 This constant spatial unrest is a typical feature in Farhadi's movies. In his A Separation, the apartment where the drama takes place is full of boxes of partially packed items, as Simin is in the midst of moving from the house and eventually from the country. In Fireworks Wednesday, the whole city is undergoing the craziness of Charshanbeh-Suri fireworks, right before the New Year, and in addition the householders have hired a professional cleaner to perform the annual (and ritualistic) cleaning of the house, known as khaneh-takani. Apart from the removed curtains and carpets, and the slipcovered furniture, the house has a broken window, which at some point in the film is measured for replacement by a glazier. In Le Passé, one of the rooms of the house is being cleared of furnishings and decorations, and is in the process of being painted.

61 The trauma causes an instance of bedwetting, which is particularly meaningful when compared to the similar incident in A Separation - one representing a trauma that will haunt the future and the other representing a crumbling image of the past.

\section{References}

Adamiyat, Fereydoun. Andisheh-Ye Taraqqi Va Hokumat-e Qanun, Asr-e Sepahsalar [the Idea of Progress and the Rule of Law in Sepahsalar's Era]. 1st ed. Tehran: Entesharat-e Kharazmi, 1972.

Afshar, Mostafa. Safarnameh-Ye Khosrow Mirza Beh Sanpeterzburg [Khosrow Mirza's Travel to Saint Petersburg]. Tehran: Ketabkhaneh-ye Mostowfi, 1970.

Alinejad, Sirus. "Modernite Bayad Az Darun-e Jame'eh Zohur Konad [Modernity Should Be Indigenous to the Society]." http://www.bbc.co.uk/persian/arts/ story/2005/04/050420_pm-cy-behnam.shtml.

Amanat, Abbas. "Hajji Baba of Ispahan." In Iranica, edited by Ehsan Yarshater, 561-568. New York: Columbia University, 2003.

Aminoddowleh, Farrokh-Khan. Makhzanol Vaqaye': Safarnameh-Ye Farrokh Khan$e$ Aminoddowleh [Aminoddowleh's Travelogue]. Majmu'eh Safarnameha-Ye Irani. 2nd ed. Tehran: Asatir, 1994.

Avery, Peter. "Ouseley, Gore." In Iranica, edited by Ehsan Yarshater. iranicaonline. org, 2004.

Curzon, George. Persia and the Persian Question. Second impression ed. Vol. 1, London: Longmans, Green, and Co., 1892. Texte imprimé.

Eastwick, Edward Backhouse. Journal of a Diplomate's Three Years' Residence in Persia. 2 vols. London: Smith, Elder and co., 1864.

Eslami, Kambiz. "Ajudanbashi." In Encycopedia of Islam, edited by Gudrun Krämer, Denis Matringe, John Nawas and Everett Rowson. Brill Online, 2014. 
Fraser, James Baillie. Narrative of a Journey into Khorasan, in the Years 1821 and 1822 Including Some Account of the Countries to the North-East of Persia; with Remarks Upon the National Character, Government, and Resources of That Kingdom. London: Longman Hurst Rees Orme Brown and Green, 1825.

- Narrative of the Residence of the Persian Princes in London, in 1835 and 1836. The Middle East Collection. New York: Arno Press, 1973.

Gurney, John and Negin Nabavi. “Dār Al-Fonūn.” Encyclopcedia Iranica, edited by Ehsan Yarshater. Vol. VI. New York: Bibliotheca Persica Press, 662-668, 1993.

Habibi, Mohsen, and Zahra Ahari. Sharh-e Jarianhai-e Fekri-e Memari Va Shabrsazie Dar Iran-e Moaser Ba Takid Bar Dorei-e Zamani-e 1357 Ta 1383 [Theoretical Movements in Contemporary Architecture and Urban Planning in Iran from 1972 to 2004]. Daftar-e Pajhoheshhai-e Farhangi (Cultural Research Bureau), 2007.

Holmes, William Richard. Sketches on the Shores of the Caspian: Descriptive and Pictorial. London: R. Bentley, 1845.

Ilchi, Abolhasan. Heyratnameh: Safarnameh-Ye Mirza Aolhasan Khan-e Ilchi Beh Landan [Wonderlogue: The Accounts of Ambassador Abolhasan Khan's Travel to London]. 1st ed. Tehran: Moasseseh-ye Khadamat-e Farhangi-ye Rasa, 1986.

- A Persian at the Court of King George: The Journal of Mirza Abul Hassan Khan. Translated by Margaret Morris Cloake. London: Barrie \& Jenkins Ltd, 1988.

- Safarnameh-Ye Mirza Abolhasan Khan Shirazi Beh Rusiyeh: Dalil as-Sufara [Abolhasan Khan's Travel Memoir of Russia]. Tehran: Donya-ye Ketab, 1984.

Jadid Bonab, Ali. "Jostari Dar Farhang Va Tamaddon-e Eslami [an Introduction to Islamic Culture and Civilization]." Boshra no. 55 (2007): 38-43.

Marjani, Mohammad-Reza, and Behzadi Nasrin. "Mashgh-e Shahaneh: Moraghgha'at-e Naghghashi Naseraddin Shah-e Ghajar Dar Ketabkhaneh-Ye Saltanati-Ye Sabegh [Royal Sketches: Naseraddin Shah's Drawings]." Tarikh-e Mo'aser-e Iran no. 60 (2012): 269-332.

"Meerza Abul Hassan.-No. Ii." The Penny Magazine of the Society for the Diffusion of Useful Knowledge, October 25 1834, 2.

Molavi, Afshin. The Soul of Iran: A Nation's Journey to Freedom. New York: W. W. Norton, 2005.

Morier, James Justinian. The Adventures of Hajii Baba, of Ispahan. London: R. Bentley, etc., 1851.

- A Journey through Persia, Armenia, and Asia Minor, to Constantinople, in the Years 1808 and 1809: In Which Is Included, Some Account of the Proceedings of His Majesty's Mission, under Sir Harford Jones ... To the Court of the King of Persia. London: Printed for Longman, Hurst, Rees, Orme, and Brown . . . 1812.

- "The Mirza Abul Hassan." In The Adventurer of the 19th Century, Issues 1-37, 298-301. London: Knight and Lacey, 1823.

Morsalvand, Hasan. "Introduction." In Heyratnameh: Safarnameh-Ye Mirza Aolhasan Khan-e Ilchi Beh Landan [Wonderlogue: The Accounts of Ambassador Abolhasan Khan's Travel to London]. Edited by Hasan Morsalvand. Tehran: Moasseseh-ye Khadamat-e Farhangi-ye Rasa, 1986, 11-44.

Moshiri, Mohammad. Sharh-e Mamuriyat-e Ajudanbashi [Ajudanbashi's Mission]. Tehran: Ashrafi, 1968.

Mozaffaraddin Shah. Dovvomin Safarnameh-Ye Moz?Affaraddin Shah Be Farang [Mozaffaradding Shah's Second Trip to Farang] [in Persian.]. Manabe'-e TarikhiYe Moaser-e Iran. Edited by Fakhrol Molk. 1st ed. Tehran: Kavish, 1983. 
. Safarnameh-Ye Sevvom-e Mozaffaraddin Shan Be Farang [Mozaffaraddin Shab's Third Trip to Farang] [in Persian.]. Edited by Mohammad Naser Nasiri Moghaddam. Terhan: Markaz-e Asnad Majles, 2011.

Musset, Alfred de, Marie Agathe Clarke, Raoul Pellissier, Mary Helena Dey, and Kendall Warren. The Complete Writings of Alfred De Musset. 10 vols. New York: E.C. Hill Co., 1905.

Naseraddin-Shah. Ruznameh-Ye Khaterat-e Naseraddin Shah Dar Safar-e Avval-e Farangestan. Edited by Fatemeh Ghaziha. Tehran: Sazman-e Asnad-e Melli-ye Iran, 1998.

- Ruznameh-Ye Khaterat-e Naseraddin Shah Dar Safar-e Dovvom-e Farangestan. Edited by Fatemeh Ghaziha. Tehran: Sazman-e Asnad-e Melli-ye Iran, 2000.

- Ruznameh-Ye Khaterat-e Naseraddin Shan Dar Safar-e Sevvom-e Farangestan. Edited by Mohammad Esma'il Rezvani Tehran: Sazman-e Asnad-e Melli-ye Iran, 1990.

Parvin, Nassereddin. “Tajaddod.” In Encyclopaedia Iranica, edited by Ehsan Yarshater. New York: Bibliotheca Persica Press, 2004, 119-120.

Price, William, and Mirza Saleh Shirazi. A Grammar of the Three Principal Oriental Languages, Hindoostanee, Persian, and Arabic, on a Plan Entirely New, to Which Is Added, a Set of Persian Dialogues. London: Kingsbury, Parbury, and Allen, 1823.

Rezaqoli Mirza. Safarnameh-Ye Rezaqoli Mirza Navey-Ye Fath Ali Shah [the Travel Account of Rezaqoli Mirza, Fath Ali Shah's Grandson]. Majmueh SafarnamehaYe Irani. Edited by Asghar Farmanfarmai Qajar. 3rd ed. Tehran: Asatir, 1994.

Sa'adatnuri, Hosein. "Abutaleb Farrokh Khan-e Aminoddowleh Ghaffari." Vahid Monthly 3, no. 5 (1966): 411-423.

Shirazi, Mirza Saleh. Majmueh Safarnameha-Ye Mirza Saleh Shirazi [Series of Travelogues by Mirza Saleh Shirazi]. Nashr-e Tarikh-e Iran. 1st ed. Tehran: Nashr-e Tarikh-e Iran, 1985.

Sohrabi, Naghmeh. Taken for Wonder: Nineteenth-Century Travel Accounts from Iran to Europe. New York: Oxford University Press, 2012.

Taheri, Farrokh. "Doktor Jamshid Behnam Az Iranian Va Andiesheh-Ye Tajaddod Miguyad [Jamshid Behnam Discusses the Idea of Tajaddod in Iran].” http://www. shahrvand.com/archives/28924.

Tavakoli-Targhi, Mohamad. Refashioning Iran: Orientalism, Occidentalism, and Historiography. St. Antony's Series. Houndmills, Basingstoke, Hampshire, New York: Palgrave, 2001.

Wright, Denis. "Fraser James Baillie.” In Iranica, edited by Ehsan Yarshater, 192195. New York: Columbia University, 2000. 


\section{Appendix A \\ Abolhasan's itinerary}

Note: My method in developing the itineraries in these appendices was to include as much information about the travelers' trips as possible. While I studied many sources (such as newspaper articles and the diaries of the travelers' companions) most of the information heavily depended on the travelers' diaries, which often did not apply a consistent style. For example, on some occasions the travelers mentioned the date that they arrived in a certain city, the dates for their daily activities, and the date when they left the city. On other occasions, they mention an event in a city without saying when they arrived, how long they stayed, or when they left the town. In many instances the dates, which are usually in an Islamic lunar calendar, did not match the day. In such cases, when I was unable to find the actual date through cross-references, I prioritized the day to adjust the date, as confusing weekdays was less likely, and also because lunar calendar inaccuracies are not uncommon. 


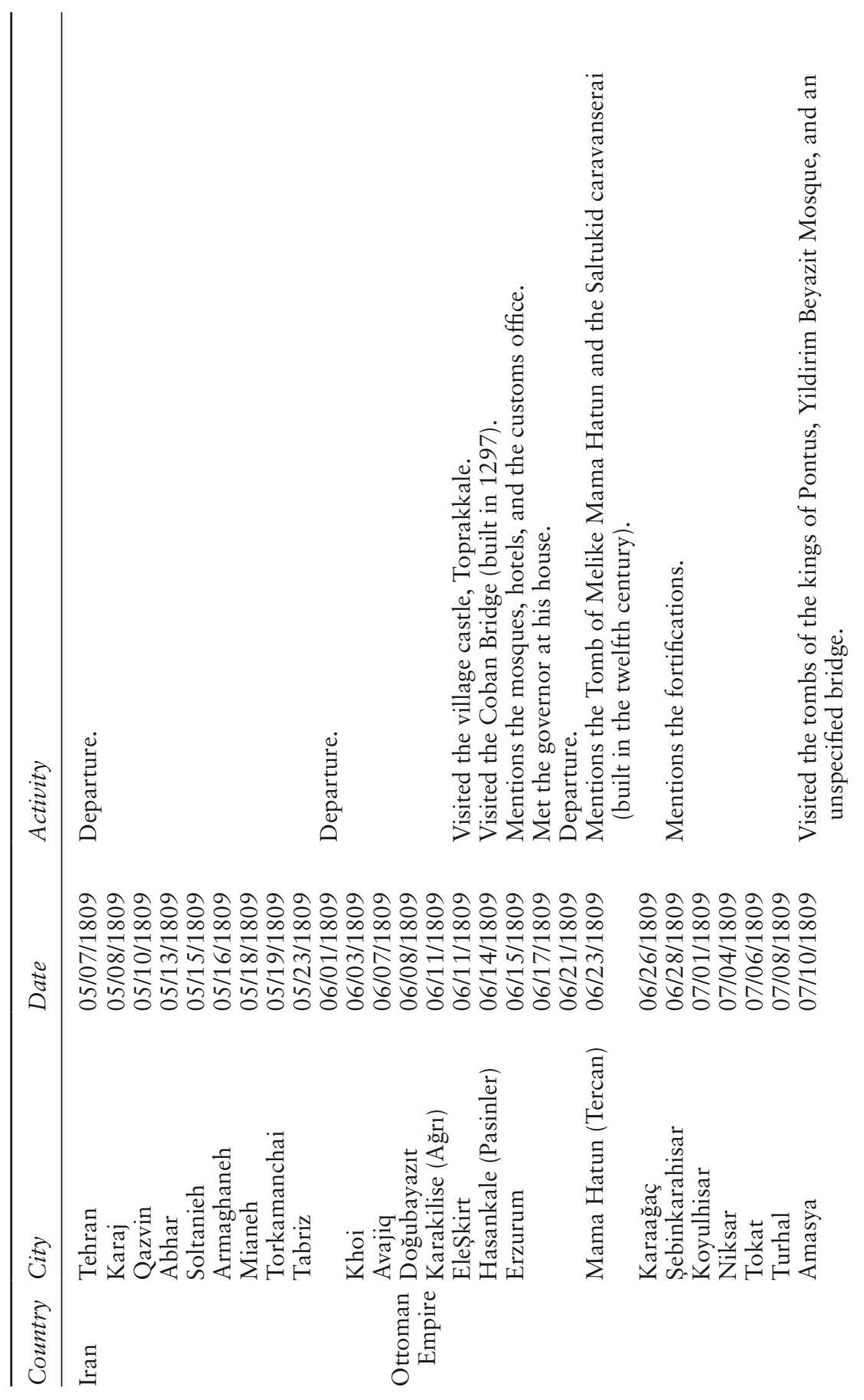



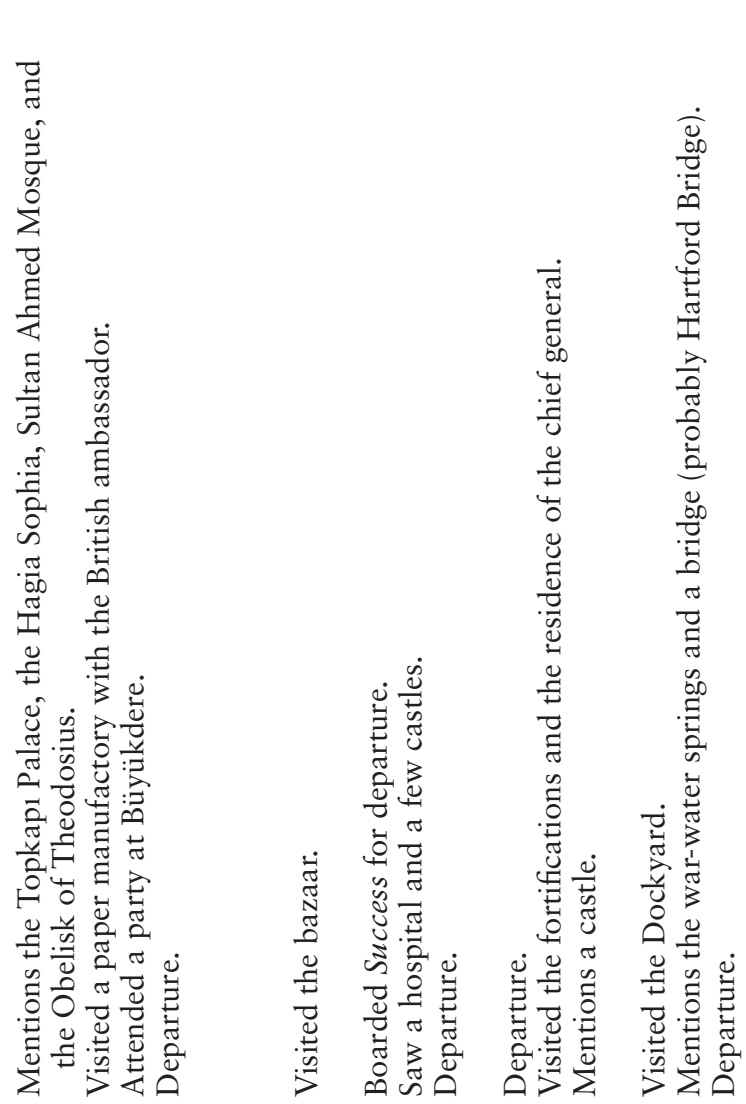

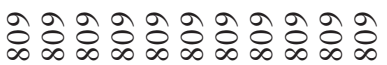

के

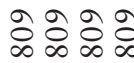

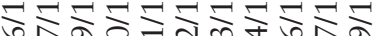

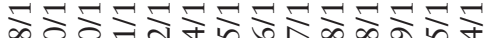

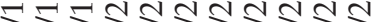
inmmososonosin

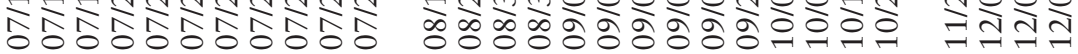

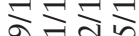

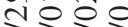

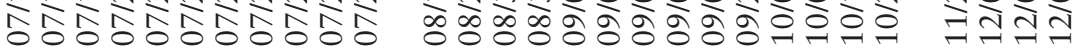
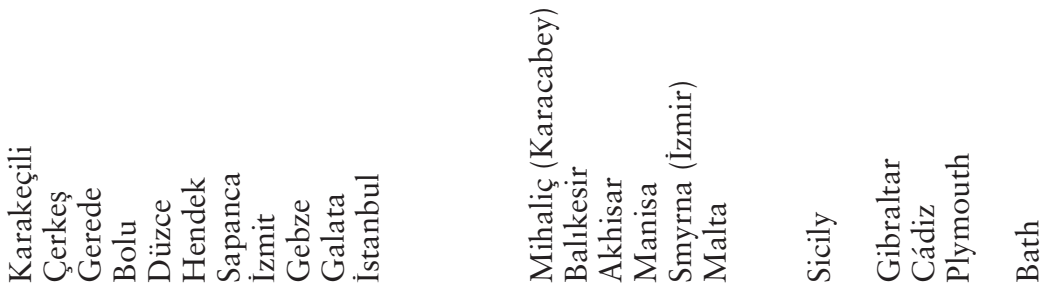

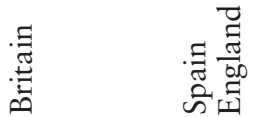




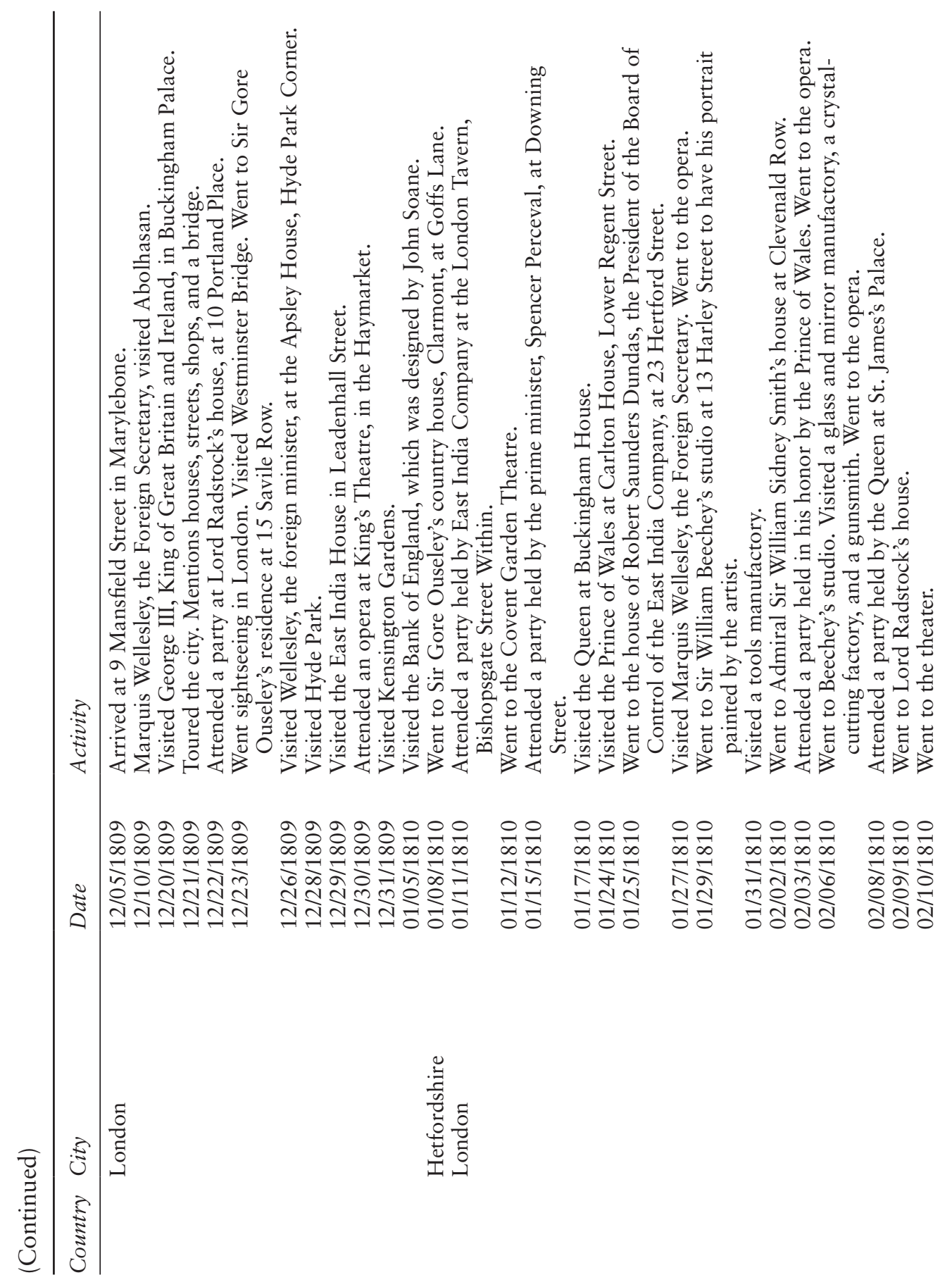




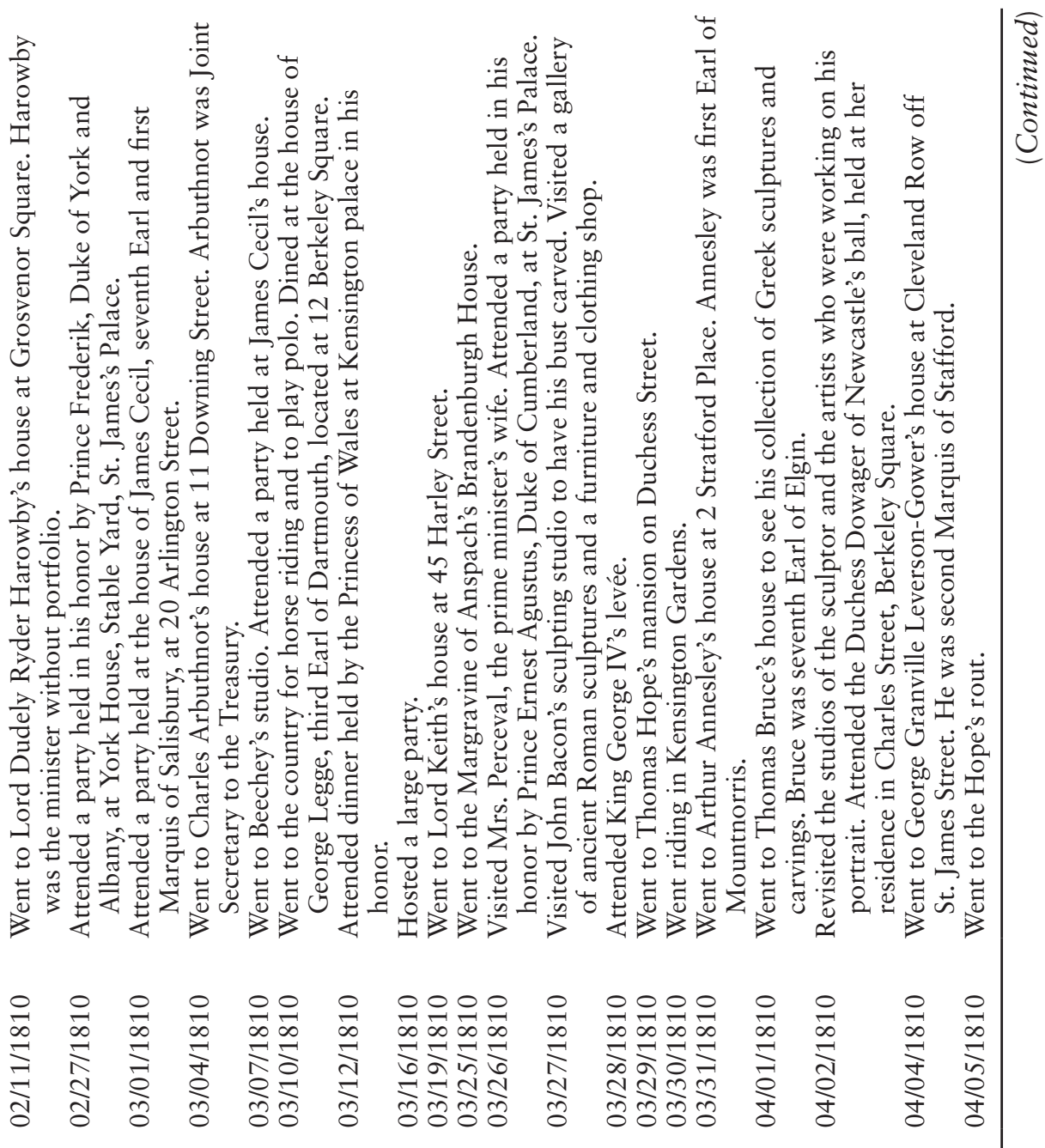




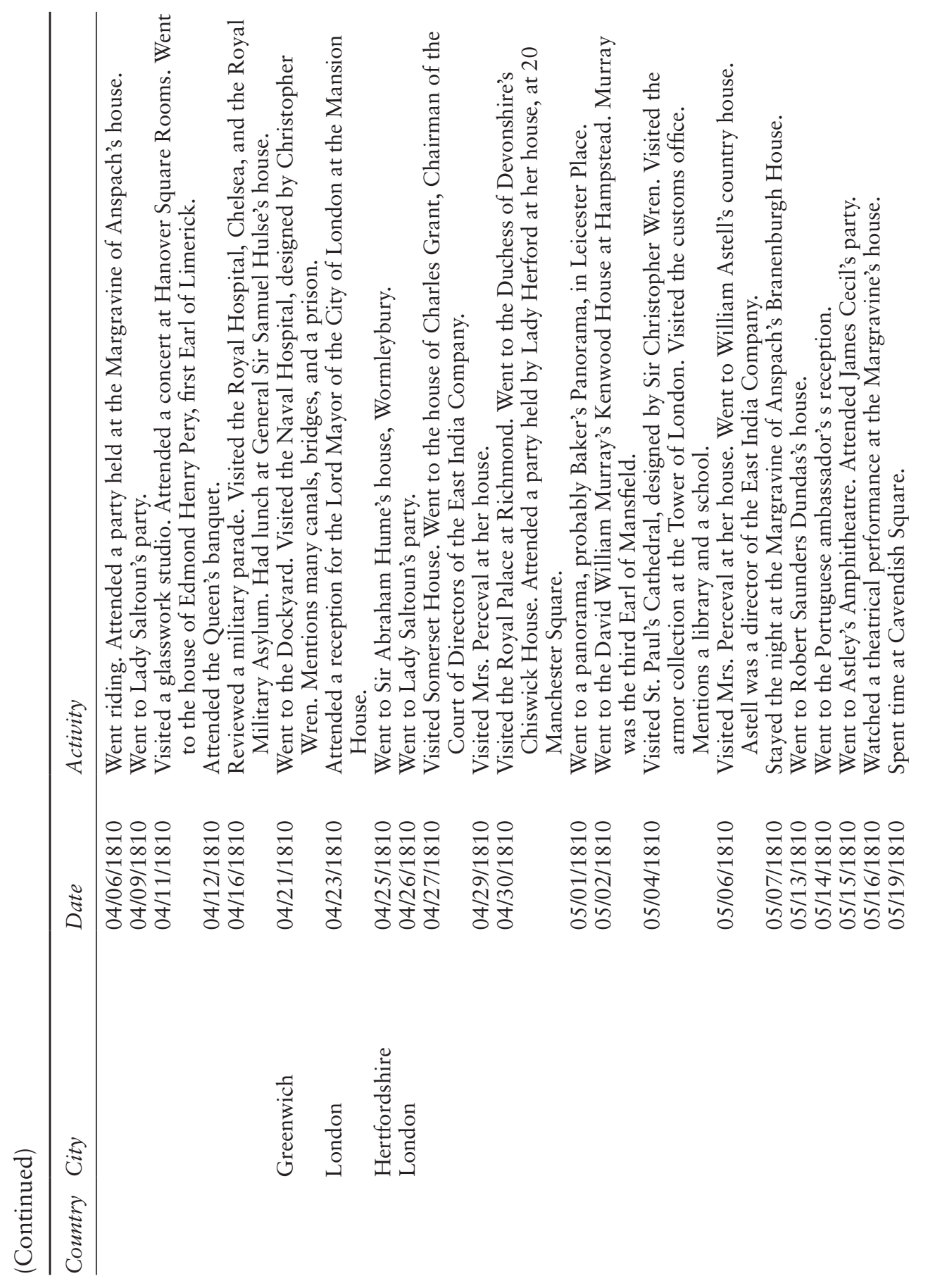




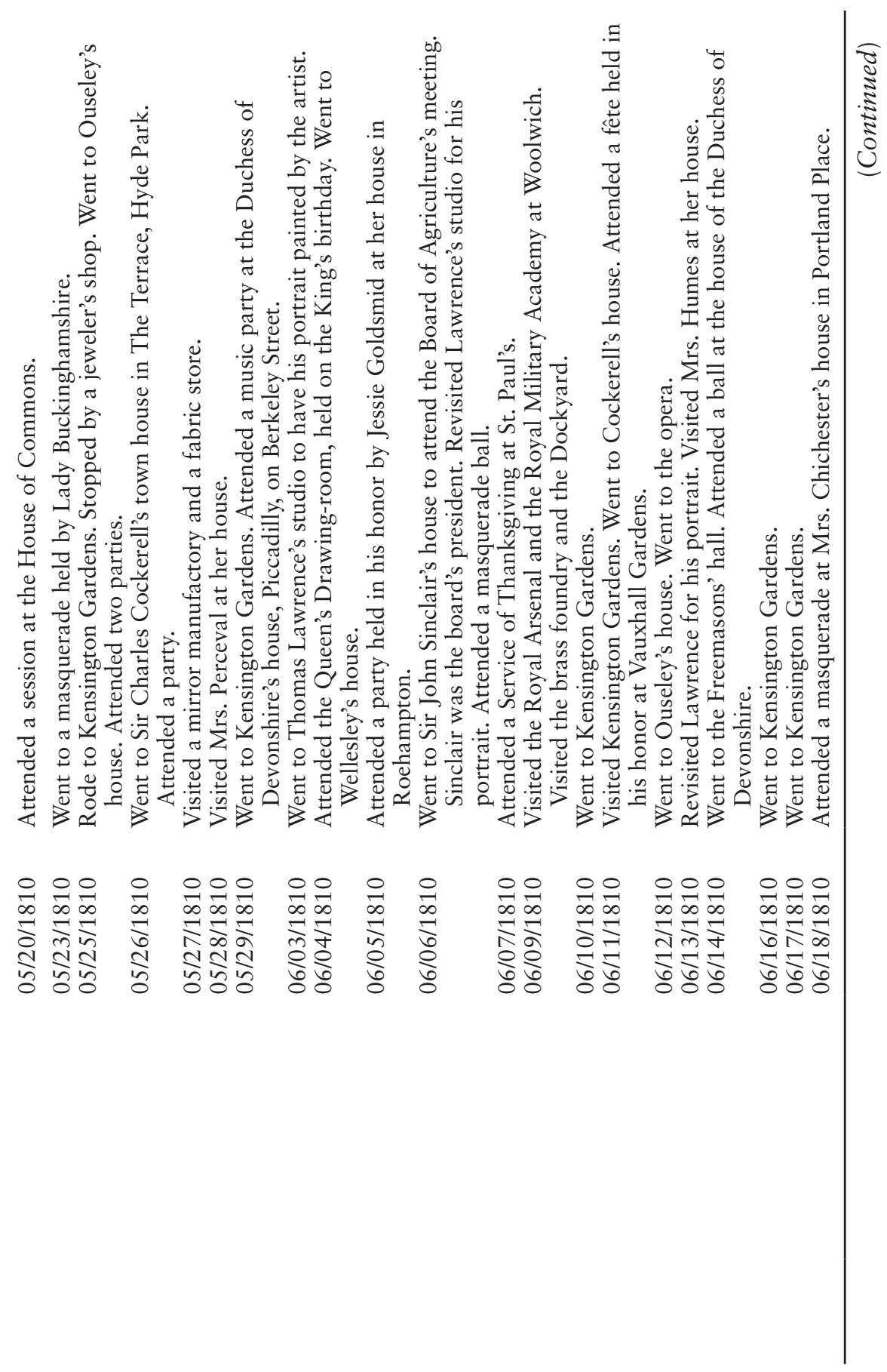




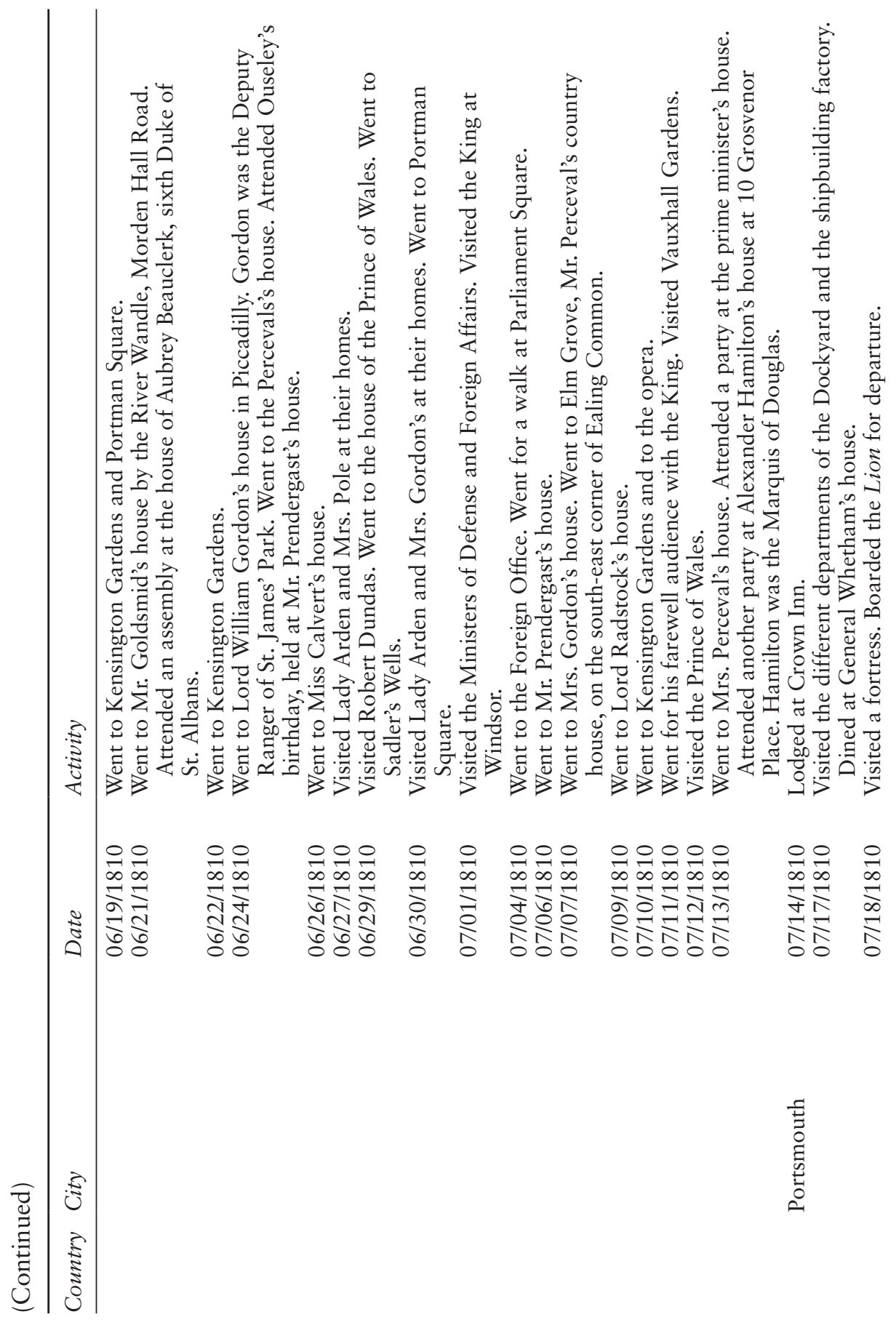




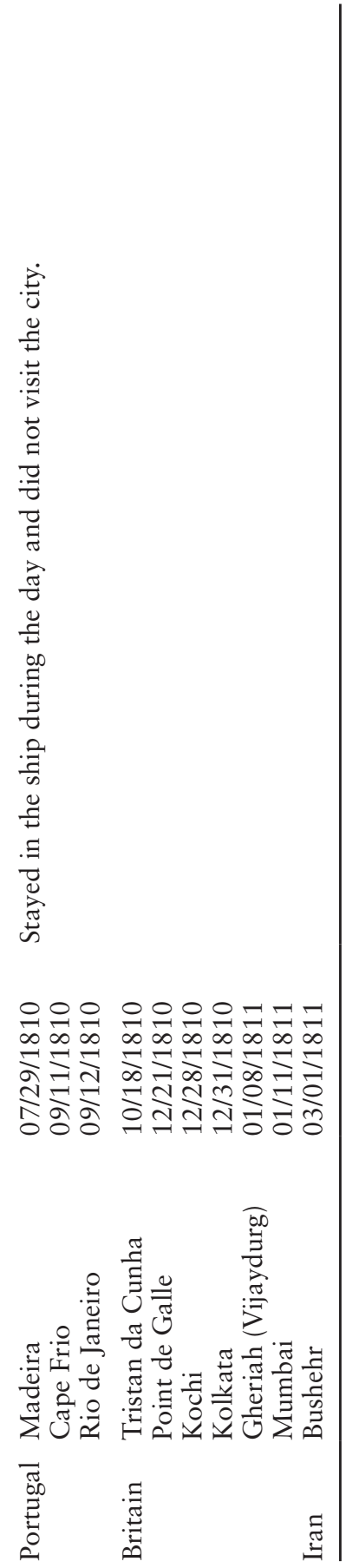




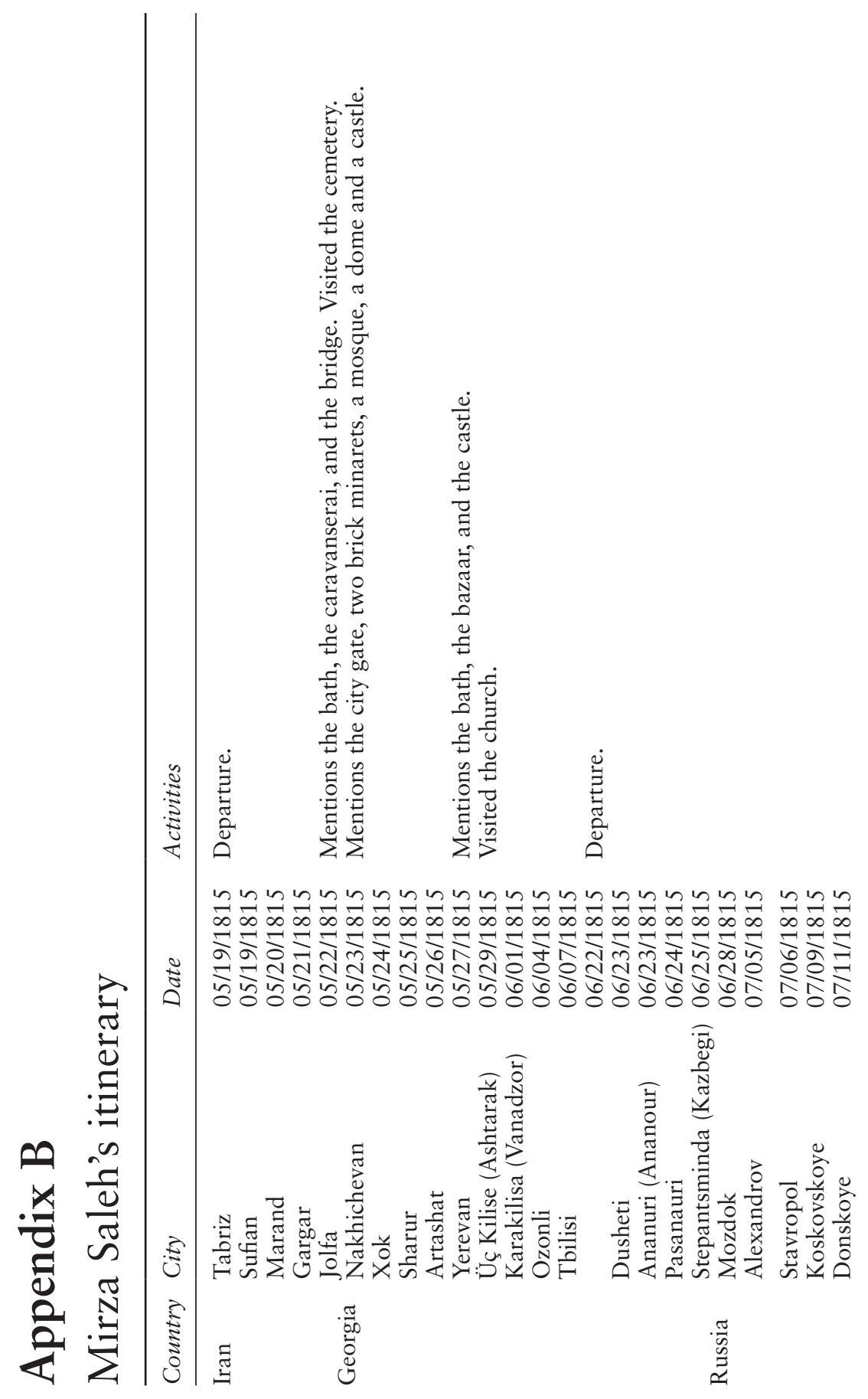



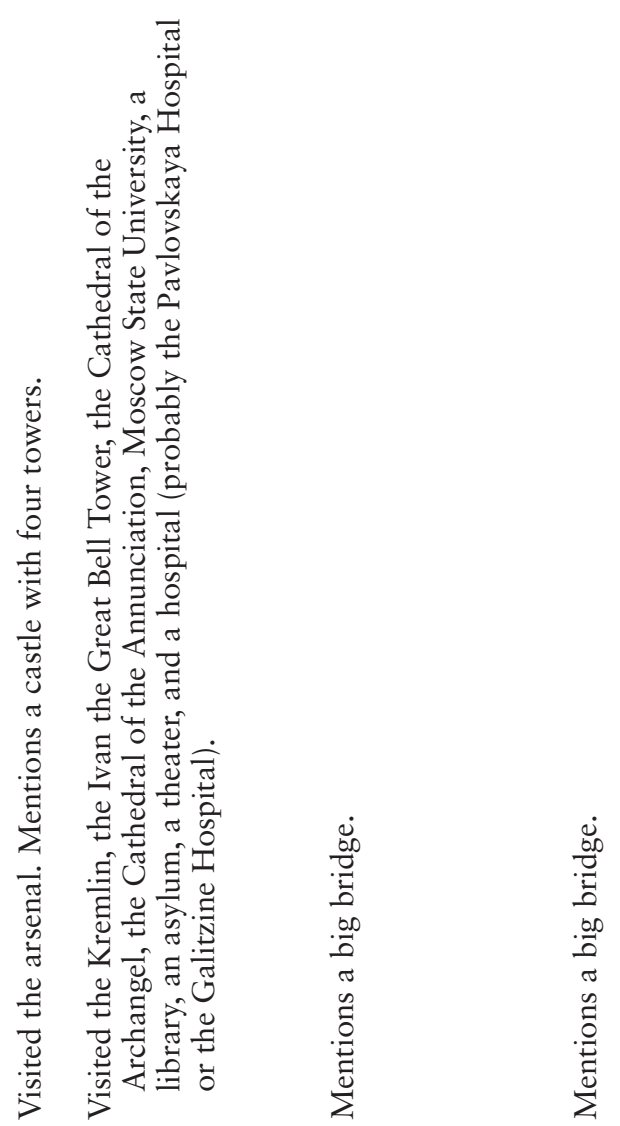

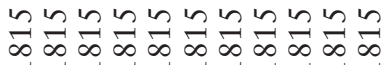

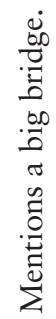

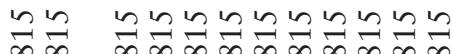
$\stackrel{\infty}{i} \quad \infty \quad \infty$

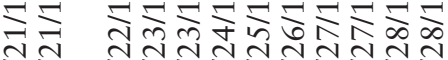
oo
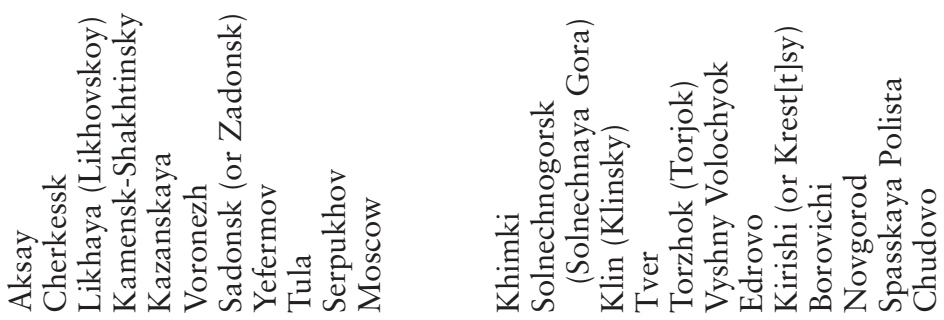


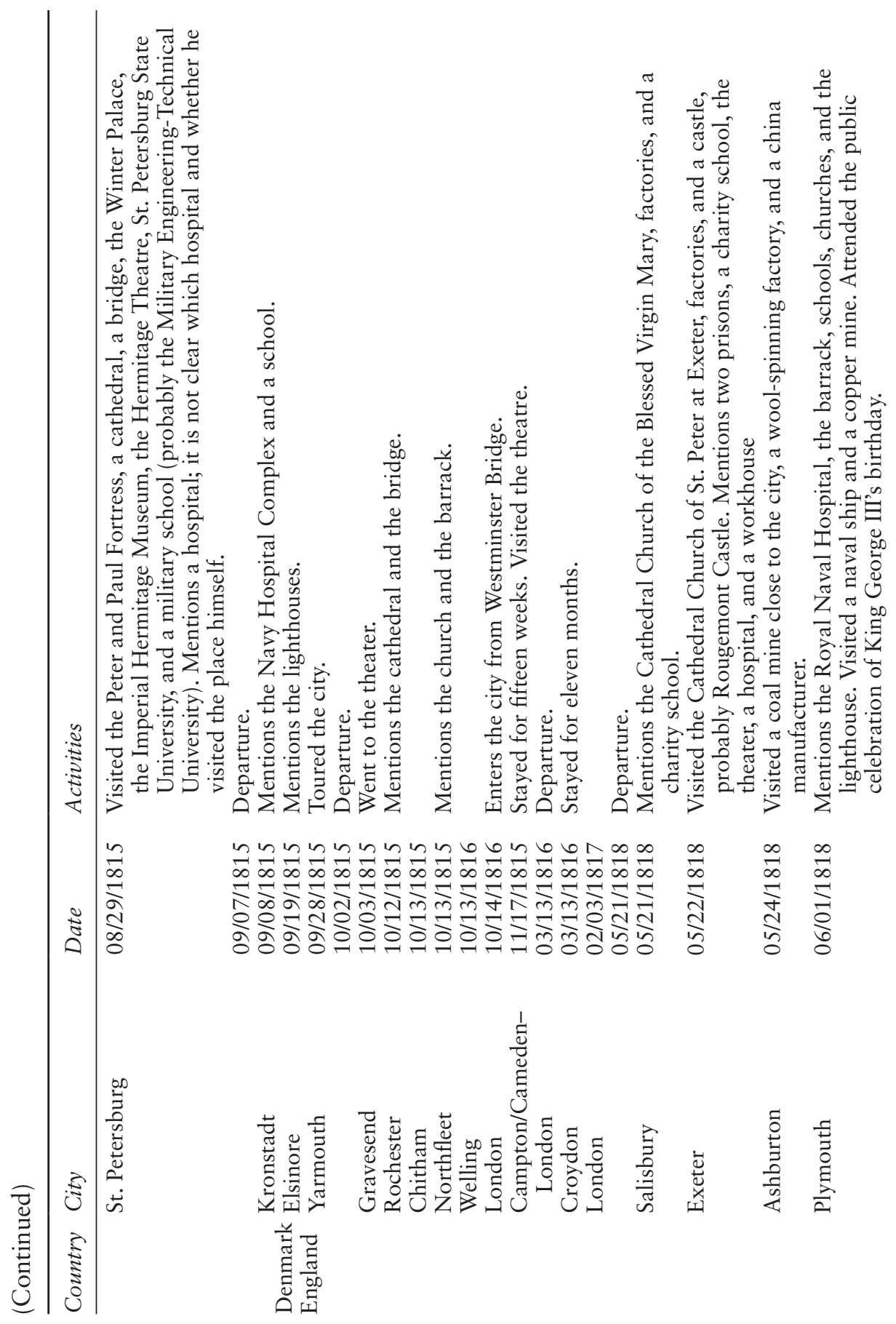




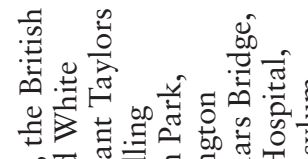

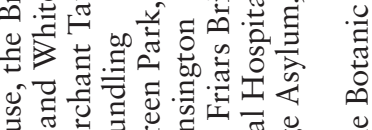

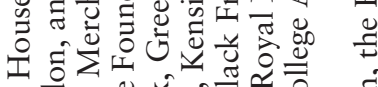

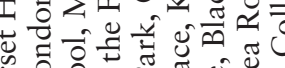

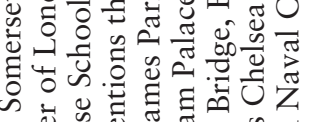

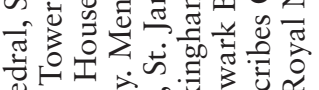

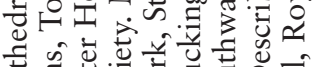

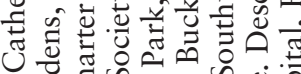

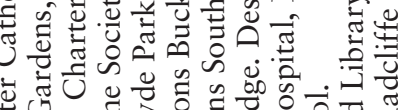

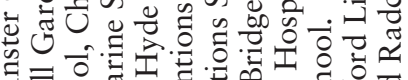

宗 要 \&

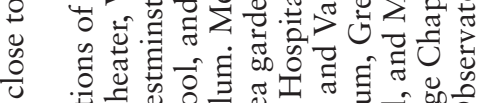

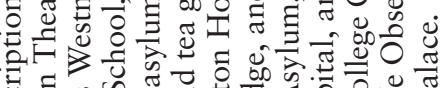

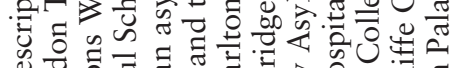
80

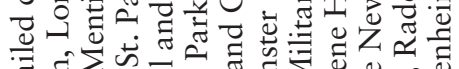

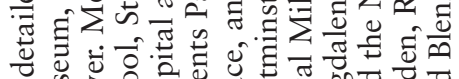

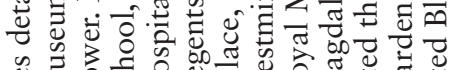

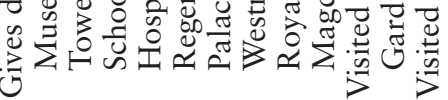
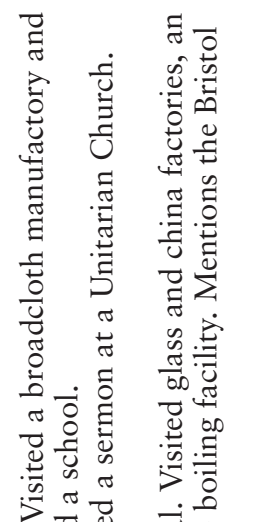

שֶ

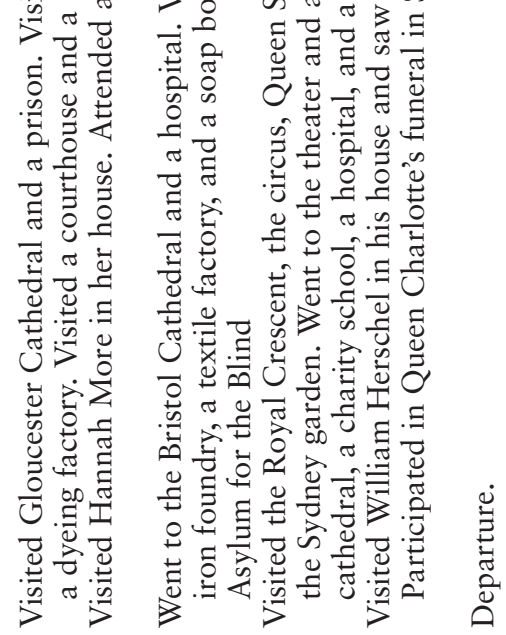

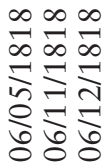

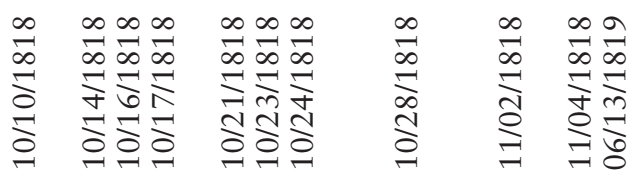

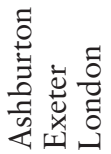

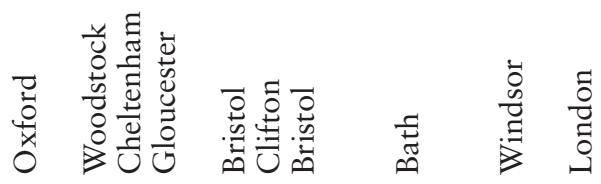




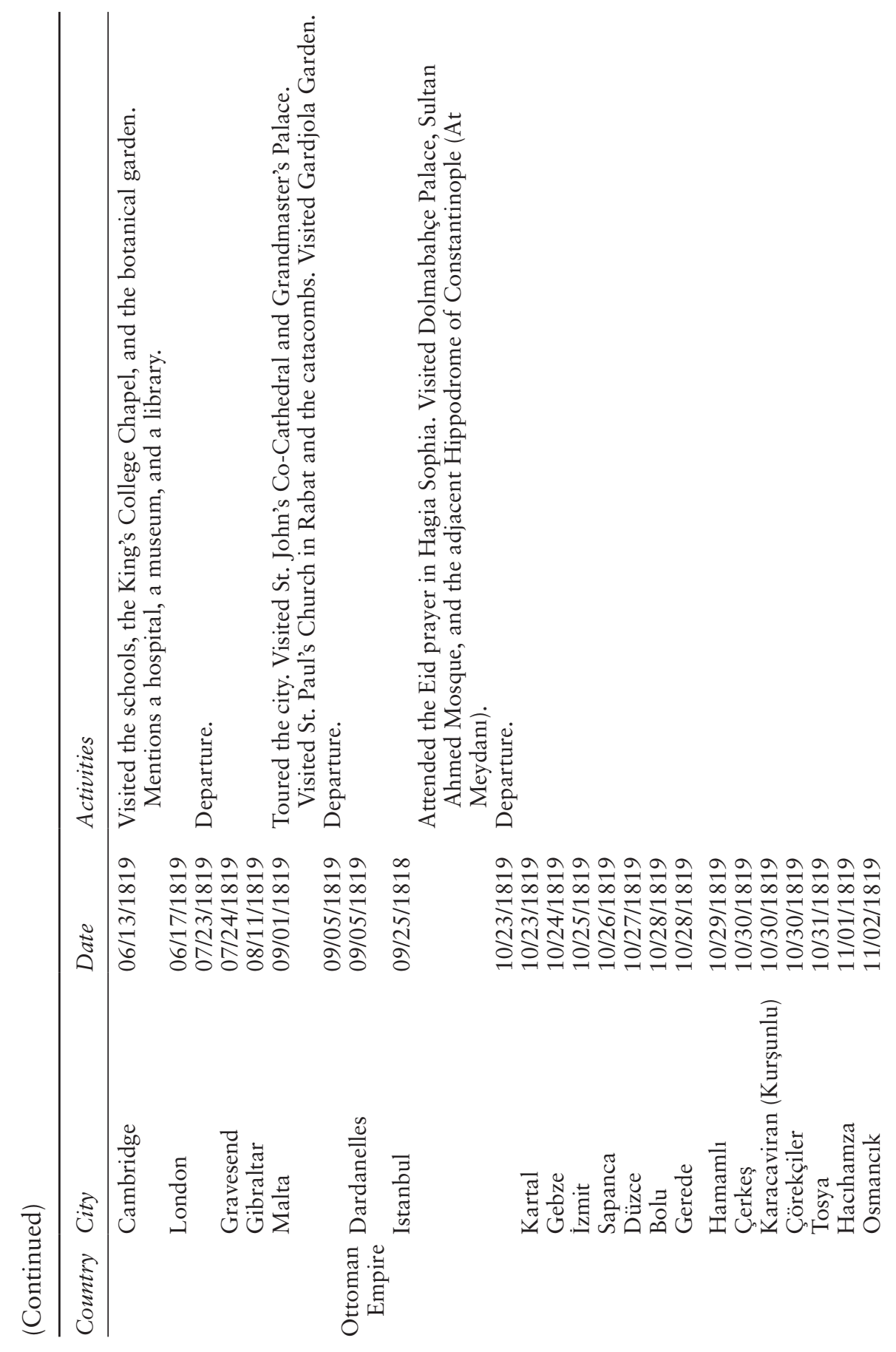




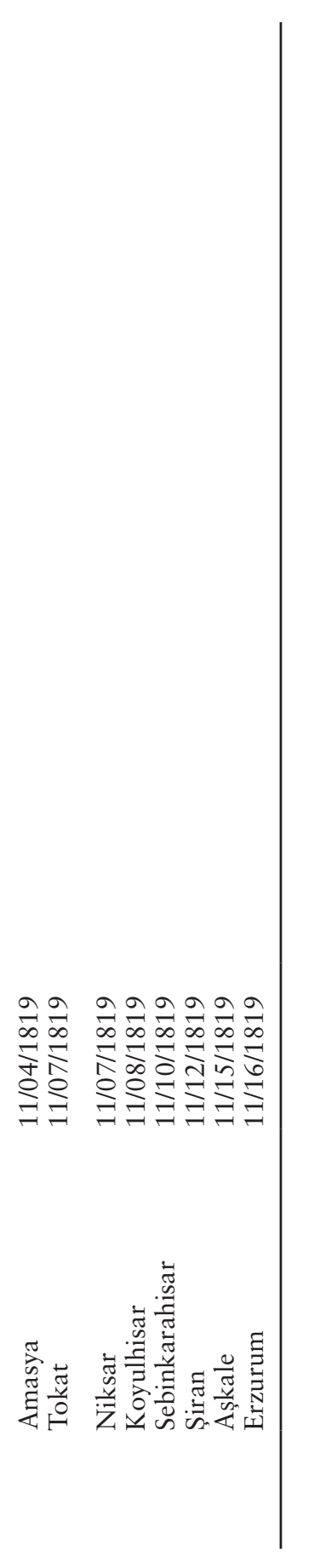




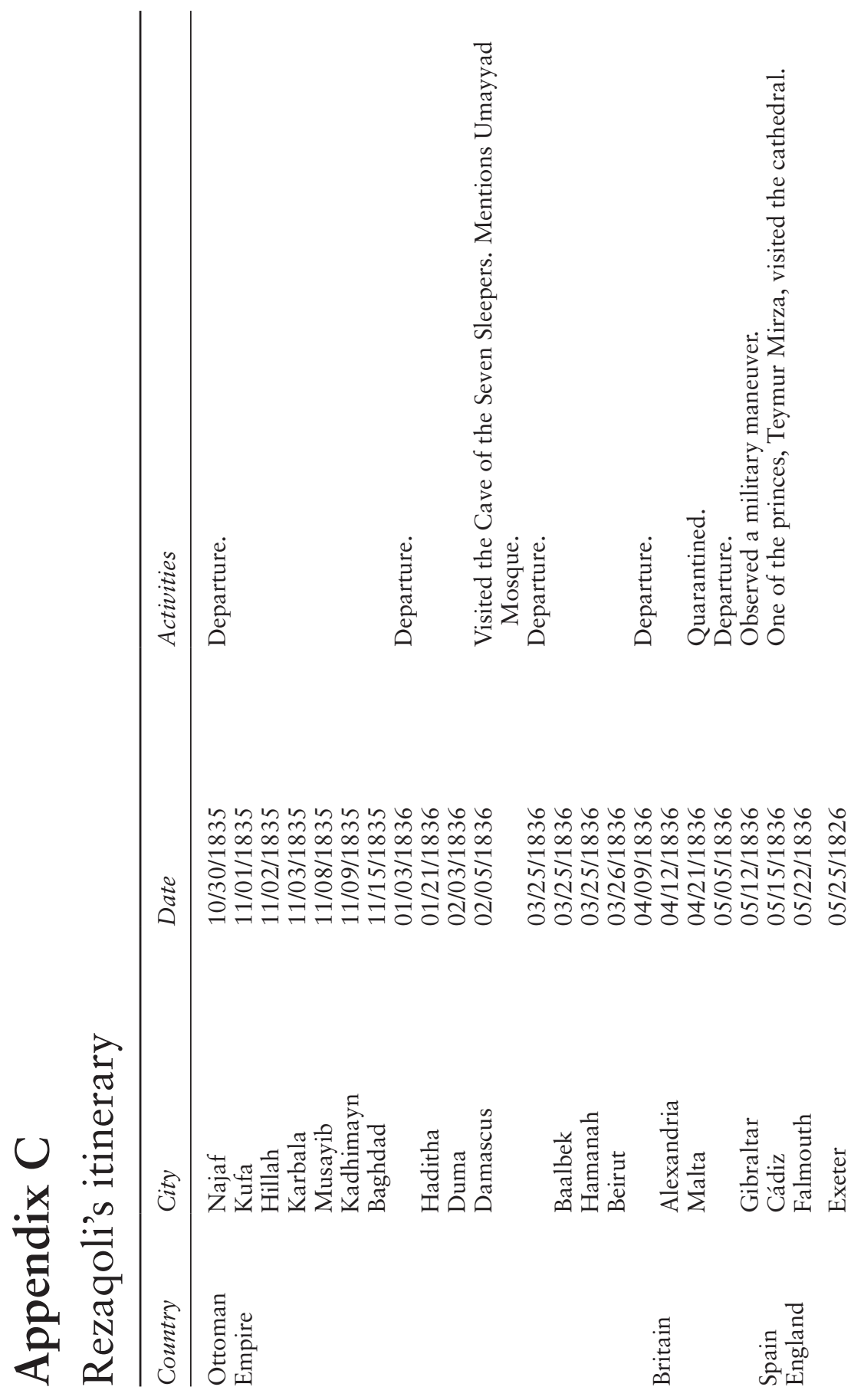




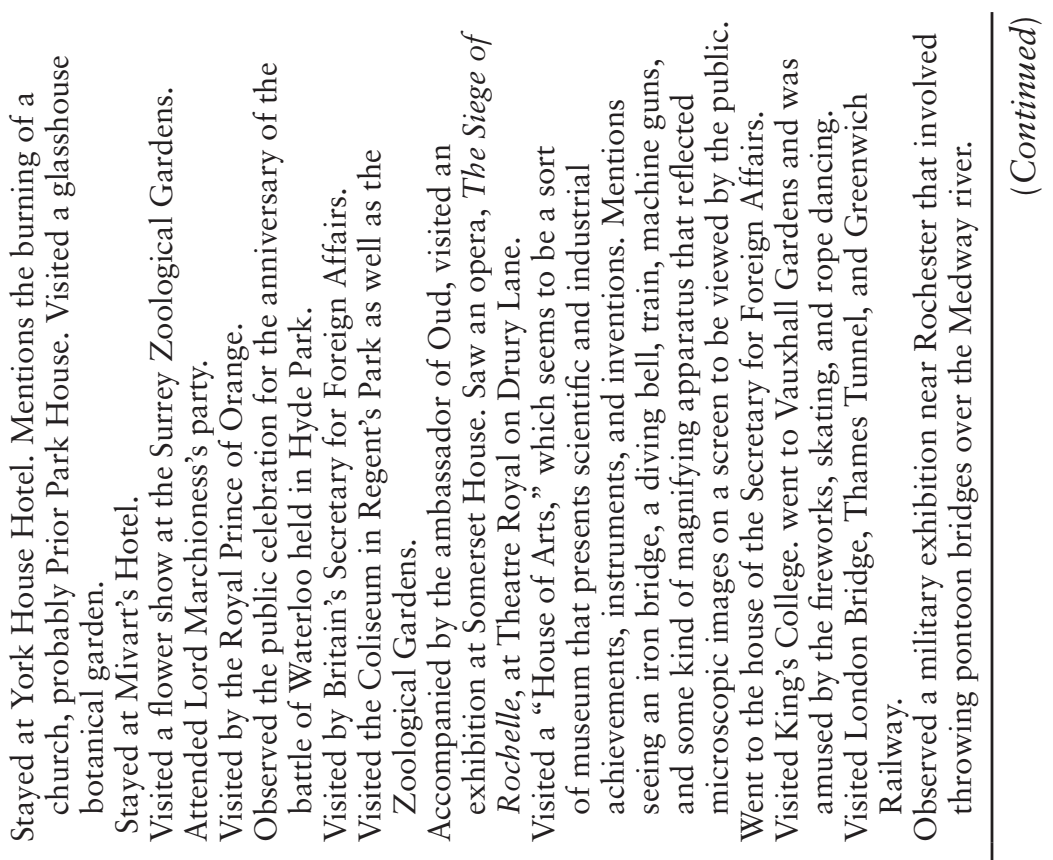

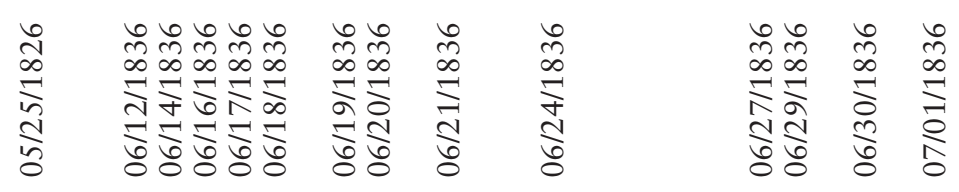

高 


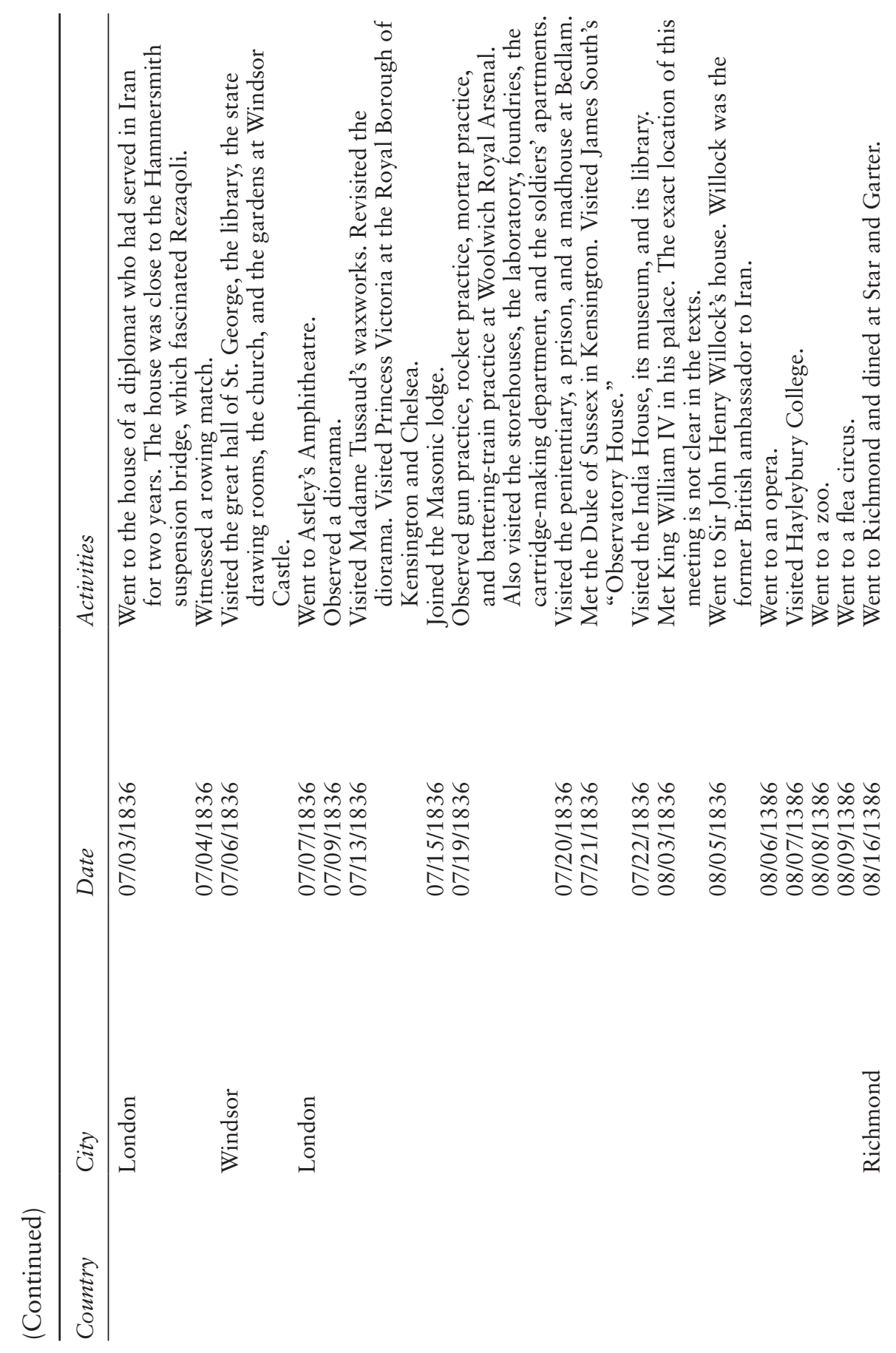



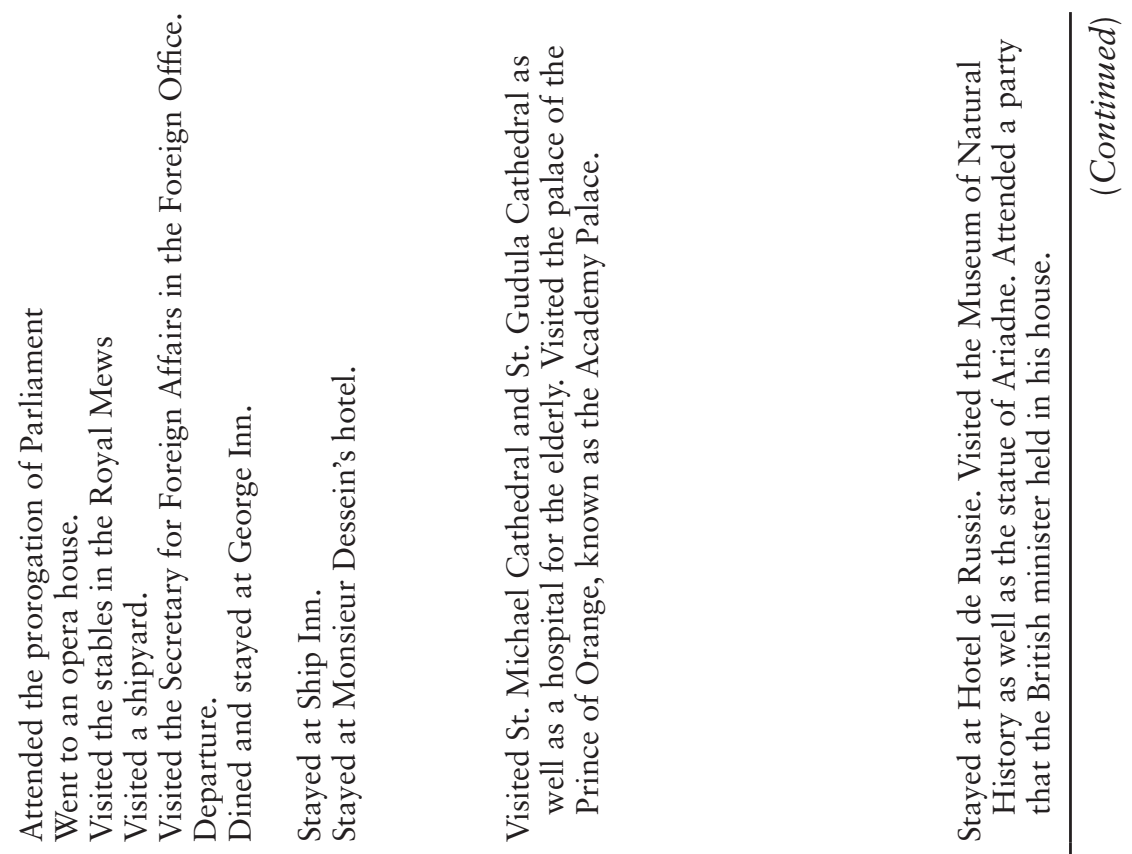

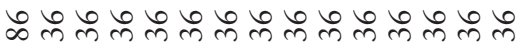
606666616660

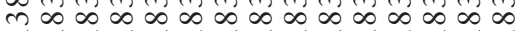
$\infty \infty \infty \infty \infty \infty \infty \infty \infty \infty \infty$ ๖

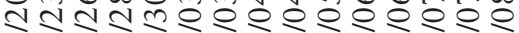

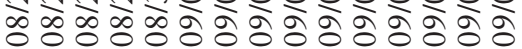

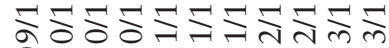
ํํำํํำำำำำำำำำำำ
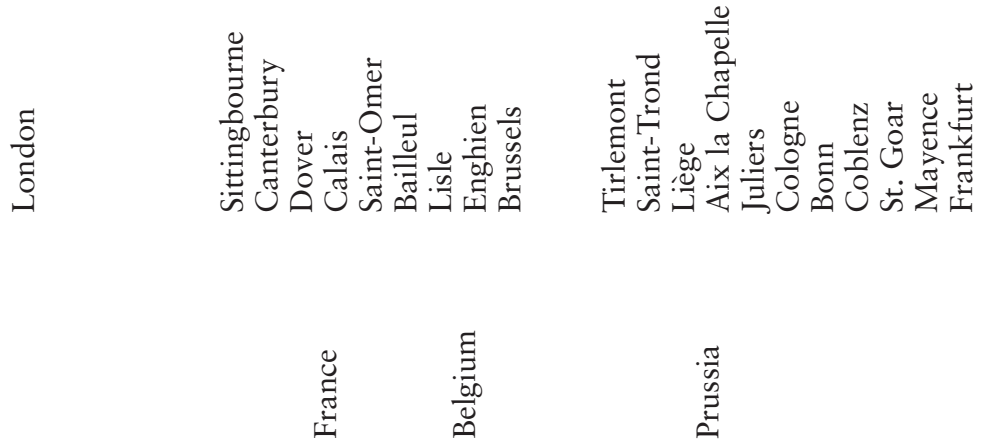


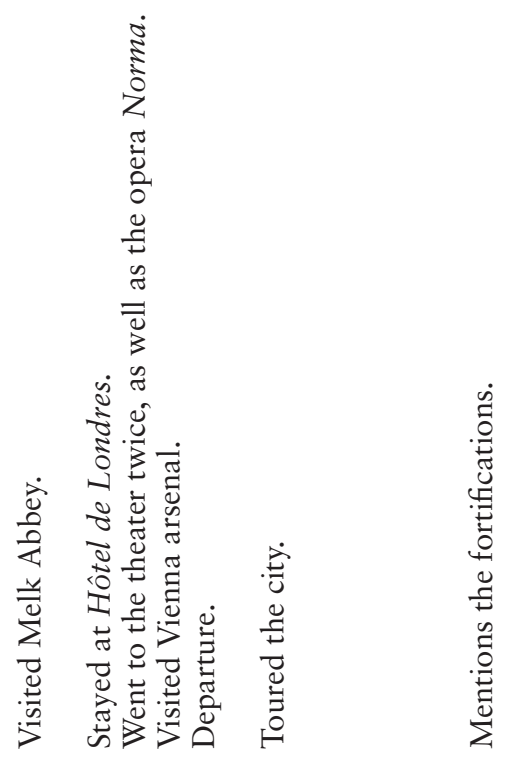

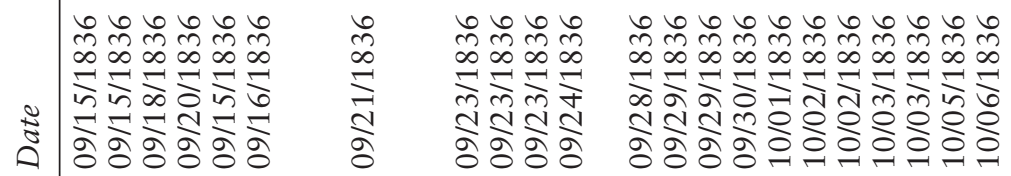

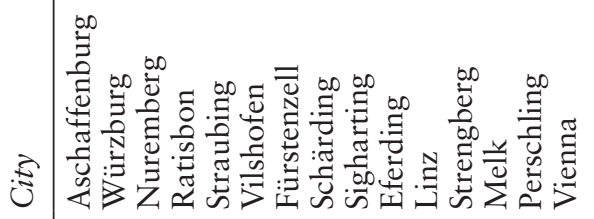

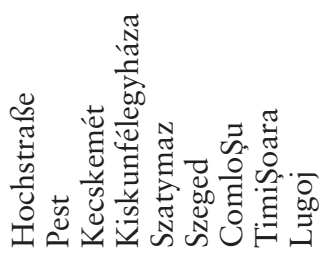

葛

营

莺 


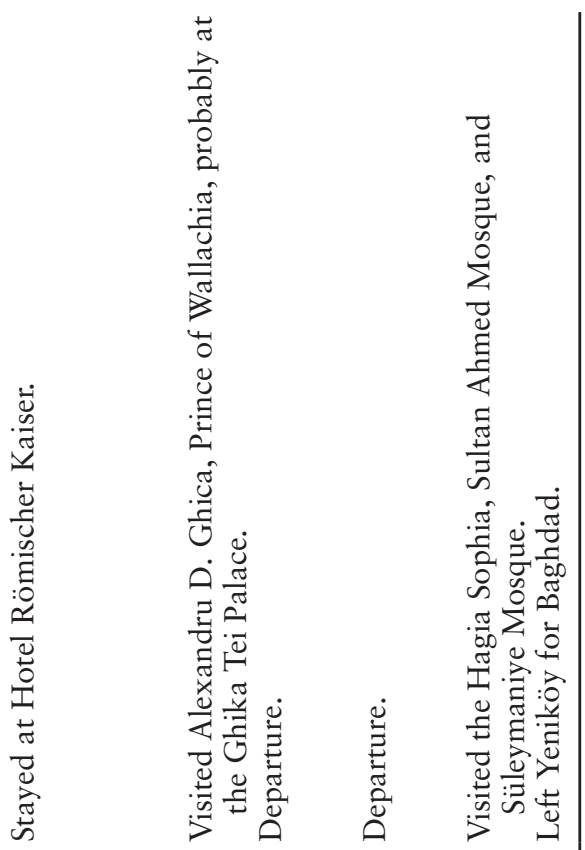

అங்

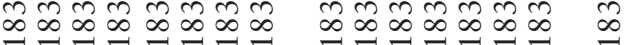

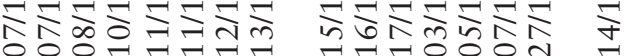

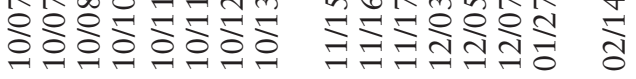

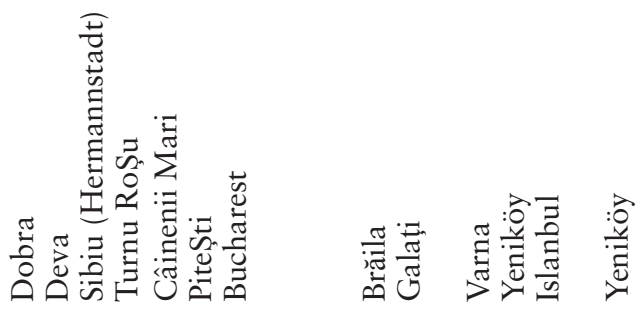

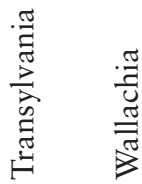

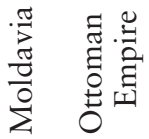




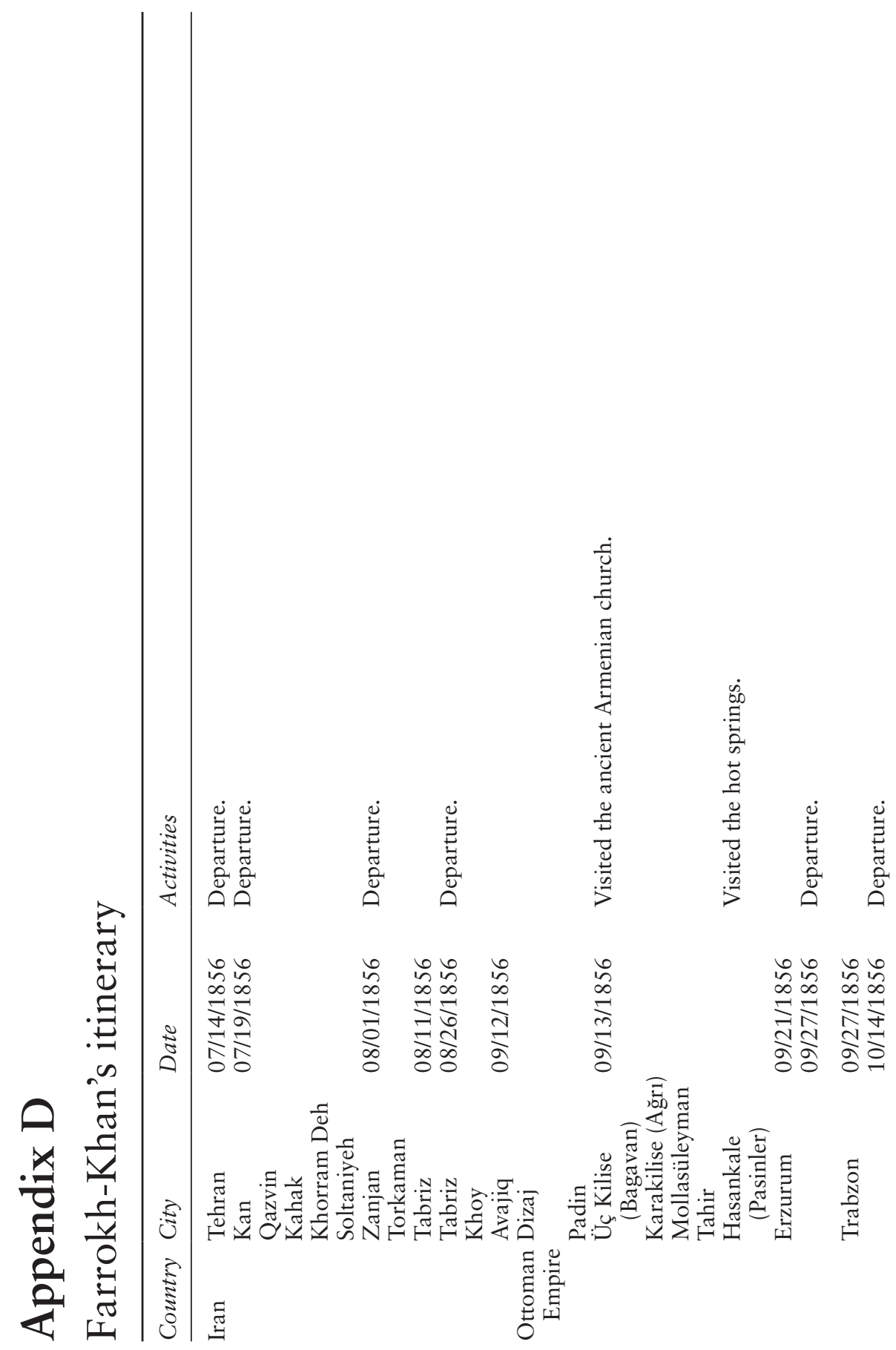



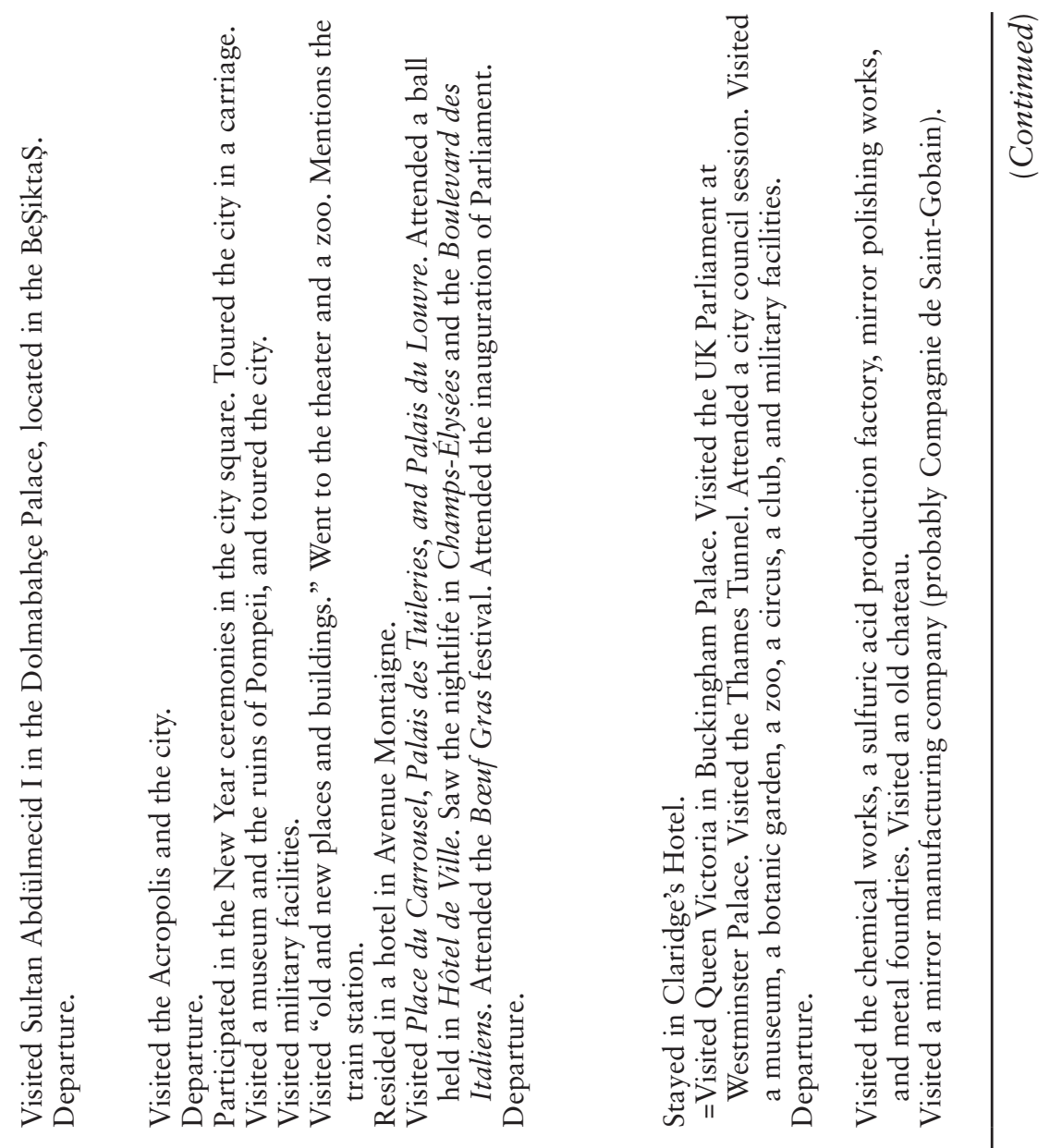

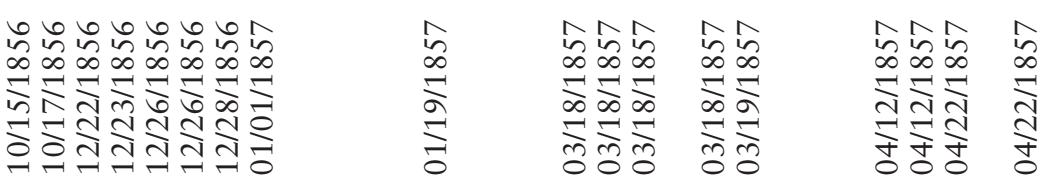

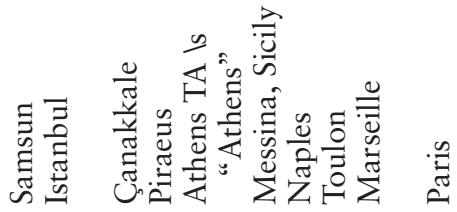

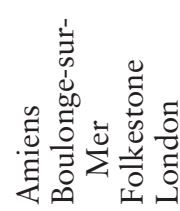

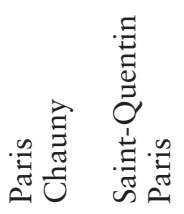

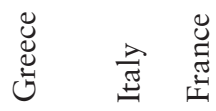

్ㅗㅇ

苋 


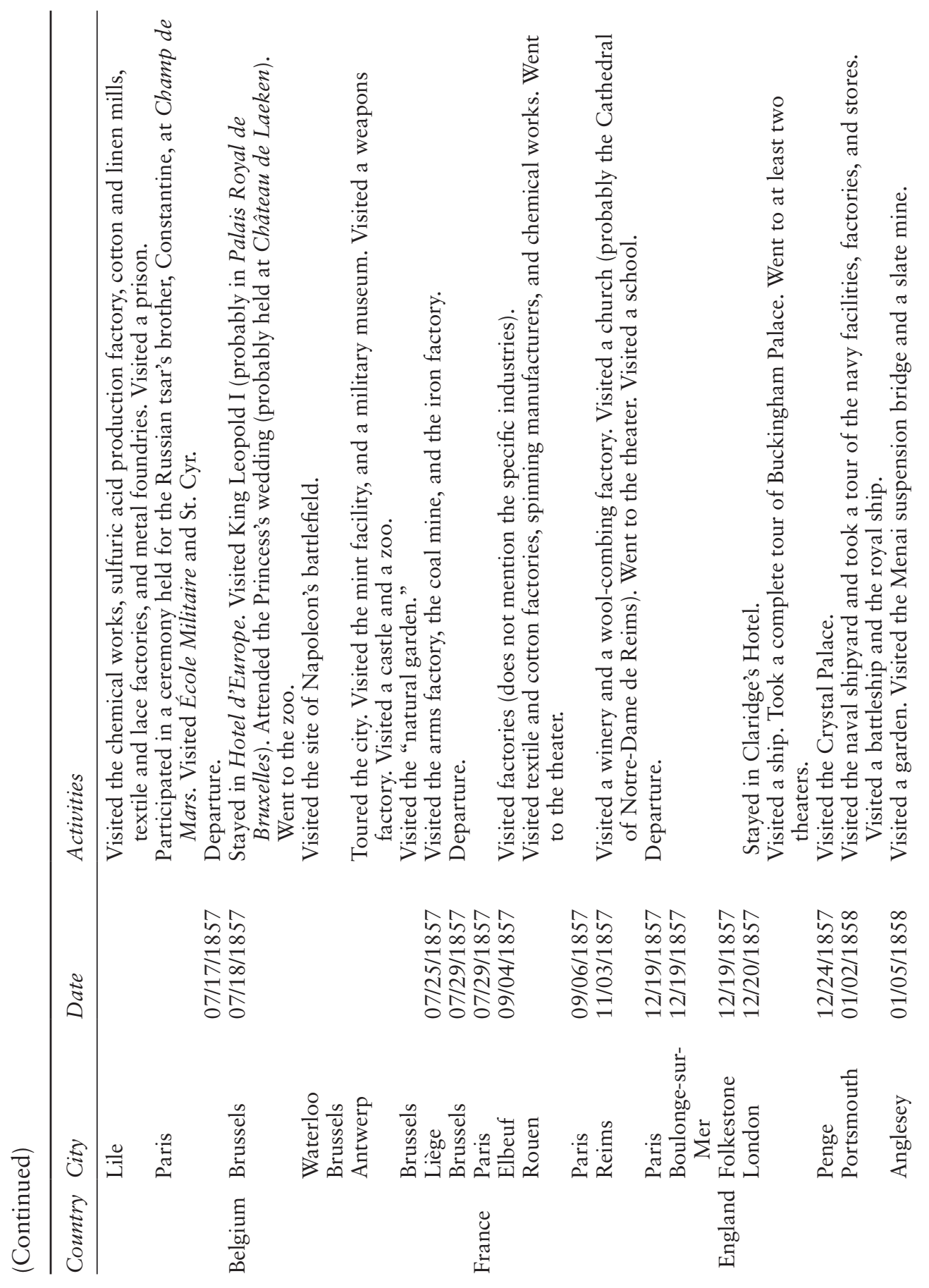



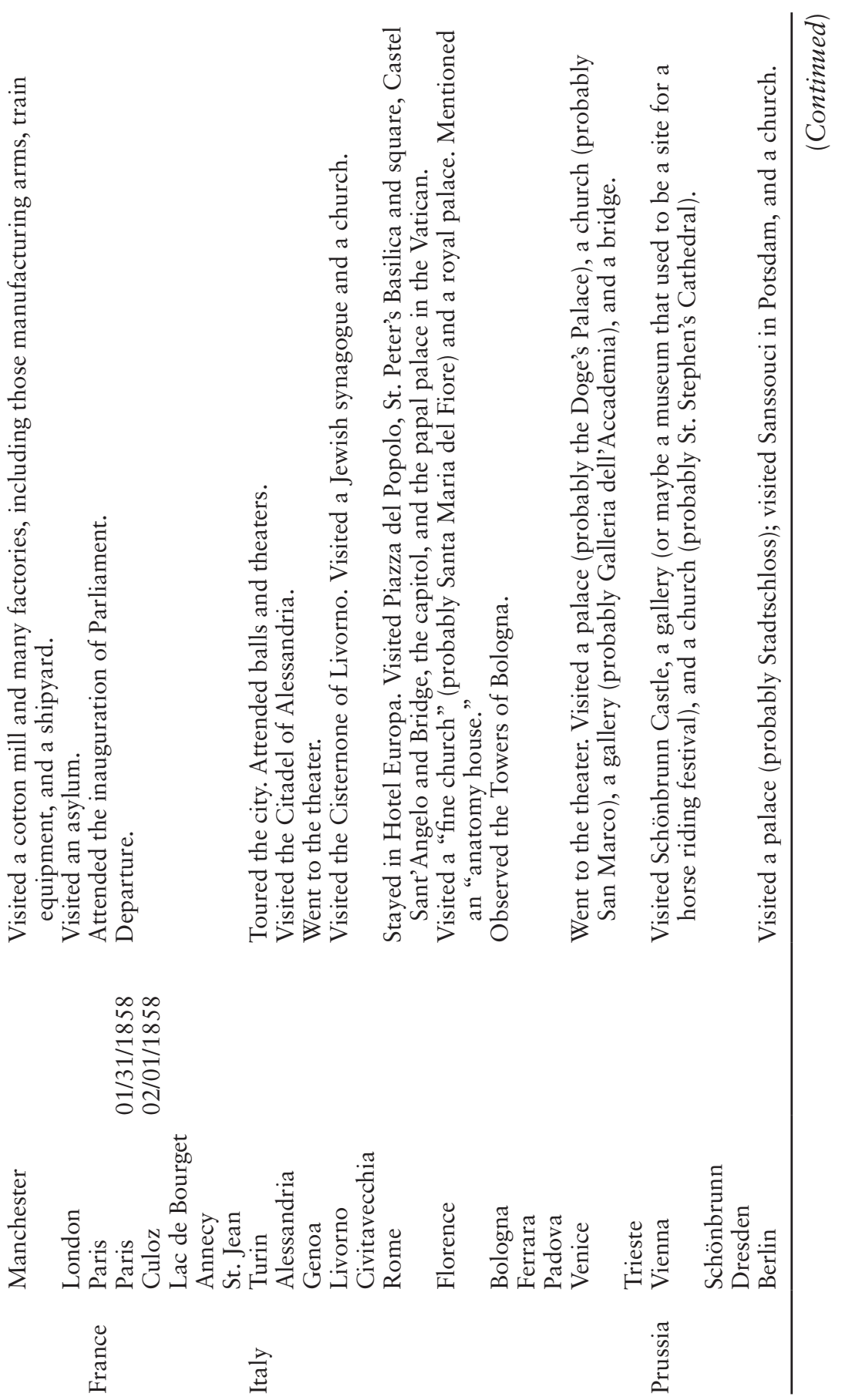


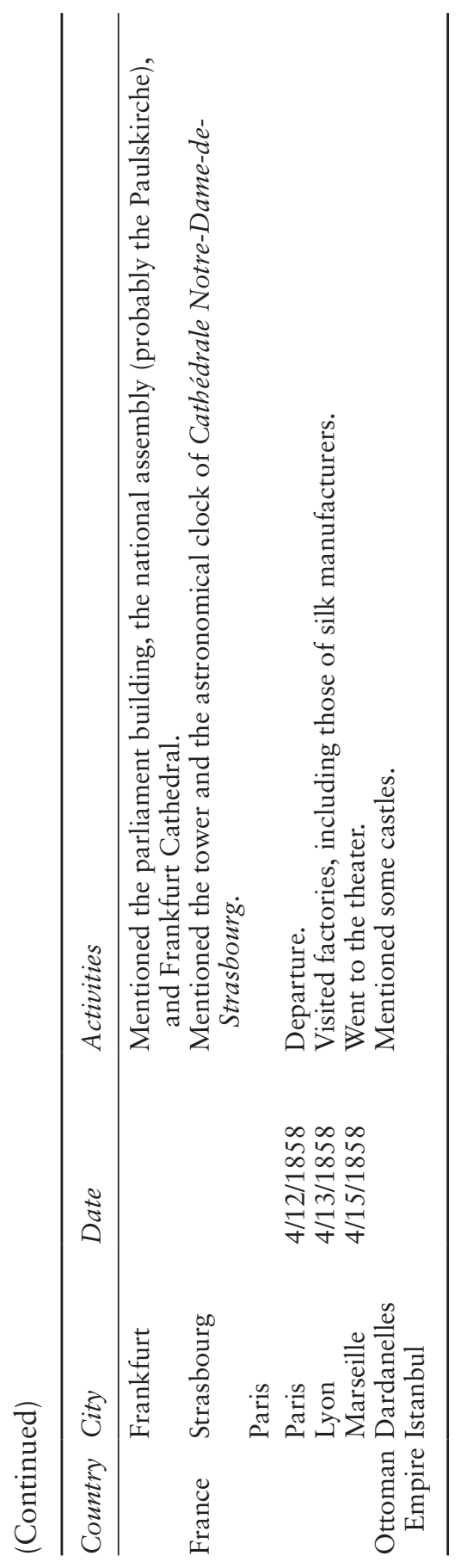




\section{Glossary}

'Ali عالى: perfect

'Am ('Omum) (عام (عموم: public

'Azim عظيم: large

Abad آباد: thriving

Andaruni اندرونى: the private section of a building

Arasteh آراسته: adorned, organized

Ba-nezam بانظام: orderly

Ba-safa باصفام: delightful

Ba-tartib باترتيب: organized

Badgir بادئي: wind tower, a structure that passively channels exterior airflow into the building

Bagh باغ: garden

Behesht بهشت: heaven

Biruni بيرونى: the public area in a building

Charbagh جارباغ: quadrilateral order of the Persian garden

Divankhaneh ديوانخانه: House of Justice

Entezam انظظام: order

Enzebat انضباط: discipline and order

Estehkam استحكام: strength, stability

Eyd عيد: Islamic and Persian feast

Farangestan / Farang فرنغ /فرنعستان: West

Farangi فرنغى: Westerner

Farsakh فرسخ : فرنخ: historical Iranian unit of distance comparable to the European league

Ghavi قوى: strong

Gholamgardesh غلامكَرش: a corridor surrounding the courtyard or the talar in pre-modern Persian architecture

Hamvar هموار: smooth, even

Heyrat حيرت: astonishment, wonder

Huri حورى: beautiful maidens who, as Islam teaches, attend believers in the heaven

Kabutar-khaneh كبوترخانه: pigeon tower, used for collecting pigeon dung Kharab خراب: ruined, broken 


\section{Glossary}

Kucheh-bagh كوجه باغ: a linear orchard, aligned along the sides of an alleyway, that follows the principles of charbagh

Mashruteh مشروطه: the constitutional movement of 1906 in Iran

Me'jar معجر: baluster

Me'mar معمار: architect

Minakari ميناكارى: vitreous enamel

Mohkam محكم : sturdy

Monabbatkari منبت كارى: wood carving

Mostahkam مستحكم: firm

Nahamvar ناهموري: rough, uneven

Nazm نظ: order

Qanat قنات: subterranean water-supply system that extracts, transports, and distributes groundwater through underground irrigation canals

Pak ياك: clean

Pakizeh بإكيزه: clean

Pirasteh بيراسته: pristine

Rafi' رفيع: high, lofty

Rezvan رضوان: paradise

Ruzaneh روزانه: literally meaning "daily," referring to a diary

Safarnameh سفرنامه: travel diary

Saman سنامان: order

Santur سنتون: Iranian hammered dulcimer

Savad-e shahr سواد شهر: cityscape, skyline

Shahanshah شاهنشاه: king of kings

Shah-Neshin شناه نشين literally meaning "the king's throne," the most important part of a space in Persian traditional buildings, designated for the guests or the elderly members of the family

Shahi شاهی: Iran's historic unit of currency

Shahr-e Farang شهرفرنغ : شاهر: a stereoscope that showed images of Farangestan cities

Shari'a شريعة: religious law

Shirin شيرين :شeet

Soffeh صفف: a semi-enclosed space that is walled on three sides but open toward the garden

Tafarrojgah تفرجگاه: place of recreation

Tajaddod تجداء: Iran's experience of modernity during the late 19th and early 20th centuries

Talar تالار: a form of soffeh within a house, used during summer

Tartib ترتيب: order

Tekyeh تكيه: an often open space that serves as a venue for religious mourning rituals in Iran

Vasi' وسيع: extensive, large

Waqf وقف: an Islamic endowment of property to be used for a charitable or religious purpose

Yakhchal يخجال: a structure that produces and store ice 
Yengeh donya ينحه دنيا: the New World, America Zakhim ضخيم: thick

Zar' ذنرع: cubit, a unit of length almost equal to a meter Zendeh زند: alive, lively 


\section{Bibliography}

Adamiyat, Fereydoun. Andisheh-Ye Taraqqi Va Hokumat-e Qanun, Asr-e Sepahsalar [the Idea of Progress and the Rule of Law in Sepahsalar's Era]. 1st ed. Tehran: Entesharat-e Kharazmi, 1972.

- Fekr-e Azadi Va Moqaddameh-Ye Nehzat-e Mashrutiyyat [the Idea of Freedom and Introduction to the Constitutional Revolution]. Selseleh Ketabhay-e Tarikhi. Tehran: Entesharat-e Sokhan, 1961.

Afshar, Iraj. "Bahsi Dar Asnad-e Marbut Beh Farrokh Khan [Discussion About Documents Related to Farrokh Khan]." In Makbzan Al-Vaqayi: Safarnameh-Ye Farrokh Khan-e Aminoddowleh [Aminoddowleh's Travelogue], edited by F. Ghaffari and Majmu'eh Safarnamehha-Ye Irani, 586. Tehran: Asatir, 1994.

Afshar, Mostafa. Safarnameh-Ye Khosrow Mirza Beh Sanpeterzburg [Khosrow Mir$z a$ 's Travel to Saint Petersburg]. Tehran: Ketabkhaneh-ye Mostowfi, 1970.

al-Azm, Sadik Jalal. "Orientalism and Orientalism in Reverse." Khamsin, no. 8 (1981): 5-26.

Al-e Ahmad, Jalal. Plagued by the West [Gharbzadegi]. Modern Persian Literature Series. Delmor, NY: Center for Iranian Studies, Columbia University, 1982.

Alexander, Christopher, Sara Ishikawa, and Murray Silverstein. A Pattern Language: Towns, Buildings, Construction. New York: Oxford University Press, 1977.

Alinejad, Sirus. "Modernite Bayad Az Darun-e Jame'eh Zohur Konad [Modernity Should Be Indigenous to the Society]." http://www.bbc.co.uk/persian/arts/ story/2005/04/050420_pm-cy-behnam.shtml.

Amanat, Abbas. "Constitutional Revolution: Intellectual Background." In Iranica, edited by Ehsan Yarshater, 163-176. New York: Bibliotheca Persica Press, 1992.

—. "Hajji Baba of Ispahan." In Iranica, edited by Ehsan Yarshater, 561-568. New York: Columbia University, 2003.

Aminoddowleh, Farrokh-Khan. Makbzan Al-Vaqayi: Safarnameh-Ye Farrokh Khan-e Aminoddowleh [Aminoddowleh's Travelogue]. Edited by Majmu'eh Safarnameha-Ye Irani. 2nd ed. Tehran: Asatir, 1994.

Avery, Peter. "Ouseley, Gore." In Iranica, edited by Ehsan Yarshater. iranicaonline. org, 2004.

Ayati, Abdolhosein. Atashkadeh-Ye Yazdan. Yazd: Golbahar, 1938.

Berman, Marshall. All That Is Solid Melts into Air: The Experience of Modernity. New York, NY: Viking Penguin, 1988.

Bhabha, Homi. "Of Mimicry and Man: The Ambivalence of Colonial Discourse." Discipleship: A Special Issue on Psychoanalysis 28 (1848): 8. 
Boroujerdi, Mehrzad. Iranian Intellectuals and the West: The Tormented Triumph of Nativism. Mohammed El-Hindi Series on Arab Culture and Islamic Civilization. 1st ed. Syracuse: Syracuse University Press, 1996.

. " 'The West' in the Eyes of the Iranian Intellectuals of the Interwar Years (1919-1939)." Comparative Studies of South Asia, Africa and the Middle East 26, no. 3 (2006): 391-401.

British Library. "Papers of the Marquis Wellesley."

Buruma, Ian, and Avishai Margalit. Occidentalism: The West in the Eyes of Its Enemies. New York: Penguin Press, 2004.

Calmard, Jean. "Hosayniya." In Encyclopedia Iranica, edited by Ehsan Yarshater, 517-518. New York: Columbia University Press, 2004.

Carrier, James G. Occidentalism: Images of the West. Oxford: Oxford University Press, 1995.

Chen, Xiaomei. “Occidentalism as Counterdiscourse: 'He Shang' in Post-Mao China." Critical Inquiry 18, no. 4 (Sum 1992): 686-712.

- Occidentalism: A Theory of Counter-Discourse in Post-Mao China. New York: Oxford University Press, 1995.

Cloake, Margaret Morris. "Foreword and Footnotes." Translated by Margaret Morris Cloake. In A Persian at the Court of King George: The Journal of Mirza Abul Hassan Khan. London: Barrie \& Jenkins Ltd, 1988, 7-12.

Curzon, George. Persia and the Persian Question. Second impression ed. Vol. 1, London: Longmans, Green, and Co., 1892. Texte imprimé.

Diba, Layla, and Maryam Ekhtiar, eds. Royal Persian Paintings: The Qajar Epoch, 1785-1925. London: I.B. Tauris, 1998.

Dubler, Cesar E. “Adja'ib.” In Encyclopedia of Islam, 203-204. Leiden: Brill.

Eastwick, Edward Backhouse. Journal of a Diplomate's Three Years' Residence in Persia. 2 vols. London: Smith, Elder and co., 1864.

Editorial. "Darolkhelafeh Tehran.” Vaghaye Ettefaghiyeh, December 121851.

Editorial. "Hamedan.” Vaghaye Ettefaghiyeh, July 61853.

el-Enany, Rasheed. Arab Representations of the Occident: East-West Encounters in Arabic Fiction. Culture and Civilization in the Middle East. London, New York: Routledge, 2006.

Engels, Friedrich. The Condition of the Working-Class in England in 1844. Stanford, Oxford, London: Stanford University Press Basil Blackwell and Allen and Unwin, 1958.

Eslami, Kambiz. “Ajudanbashi.” In Encycopedia of Islam, edited by Gudrun Krämer, Denis Matringe, John Nawas and Everett Rowson: Brill Online, 2014.

Etemadossaltaneh, Mohammad Hasan Khan. Mer'atolboldan Naseri [in Persian]. 4 vols. Vol. 3, Tehran: Asfar, 1985.

"Express from Paris." Times, February 51858.

Farmanfarmai Qajar, Asghar. "Footnotes." In Safarnameh-Ye Rezaqoli Mirza Navey-Ye Fath Ali Shah [the Travel Account of Rezaqoli Mirza, Fath Ali Shab's Grandson]. Tehran: Asatir, 1994.

Findley, Carter Vaughn. "An Ottoman Occidentalist in Europe: Ahmed Midhat Meets Madame Gulnar, 1889.” American Historical Review 103, no. 1 (Feb 1998): 15-49.

Floor, Willem. “Čāp.” In Iranica, edited by Ehsan Yarshater, 760-764. London and New York: Routledge \& Kegan Paul, 1990. 


\section{Bibliography}

"Fogg's Arabistan." The Saturday Review of Politics, Literature, Science and Art, 1876.

“Foreign Intelligence.” Times, March 141857.

Foucault, Michel. "Of Other Spaces." Diacritics-a Review of Contemporary Criticism 16, no. 1 (Spr 1986): 22-27.

Fraser, James Baillie. "Paper Modernity? Notes on an Iranian Industrial Tour, 1818." Iran 46 (2008): 277-284.

- Narrative of a Journey into Khorasan, in the Years 1821 and 1822 Including Some Account of the Countries to the North-East of Persia; with Remarks Upon the National Character, Government, and Resources of That Kingdom. London: Longman Hurst Rees Orme Brown and Green, 1825.

- Narrative of the Residence of the Persian Princes in London, in 1835 and 1836. The Middle East Collection. New York: Arno Press, 1973.

Gaffary, Farrokh. "Evolution of Rituals and Theater in Iran." Iranian Studies 17, no. 4 (Autumn, 1984): 28.

Ghanoonparvar, M. R. In a Persian Mirror: Images of the West and Westerners in Iranian Fiction. 1st ed. Austin: University of Texas Press, 1993.

Gibson, James J. The Senses Considered as Perceptual Systems. Boston: Houghton Mifflin, 1966.

Gray, Basil. Persian Painting. London: E. Benn, 1930.

Green, Nile. The Love of Strangers: What Six Muslim Students Learned in Jane Austen's London. Princeton, NJ: Princeton University Press, 2015.

Grigor, Talinn. “Orient Oder Rome? Qajar 'Aryan' Architecture and Strzygowski’s Art History.” Art Bulletin LXXXIX, no. 3 (2007): 28.

Gurney, John and Negin Nabavi. "Dār Al-Fonūn.” Encyclopcedia Iranica, edited by Ehsan Yarshater. Vol. VI. New York: Bibliotheca Persica Press, 1993, 662-668.

Habibi, Mohsen. Az Shar Ta Shahr. 4th ed. Tehran: University of Tehran, 2003.

Habibi, Mohsen, and Zahra Ahari. Sharh-e Jarianhai-e Fekri-e Memari Va Shahrsazi-e Dar Iran-e Moaser Ba Takid Bar Dorei-e Zamani-e 1357 Ta 1383 [Theoretical Movements in Contemporary Architecture and Urban Planning in Iran from 1972 to 2004]. Daftar-e Pajhoheshhai-e Farhangi (Cultural Research Bureau), 2007.

Hafez. The Poems of Hafez. Translated by Reza Ordoubadian. Bethesda, MD: Ibex Publishers, 2006.

Hafez. "Poetry of Hafiz Translated by Shahriar Shahriari." http://www.hafizonlove. com/divan/06/254.htm.

Hanafi, Hasan. Muqaddimah Fi Ilm Al-Istighrab. al-Tabah 1st ed. Bayrut: al-Muassasah al-Jamiyah lil-Dirasat wa-al-Nashr wa-al-Tawzi, 1992.

Holmes, William Richard. Sketches on the Shores of the Caspian: Descriptive and Pictorial. London: R. Bentley, 1845.

Ilchi, Abolhasan. Heyratnameh: Safarnameh-Ye Mirza Aolhasan Khan-e Ilchi Beh Landan [Wonderlogue: The Accounts of Ambassador Abolhasan Khan's Travel to London]. 1st ed. Tehran: Moasseseh-ye Khadamat-e Farhangi-ye Rasa, 1986.

- A Persian at the Court of King George: The Journal of Mirza Abul Hassan Khan. Translated by Margaret Morris Cloake. London: Barrie \& Jenkins Ltd, 1988.

- Safarnameh-Ye Mirza Abolhasan Khan Shirazi Beh Rusiyeh: Dalil as-Sufara [Abolhasan Khan's Travel Memoir of Russia]. Tehran: Donya-ye Ketab, 1984. 
Jadid Bonab, Ali. "Jostari Dar Farhang Va Tamaddon-e Eslami [an Introduction to Islamic Culture and Civilization].” Boshra no. 55 (2007): 38-43.

Javadi, Hasan. “Abu'l-Ḥasan Khan Īlčǐ: Persian Diplomat, B. 1190/1776 in Šīāāz.” In Encyclopadia Iranica, edited by Ehsan Yarshater, 308-310. New York: Columbia University Press, 1983.

Katouzian, Homa. "The Short-Term Society: A Study in the Problems of Long-Term Political and Economic Development in Iran." Middle Eastern Studies 40, no. 1 (Jan 2004): 1-22.

Kayat, Assaad Y. A Voice from Lebanon with the Life and Travels of Assaad Y. Kayat. London: Madden \& Co., 1847. Texto impreso.

Kipling, Rudyard. The Ballad of East and West. New York: Alex Grosset, 1889.

Koolhaas, Rem. "Bigness and the Problem of Large." In $S, M, L, X l$, edited by Rem Koolhaas and Bruce Man, 494-516. New York: Monacelli Press, 1995.

Kracauer, Siegfried, and Thomas Y. Levin. The Mass Ornament: Weimar Essays. Cambridge, MA: Harvard University Press, 1995.

Lacan, Jacques, and Bruce Fink. Ecrits: The First Complete Edition in English. New York: W.W. Norton \& Co., 2006.

Lamb, Charles. The Letters of Charles Lamb. Vol. II, London: Dent and Methuen, 1935.

Leask, Nigel. Curiosity and the Aesthetics of Travel Writing, 1770-1840: 'From an Antique Land'. Oxford, New York: Oxford University Press, 2002.

"Letter from the Persion Envoy, Mirza Abul Hassan." The Morning Post, May 29 1810.

Lewis, Bernard. The Muslim Discovery of Europe. New York: W.W. Norton, 2001.

Loos, Adolf. Ornament and Crime: Selected Essays. Studies in Austrian Literature, Culture, and Thought Translation Series. Riverside, CA: Ariadne Press, 1998.

Lynch, Kevin. The Image of the City. Publications of the Joint Center for Urban Studies. Cambridge, MA: Technology Press, 1960.

Marjani, Mohammad-Reza, and Behzadi Nasrin. “Mashgh-e Shahaneh: Moraghgha'at-e Naghghashi Naseraddin Shah-e Ghajar Dar Ketabkhaneh-Ye Saltanati-Ye Sabegh [Royal Sketches: Naseraddin Shah's Drawings]." Tarikh-e Mo'aser-e Iran no. 60 (2012): 269-332.

"Meerza Abul Hassan.-No. Ii." The Penny Magazine of the Society for the Diffusion of Useful Knowledge, October 25 1834, 2.

"Memoirs of the Persian Ambassador." La Belle Assemble: Or Court and Fashionable Magazine, June 1819, 2.

Milani, Abbas. Lost Wisdom: Rethinking Modernity in Iran. 1st ed. Washington, DC: Mage Publishers, 2004.

“Ministerial Banquet at the Mansion-House." Times, March 211857.

Minto, Gilbert Elliot. Lord Minto in India: Life and Letters of Gilbert Elliot, First Earl of Minto, from 1807 to 1814. London: John Murray, 1880.

Mirsepassi, Ali. Intellectual Discourse and the Politics of Modernization: Negotiating Modernity in Iran. Cambridge Cultural Social Studies. Cambridge, New York: Cambridge University Press, 2000.

Mitchell, Timothy. "The World as Exhibition." Comparative Studies in Society and History 31, no. 2 (1989), 217-236.

Molavi, Afshin. The Soul of Iran: A Nation's Journey to Freedom. New York: W. W. Norton, 2005. 


\section{Bibliography}

Momtahenoddowleh, Mahdi Khan. Khaterat-e Momtahenoddowleh: ZendegiNameh-e Mirza Mahdi Khan Momtahenoddowleh Shaqaqi. Tehran: Amir Kabir, 1974.

Morier, James Justinian. The Adventures of Hajii Baba, of Ispahan. London: R. Bentley, 1851.

—. "Extraordinary Particulars in the Life of Mirza Abul Hassan." La Belle Assemble: Or Court and Fashion Magazine, December 1811.

- A Journey through Persia, Armenia, and Asia Minor, to Constantinople, in the Years 1808 and 1809: In Which Is Included, Some Account of the Proceedings of His Majesty's Mission, under Sir Harford Jones . . To the Court of the King of Persia. London: Printed for Longman, Hurst, Rees, Orme, and Brown . . 1812.

. "The Mirza Abul Hassan." In The Adventurer of the 19th Century, Issues 1-37, 298-301. London: Knight and Lacey, 1823.

- A Second Journey through Persia, Armenia, and Asia Minor, to Constantinople, between the Years 1810 and 1816: With a Journal of the Voyage by the Brazils and Bombay to the Persian Gulf: Together with an Account of the Proceedings of His Majesty's Embassy under His Excellency Sir Gore Ouseley. London: Longman, Hurst, Rees, Orme, and Brown, 1818.

Morsalvand, Hasan. "Introduction." In Heyratnameh: Safarnameh-Ye Mirza Aolhasan Khan-e Ilchi Beh Landan [Wonderlogue: The Accounts of Ambassador Abolhasan Khan's Travel to London]. Edited by Hasan Morsalvand, Tehran: Moasseseh-ye Khadamat-e Farhangi-ye Rasa, 1986, 11-44.

Moshiri, Mohammad. Sharh-e Mamuriyat-e Ajudanbashi [Ajudanbashi's Mission], Tehran: Ashrafi, 1968.

Mozaffaraddin Shah. Dovvomin Safarnameh-Ye Moz? Affaraddin Shah Be Farang [Mozaffaradding Shab's Second Trip to Farang] [in Persian.]. Manabe'-e TarikhiYe Moaser-e Iran. Edited by Fakhrol Molk. 1st ed. Tehran: Kavish, 1983.

- Safarnameh-Ye Sevvom-e Mozaffaraddin Shan Be Farang [Mozaffaraddin Shab's Third Trip to Farang] [in Persian.]. Edited by Mohammad Naser Nasiri Moghaddam. Terhan: Markaz-e Asnad Majles, 2011.

Musset, Alfred de, Marie Agathe Clarke, Raoul Pellissier, Mary Helena Dey, and Kendall Warren. The Complete Writings of Alfred De Musset. 10 vols. New York: E.C. Hill Co., 1905.

Nanquette, Laetitia. Orientalism Versus Occidentalism: Literary and Cultural Imaging between France and Iran since the Islamic Revolution. International Library of Cultural Studies. 1 vols. London: I.B. Tauris, 2012.

Naseraddin Shah. Ruznameh-Ye Khaterat-e Naseraddin Shah Dar Safar-e Avvale Farangestan. Edited by Fatemeh Ghaziha. Tehran: Sazman-e Asnad-e Melli-ye Iran, 1998.

- Ruznameh-Ye Khaterat-e Naseraddin Shah Dar Safar-e Dovvom-e Farangestan. Edited by Fatemeh Ghaziha Tehran: Sazman-e Asnad-e Melli-ye Iran, 2000.

—. Ruznameh-Ye Khaterat-e Naseraddin Shan Dar Safar-e Sevvom-e Farangestan. Edited by Mohammad Esma'il Rezvani Tehran: Sazman-e Asnad-e Melli-ye Iran, 1990.

Necipoğlu, Gülru. "Framing the Gaze in Ottoman, Safavid, and Mughal Palaces." Ars Orientalis 23 (1993): 39.

Ouseley, William. Travels in Various Countries of the East: More Particularly Persia. 2 vols. Vol. I, London: Rodwell and Martin, 1819. 
Parvin, Nassereddin. “Tajaddod.” In Iranica, edited by Ehsan Yarshater. New York, Bibliotheca Persica Press, 2004, 119-120.

"The Persian Ambassador." The Morning Herald, June 271810.

The Persian Ambassador by the Town Crier.” The Statesman, January 251810.

Price, William, and Mirza Saleh Shirazi. A Grammar of the Three Principal Oriental Languages, Hindoostanee, Persian, and Arabic, on a Plan Entirely New, to Which Is Added, a Set of Persian Dialogues. London: Kingsbury, Parbury, and Allen, 1823.

Rezaqoli-Mirza. Journal of a Residence in England, and of a Journey from and to Syria, of Their Royal Highnesses Reeza Koolee Meerza, Najaf Koolee Meerza, and Taymoor Meerza, of Persia, to Which Are Prefixed Some Particulars Respecting Modern Persia, and the Death of the Late Shah. Translated by As'ad Yakub Khayyat. London, Westmead: W. Tyler, Gregg Inter., 1839.

- Safarnameh-Ye Rezaqoli Mirza Navey-Ye Fath Ali Shah [the Travel Account of Rezaqoli Mirza, Fath Ali Shah's Grandson]. Majmueh Safarnameha-Ye Irani. Edited by Asghar Farmanfarmai Qajar. 3rd ed. Tehran: Asatir, 1994.

Sa'adatnuri, Hosein. "Abutaleb Farrokh Khan-e Aminoddowleh Ghaffari." Vahid Monthly 3, no. 5 (1966): 411-423.

Said, Edward. Orientalism. 1st Vintage Books ed. New York: Vintage Books, 1979.

Salmasi, Katia. "Sayeh-Ei Dar Akkasi-Ye Iran [a Shadow in Iranian Photography]." Bokhara, no. 35 (2004): 10.

Shabazi, Abdollah. "Mir-Hossein Mousavi Anguneh Keh Man Shenakhtam: Beh Bahaneh-Ye Didar-e Akhiram Ba Mohandes Mousavi [Mir-Hossein Mousavi as I Knew Him].” In Yaddasht-ha-ye Parakandeh, 2009, http://www.shahbazi.org/ blog/Archive/8712.htm.

Sharabi, Hisham. Neopatriarchy: A Theory of Distorted Change in Arab Society. New York: Oxford University Press, 1988.

Sharifi, Naser. Cataloging of Persian Works Including Rules for Transliteration, Entry and Description. Chicago: American Library Association, 1959.

Shayegan, Darius. Cultural Schizophrenia: Islamic Societies Confronting the West. Modern Intellectual and Political History of the Middle East. 1st Syracuse University Press ed. Syracuse: Syracuse University Press, 1997.

Shirazi, Mirza Saleh. Majmueh Safarnameha-Ye Mirza Saleh Shirazi [Series of Travelogues by Mirza Saleh Shirazi]. Nashr-e Tarikh-e Iran. 1st ed. Tehran: Nashr-e Tarikh-e Iran, 1985.

Sohrabi, Naghmeh. Taken for Wonder: Nineteenth-Century Travel Accounts from Iran to Europe. New York: Oxford University Press, 2012.

Sullivan, Louis H. The Tall Office Building Artistically Considered. Minneapolis: University of Minnesota Press, 1922.

Tabatabai, Javad. Dibachahi Bar Nazariyah-I Inhitat-I Iran [an Introduction to the Theory of Decadence in Iran]. Andishah-I Siyasi 2. Chap-i. 1st ed. Tehran: Nigahi Muasir, 1380.

- Ta'ammoli Dar Bareh-Ye Iran: Maktab-e Tabriz [Tabriz School and the Foundations of Modernity] [in Persian.]. 1st ed. Tehran: Nashr-e Negah-e Mo'aser, 2006.

- Ta'ammoli Dar Bareh-Ye Iran: Nazariyyeh-Ye Hokumat-e Ghanun Dar Iran [Theory of Constitutional Governance in Iran] [in Persian.]. 2nd ed. Tehran: Intisharat-e Sotudeh, 2008. 


\section{Bibliography}

Taheri, Farrokh. "Doktor Jamshid Behnam Az Iranian Va Andiesheh-Ye Tajaddod Miguyad [Jamshid Behnam Discusses the Idea of Tajaddod in Iran].” http://www. shahrvand.com/archives/28924.

Tavakoli-Targhi, Mohamad. Refashioning Iran: Orientalism, Occidentalism, and Historiography. St. Antony's Series. Houndmills, Basingstoke, Hampshire, New York: Palgrave, 2001.

—. "Tajaddod-e Ruzmarreh Va Ampul-e Tadayyon [Everyday Modernity and Religious Inoculation].” Iran Nameh XXIV, no. 4 (2009): 37.

Thomas, Evan. "The Day That Changed America.” Newsweek, Dec 30 2001, 40-71.

Titley, Norah M. Persian Miniature Painting and Its Influence on the Art of Turkey and India: The British Library Collections. Austin: University of Texas Press, 1984.

Vahdat, Vahid. "Spatial Discrimination in Tehran's Modern Urban Planning 19061979." Journal of Planning History 12, no. 1 (2013): 49-62.

—. "A Study on Urban Development in Iran from 1925 to 1941, Case Study: Yazd [in Persian].” Journal of Honar-ha-ye-ziba no. 31 (2007): 5-14.

Vitruvius, Pollio. Vitruvius: The Ten Books on Architecture. New York: Dover Publications, 1960.

Woltering, Robbert. Occidentalisms: Images of the West in Egypt. Leiden: Leiden University, 2009.

- Occidentalisms in the Arab World: Ideology and Images of the West in the Egyptian Media. Library of Modern Middle East Studies. London: I.B.Tauris, 2011.

Wright, Denis. "Fraser James Baillie.” In Iranica, edited by Ehsan Yarshater, 192195. New York: Columbia University, 2000.

_. "Introduction." Translated by Margaret Morris Cloake. In A Persian at the Court of King George: The Journal of Mirza Abul Hassan Khan, 13-21. London: Barrie \& Jenkins Ltd, 1988.

Wulff, Hans E. “The Qanats of Iran.” Scientific American 218, no. 4 (1968): 9.

Zaka, Yahya. "Preface." In Majmueh Safarnameha-Ye Mirza Saleh Shirazi [Series of Travelogues by Mirza Saleh Shirazi], 488. Tehran: Nashr-e Tarikh-e Iran, 1985. 


\section{Index}

Abbas-dust 117-18

Abbas-Mirza (crown prince of Iran) 21

Abdülmecid (Ottoman Sultan) 53

About Elly 144-5

Academy Palace, Brussels 110-11

Acropolis, Athens 48, 109, 111

Adventures of Hajii Baba of Ispahan,

The (James Morier) 20-1, 137

Africa 58

Afshar, Mirza Hajibaba 7, 136-7

Ajudanbashi, Hoseyn Khan 7, 15, 136-8, 143

Akhbar-e vaqaiyyeh (Newspaper) 23

al-Aqsa Mosque, Jerusalem 52

Alborz 59

Alexander, Christopher 49

Alvand 59

America 27, 69, 70, 75

Aminoddowleh, Farrokh-Khan 7, $10,15,31-35,37-8,46-8,52-6$, $61-3,138,141$; on aesthetics and ornaments 114-16, 119; on architectural grandeur 109-10; on building structure 110-13; on centrality and procession 107-8; constructions 142; discussed streets 80-1; interest in America 69; as an object of gaze 66 ; on order and cleanness 94, 117, 119; on Pompeii 82-4; on public space 105-6; on space regulations 97 ; on streetlights 100-2; surveyed space 50; on urban typologies 93; visited Crystal Palace 87-8, 111

Amir Kabir 136-7

Antwerp 80, 129

Asheq-Esfahani (Persian poet) 29

Astley's Amphitheatre 47, 88

Atta, Mohammad 3

Austria 108-9
Baghdad 27, 138

Baha'i, Sheykh 82

Baltic Sea 56

Basra 15, 17

Bath 60, 65-6, 81, 96, 98, 110-11

Beechey, Sir William 18

Behistun 52

Beirut 30, 53, 56, 70, 81

Belgium 80, 91

Berman, Marshall 6

Bethlem Penitentiary, London 95

Bhabha, Homi 142

Black Friars Bridge, London 112

Bonaparte, Napoleon 24-5

Boulevard des Italiens, Paris 106

Brandenburgh House, London 109

Bristol 60

Britain 16, 31, 50, 69, 108, 112, 137

Brussels 84, 110

Bucharest 91

Buckingham House, London 62; see also Buckingham Palace

Buckingham Palace, London 119

Burdett, Sir Francis 103

Cádiz 30, 109

Cape Frio 70

Carlhian, Francis 38

Caspian Sea 144

Champ de Mars, Paris 48

Champs-Élysées, Paris 102

Château de Coucy, Picardy, France 111-12

Chelsea Royal Hospital, London 104, 109

Chiswick House, Chiswick, London 86

Civitavecchia 117

Crown Inn, Portsmouth 91

Crystal Palace 63-4, 87, 111

Curzon, George 137 
Damascus 52, 57, 89

Damavand 52, 59, 113

D’Arcy, Colonel Joseph 35

Dardanelles 53

Darolfonun 143

de Musset, Alfred 135

Devonport 60

Doré, Gustave 118, 120

East India Company 37, 65; library, 17,29

École Militaire, Paris 107, 109

Elgin, Lord 116

Engels, Friedrich 121

Enghien 65

England 15-16, 20-2, 24, 27, 30-1, $37,51-2,56,60,63-4,68-9$, $80,90,94,98-9,102-3,111-12$, 114-17, 119, 136-8, 141-2

Eram $85-7,89$

Erzurum 79

E’temadodowleh, Haji Ebrahim Khan 15

Europe 3-4, 6-8, 10, 15-17, 20-1, 26-7, 30-1, 33-8, 49, 51-8, 62, 66, 68-9, 71, 80, 83, 85, 89, 91, 93-5, 97, 101-2, 107-8, 112, 114-16, 120, 136-8, 142-3, 145

Exeter 24, 60, 92

Exeter Cathedral, Exeter 60

Farhadi, Asghar 1, 144

Farmanfarma, Hoseyn-Ali 27, 136-7

Farren, John William 57

Fars 136-7, 143

Fath-Ali Shah 16, 31, 136

Ferdowsi (Persian Poet) 29

Foucault, Michel 6,8

France 21, 35, 51, 69, 107, 109, 111

Fraser, James Baillie 27-31, 36-7, 49, 58-61, 81, 85, 90-1, 95, 109, 119, 140; on Farangestan 51; interacting with Iranian travelers 137-8; on the Iranian servants 141; on travelers as an object of Farangi gaze 65-8; visited Ilchi's house, 142

Freemasonry 27, 35-6, 38

Galata 90

Gardjola Garden, Malta 79

George III (king) 18-19, 68

Germany 21

Ghaffari, Farrokh 52

Ghanun-e Baladiyeh 93 gharbzadegi 9

Gibraltar 59, 64-5, 70, 90, 110-12

Gilan 31, 52, 86

Golestan, Treaty of 138

Grammar of Three Principle Oriental Languages 23

Great Exhibition, The 63-4, 87

Greenwich 84, 104, 141

Greenwich Hospital 84, 94, 104, 141

Hafez (Persian Poet) 29, 30, 89

Haussmann, Georges-Eugène 97

heterotopia 8-9

Holmes, William Richard 142

House of Commons, Westminster 117; see also Palace of Westminster

House of the Lords, Westminster 79; see also Palace of Westminster

House of the People, St. Petersburg 105

Hyde Park, London 18, 89

Hyderabad 27

Ilchi, Mirza Abolhasan Khan 7, 10, 15-21, 25, 29, 47, 51-2, 56-60, 90, 135-8; on architectural grandeur 108-9; on architectural materials 110-12; architectural vocabulary 79; on building structure 113; criticality 116-19, 121; on Farangestan 54; financial estimates 50; on freedom, 102-3; on gardens, parks, and natural landscape 84-6, 89; his house 142; his servants 141 ; impressed by the trompe l'oeuil effects 62 ; as an object of Farangi gaze 63-8; on order and cleanness 94-7; on ornament and art 114; souvenirs from Europe 35-7; on spatial segregation of social classes 104-7; on streetlights 100-1; on streets $80-1$; on urban services 98-9; on urban typologies 93; on water fountains 91; in Yengeh donya 70

Image of the City, The 78

India 15, 21, 37

Iran 1-10, 15-17, 20-3, 26-7, 29, 31, $33-5,37-8,47-8,51-5,63-4,68$, 70, 78, 80-3, 85-6, 89-90, 92-4, 97, 102-3, 105-8, 110, 114-16, $118-19,136-45$

Isfahan $26,82,115$

Istanbul 14, 25, 53, 56, 59, 70, 86, 95-6, 139, 141

Italy 34 
Izmir 54

İzmit 83

Kamaloddin Esma'il (Persian poet) 29

Karachi 117-18

Kashan 31, 80, 83, 142

Kashmir 18, 86

Kayat, Assad 27, 29, 31, 36, 65, 88; lost portions of the manuscript 14

Kensington Gardens, London 19, 81,105

Khiyabani, Sheikh Mohammad 138

Khosrow Mirza 7, 15, 136

King's College Chapel, Cambridge 113

Kolkata 17

Koolhaas, Rem 108

Kracauer, Siegfried 95

Kremlin, Moscow 50

Lacan, Jacques 65

Lala Garden, Yazd 106

Lamb, Charles 63

Lawrence, Thomas 18

Leopold I (king) 31

Liège 65, 91

London 17, 19, 24, 26, 29-30, 35, 49, 58-9, 64, 81, 83-92, 96-7, 99-100, 103-5, 107, 109-10, 112-13, 115, 117-20, 136-8, 140-1

London Opera House 88

Lynch, Kevin 78, 79

Lyon 97

Magdalen House 104

Mahmud II (Ottoman Sultan) 139

Malta 58, 70, 79, 110

Manchester 121

mashru'a 9

Mashruteh Movement 108, 139, 144

Masonic lodge see Freemasonry

mass ornament 95

Mecca 17, 52

Medina 17

Melk 108

Melk Abbey, Austria 108

Menai suspension bridge 113

mental map 78

Messina 55, 80

mimicry 68

miniature painting 5, 32, 48, 143

mirror stage 65

Mirza Etesamoddin 135

Mirza Reza 50

Mitchell, Timothy 67
Mohammad Shah 16, 27, 136, 143

Mohandes, Mirza Reza 143

Moira, Lord 36

Morier, James 16-18, 20-1, 58-9, 68, $70,86,95,137-8,141$

Moscow 24-5, 50, 80, 110

Mostowfi, Mirza Mas'ud 136

Mozdok 56

Mumbai 17

Murshidabad 17

Nakhchivan 56

Naples 55, 80, 93

Napoleon III 31, 97, 142

Naseraddin Shah 7, 34, 38, 49, 138,143

Naziri-Neyshaburi (Persian Poet) 29

Nuri, Mirza Agha Khan 33

Ottoman Empire 5, 53, 69, 90, 138-9

Ouseley, Sir Gore 17-19, 103, 137-8; research on Iran 23; at St. Paul's Cathedral 62

Ouseley, Sir William 62, 138; at St. Paul's Cathedral 62

Paris $31,35,37,48,69,84,88,97$, 100, 105

Partridge, John 28

Paxton, Joseph 87

Percy, R. P. 35

Persia see Iran

Perso-Russian war 5, 16, 111, 136

Peter and Paul Fortress, St. Petersburg 79

Peter the Great 19, 56, 105

Plymouth 60, 64, 68, 80, 110

Pompeii 54, 82-4

Portman Square, London 106

Portsmouth 91, 108

Price, William 23

Primrose Hill, London 140

Prussia 34

Pune 17

Qa'emmaqam, Abolghasem 31

Qa'emmaqam, Mirza-Bozorg 21

qanat 90

Quran 18, 29, 91, 101

Reza Shah 106

Rezaqoli Mirza 7, 10, 14-15, 27-31, 35-8, 51, 63, 107, 136-140; on architectural forms 79; on architectural 
grandeur 108-9; on architectural materials 110-11; on building structure 112-13; communication challenges and strategies 46-50; criticality 119-20; on Farangestan 53, 56; on Farangi freedom and equality 102 , 104; on Farangi wonders 57-8; on functional division of space, 92-3; on gardens 85-6; his servants 141 ; object of Farangi gaze 65-8; on order and regulation 95-6; on ornaments 115 ; paradisiacal depiction of Farangestan 88-9; on public space 106; "real and artificial" 60-1; remystifies Farangestan 62 ; rides an elevator 59 ; on streets 81 ; on urban services and infrastructure 98-100; on water fountains 90-1; on windows 83; on Yengeh Donya 69

\section{ribla 135}

Rio de Janeiro 70

Rochester 67

Royal Academy of London 26

Royal Arg (citadel) of Tehran 81

Royal Naval Hospital, Plymouth 60

Russia 5, 15, 19, 21, 24, 54-6, 69, 80, $110,136,138,140$

Sabat Garden, Yazd 106

Sa'di (Persian poet) 29, 109

Sadler's Wells Theatre, London 47 safarnameh 6-9, 23, 32, 38, 135, 138,143

Said, Edward 4, 5

Saif el-Mulk 33

Salisbury 60

Salisbury Cathedral, Salisbury 60

Sarabi, Hoseyn 31, 33-4, 50

Schönbrunn Palace, Vienna 63

Separation, A (Asghar Farhadi) 1

Sharabi, Hisham 4

Shatt al-Arab 52

Shayegan, Darius 1

Shiraz 80, 137

Shirazi, Mirza Ebrahim 29

Shirazi, Mirza Saleh 7, 10, 15, 21-7, $29,35-8$
Shushtar 15

Sievier, Robert William 22

Solomon 26, 101

Southwark Bridge, London 112-13

Spielberg, Steven 67

St. Paul's Cathedral 17, 50, 58, 60, 62, 79, 113, 115

St. Petersburg 16, 25, 52, 56, 62, 70, 79, 94, 96, 98, 105, 107, 110, 136

Street-Widening Act 81

St. Stephen's Chapel 117

Tabriz 23, 33, 50

tajaddod 8-10, 138-41, 144-5

Taq Kasra 52

Tbilisi 25, 56, 110

Tehran 22, 23, 38, 81, 97, 115, 137,142

Teymur Mirza 27-8, 30, 49

Thames 50, 62, 99, 113

Thames tunnel, London 110

Timcheh-ye Aminoddowleh 142

Vali, Najafqoli 27-30, 36, 65-7, 86, $95,100,115$

Vauxhall Bridge, London 112

Vauxhall Gardens, London 26, 60-1, 88, 101

Victoria (queen) 30-1

Vienna 63

Vilshofen 65

Waldegrave, William 19

Westminster, Hall 113

Westminster, Palace of 79 , 107, 117

Westminster Bridge, London 112

Willock, Sir Henry 85

Windsor Castle, Windsor 109

Winter Palace, St. Petersburg 107

Wren, Christopher 94, 104, 117

Yazd 2, 106, 137, 143

Yengeh donya 69-71

Zamzam, Well of 116 